
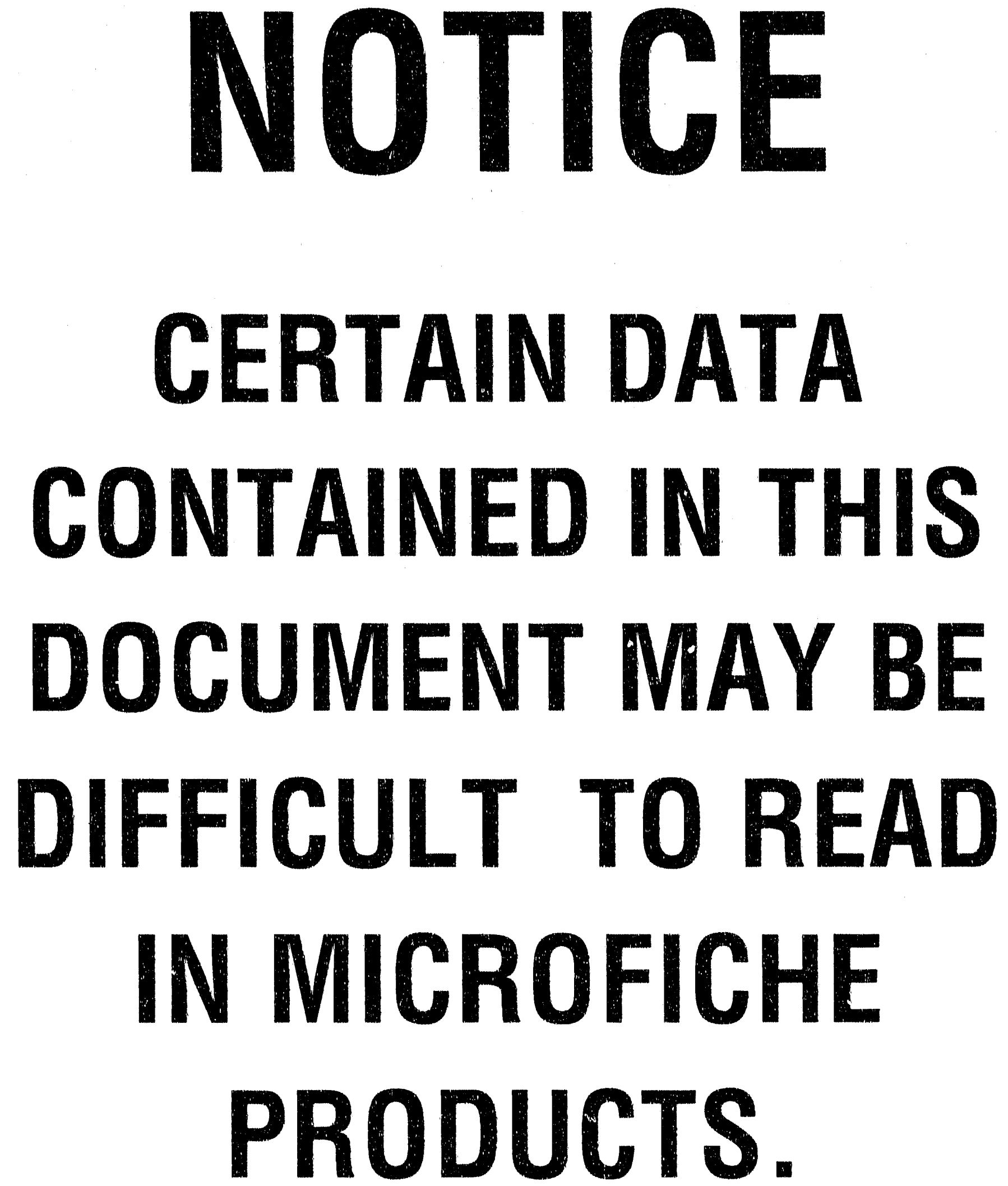


\section{Oxygen Electrode Reaction in Molten Carbonate Fuel Cells}

Principal Investigator: Anthony J. Appleby Co-Principal Investigator: Ralph E. White

September 15, 1987 -- September 14, 1990

Texas A\&M University

College Station, Texas 77843-3122

Grant No. DE-FG22-87PC79931

FINAL REPORT

Subrnitted to:

Dr. W.J. Huber

Project Manager

U.S. Department of Energy

Morgantown Energy Technology Center

P.O. Box 880

Morgantown, WV 26505

US/DOE Patent Clearance is not required prior to the publication of this document.

July 7, 1992 


\section{OXYGEN REDUCTION IN LITHIUM CARBONATE \\ MELT: DETERMINATION OF ELECTRODE \\ KINETIC AND MASS TRANSFER PARAMETERS}

\section{A Dissertation}

by

BHASKER B. DAVÉ

Submitted to the Office of Graduate Studies of

Texas Ad:M University

in partial fulfilment of the requiraments for the degree of

DOCTOR OF PHLOSOPHY'

Níl 199:

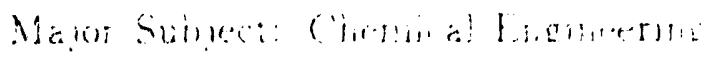

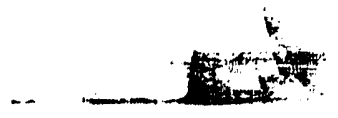


OX GEN REDUCTION IN LITHIA CARBONATE

MELT: DETERMINATION OF ELECTRODE

KINETIC AND MASS TRANSFER PARAMETERS

$\wedge$ Dissertation

by

BHASKER B. DAVÉ

Approved as to style and content by:

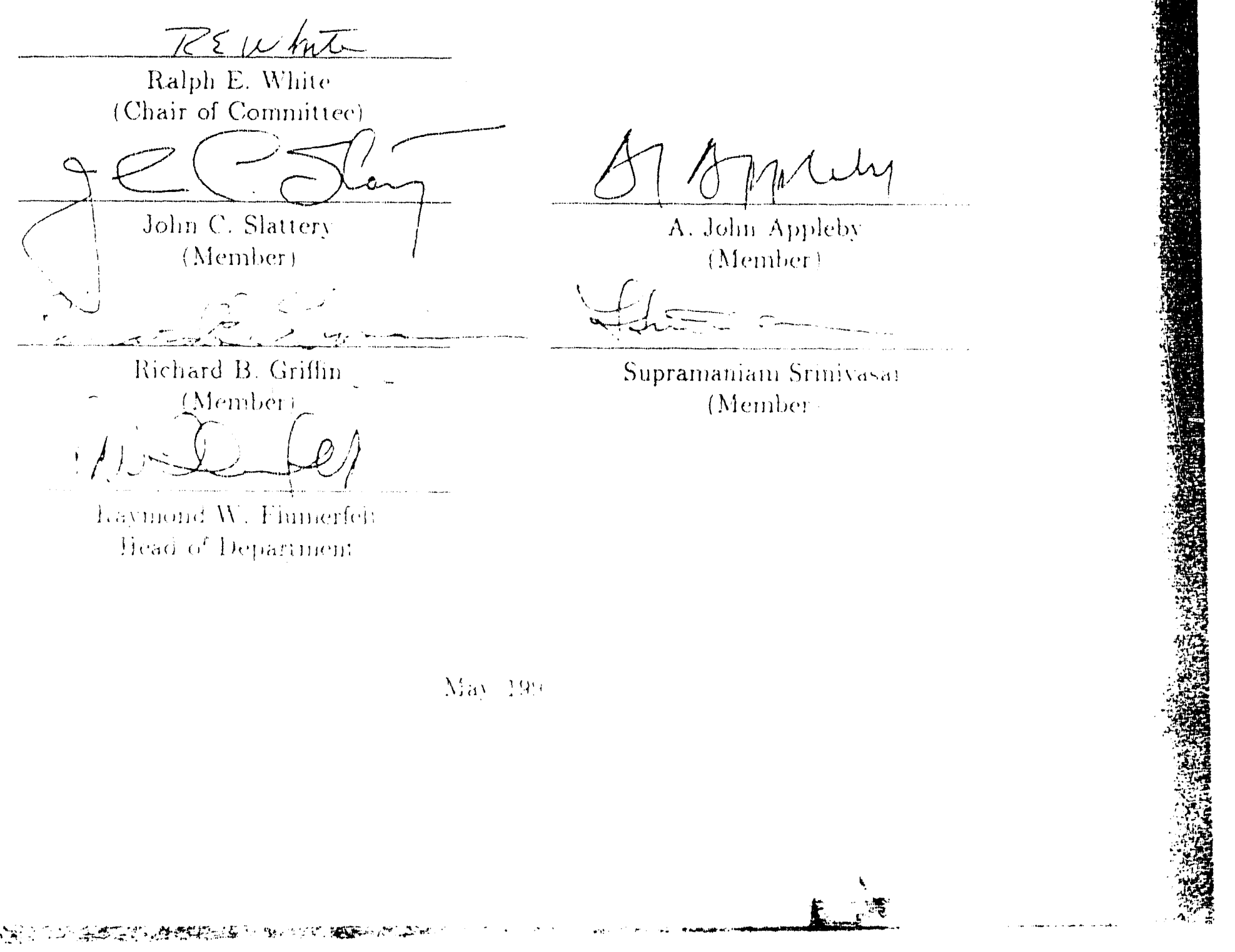




\title{
ABSTRACI
}

\author{
Oxygen Reducton in Lithum (arbonate Melt: Determination \\ of Elecrode Kinetic and Mass Transfer Parameters. (May 1991 ) \\ Bhaster B. Dave, B.Tech.. Liniversity of Madras: \\ M.S. Southern Illinois (Iniversity at Carbondale \\ Chair of Advisory Committee: Dr. Ralph E. White
}

Molten carbonate fuel cell system is a leading candidate for the utility power generation because of its high efficiency for fuel to AC power conversion. capability for an internal reforming. and a very low environmental impact. However. the performance of the molen cartonate fuel cell is limited by the oxygen reduction reaction and the cell life time is limiter by the stability of the cathode material. An elucidation of oxygen reduction reaction in molten alkali carbonate is essential because overpotenlial losses in the molten carbonate fuel cell are considerably greater at the oxygen cathode than at the fuel anode. The oxygen reduction reaction in molten alkali car. innate eiecirolye is complex and does not directly involve molecular oxygen. The wygen reduction mechanism strongly depends on the cations present in the melt.

Uagen reduction on a fulig immersed goic electrode in a lithium carbonale Meli was imestigated by elecirochemical impedance spectroscopy (EIS) and cyclic

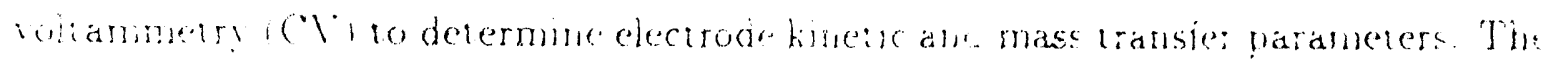

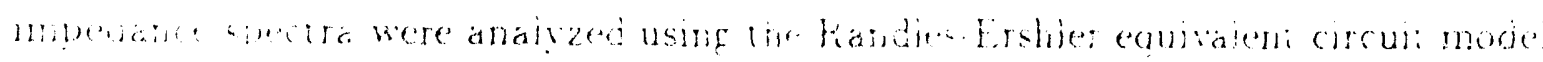

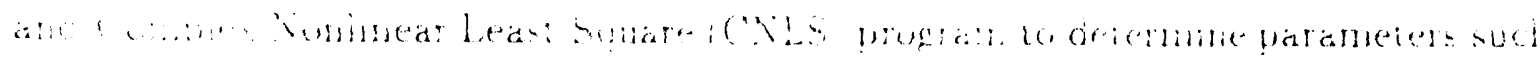

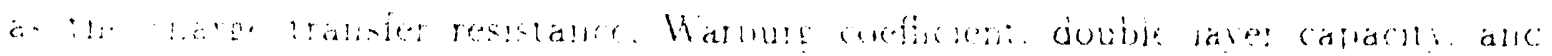

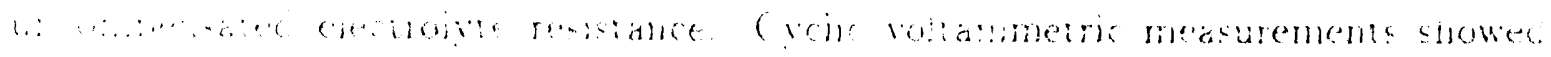

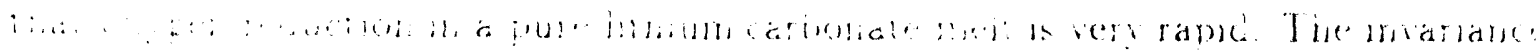

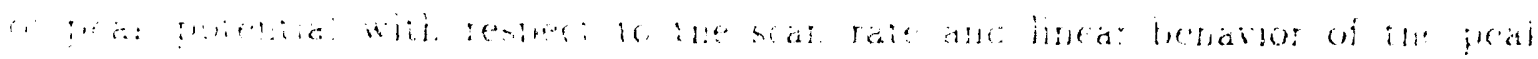

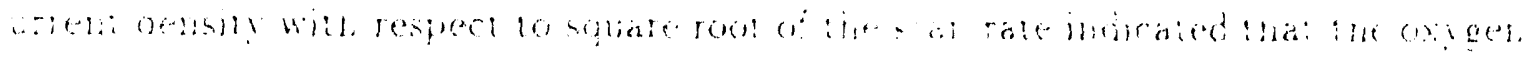

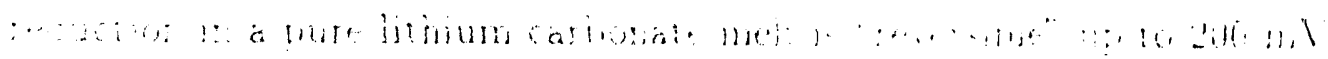

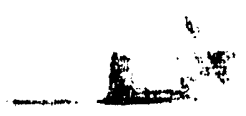




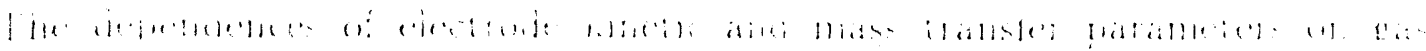

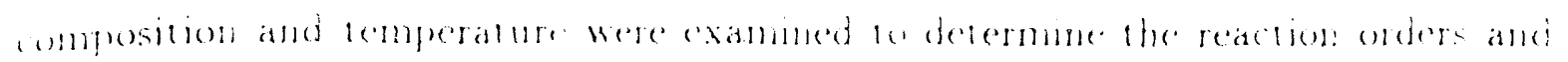
the actiation energies. The results showed tiat oxygen reduction in a pure lithim carbonate melt eccurs vid the peroxide mechanism. A mass transfer paraneter. $1)_{0}^{1 / 2}$ Co. estimated by the cyclic voltammetry concurred with that calculated by the EIS technique. The temperature dependence of the exchange current density and the product $\mathrm{D}_{\mathrm{O}}^{1 / 2} \mathrm{C}_{\mathrm{O}}$ were examined and the apparent activation energies were determined to be about 122 and $175 \mathrm{~kJ} / \mathrm{mol}$, respectively: 


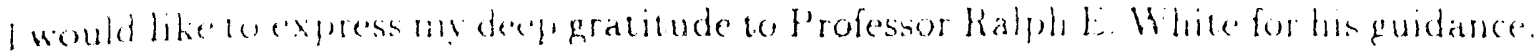
suppori and encourigemem through the period of this werk.

1 would lite to thank the L'. S. Department of Energy. Pittshurgh. PA. and the Electric Power Research Institute. Palo Alto. CA. for their financial support. and the Center for Electrochemical Systems and Hydrogen Research (CESHR) where tinis research was conducted. Thanks are due in particular to Dr. A. John Appleb! and Dr. Supramaniam Srinivasan of CESHR for their stimulating discussions and guidance; they also served as the advisory committee members. The design and fabrication of the experimental setup would not have been possible without the help from Drs. Mohammad A. Enayetullah, Prosper K. Adanuvor, and John Zhang. and Messrs. Arvind Parthasarthy and Omurtag Velev of Texas Ad:M University: Professor Edson Ticianelli of Instituto de Fisica Quimica de Sáo Carlos. Brazil. and Professor 1. Robert Selman and Dr. Karthik Ramaswami of Illinois Institute of Technology: ('hucago. IL.

Special thanks go to Professors John C. Slattery. Richard B. Griffin. and Edward l. Hazen for their suggestions while serving as advisory committee members. In addition. I would like to express my appreciation to all members. past and prosenti. of 'Tititi and of the (enter for Electrochemical Engineering for their support. Finall!. I would like to express my deepest gratitude to my wife Sandra. Whose encruragenem. anditce and chere have see ne through this arduous tast. 
To

My Mother, Triguna Davé

and

My Wife, Sandra Burke

For Their Unwavering Love, Patience, and Sacrifice

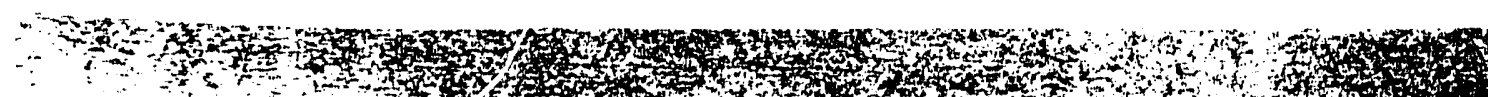


I INTROH)I: (ION

Types of Fuel Cells

Molten Carbonate Fuel Cell

Objeclives

Structure of Dissertation

11 OXYGEN ELECTRODE REACTIONS IN MOLTEN ALKALI CARBONATES

Introduction

Homogeneous Chemical Reactions Equilibria

Acid-Base Relationship in Molten Alkali Carbonates

Oxygen Reduction in Molten Alkali Carbonate Electroiytes

Conclusions.

II OXYGEN REDICTION IN LITHIUM CARBONATE MELT

Introduction

Oxigen Reduction hinetics in Lithium Carbonate Mel:

Experimental Setup

Cyclic Voltammetry.

Electrochemical Impedance Spectroscopy.

Conclusions

আ EFFECTS OH TEMPERATIRE

Intreciuction

Experimental

Electrochemica! Impedance Measuements and Andiv.

Cyclic loliammetr!

Concinsulens

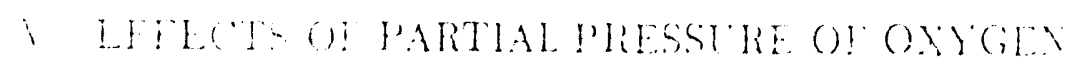

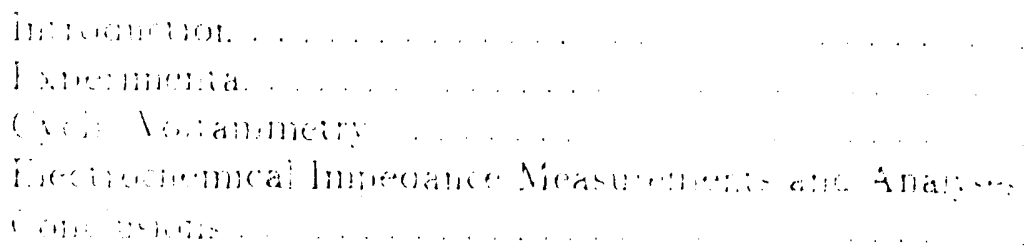


II EFFECTS OF PARTIAL PRESSLRE OF CARBON DIOAIIEE . . . . 9

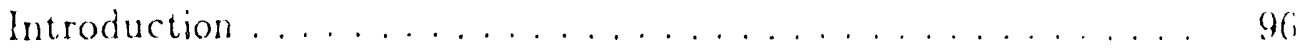

Experimental .......................... 99

Electrochemical Impedance Measurements and Analyses . . . . . 101

Cyclic Voltammetry . . . . . . . . . . . . . . . . . . . . . 116

Conclusions ......................... . . 130

VII CONCLUSIONS AND RECOMMENDATIONS . . . . . . . . . 132

Conclusions .......................... 132

Recommendations ....................... 134

LIST OF SYMBOLS ....................... 136

REFERENCES ........................ 138

APPENDIX

A DERIVATION OF ELECTRODE KINETIC EXPRESSIONS . . . . . . 144

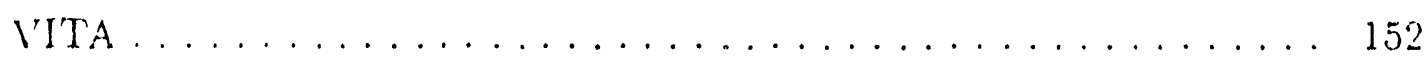

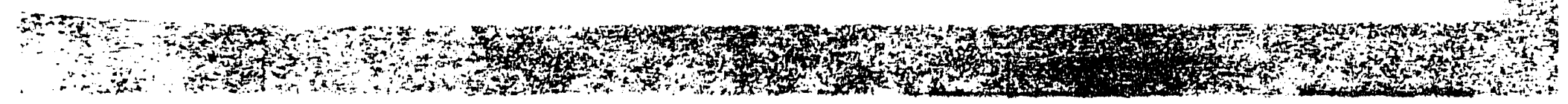




\section{LIST OF TABLES}

Tabile

Page

1 Characteristics of state of the art components for the molen carbonate

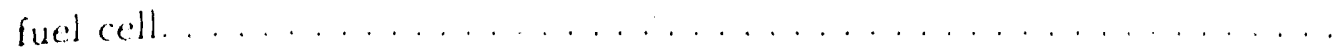

2 Effects of alkali metal content and temperature on the basicity of molten carbonate electrolytes at 1 atm $\mathrm{P}_{\mathrm{CO}_{2}} \ldots \ldots \ldots \ldots \ldots \ldots \ldots \ldots \ldots \ldots \ldots \ldots$ is

3 Comparison of kinetic and mass transfer parameters estimated by complex plane plots and complex nonlinear least square technique; temperature: $750^{\circ} \mathrm{C}$; gas composition: $90 \% \mathrm{O}_{2}$ and $10 \% \mathrm{CO}_{2} \ldots \ldots \ldots 48$

4 Parameters estimated by impedance analysis using CNLS program; gas composition: $90 \% \mathrm{O}_{2}$ and $10 \% \mathrm{CO}_{2}$; parameter $\mathrm{R}_{s}$ : constant parameter.

5 Comparison of product. $\mathrm{D}_{\mathrm{O}}^{1 / 2} \mathrm{C}_{\mathrm{O}}$, estimated by cyciic voltammetry and impedance analysis; gas composition: $90 \% \mathrm{O}_{2}$ and $10 \% \mathrm{CO}_{2} \ldots \ldots \ldots$

(i Influence of $\mathrm{P}_{\mathrm{O}_{2}}$ on product $\mathrm{D}_{\mathrm{O}}^{1 / 2} \mathrm{C} \mathrm{O}$ estimated by cyclic voltammetry and electrochemical impedance spectroscopy at 0.2 atm $\mathrm{P}_{\mathrm{CO}} \ldots \ldots \ldots \ldots$. . . .

- Electrode hinetic and mass transfer related parameters estimated by electrochemical impedance spectroscopy technique at $800^{\circ} \mathrm{C}$ and $0.2 \mathrm{~atm}$

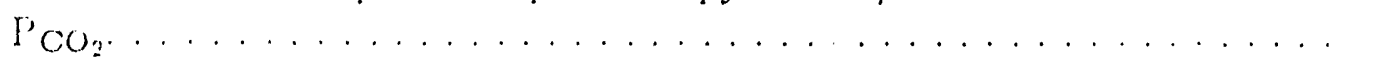

- Electrode tinetic and mass transfer parameters estimated by electrochen. ical impedance suectruscons technique at $850^{\circ} \mathrm{C}$ and 0.2 atm $\mathrm{P}\left(\mathrm{C}_{2} \ldots\right.$. .

4 Comparison of the peroxide concentration determined from $\mathrm{D}_{\mathrm{O}}^{1 / 2} \mathrm{C}_{\mathrm{C}}$ ialue: (for $\left.\mathrm{D}_{\mathrm{O}}=1 \times 11^{-5} \mathrm{c} \mathrm{s}^{-1}\right)$ with hiterature values and themodrnamic data it $800^{\circ} \mathrm{C}$ lemperature and 0.2 atm $\mathrm{PCO}$.

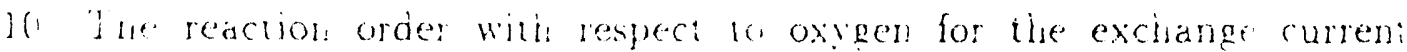

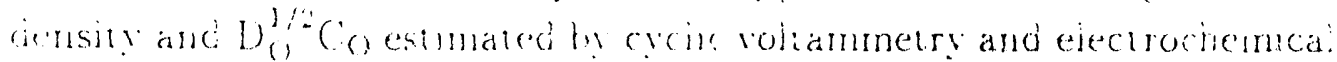

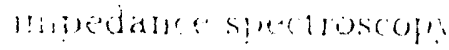

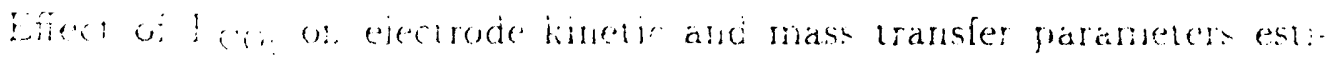

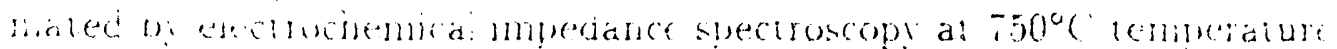

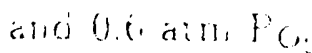


13 Effect of $\mathrm{P} \mathrm{CO}_{2}$ on electrode kinetic and mase iransfer parameters esti. mated by electrochemical impedance spectroscopy at $850^{\circ} \mathrm{C}$ temperature and 0.6 atm $\mathrm{lO}_{2} \ldots \ldots \ldots \ldots \ldots \ldots \ldots \ldots \ldots$

14 Comparison of $\mathrm{D}_{\mathrm{O}}^{1 / 2} \mathrm{C}_{\mathrm{O}}$ values estimated by cyclic voltammetry and electrochemical impedance spectroscopy at 0.6 atm $\mathrm{P}_{\mathrm{O}_{2}} \ldots \ldots \ldots \ldots \ldots$

15 The reaction orders with respect to carbon dioxide for the exchange current density and $\mathrm{D}_{\mathrm{O}}^{1 / 2} \mathrm{C}_{\mathrm{O}}$ determined by cyclic voltammetry and electrochemical impedance spectroscopy. . . . . . . . . . . . . . . . 119

16 Theoretical reaction orders for the exchange current density and the transfer coefficients for oxygen reduction reaction. . . . . . . . . . 15 



\section{L.S1 OH FIGLRIS}

Finu?

l'ate

A schematic of a molten carbunate fuel cell ............... (1

2 Experimental setup for electrode hinetic studies. . . . . . . . . . . . . .

3. Effect of scan rate on cyclic voltammogram for $\mathrm{O}_{2}$ reduction on a sub. merged gold electrode in a pure lithium carbonate meit at $850^{\circ} \mathrm{C} \ldots \ldots . . .33$

4 The Randles-Ershler equivalent circuit. . . . . . . . . . . . . 37

5 The Complex plane impedance plot for a quasi-reversible electrochemical

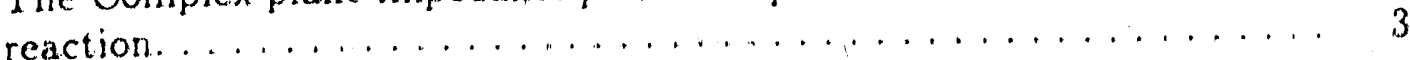

(i Complex plane plow for impedance spectrum measured at the rest potential: the figure insel is a magnified plot for the high frequency data. . . .

- Plor of $Z^{\prime}$ vs. $\omega^{-1 / 2}$ for estimation of Warburg coefficient

- Complex plane impedance plor in a region of low frequency to determine life charge transfer resistance. . . . . ............... 46

$\therefore$ Plot of $Y_{e l}^{\prime \prime} /$ w vs. $Y_{e l}^{\prime \prime} /$ w to determine double layer capacitance. . . . . . . 47

I1) Effect of temperature on a phase angle vs. log w plot for oxiggen reduction on gold electrode in $\mathrm{Li}_{2} \mathrm{CO}_{3}$ melt: working gas $9: 1 \mathrm{O}_{2} / \mathrm{CO}_{2}$.

1: Efiect of temperature on $Z$ is. $n^{-1 / 2}$ for $\mathrm{O}_{2}$ reduction on gold electrode 11. $\mathrm{Lig} 2 \mathrm{CO}_{3}$ melt: working gas $9: 1 \mathrm{O}_{2} / \mathrm{CO}_{2}$ : symbols: expeimental data. clirve lines: modrel predictions.

$\because$ I. fiect of temperature on log $\mid 2$ w. $\log$ w plot for 0 , reduction on gold eicctrode in $\mathrm{Lin}_{2} \mathrm{CO}_{3}$ melt: working gac $9: 10_{2} / \mathrm{CO}_{2}$ symbols: experinenta: ias: curve lines model predicions.

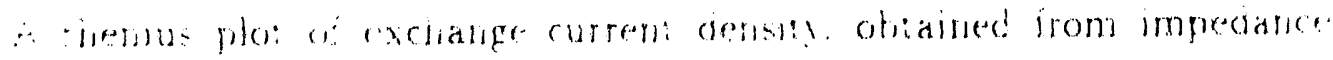

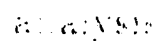

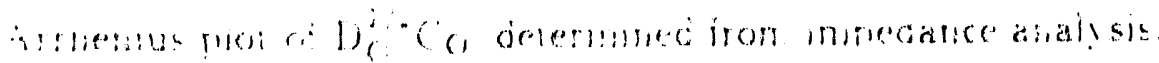

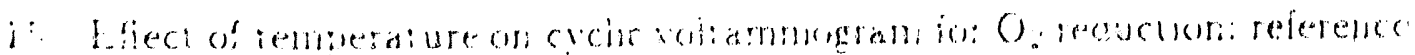

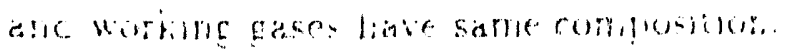




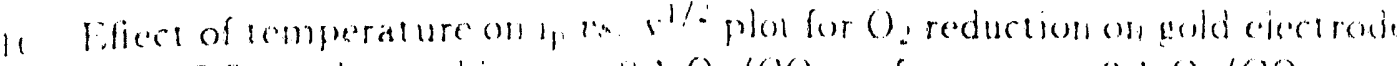

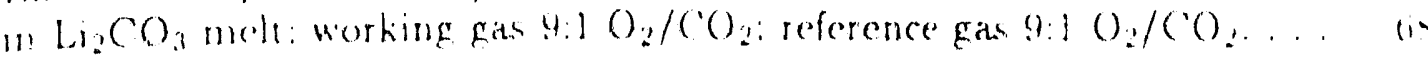

1: Effect of $\mathrm{PO}$, on cyclic voltammogram for (), reduction al $8\left(10^{\circ} \mathrm{C}\right.$ : reference and working gases have same composition. . . . . . . . . . . .

If Effect of $\mathrm{PO}_{2}$ on $\mathrm{i}_{\mathrm{p}}$ us. $\mathbf{1}^{1 / 2}$ plot for $\mathrm{O}_{2}$ reduction on gold electrode in $\mathrm{Li}_{2} \mathrm{CO}_{3}$ melt at 0.2 atm $\mathrm{PCO}_{2}$ and $800^{\circ} \mathrm{C}$; symbols: experimental data:

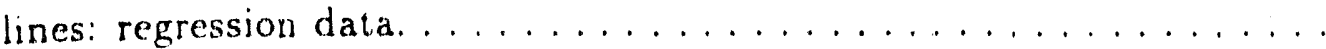

19 Effect of $\mathrm{PO}_{2}$ on cyclic voltammogram for $\mathrm{O}_{2}$ reduction at $850^{\circ} \mathrm{C} ;$ reference and working gases have same composition.

20 Effect of $\mathrm{PO}_{2}$ on $i_{p}$ us. ${ }^{1 / 2}$ plot for $\mathrm{O}_{2}$ reduction on gold electrode in $\mathrm{Li}_{2} \mathrm{C} \mathrm{O}_{3}$ melt at 0.2 atm $\mathrm{PCO}$ and $850^{\circ} \mathrm{C}$; symbols: experimental data: lines: regression data.

23 Plats of $\log \left(\mathrm{D}_{\mathrm{O}}^{1 / 2} \mathrm{C}_{\mathrm{O}}\right)$ vs. $\log \left(\mathrm{P}_{\mathrm{O}_{2}}\right)$ for $\mathrm{O}_{2}$ reaction orders determination at 0.2 atm $\mathrm{P}_{\mathrm{CO}_{2}} ; \mathrm{D}_{\mathrm{O}}^{1 / 2} \mathrm{C}_{\mathrm{O}}$ obtained by cyclic voltammetry. . . . . . . .

2.) Phase angle us. log u' plot as a function of $\mathrm{PO}_{2}$ for $\mathrm{O}_{2}$ reduction on gold electrode in $\mathrm{Li}_{2} \mathrm{CO}_{3}$ melt at 0.2 atm $\mathrm{PCO}_{2}$ and $800^{\circ} \mathrm{C} \ldots \ldots \ldots \ldots$

23 Thase angle us. $\log$ a plot as a function of $\mathrm{PO}_{2}$ for $\mathrm{O}_{2}$ reduction on gold electrode in $\mathrm{Li}_{2} \mathrm{CO}_{3}$ melt at $0.2 \mathrm{~atm} \mathrm{P} C \mathrm{O}$ and $850^{\circ} \mathrm{C}$

$\therefore$ Effect of $\mathrm{PO}$, on $\mathrm{Z}^{\prime}$ 2. . $^{-1 / 2}$ plot for $\mathrm{O}_{2}$ reduction on gold electrode in lin, $\mathrm{CO}_{3}$ meli at 0.2 atm $\mathrm{PCO}_{2}$ and $800^{\circ} \mathrm{C}$ : symbols: experimental data: lines: model dala.

2: Effec of $\mathrm{P}\left(1\right.$, on $\mathrm{Z}$ \% - $^{-1 / 2}$ plot for $\mathrm{O}_{2}$ reduction on gold electrode i.: $0_{3}$ meli a: 0.2 atm PCo. and $850^{\circ} \mathrm{C}$ : symbols: experimental data:

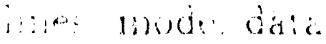
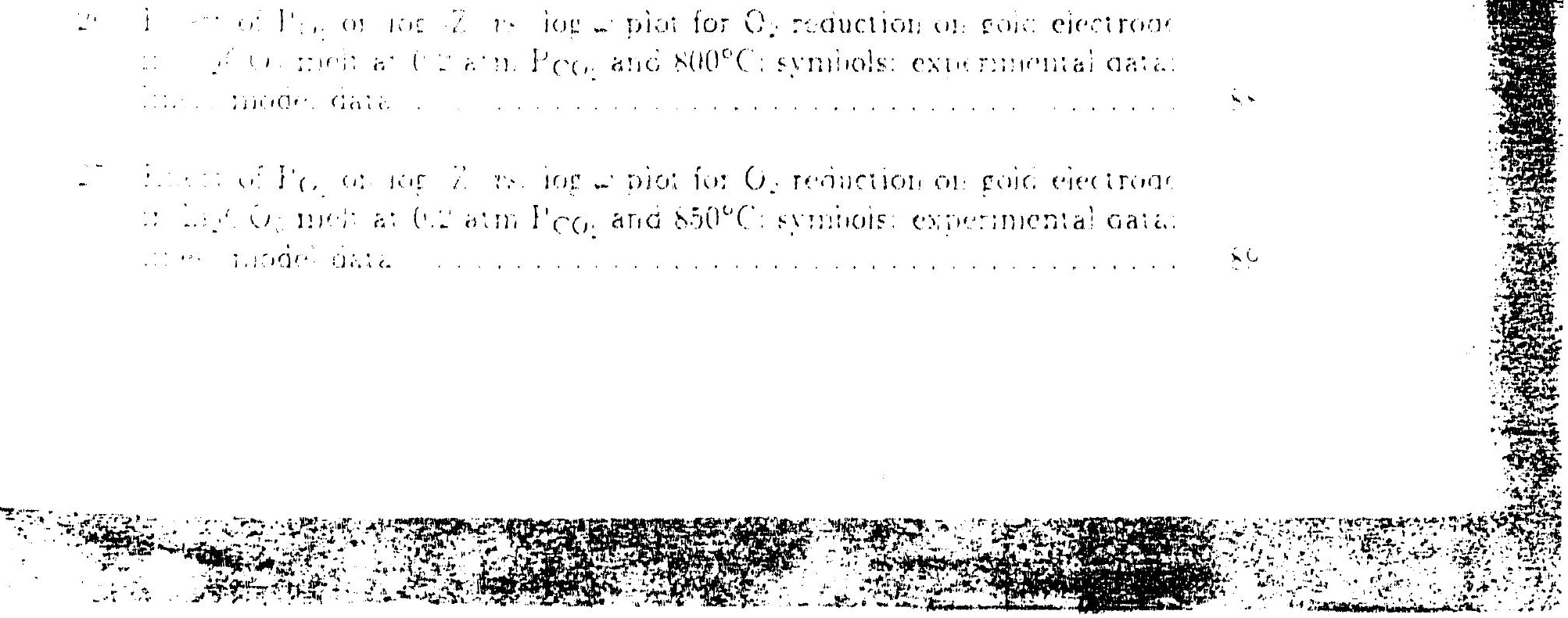
2. Plots of $\log i_{1}$ vs $\log P_{O_{2}}$ for $\mathrm{O}_{2}$ reaction orders determination at $0.2 \mathrm{~atm}$ PCO 2 ; symols: experimental data: lines: regression data . . . . . . .

24 Plots of $\log \left(\mathrm{D}_{\mathrm{O}}^{1 / 2} \mathrm{CO}\right)$ vs. $\log \left(\mathrm{P}^{\mathrm{O}} \mathrm{O}_{2}\right)$ for $\mathrm{O}_{2}$ reaction orders determination at 0.2 atm $\mathrm{PCO}_{2} ; \mathrm{D}_{\mathrm{O}}^{1 / 2} \mathrm{Co}$ estimated by impedance analysis. . . . . . . . .

30 Phase angle us. $\log \omega$ plot as a function of $\mathrm{PCO}_{2}$ for $\mathrm{O}_{2}$ reduction on gold

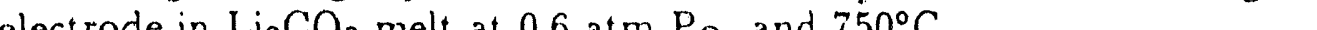

31 Phase angle vs. $\log \omega$ plot as a function of $\mathrm{P}_{\mathrm{CO}_{2}}$ for $\mathrm{O}_{2}$ reduction on gold electrode in $\mathrm{Li}_{2} \mathrm{CO}_{3}$ melt at 0.6 atm $\mathrm{P}_{\mathrm{O}_{2}}$ and $800^{\circ} \mathrm{C} \ldots \ldots \ldots$

32 Phase angle vs. $\log \omega$ plot as a function of $\mathrm{PCO}_{2}$ for $\mathrm{O}_{2}$ reduction on gold electrode in $\mathrm{Li}_{2} \mathrm{CO}_{3}$ melt at 0.6 atm $\mathrm{P}_{\mathrm{O}_{2}}$ and $850^{\circ} \mathrm{C} \ldots \ldots \ldots \ldots$

33 Effect of $\mathrm{P}_{\mathrm{CO}_{2}}$ on $\mathrm{Z}$ ' vs. $\omega^{-1 / 2}$ plot for $\mathrm{O}_{2}$ reduction on gold electrode in $\mathrm{Li}_{2} \mathrm{CO}_{3}$ melt at 0.6 atm $\mathrm{PO}_{2}$ and $750^{\circ} \mathrm{C}$; symbols: experimental data:

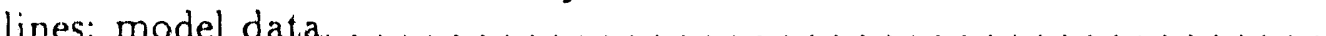

34 Effect of $\mathrm{PCO}_{2}$ on $Z^{\prime}$ vs. $\omega^{-1 / 2}$ plot for $\mathrm{O}_{2}$ reduction on gold electrode in $\mathrm{Li}_{2} \mathrm{C}_{3}$ melt at 0.6 atr $\mathrm{PO}_{2}$ and $800^{\circ} \mathrm{C}$; symbols: experinental data;

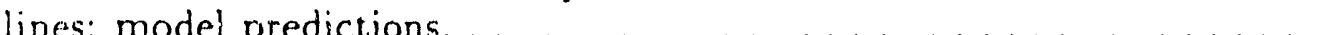

35 Effect of $\mathrm{PCO}_{2}$ on $\mathrm{Z}$ vs. $4^{-1 / 2}$ plot for $\mathrm{O}_{2}$ reduction on gold electrode in $\mathrm{Li}_{2} \mathrm{CO}_{3}$ melt at 0.6 at $\mathrm{PO}_{2}$ and $850^{\circ} \mathrm{C}$; symbols: experimental data: lines: model data.

34. Effect of $\mathrm{PCO}_{2}$ on $\log |\mathrm{Z}|$ vs. $\log \omega$ plot for $\mathrm{O}_{2}$ reduction on gold electrode is $\mathrm{Li}_{2} \mathrm{CO}_{3}$ melt at 0.6 atm $\mathrm{PO}_{2}$ and $750^{\circ} \mathrm{C}$ : symbols: experimental data: innes: model predictions.

3- Effect of $\mathrm{PCO}_{\mathrm{C}}$ on $\log |\mathrm{Z}|$ is. $\log$ i plot for $\mathrm{O}$ ? reduction on gold electrode $11 \mathrm{Lin} \mathrm{CO}_{3}$ nielt at 0.6 atm $\mathrm{PO}$ and $800^{\circ} \mathrm{C}$ : s!mbols: experimental data: i.n. mondel predictions.

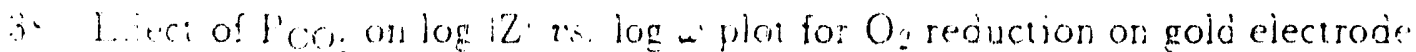

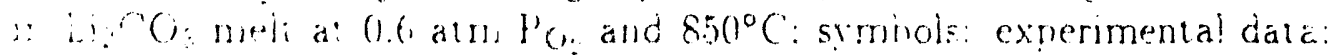

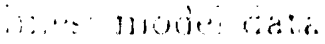

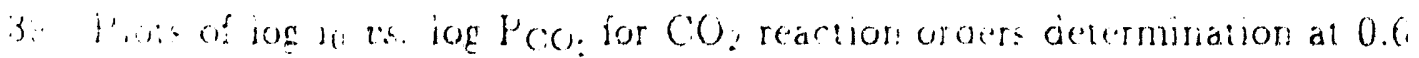

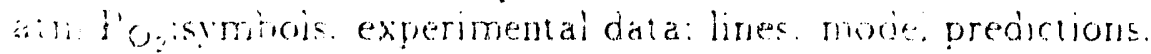


Finure

4 (1) Plots of $\log \mathrm{i}_{0}$ us. $\mathrm{T}^{-1}$ for determination of activation energy' at $6.6 \mathrm{a}: \mathrm{m}$ $\mathrm{P}_{\mathrm{O}_{2}}$ :symbols: experimental data; lines: model predictions. . . . . . . . . 120

41 Plots of $\log \left(\mathrm{D}_{\mathrm{O}}^{1 / 2} \mathrm{CO}\right)$ vs. $\log \left(\mathrm{PO}_{2}\right)$ for $\mathrm{C}_{2}$ reaction orders determination at 0.6 atm $\mathrm{P}_{\mathrm{O}_{2}} ; \mathrm{D}_{\mathrm{O}}^{1 / 2} \mathrm{C}_{\mathrm{O}}$ obtained by impecance analysis. . . . . . . 121

42 Plots of $\log \left(\mathrm{D}_{\mathrm{O}}^{1 / 2} \mathrm{C}_{\mathrm{O}}\right)$ vs. $\mathrm{T}^{-1}$ for activation energy determination at 0.6 atm $\mathrm{P}_{\mathrm{O}_{2}} ; \mathrm{D}_{\mathrm{O}}^{1 / 2} \mathrm{C}_{\mathrm{O}}$ obtained by impedance analysis. . . . . . . . . . 122

43 Effect of $\mathrm{PCO}_{2}$ on cyclic voltammogram for $\mathrm{O}_{2}$ reduction at 0.6 atm $\mathrm{PO}_{2}$ and $750^{\circ}$; reference and working gases have same composition. . . . . . .

44 Effect of $\mathrm{PCO}_{2}$ on cyclic voltammogram for $\mathrm{O}_{2}$ reduction at 0.6 atm $\mathrm{PO}_{2}$ and $800^{\circ}$; reference and working gases have same composition. . . . . . .

45 Effect of $\mathrm{PCO}_{2}$ on cyclic voltammogram for $\mathrm{O}_{2}$ reduction at 0.6 atm $\mathrm{PO}_{2}$ and $850^{\circ}$; reference and working gases have same composition. . . . . . .

$46_{1}$ Effect of $\mathrm{PCO}_{2}$ on $\mathrm{i}_{\mathrm{p}}$ vs. $\mathrm{v}^{1 / 2}$ plot for $\mathrm{O}_{2}$ reduction on gold electrode in $\mathrm{Li}_{2} \mathrm{CO}_{3}$ melt at 0.6 atm $\mathrm{P}_{\mathrm{O}_{2}}$ and $750^{\circ} \mathrm{C} \ldots \ldots \ldots \ldots$

47 Effect of $\mathrm{PCO}_{2}$ on $i_{p}$ vs. $v^{1 / 2}$ plot for $\mathrm{O}_{2}$ reduction on gold electrode in $\mathrm{Li}_{2} \mathrm{CO}_{3}$ melt at 0.6 atm $\mathrm{P}_{\mathrm{O}_{2}}$ and $800^{\circ} \mathrm{C} \ldots \ldots \ldots \ldots$

48 Effect of $\mathrm{PCO}_{2}$ on $i_{p}$ vs. $x^{1 / 2}$ plot for $\mathrm{O}_{2}$ reduction on gold electrode in $\mathrm{Li}_{2} \mathrm{CO}_{3}$ melt at $0.6 \mathrm{~atm} \mathrm{PO}_{2}$ and $850^{\circ} \mathrm{C}$. 


\section{INTRODUCTION}

$A$ fuel cell is an electrochemical device that converts the free energ! of the ractants (fuel and oxidant) directly and continuously into electrical energy. The energy conversion efficiency of a thermal pow $x$ plant is limited by the highest temperature used in the cycle (i.e.. Carnot cycle efficiency). Whereas theoretically; fuel cells can convert all the fret energy available from fuel oxidation reaction into electrical energy: In reality. the energy conversion efficiency of a fuel cell is less than $100 \%$ because of the losses due to irreversibility of the process. Fuel cells have many advantages over the conventional energ!' conversion technologies such as the thermal power plants (11: i) high energ!' conversion efficiency; ii) efficiency relatively independent of load; iiir modular design makes an efficiency of a fuel cell power plant independent of plant scale: iv very low enviunmental impact due to reduced chemical and acoustic [mollution: vi fast reactive power: and vi) multi-fuel abilit?.

Alihough bir Humphrey Davy suggested the fuel celı reactions in $180 \%$ the firs: successful fuel cell was operated by Sir W'illiam Grove (2) in 1839. Grove used Mdrogen and oxygen in his "Ciaseous Voltaic Battery" to produce electricity and waler. Cirove's work was corroborated by Mond and Langer (3, who also found the necessity of preventing the flooding of the platinum black electrode by using a porcus. nonconducting substance to contain the electrolyte. The renascence of fuel cells began in 1950 s when Bacon (4) introduced a fuel cell with dua! porosity electrodes made s: niche! and lithated nickel oxide: modern version of this fuei cell is now used as a

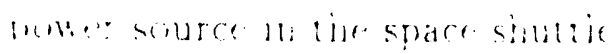

Iype: of luel Cell:

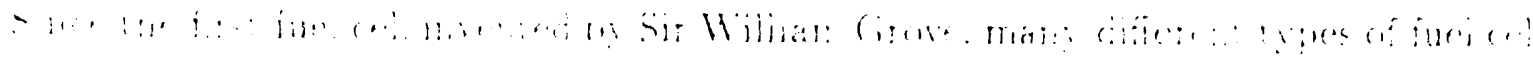

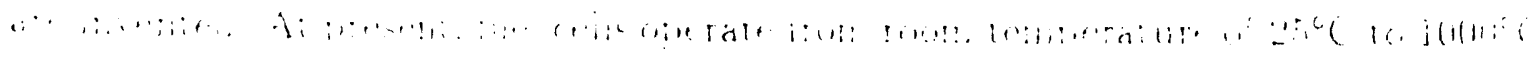


anc: lis variety of fuels such as gaseons hy urogen. alcohols. natural gas. and gasifieci roi. Tine fuel cells classified by the electrolytes are as follows: (i) alkaline fuel cell. (ii) proton exchange membrane fuel cell, (iii) phosphoric acid fuel cell, (iv) molten cartonate fuel cell, and (1) solid oxide fuel cell. The alkaline and proton exchange membrane fuel cells operate at low temperatures and their main application is in spacc. These fuel cells also have very good potential for terrestrial transportation (e.g.. electric vehicles). The other fuel cells operate at higher temperatures and the principal applications are utility power generation, disperse power generation, and industrial cogeneration.

\section{Alkaline Fuel Cell}

The alkaline fuel cell (AFC) operates at about $60^{\circ} \mathrm{C}$ to $80^{\circ} \mathrm{C}$ temperature and contains concentrated $\mathrm{KOH}(\sim 45 \mathrm{wt} \%)$ to lower the vapor pressure of water. The ionic current through the electrolyte is carried by $\mathrm{OH}^{-}$ions. The main advantage of an alkaline clectrolyte is that inexpensive electrocatalysts can be used for oxygen reduction reaction. The porous electrodes made of Raney nickel or PTFE-bonded catalyzed carbon may be used in AFC. The major limitation of the AFC is that high purity of "y.drogen and oxygen is required. Since, the AFC does not reject carbon dioxide. fuel cas derived from the carbonaceous fuel is unsuitable.

\section{Proton Exchange Membrane Fuel cell}

The Proton Exchange Membrane Fuel cell (PEMFC) consists of a solid polymeric ciectrolyte (e.g., perfluorosulfonic acid membrane) sandwiched between two platinum atalyzed. P'TFE bonded carbon clectrodes. The ionic conductivity of the electrolyte :- oue ur the transport of pronos. The PEMFC is a high power densit! fue' ce!:

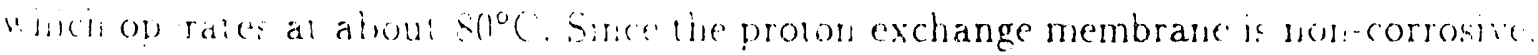

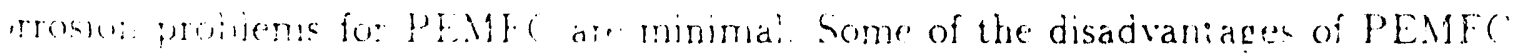

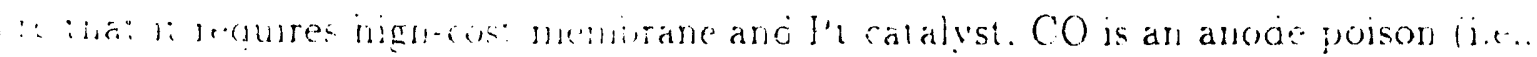

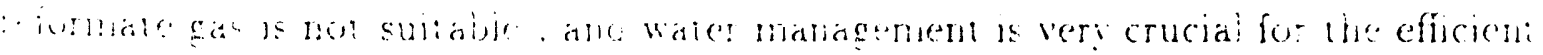

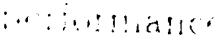


The phosphoric acid fuel cell (PAFC) operates between 100 and $200^{\circ} \mathrm{C}$ temperature. I he porous electrodes consist of carbon supported Pt catalysts bonded with PTFE on a substrate made of carbon. The PAFC is the most advanced fuel cell system for terrestrial power generation. The PAFC has a very high overall fuel efficiency for on-site cogeneration application because the operating temperature is high enough wo produce steam. Also, the phosphoric acid is a $\mathrm{CO}_{2}$-rejecting electrolyte. But oxygen reduction in acid electrolyte is sluggish and requires expensive, noble metals as electrocatalysts. The carbon monoxide is an anode poison; hence hydrogen is the only suitable fuel for direct oxidation.

\section{Molten Carbonate Fue! Cell}

The molten carbonate fuel cell (MCFC) operates at about $650^{\circ} \mathrm{C}$ and the electrolyte consists of an eutectic mixture of lithium and potassium carbonates retained in a porous matrix made of $\gamma-\mathrm{Al}_{2} \mathrm{O}_{3}$. Due to its high temperature, the electrode kinetic rates are high enough that it does not require expensive electrocatalysts; moreover. higi-grade waste heat can be used for internal reforming of $\mathrm{CH}_{4}$. cogeneration. and additional generation of electric power by using a bottoming cycle. The MCFC is expected to have the highest fuel efficiency of all fuel cell systems. Sorne of the probiems associated with MCFC are stability of cell materials. recycling of carbon dioxide. low sulfur tolerance, and high overpntential losses at the oxygen cathode. The detailed description of MCFC is given in the next section

\section{Solid Oxide Fue! Cel!}

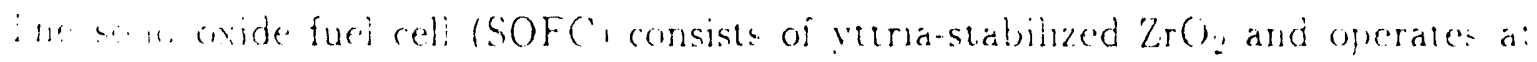

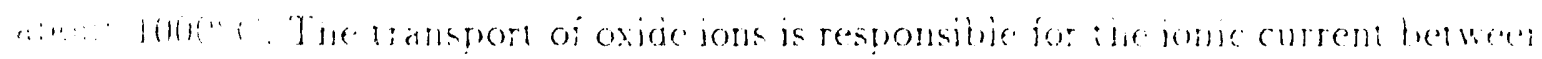

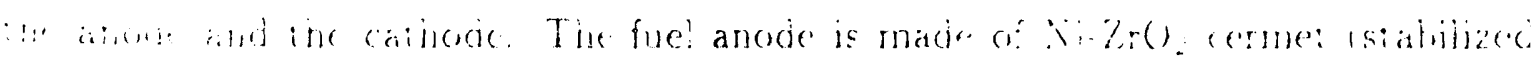

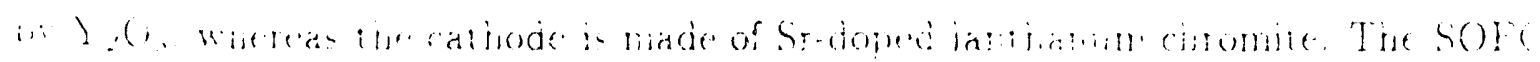

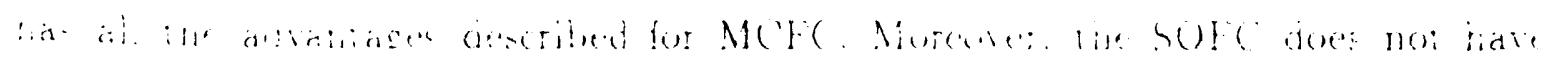


the problem of electrolyte management and does not require recycling of carbon dioxide. Some of the disadvantages of SOFC are high-cost fabrication process and high electrolyte resistivity.

\section{Molten Carbonate Fuel Cell}

Baur et al. (5) developed the first molten carbonate fuel cell, which used an equimolar mixture of sodium and potassium carbonate melt and operated at about $800-900^{\circ} \mathrm{C}$. The major development of MCFC was carried out by Ketelaar and Broers $(6,7)$ in the Netherlands, Gorin and Recht $(\delta, 9)$ in U.S.A., and Chambers and Tantrarn in United Kingdom $(10,11)$. At present Energy Research Corporation (Danbury, CT) and MC Power (Chicago, IL) are leading the molten carbonate fuel cell technolog! in L.S.A.

The molten carbonate fuel cell (MCFC) has many favorable characteristics for utility power generation, because it operates at about $650^{\circ} \mathrm{C}(12.13)$ : i) the polarization losses are reduced to such an extent that it does not require expensive catalysts as it is required in low temperature fuel cells (e.g., phosphoric acid fuel cell); ii) the operating temperature is high enough to produce high quality waste heat, yet it is sufficiently low that the decrease in the free energy is not very large (e.g.. the theoretical open circuit cell voltage is $100 \mathrm{mV}$ higher than that of the solid oxide fuel cell (SOFC) which operates at $1000^{\circ} \mathrm{C}$ ): and iii) the high temperature waste heat can be used for cogeneration, a bottoming cycle and internal reforming of methane. The MCFC operates at about $650^{\circ} \mathrm{C}$ and $160 \mathrm{~mA} \mathrm{~cm}^{-2}$ to produce 0.751 per cell at atmospheric pressure and 50\% fuel (hydrogen) utilization. Inder. pressurized conditions. the performance of MCFC would be even beter.

A schematic of a single MCFC is shown in Fig.1. As the nanue implies. mulie:

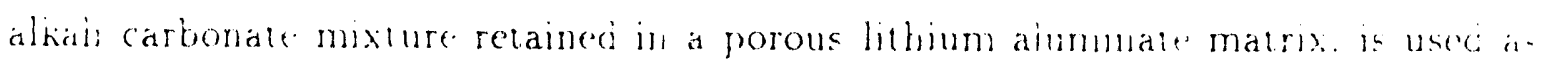

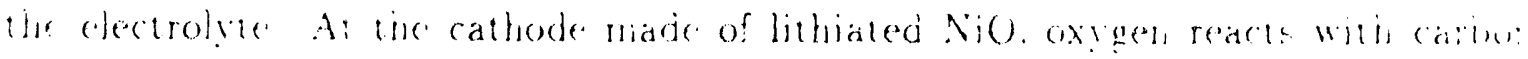

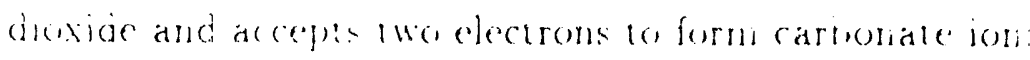

$$
1 / 20)+(0)+20^{-}=(0)
$$


The ionic current through the electrolyte matrix is carried by the carbonate ions from cathode to anode. At the nickel (with $10 \% \mathrm{Cr}$ ) anode, oxidation of hydrogen consumes the carbonate ions and forms water vapor and carbon dioxide:

$$
\mathrm{H}_{2}+\mathrm{CO}_{3}^{2-} \rightleftharpoons \mathrm{H}_{2} \mathrm{O}+\mathrm{CO}_{2}+2 \mathrm{e}^{-}
$$

releasing two electrons to the external crircuit. In a practical MCFC. carbon dioxide produced at the anode need to be transferred to the cathode where it is consumed. The transfer of $\mathrm{CO}_{2}$ from the anode exhaust to the cathode inlet can be carried out in two ways: (i) to burn the spent anode stream with excess air and mix it with the cathode inlet gas after removing the water vapor or (ii) to use a "product exchange device" to separate $\mathrm{CO}_{2}$ from the anode exhaust (1). The latter method provides a richer oxidant since it is not diluted by nitrogen, and hence yields a higher cell vollage.

Characteristics of state of the art components of MCFC are given in Table 1. All three components of the MCFC are now manufactured using the tape casting process. The anode is made of nickel-chromium alloy (2 to $10 \mathrm{wt} \% \mathrm{Cr}$ ). The addition of $\mathrm{Cr}$ prevents the sintering of the porous anode, since it forms $\mathrm{LiCrO}_{2}$ at the grain boundaries and prevents metal diffusion. Recently, it was found that small metal oxide (e.g. $\mathrm{Al}_{2} \mathrm{O}_{3}, \mathrm{LiAlO}_{2}$. etc.) particles, incorporated in the anode, prevent mechanical creep. In addition to its electrocatalytic function. the anode is also required 1.0 function as an electrolyte reservoir. barrier for gas cross-over. and provide structural support the cathode and thin electrolyte matrix in the cell stack. The gas cross-over is prevented by a thin structure of fine porosity which is filled with molten carbonate electrolyte at the anode-electrolyte interface. This layer is called the bubble pressure.

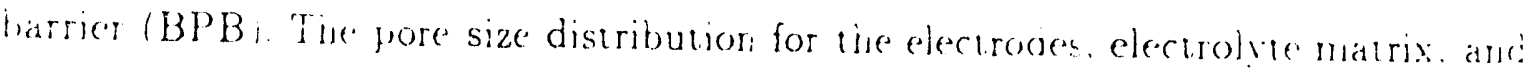

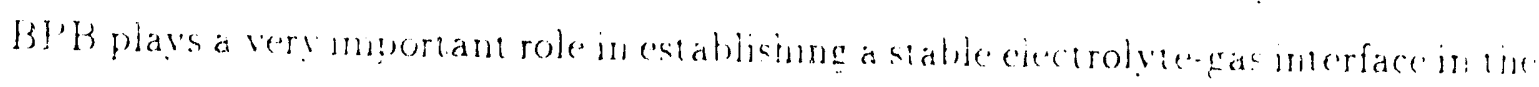

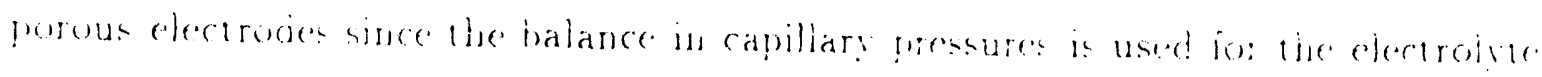

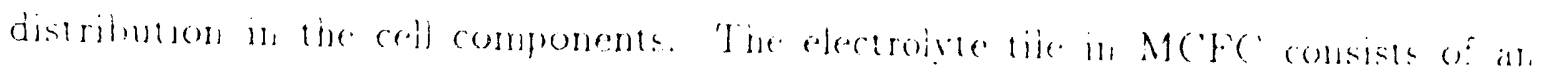

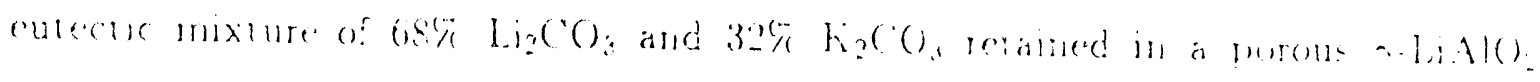

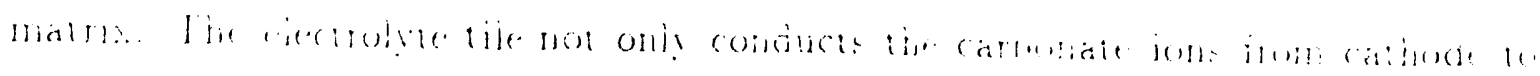




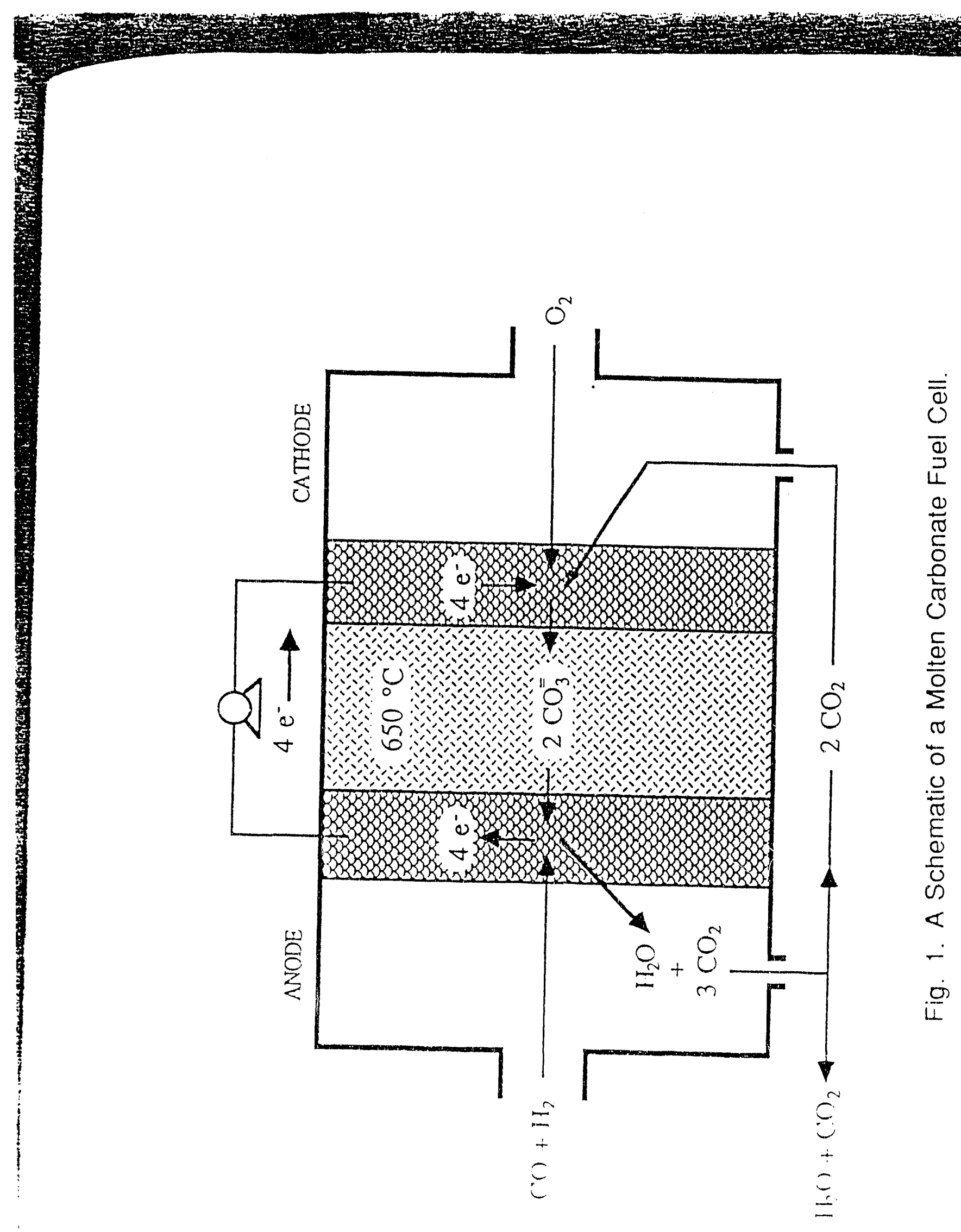


anode but also separates the fuel and oxidant gases. The electrolyte composition is favorable, but by no means is it optimized for MCFC performance and stability. The cations present in molten alkali carbonate electrolyte has a strong effect on the performance and endurance of MCFC. High $\mathrm{Li}^{+}$and $\mathrm{Na}^{+}$contents in the electrolyte increase ionic conductivity while high $\mathrm{K}^{+}$. promotes the gas solubility. The cathode consists of porous lithiated $\mathrm{NiO}$, generally formed by in situ oxjdation and lithiation of sintered nickel. Since lithiated $\mathrm{NiO}$ is a nonstoichiometric compound, $\mathrm{Li}_{x} \mathrm{Ni}_{1-\mathrm{x}} \mathrm{O}$ where $x$ is in the range of $0.022-0.04$, exhibits an electronic conductivity several orders of magnitude higher than that of $\mathrm{NiO}$. As shown in Table 1, the typical thickness of the cathode is lower than that of the anode to lower the total electronic resistance and to obtain a better performance.

The oxygen reduction reaction occurring at the cathode is complex and depends on the cations present in the electrolyte. The oxygen reacts with the carbonate ions to form peroxide and/or superoxide ions. In a pure $\mathrm{Li}_{2} \mathrm{CO}_{3}$ or a $\mathrm{Li}$-rich melt the peroxide species is dominant, whereas in a $\mathrm{K}$-rich melt the superoxide is dominant. In the eutectic mixture of $68 \% \mathrm{Li}_{2} \mathrm{CO}_{3}$ and $32 \% \mathrm{~K}_{2} \mathrm{CO}_{3}$ both peroxide and superoxide species are present (13). The electrolyte distribution is very important for the performance of cathode because it is very sensitive to the degree of filling of the pore volume by electrolyte. The optimum pc filling is about $20 \%$ and even then the overpotentia! losses at the cathode are considerably greater than those occurring at the anode (141. The dissolution of $\mathrm{NOO}$ causes a serious problem by limiting the cell life time. Although the solutility of nichel is far less than that of silver and copper ( $\sim 10 \mathrm{ppm}$. dissolved $\mathrm{NiO}$ may diffuse through the electrolyte towards the anode and metallic $\mathrm{N}$ : may precipitale in the regions of negative potential ii.e. the hydrogen partial pressure is sufficiently high. The deposition of metalie $M$ g grans in the electrolyte matris would eventually cause the electrolyte to become ciectroncally conducting. The rals

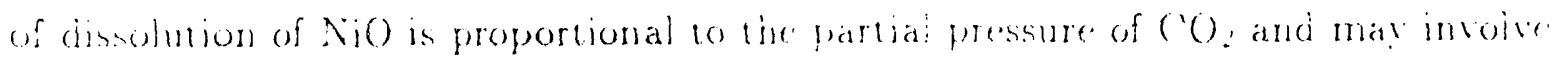
line foliowing reaction

$$
\mathrm{NOO}+\mathrm{CO}=\mathrm{Ni}+1 \mathrm{OH}^{2}
$$


Table 1. Characteristics of State-of-ive-Ant Components for the Molten Carbonate Fuel Cell.

\begin{tabular}{|c|c|}
\hline Component & Current Status \\
\hline Anode & $\begin{array}{l}\cdot \mathrm{Ni}-10 \mathrm{et} \% \mathrm{CT} \\
\cdot 3-6 \mu \mathrm{m} \text { pore size } \\
\cdot 50-70 \% \text { porosity } \\
\cdot 0.5-1.5 \mathrm{~mm} \text { thickness } \\
\cdot 0.1-1 \mathrm{~m}^{2} / \mathrm{g}\end{array}$ \\
\hline Cathode & $\begin{array}{l}\text { - lithiated } \mathrm{NiO} \\
\cdot 7-15 \mu \mathrm{m} \text { pore size } \\
\cdot 70-80 \% \text { porosity } \\
\cdot 0.5-0.75 \mathrm{~mm} \text { thickness } \\
\cdot 0.5 \mathrm{~m}^{2} / \mathrm{g}\end{array}$ \\
\hline Electrolyte Support & $\begin{array}{l}\cdot \gamma-\mathrm{LiAlO} 2 \\
\cdot 0.1-12 \mathrm{~m}^{2} / \mathrm{g}\end{array}$ \\
\hline Electrolyte ${ }^{a}$ & $\begin{array}{l}\cdot 62 \mathrm{Li}-38 \mathrm{~K} \\
\cdot 50 \mathrm{Li}-50 \mathrm{Na} \\
\cdot \text { - } 50 \mathrm{Li}-50 \mathrm{~K} \\
\cdot-50 \mathrm{wt} \%\end{array}$ \\
\hline Fabrication Process & $\begin{array}{l}\text { - tape-cast } \\
-0.5 \mathrm{~mm} \text { thickness }\end{array}$ \\
\hline
\end{tabular}


The dissolution kinetics of $\mathrm{NiO}$ is also a function of basicity of the electrolyte. and hence it depends on the cations present in the melt. Research is in progress to develop alternative cathode materials and to optimize the electrolyte composition (15) to overcome the problem of cathode dissolution.

The bipolar plates in the MCFC stacks are usually fabricated from thin $(\sim 15$ mil) sheets of an alloy (e.g. Type $310 \mathrm{~S}$ or $316 \mathrm{~L}$ stainless steel). The anode side of the bipolar plate is coated with $\mathrm{Ni}$ to prevent corrosion.

The advanced form of molten carbonate fuel cell, known as the internal reforming molten carbonate fuel cell (IRMCFC) or direct fuel cell, may be used to consume the lower hydrocarbons, e.g., CH4, directly. The IRMCFC is intrinsically efficient because water vapor and heat, produced by the exothermic reaction occurring at the anode (Eqn. [2]), provide both the energy and the reactant required for the steam-reforming of methane. Since the standard nickel anode does not bave sufficient activity to reform the required amount of methane to hydrogen, a supported $\mathrm{Ni}$ catalyst is required in IRMCFC. The IRMCFC system operating on natural gas is expected to have an overall efficiency greater than $50 \%$.

The MCFC does not have a problem of $\mathrm{CO}$ poisoning of anode as in low temperature fuel cells such as phosphoric acid and proton exchange membrane fuel cells. in fact $\mathrm{CO}$ in the anode gas stream is used as a fuel. The fuel gas derived from fossil fuel such as coal and natural gas may contain several contaminants such as sulfur-containing compounds, particulates, trace metals etc. The performance of anode is degraded even by the small ( $\sim 1$ ppm) amounts of sulfur present in the fuel or oxidant gas stream. although the degradation is reversible. The adverse effect of $S$ compounds on the performance of MCFC requires prior removal of the sulfur compounds from the fuel gas or periodic purging of sulfur from the system.

I'sed witi: a coal gasifer the MCFC will viold a heat rate better than 6800

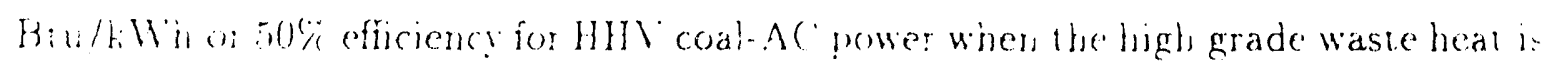

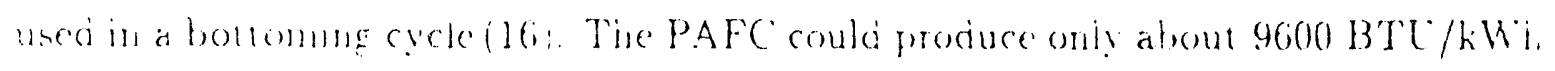

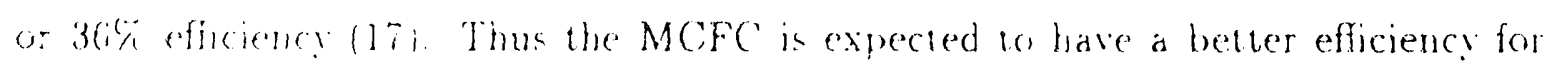


HHV coal-AC power using both coal-derived (18) and natural gas (19) fuels compared to that obtained by the PAFC.

\section{Objectives}

The main purpose of this work is to elucidate oxygen reduction reaction in the molten alkali carbonate electrolyte. The objectives of this research are the following: (i) design and fabrication of an electrochemical cell for high temperature electrode kinetic studies; (ii) study of oxygen reduction in a pure lithium carbonate using electrochem:cal impedance spectroscopic and cyclic voltammetric techniques; (iii) analysis of electrochemical impedance spectra using a Complex Nonlinear Least Square technique to determine electrode kinetic and mass transfer parameters; and (iv) determination of the activation energies and the reaction orders of the electrode kinetic parameters for oxygen reduction in a lithium carbonate melt.

\section{Structure of Dissertation}

This dissertation involves a study of oxygen electrode in the molten carbonate fuel cell. Chapter II describes the oxygen electrode reactions in molten alkali carbonate electrolytes; the reactions include (i) homogeneous chemical reactions equilibria; (ii) concept of acid-base for an electrolyte system containing oxide; and (iii) mechanism for oxygen reduction. In Chapter III, a study of oxygen reaction on a fully-submerged goid electrode in a pure lithium carbonate melt is presented. The experimental se'tup. and electrochemical techniques such as cyclic voltammetry and electrochemical impedance spectroscopy used to study oxygen reduction reaction are also described in Cianler 111. The effects of lemperature partial pressure of oxyen. and partial. presure of carbon dioxide on oxygen reducuon reacton in a pure lithium cartionate

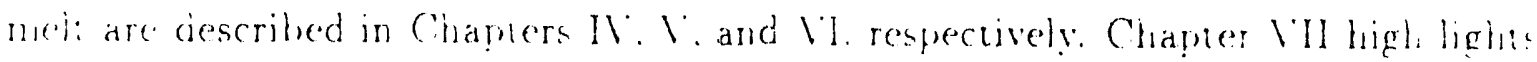

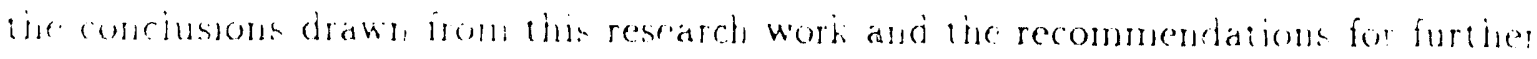

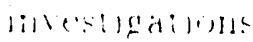




\section{CHAPTER II}

\section{OXYGEN ELECTRODE REACTIONS \\ IN MOLTEN ALKALI CARBONATES}

\section{Introduction}

The oxygen reduction reaction in molten alkali carbonate electrolyte has been studied for the past quarter century because of its vital role in the performance of the molten carbonate fuel cell (MCFC) and the stability of the cell components. The molten electrolyte used in the MCFC may contain a mixture of alkali carbonates such as $\mathrm{Li}_{2} \mathrm{CO}_{3} . \mathrm{Na}_{2} \mathrm{CO}_{3}$, and $\mathrm{K}_{2} \mathrm{CO}_{3}$. Currently, a eutectic mixture of $62 \mathrm{~mol} \% \mathrm{Li}_{2} \mathrm{CO}_{3}$ and $38 \mathrm{~mol} \% \mathrm{~K}_{2} \mathrm{CO}_{3}$ (eutectic temperature $=488^{\circ} \mathrm{C}$ ) is used as an electrolyte, because a high lithium content gives better cell performance. Although an eutectic mixture of $(\mathrm{Li}-\mathrm{K}) \mathrm{CO}_{3}$ is adequate, this composition is not necessarily the optimum. Several factors need to be considered to determine the optimal electrolyte composition (20): (i) ionic conductivity:; (ii) solubility of reactants and products; (iii) diffusion - fficients of reactants and products: (iv) the electrode kinetics of cathodic and nodic reactions: (v) vapor pressure of the electrolyte: and (vi) stability of the cell components e.g. lithium-aluminate matrix and stainless steel current collector. The scivibiln! of cathode made of lithiated- $\mathrm{NiO}$ may be the most important factor in cetemiring the cell life time: the solubility of $\mathrm{NiO}$ in molten alkali is also a iunction: of canom presen m the melt. The ionic conductivity of the electrolyte increases with

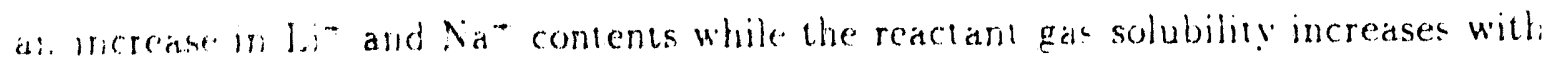

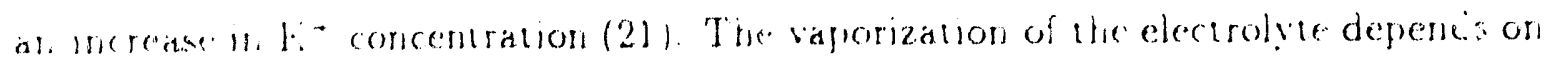

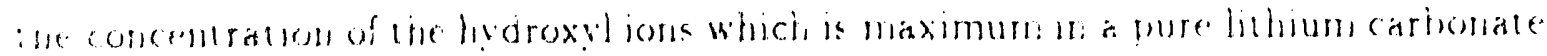
inei: 


\section{Homogeneous Chemical Reactions Equilibria}

The physical solubility of oxygen in molten alkali carbonate electrolytes is insignificant because oxygen reacts with the melt to form electroactive species such as superoxide and/or peroxide ions. Hence, homogeneous chemical reactions play an important role in oxygen reduction reactions in molten alkali carbonates. Andersen (22) suggested following reactions which are vital for the dependence of oxygen reduction mechanism on temperature and alkali metal composition:

$$
\begin{aligned}
\mathrm{O}^{2-}+1 / 2 \mathrm{O}_{2} & =\mathrm{O}_{2}^{2-} \\
\mathrm{O}^{2-}+3 / 2 \mathrm{O}_{2} & =2 \mathrm{O}_{2}^{-} \\
\mathrm{CO}_{3}^{2-} & \rightleftharpoons \mathrm{O}^{2-}+\mathrm{CO}_{2}
\end{aligned}
$$

The combinations of reactions [4] and [5] with [6] result in the formation of peroxide and superoxide ions, respectively:

$$
\begin{aligned}
1 / 2 \mathrm{O}_{2}+\mathrm{CO}_{3}^{2-} & \rightleftharpoons \mathrm{O}_{2}^{2-}+\mathrm{CO}_{2} \\
3 / 4 \mathrm{O}_{2}+1 / 2 \mathrm{CO}_{3}^{2-} & \rightleftharpoons \mathrm{O}_{2}^{-}+1 / 2 \mathrm{CO}_{2}
\end{aligned}
$$

The combination of Eqn. [4] with Eqn. [5] gives the disproportionation reaction between peroxide and superoxide species (23):

$$
\mathrm{O}_{2}^{2-}+2 \mathrm{O}_{2}^{-}=2 \mathrm{O}^{2-}+2 \mathrm{O}_{2}
$$

\section{Acid-Base Relationship in Molten Alkali Carbonates}

In $1923 \mathrm{~J}$. N. Bronsted and T. M. Lowry proposed independently a concept of acidbase relationship that applies to aqueous as well as nonaqueous systems (24). The Bronsted-Lowry theory states that an acid is a proton donor and a base is a proton acceptor. This theory is summarized by the following equation:

$$
\text { Acid }=\text { Conjugate Base }-\mathrm{H}^{-}
$$

The acid and base in this relation are known as a conjugate parr. The Bronsted-Lowry theory is actually a special case of a more general acid-base theory propused by (i. 
N. Lewis which is applicable to solvents other than proton-donating ones. The Lewis theory states that an acid is a acceptor of a pair of electrons whereas a base is a donor of a pair of electrons to form a covalent bond.

Lux (25) extended the acid-base concept to molten salts containing oxide ions. Flood and Forland (26) further developed the concept, which states that an acid is an oxide ion acceptor and a base is an oxide ion donor. Similar to the Brønsted-Lowry theory, the Lewis-Flood theory for the oxide systems can be expressed as

$$
\begin{aligned}
\text { Acid }+\mathrm{O}^{2-} & =\text { Conjugate Base } \\
\text { Base } & \rightleftharpoons \text { Conjugate Acid }+\mathrm{O}^{2-}
\end{aligned}
$$

Based on the Lux-Flood theory and Eqns. [4]-[6], oxygen and carbon dioxide are considered to be acids while peroxide, superoxide and carbonate ions are bases. The acid-base relationship defined by Lux-Flood theory is ambiguous. For example. superoxide is an acid with respect to peroxide, since superoxide ion accepts oxide ion to form peroxide:

$$
\mathrm{O}_{2}^{-}+\mathrm{O}^{2-}=3 / 2 \mathrm{O}_{2}^{2-}
$$

But. according to Eqn. [5] the superoxide ion is defined as a base since it donates an oxide ion to release oxygen.

The basicity of the molten alkali carbonate electrolyte depe ds on the activity of the oxide ions and partial pressure of oxygen. Lu (23) suggested a function $\mathrm{pO}^{2-}$ as a measure of the basicity of the molten carbonate containing oxide species. The function $\mathrm{pO}^{2--}$ is similar to the concept of $\mathrm{pH}$ in the protogenic solvents:

$$
\mathrm{pO}^{2-}=-\log \mathrm{aO}:-
$$

The artivity o; oxide ions in molten alkali carbonates electrolyte depends on th dissociation process. The dissociation equilibrium is given as:

$$
\mathrm{M}_{2} \mathrm{CO}_{3(1)}=\mathrm{M}_{2} \mathrm{O}_{(1)}+\mathrm{CO}_{2(\mathrm{I})}
$$

$0:$

$$
\mathrm{CO}_{3}^{:-}=0^{2-}+\mathrm{CO}
$$


where. $M$ is an alkali metal such as Li. $\mathrm{Na}$. or $\mathrm{K}$. The thermodynamic dissociation constant is defined as:

$$
\mathrm{K}_{\mathrm{d}}=\frac{\mathrm{a}_{\mathrm{O}^{2-}} \cdot \mathrm{PCO}_{2}}{\mathrm{a}_{\mathrm{CO}_{3}{ }^{2-}}}
$$

Using Eqn. [17], the function $\mathrm{pO}^{2-}$ may be determined as a function of the dissociation equilibrium constant and partial pressure of carbon dioxide making the assumption that activity of the carbonate ions is invariant and equal to unity:

$$
\mathrm{pO}^{2-}=-\log \left(\frac{\mathrm{h}_{\mathrm{d}}}{\mathrm{PCO}_{2}}\right)
$$

The values of $\mathrm{pO}^{2-}$ were calculated as a function of temperature and alkali metal content for 1 atm partial pressure of carbon dioxide using the thermodynamic data obtained by Andersen (22); the values are given in Table 2. As shown in Table 2. the dissociation constant decreases in several order of magnitude in the order $\mathrm{Li}^{+}>\mathrm{Na}^{+}>\mathrm{K}^{+}$, i.e., for the same temperature and partial pressure of carbon dioxide. a pure lithium carbonate melt has the highest concentration of the oxide ions. While a pure potassium carbonate melt has the lowest oxide content among these melts. The dissociation constant $k_{d}$ also decreases with an increase in temperature. Hence, the basicity of molten carbonate electrolyte is a function of alkali metal content. Lemperature. and partial pressure of carbon dioxide. The basicity of the melt increases with an increase in lithium-ion content anci cemperature and a decrease in: partial pressure of carbon dioxide.

Oxygen Reduction in Molten Alkali Carbonate Electrolyes

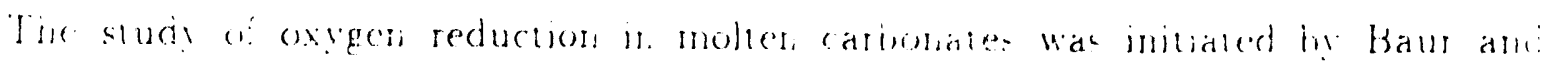

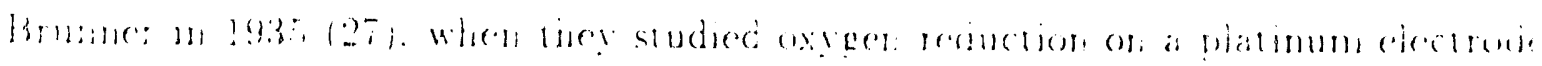

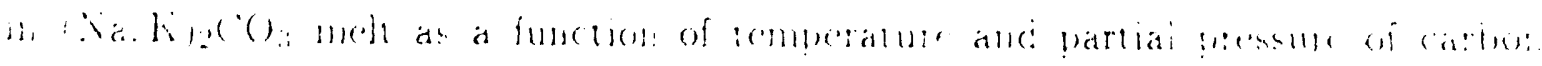

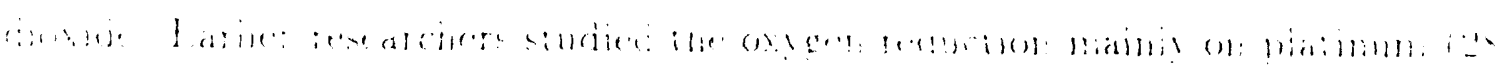

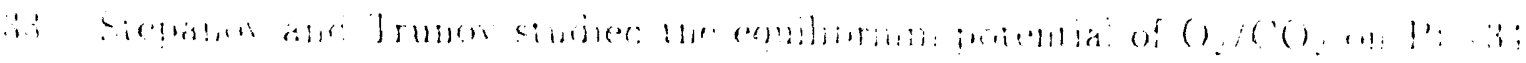


Table 2. Effects of Alkali Metal Content and Temperature on the Basicity of Molten Carbonate Electrolytes at 1 atm $\mathrm{PCO}_{2}$.

\begin{tabular}{|c|c|c|c|}
\hline \multirow{2}{*}{$\begin{array}{c}\text { Temperature } \\
{ }^{\circ} \mathrm{C}\end{array}$} & \multicolumn{3}{|c|}{$\mathrm{pO}^{2-}$} \\
\cline { 2 - 4 } & $\mathrm{Li}_{2} \mathrm{CO}_{3}$ & $\mathrm{Na}_{2} \mathrm{CO}_{3}$ & $\mathrm{~K}_{2} \mathrm{CO}_{3}$ \\
\hline 900 & 2.23 & 6.14 & 7.78 \\
950 & 1.89 & 5.59 & 7.16 \\
1000 & 1.58 & 5.09 & 6.58 \\
\hline
\end{tabular}


and the mechanism of oxygen reduction reaction on $\mathrm{Pt}_{t}$ and on porous $\mathrm{Ag}(35)$ and concluded that the overall reaction is

$$
1 / 2 \mathrm{O}_{2}+\mathrm{CO}_{2}+2 \mathrm{e}^{-} \rightleftharpoons \mathrm{CO}_{3}^{2-}
$$

Platinum is unstable in molten carbonate electrolytes $(28,36,37)$ and forms complex oxide (37). Janz and Saegusa (30) showed that gold is more stable than platinum in the molten carbonate environment. The oxygen reduction on a gold electrode was also investigated by Busson et al. $(38-40)$ and Borucka $(41,42)$. Borucka and Sugiyama $(43,44)$ conducted the kinetic studies of oxygen reduction on a $\mathrm{O}_{2} / \mathrm{CO}_{2} / \mathrm{Au}$ electrode in a ternary $\left(43.5 \mathrm{~mol} \% \mathrm{Li}: 31.5 \mathrm{~mol} \% \mathrm{Na}: 25.0 \mathrm{~mol}^{\circ} \mathrm{K}\right) \mathrm{CO}_{3}$ eutectic melt in the temperature range of $550-800^{\circ} \mathrm{C}$ and concluded the following: (i) the effects of the partial pressures of oxygen and carbon dioxide on the equilibrium potential show that the overall reaction at the equilibrium is represented by Eqn. [19] and the equilibrium potential obeys the corresponding Nernst equation

$$
\mathrm{E}_{\mathrm{O}_{2}, \mathrm{CO}_{2} / \mathrm{CO}_{3}^{2-}}=\mathrm{E}_{\mathrm{O}_{2}, \mathrm{CO}_{2} / \mathrm{CO}_{3}^{2-}}+\frac{\mathrm{RT}}{2 \mathrm{~F}} \ln \left(\mathrm{P}_{\mathrm{O}_{2}}^{1 / 2} \mathrm{P}_{\mathrm{CO}_{2}}\right)
$$

(ii) the micropolarization tests at near-equilibrium indicate that the electrode is under "mixed" control (due to the charge transfer and mass transport processes). even close to the equilibrium; and (iii) the exchange density for the electrode reaction (Eqn. [19]) is about $0.1 \mathrm{~mA} \mathrm{~cm}^{-2}$. Appleby and Nicholson (45 - 49) examined the oxygen reduction reaction in molten carbonates on a submerged gold electrode using steady-state and potential-scan techniques. Appleby and Nicholson concluded that oxygen reacts with carbonate ions to form peroxide and/or superoxide ions and the concentrations of these species depend on the cations present in the melt. In a pure $\mathrm{Li}_{2} \mathrm{CO}_{3}$ or a Li-rich melt. the peroxide species is dominant. whereas in a $\mathrm{K}$-rich meli the superoxide species is dominant. The existence of peroxide and/or superoxiot speries is aiso reported in the oxide-containing molien systems of fiuorider fiti: nitrites (51), and chlorides (52). Appleby and Nicholson also examined the oxines: reduction reaction in binary $(43$ mol $\% \mathrm{Na}: 57 \mathrm{~mol} \% \mathrm{~K}$ ) and ternary $(43.5$ moll $\%$ l.; 31.5 mol\% $\mathrm{Na}: 25 \mathrm{~mol}(\% \mathrm{~K})$ eutectics in the temperature range of $700\left(1010^{\circ} \mathrm{C}^{\circ}\right.$ anc: 
concluded that (47): (i) the electroactive species is not the diatomic oxygen molecule: (ii) both peroxide and superoxide ions are present; and (iii) the neutralization of the oxide ions by carbon dioxide (Eqn. [24]) is slow, and may be controlled by diffusion. Appleby and Nicholson (48) investigated the electrode kinetics of oxygen reduction on a fully-submerged gold electrode in the binary $\left(47 \mathrm{~mol} \% \mathrm{Li}: 53 \mathrm{~mol} \% \mathrm{~K}\right.$ ) $\mathrm{CO}_{3}$ eutectic melt over the temperature range of $700-800^{\circ} \mathrm{C}$ and concluded that both peroxide and superoxide species are present in the melt, and are reduced in parallel steps. The reduction peaks for these species are closer in this melt compare to those in the binary ( $43 \mathrm{~mol} \% \mathrm{Na}: 57 \mathrm{~mol} \% \mathrm{~K}$ ) melt. The exchange current density values (e.g., $0.37 \mathrm{~mA} \mathrm{~cm}^{-2}$ at $700^{\circ} \mathrm{C}$ and gas composition of $90 \% \mathrm{O}_{2}$ and $10 \% \mathrm{O}_{2}$ ) in the $\mathrm{Li} / \mathrm{K}$ melt are higher than those in the $\mathrm{Na} / \mathrm{K}$ melt (e.g., $0.18 \mathrm{~mA} \mathrm{~cm}^{-2}$ at $700^{\circ} \mathrm{C}$ and gas composition of $90 \% \mathrm{O}_{2}$ and $\left.10 \%, \mathrm{O}_{2}\right)$. Dunks and Stelman (53) studied the oxygen reduction in a pure sodium carbonate melt at $900^{\circ} \mathrm{C}$ using cyclic voltammetric and computer-curve fitting and proposed the presence of percarbonate ions. They also confirmed the existence of the superoxide ions in the frozen electrolyte from the Electron Spin Resonance (ESR) spectrum obtained at $77 \mathrm{~K}$ temperature. Andersen (22) carried out a thermodynamic study of the chemical equilibria in molten alkali carbonate electrolytes and determined the amount of oxide, peroxide and superoxide jons by quenching the melt followed by chemical analyses. The physical evidence of the percarbonate ions in molten carbonate is not available. The oxygen reduction mechanisms based on peroxide. superoxide. and percarb rate paths are described ineicin:

l'orosiceratin

$$
\begin{aligned}
& 1 / 2 \mathrm{O}_{2}+\mathrm{CO}_{3}^{2-}=\mathrm{O}_{2}^{2-}+\mathrm{CO} \\
& \mathrm{O}^{2-}+\mathrm{O}^{-}=\left(\mathrm{O}^{-}\right)+\mathrm{O}^{2-} \\
& \mathrm{CO}^{-}+\mathrm{CO}_{2}+\mathrm{e}^{-}=\mathrm{CO}_{3}^{2-} \\
& \mathrm{O}^{2-}+\mathrm{CO}_{2}=\mathrm{CO}_{3}^{:-}
\end{aligned}
$$

Goral! hed ion 


$$
1 / 2 \mathrm{O}_{2}+\mathrm{CO}_{2}+2 \mathrm{e}^{-}=\mathrm{CO}_{3}^{2-}
$$

where $\left(\mathrm{O}^{-}\right)$is a transient species and the first charge transfer reaction (Eqn. (22]) is the rate determining step for an immersed electrode.

Superoxide Path

$$
\begin{aligned}
3 / 4 \mathrm{O}_{2}+1 / 2 \mathrm{CO}_{3}^{2-} & \rightleftharpoons \mathrm{O}_{2}^{-}+1 / 2 \mathrm{CO}_{2} \\
\mathrm{O}_{2}^{-}+\mathrm{e}^{-} & \rightleftharpoons \mathrm{O}_{2}^{2-} \\
\mathrm{O}_{2}^{2-}+\mathrm{e}^{-} & \rightleftharpoons\left(\mathrm{O}^{-}\right)+\mathrm{O}^{2-} \\
\left(\mathrm{O}^{-}\right)+\mathrm{CO}_{2}+\mathrm{e}^{-} & \rightleftharpoons \mathrm{CO}_{3}^{2-} \\
\mathrm{O}^{2-}+\mathrm{CO}_{2} & \rightleftharpoons \mathrm{CO}_{3}^{2-}
\end{aligned}
$$

Overall Reaction

$$
3 / 4 \mathrm{O}_{2}+3 / 2 \mathrm{CO}_{2}+3 \mathrm{e}^{-}=3 / 2 \mathrm{CO}_{3}^{2-}
$$

\section{Percarbonate Path}

$$
\begin{aligned}
1 / 2 \mathrm{O}_{2}+\mathrm{CO}_{3}^{2-} & =\mathrm{CO}_{4}^{2-} \\
\mathrm{CO}_{4}^{2-}+\mathrm{e}^{-} & =\mathrm{CO}_{3}^{2-}+\left(\mathrm{O}^{-}\right) \\
\left(\mathrm{O}^{-}\right)+\mathrm{e}^{-} & =\mathrm{O}^{2-} \\
\mathrm{O}^{2-}+\mathrm{CO}_{2} & =\mathrm{CO}_{3}^{2-}
\end{aligned}
$$

Overall Reaction

$$
1 / 2 \mathrm{O}_{2}+\mathrm{CO}_{2}+2 e^{-}=\mathrm{CO}_{3}^{2-}
$$

The equations illustrating the dependence of the exchange current density on $\mathrm{PO}_{\text {: }}$ and $\mathrm{PCO}_{2}$ are derived in Appendix $A$. The exchange current density is related to $\mathrm{PO}_{\mathrm{O}}$ and $\mathrm{PCO}_{\mathrm{CO}}$, by the following expression:

$$
i_{0}=i_{0}^{\prime \prime}\left(\mathrm{P}^{3}\right)^{i}\left(\mathrm{PCO}_{2}\right)^{t}
$$

where. $i_{11}^{0}$ is the kinetic parameter at a reference state, as indicaled by super 0 . and is function of temperature only; a is the reaction order with respect to oxygen. and $b$ 
is the reaction order with respect to carbon dioxide. The theoretical reaction orders for the exchange current density and the transfer coefficients determined for various reaction mechanisms are shown in Appendix A.

Tang et al. (54) examined the effect of gas composition on oxygen reduction kinetics on a porous $\mathrm{NiO}$ at $650^{\circ}$. The apparent exchange current density was obtained from low polarization $(<10 \mathrm{mV}$ ) data with the assumption that the electrode reaction is under kinetic control. The kinetic reaction orders determined by Tang et al. are inconsistent with the theoretical mechanisms. Winnick and Ross (55) investigated the oxygen reduction kinetics on porous $\mathrm{NiO}$ in $(\mathrm{Li}, \mathrm{K})_{2} \mathrm{CO}_{3}$ eutectic melt using steadystate polarization technique. These researchers concluded that the kinetic reaction orders for oxygen and carbon dioxide are 0.25 and 0.625 , respectively. These reaction orders do not concur with the any of the mechanism proposed in the literature. The discrepancy in the reaction orders determined by Tang et al. and Winnick and Ross may have been due to the effect of mass transfer polarization.

Appleby and Van Drunen (56) determined the total solubility of oxygen (mainly in the form of peroxide and superoxide ions) in the molten alkali carbonates as a function of temperature using the quenching method. Vogel et al. (57) investigated the $(\mathrm{Li}-\mathrm{K}) \mathrm{CO}_{3}$ eutectic melt at $650^{\circ} \mathrm{C}$, using a rotating gold wire and concluded that superoxide is dominant in this melt and presence of molecular oxygen in the melt is negligible. Smith et al. (58) determined the total solubility of oxygen in ( $\mathrm{Li}-\mathrm{Na}$ $\mathrm{K}$ ) $\mathrm{CO}_{3}$ ternary eutectic melt as a function of gas composition at $650^{\circ} \mathrm{C}$ by a chemical method. They concluded that oxygen reacts with $(\mathrm{Li}-\mathrm{Na}-\mathrm{K}) \mathrm{CO}_{3}$ melt at $650^{\circ} \mathrm{C}$ to form superoxide ions and the concentration of the physically dissolved. molecular oxygen is negligible. White and Twardoch (59) examined the ( $\mathrm{Li}-\mathrm{Na}-\mathrm{K}$ ) $\mathrm{CO}_{3}$ eutectic melt at $680^{\circ} \mathrm{C}$ by cyclic voltammetry, chronopotentiometry, and chronoamperometry. and indicated the simultaneous presence of peroxide and oxide jons.

Yuh (60) used electrochemical impedance spectroscopy and current interruption techniques to characterize the oxygen reduction process on porous $\mathrm{NiO}$ in the molten carbonate fuel cell. Y'uh determined the activation energy of oxygen reduction to be about $230 \mathrm{hJ} / \mathrm{mol}$ and kinetic reaction orders for oxygen and carbon dioxide co be 
0.85 and -0.45 , respectively. Lu (23) investigated the oxygen reduction reaction in pure $\mathrm{Li}_{2} \mathrm{CO}_{3}$ and a $\mathrm{Li}-\mathrm{K}(62 \mathrm{~mol} \%: 38 \mathrm{~mol} \%)$ carbonate eutectic mixture using the potential step method. The exchange current density, determined by $\mathrm{Lu}\left(39 \mathrm{~mA} / \mathrm{cm}^{2}\right.$ for $90 \% \mathrm{O}_{2}$ and $10 \% \mathrm{CO}_{2}$ at $750^{\circ} \mathrm{C}$ in $\mathrm{Li}_{2} \mathrm{CO}_{3}$ melt), is two orders of magnitude higher than that observed by Appleby and Nicholson $\left(0.34 \mathrm{~mA} / \mathrm{cm}^{2}\right)$, who used the potential-scan technique. The dependence of oxygen reduction kinetics on partial pressures of oxygen and carbon dioxide observed, by $\mathrm{Lu}$, is as follows:

$\underline{\mathrm{Li}_{2} \mathrm{CO}_{3} \text { Melt : }}$

$$
i_{0}=i_{0}^{0}\left(P_{\mathrm{O}_{2}}\right)^{0.15 \pm 0.04}\left(\mathrm{P}_{\mathrm{CO}_{2}}\right)^{-0.10 \pm 0.03}
$$

$\underline{(\mathrm{Li}, \mathrm{K})_{2} \mathrm{CO}_{3} \text { Melt : }}$

$$
i_{0}=i_{0}^{0}\left(P_{\mathrm{O}_{2}}\right)^{0.12 \pm 0.03}\left(\mathrm{P}_{\mathrm{CO}_{2}}\right)^{-0.12 \pm 0.03}
$$

The reaction observed by Lu cannot be explained by any of the mechanism proposed in the literature. Uchida et al. (61) determined the kinetic parameters for oxygen reduction in a $(\mathrm{Li}-\mathrm{K}) \mathrm{CO}_{3}(42.7 \mathrm{~mol} \%: 57.3 \mathrm{~mol} \%)$ eutectic melt on a gold electrode using impedance analysis, potential step and coulostatic relaxation methods. They found that thr exchange current density was about the same order of magnitude as that observed by Lu. In addition, they concluded that impedance analysis is the most reliable of the three methods for the determination of the kinetic parameters for oxygen reduction in molten carbonates. Uchida et al. (62) examined the oxygen reduction on a lithiated $\mathrm{NiO}$ film, deposited on gold, and $\mathrm{Sb}$-doped $\mathrm{SnO}_{2}$ electrodes in Li-K eutectic melt by impedance spectroscopy and coulostatic relaxation techniques. They (63) also determined the temperature dependence of oxygen reduction kinetics on gold in $(\mathrm{Li}-\mathrm{K}) \mathrm{CO}_{3}$ and determined the activation energies for the kinetic and mass transfer related parameters. Also. Adanuvor et al. (64) showed that a computer simulation is a better approach than the conventional approaches since it can take account of the simultaneous presence of peroxide and superoxide ions with slow neutralization reaction. The simulation results indicate that the melss with high

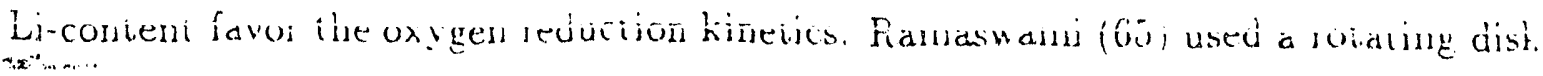


electrode, made of pure gold, to study the oxygen reduction reaction in a pure lithium carbonate melt at $800^{\circ} \mathrm{C}$, and determined the diffusion coefficient and peroxide ion concentration as a function of partial pressure of oxygen while keeping the partial pressure of carbon dioxide constant at $0.01 \mathrm{~atm}$.

Nishina and Uchida (66) investigated the oxygen reduction mechanism in molten carbonate electrolytes by electrochemical impedance spectroscopy. They used Randles-Ershler equivalent circuit for a planar gold electrode and the thin film model with the Nernst impedance for a sintered gold electrode to determine Warburg impedance and concluded that the simultaneous diffusion of superoxide ions and carbon dioxide is the dominant path for the oxygen reduction in molten alkali carbonate electroly ‘es. Makkus et al. (67) included the Gericher impedance (i.e., impedance due to the homogeneous chemical reaction) to resolve the impedance spectra for oxygen reduction in ( $\mathrm{Li}-\mathrm{K}) \mathrm{CO}_{3}$ eutectic melt, but estimated reaction orders for oxygen and carbon dioxide do not agree with the reaction mechanisms proposed in the literature. Makkus et al. suggested that diffusing species could be percarbonate ions. Recently, Tryk and Yeager (68) have shown the existence of peroxide and superoxide species in quenched molten alkali carbonates by electron spin resonance spectroscopy and Raman spectroscopy, but the existence of percarbonate ions in the molten carbonate electrolytes has not been published.

\section{Conclusions}

The mechanism of oxygen reduction in molten carbonate is not well understood anc the results reported in the literature are not consistent. Moreover, oxygen reduction in molten carbonate has fast kinetics, and even near-equilibrium tests reported in the literature indicate mixed-control kinetics. The previous studies show that the presence of physically dissolved molecular oxygen in molten carbonate electrolyte is insignificant. Oxygen reacts with the molten alkali carbonates to form peroxide and/or superoxide ions: the concentrations of ther species depend on the catoms present in the melt. Thermodinamic data (22) indicate that equilibrium: concentration of the superoxide ion decreases with decrease in the ionic radij of the 
alkali cations (i.e., $\mathrm{C}_{\mathrm{O}_{2}^{-}}$decreases in the order $\mathrm{K}_{2} \mathrm{CO}_{3}>\mathrm{Na}_{2} \mathrm{CO}_{3}>\mathrm{Li}_{2} \mathrm{CO}_{3}$ ), and in a pure lithium carbonate melt the superoxide ion is unstable. Consequently, in the present work, pure lithium carbonate melt is used to avoid the complexity of simultaneous formation of peroxide and superoxide ions. 


\section{CHAPTER III}

\section{OXYGEN REDUCTION IN LITHIUM CARBONATE MELT}

\section{Introduction}

Study of oxygen reduction in a molten alkali carbonate electrolyte is essential because the overpotential losses in molten carbonate fuel cells are considerably higher at the oxygen cathode compared to those occurring at the fuel anode. The oxygen reduction reaction in molten alkali carbonate electrolyte is very complex because it depends on the cations present in the melt. The previous research efforts $(22,46,57)$ have shown that the physical solubility of molecular oxygen in the molten carbonates is very small and oxygen reacts with carbonate ions, present in the melt, to form peroxide and/or superoxide ions, depending upon the cations present in the melt. The peroxide species is dominant in a Li-rich melt, whereas the superoxide species is dominant in a $\mathrm{K}$-rich melt. Both the peroxide and the superoxide ions may be present in the eutectic mixture of $62 \mathrm{~mol} \% \mathrm{Li}_{2} \mathrm{CO}_{3}$ and $38 \mathrm{~mol} \% \mathrm{~K}_{2} \mathrm{CO}_{3}$ (eutectic temperature $=488^{\circ} \mathrm{C}$ ), which is used as an electrolyte in the molten carbonate fuel cell. When the peroxide and the superoxide ions are present simultaneously in the electrolyte, the oxygen reduction mechanism may be a combination of the reaction mechanisms proposed earlier. The formation of the superoxide species is favored by the increase in the cationic radius (or acidity) of the melt, i.e. $\mathrm{C}_{\mathrm{O}_{i}^{-}}$- decreases in the order $\mathrm{K}_{2} \mathrm{CO}_{3}>\mathrm{Na}_{2} \mathrm{CO}_{3}>\mathrm{Li}_{2} \mathrm{CO}_{3}$. The superoxide species is considered to be unstable in a pure lithium carbonate melt (22). In the present w'ork, a pure lithium carionate melt is used as an electrolyte to avoid the complexity of simultaneous presence of the peroxide and the superoxide ions in the melt. Also. the lithium carbonate has the lowest melting point $\left(\sim 723^{\circ} \mathrm{C}\right)$ among the pure alkali carbonates 169,

In the molten carbonate fuel cell. a porous electrode made of lithiated $\mathrm{NiO}$ is usec as a cathode. In order to obtain meaningful electrode kinetic parameters. the 
electrochemical measurements need to be carried out on a smooth $\mathrm{NiO}$ electrode. But, the fabrication of a dense $\mathrm{NiO}$ electrode with a well-defined surface area has posed a formidable challenge. Also, the molten alkali carbonate electrolytes are extremely corrosive and most of the metals including noble metals such as platinum and palladium are unstable $(28,36)$ in these electrolytes and form complex oxides $(37)$. The oxygen reduction reaction has generally been studied on a smooth gold electrode. afier Janz and Saegusa (30) showed that gold is "more noble" than platinum in the molten carbonate electrolyte. Since the main objectives of the present work are to elucidate oxygen reduction reaction and to determine the mass transfer and electrode kinetic parameters, a planar gold foil was used as the working electrode. Also, the catalytic effects of the cathode material in the molten carbonate fuel cell may not be very significant because oxygen reduction kinetics is already activated by the high temperature $\left(\sim 650^{\circ} \mathrm{C}\right)$. Further, Uchida et al. (62) recently showed that the exchange current densities for oxygen reduction in $(\mathrm{Li}-\mathrm{K}) \mathrm{CO}_{3}$ have the same order of magnitude on a smooth gold and $\mathrm{NiO}$-coated gold electrodes.

\section{Oxygen Reduction Kinetics in Lithium Carbonate Melt}

The oxygen reduction reaction in a lithium carbonate melt was first studied by Silakor ct al. (70) using the platinum and palladium electrodes. Lorenz and Janz (71) used a gold wire as the test electrode and found that the oxygen reduction mechanism is not the same as that occur at the platinum and palladium electrodes. This discrepancy. can be attributed to corrosion of the platinum and palladium metals in molten alkali carbonates $(36,28)$. They attributed the cathodic current at low overpotentials to the reduction of both oxygen and carbon dioxide to form carbonate ions (Egn. [40]). which was proposed by Stepanor and Trunor (35):

$$
1 / 2 \mathrm{O}_{2}+\mathrm{CO}_{2}+2 \mathrm{e}^{-}=\mathrm{CO}_{3}^{2-}
$$

The direct oxygen reduction reaction (Eqn. (41]) was proposed for the cathodic curreni at overpotentials more negative than $-0.3 \mathrm{l}^{\prime}$ :

$$
1 / 20: 20^{-}=\left(0^{--}\right.
$$


Appleby and Nicholson (46) investigated the oxygen reduction reaction on a submerged gold electrode using steady-state and potential sweep techniques. They specified the difference in electrochemical behavior of the meniscus electrode (e.g., an elec. trode with three-phase boundary) used by previous investigators and fully-immersed electrode. They showed that the diffusion-controlled peak depends on the partial pressures of oxygen $\left(\mathrm{P}_{2}\right)$ and carbon dioxide $\left(\mathrm{P}_{\mathrm{CO}_{2}}\right)$. Based on this observation, they proposed that molecular oxygen reacts with the carbonate ions in the melt to form peroxide ions and carbon dioxide; the peroxide jons are reduced in two electron transfer steps to form oxide ions which recombine with carbon dioxide to form carbonate ions. The reaction mechanism for oxygen reduction in a lithium carbonate melt, proposed by Appleby and Nicholson, is as follow:

$$
\begin{aligned}
1 / 2 \mathrm{O}_{2}+\mathrm{CO}_{3}^{2-} & \rightleftharpoons \mathrm{O}_{2}^{2-}+\mathrm{CO}_{2} \\
\mathrm{O}_{2}^{2-}+\mathrm{e}^{-} & \rightleftharpoons\left(\mathrm{O}^{-}\right)+\mathrm{O}^{2-} \\
\left(\mathrm{O}^{-}\right)+\mathrm{CO}_{2}+\mathrm{e}^{-} & \rightleftharpoons \mathrm{CO}_{3}^{2-} \\
\mathrm{O}^{2-}+\mathrm{CO}_{2} & \rightleftharpoons \mathrm{CO}_{3}^{2-}
\end{aligned}
$$

Overall Reaction

$$
1 / 2 \mathrm{O}_{2}+\mathrm{CO}_{2}+2 \mathrm{e}^{-} \rightleftharpoons \mathrm{CO}_{3}^{2-}
$$

According to this mechanism. the first electron transfer step (Eqn. [43]) is rate determining for a submerged gold electrode and $\left(\mathrm{O}^{-}\right)$is a transient species. The recombination reaction (Eqn. [45]) may be slow and the accumulation of oxide ions at the electrode surface will increase the effective melt basicity of melt in the vicinity of the electrode. In the porous electrode of a molten carbonate fuel cell. the recombination reaction could be the rate determining step. Appleby and Nicholson observed a shift in the peat potential with scan rate and high values of capacitance currents at high scan rates. The latler phenomenon indicates the formation of a solic: oxide layer on the gold electrode surface.

Lu 23 i examined the oxygen clectrode on a fully-immersed gold electrode is a lithium carbonate meli at $750^{\circ} \mathrm{C}$ using potential step and potential swer! 
techniques. He determined the electrode kinetic parameters, exchange current density' and apparent transfer coefficient, as functions of partial pressures of oxygen and carbon dioxide. The exchange current density $\left(38.7 \mathrm{~mA} / \mathrm{cm}^{2}\right.$ for oxidant gas of 0.9 atm $\mathrm{PO}_{2}$ and 0.1 atm $\mathrm{P} \mathrm{CO}_{2}$ at $750^{\circ} \mathrm{C}$ ) was determined in this work from the potential step data and was found to be about two order of magnitude higher than that $\left(0.34 \mathrm{~mA} / \mathrm{cm}^{2}\right)$ obtained by Appleby arid Nicholson (46), who used the potential sweep technique. Lu concluded that the exchange current density determined from the potential sweep data is inherently underestimated. He also showed that the neutralization reaction (Eqn. [45]) is slow. The rate constant of the recombination reaction was shown to increase with temperature and the activation energy of this reaction was determined to be about $19.1 \mathrm{~kJ} \mathrm{~mol}^{-1}$. Lu also showed that the oxide ions produced by oxygen reduction, during the steady state measurements and potential sweep, may accumulate at the electrode-electrolyte interface causing an increase in the effective basicity of the melt at the interface; this increase in the basicity at the interface shifts the electrode potential in the negative direction. Lu determined the reaction orders of the exchange current density to be about +0.15 for partial pressure of oxygen and -0.10 for carbon dioxide; these values of the reaction orders cannot be explained by any of the reaction mechanisms proposed in the literature.

Adanuvor of al. (64) simulated the oxygen reduction reaction on a rotating disk electrode for different cations present in the melt and concluded that melts with high Li-content should yield the highest electrode kinetic rates. Ramaswami (65) investigated the oxygen reduction in lithium carbonate melt using a rotating disk electrode made of gold and linear sweep voltammetry. He determined the diffusion coefficient and the concentration of the peroxide ions as a function of partial pressure of oxygen at $800^{\circ} \mathrm{C}$ and $0.01 \mathrm{~atm}$ partial pressure of carbon dioxide. from the limiting currents and the results of potential step measurements. The diffusion coefficient of the peroxide ions was estimated to be about $3.3 \times 10^{-6} \mathrm{~cm}^{2} \mathrm{~s}^{-1}$ and the value of the diffusion coefficient was found to be independent of the concentration of the peroxide ions. Ramasuami also determined the rate constant of the recombination reaction (Eqn. (45]) by lis: analysis of the potential response to oxide addition. 
The recombination rate constant for lithium carbonate melt at $800^{\circ} \mathrm{C}$ is about $4.1 \times 10^{-3} \mathrm{~s}^{-1}$.

These studies show that (i) the reaction mechanism for oxygen reduction in molten alkali carbonates is not well understood, even for the simplest melt like lithium carbonate where only the peroxide species is present, and (ii) the experimental data could not be explained by the mechanisms available in the literature. In the present work the oxygen electrode reaction in lithium carbonate melt on a fully-immersed gold electrode is examined by electrochemical impedance spectroscopy and cyclic voltammetry.

\section{Experimental Setup}

The experimental setup to investigate the electrode kinetics of oxygen reduction in molten alkali carbonate electrolytes is shown, schematically, in Fig. 2. The experimental setup is similar to that used by other researchers $(43,46,23)$ to study oxygen reduction kinetics in molten carbonate electrolyte. The experimental setup consists of the following: (i) high temperature furnece system; (ii) electrochemical cell assembly; (ii) gas flow measurement/purification system; and (iv) electrochemical measu ement system.

\section{High Temperature Furnace System}

This system consisted of (a) a three-zone, split-type. tubular furnace with an individual thermocouple for each zone, (b) a temperature control system with three microprocessor-based controllers and display devices, (c) outer alumina tube for the controlled environment around the electrochemical cell, and / $d$ i the stainless steel header

A three zone (each zone 6" long) split-tube furnace (Model 3210) rated. for a maximum temperature of $1200^{\circ} \mathrm{C}$. was used to heat the electrochemical cell. Each heating zone was provided with a thermocouple (Type $h$ Chromel/Alumel) and a microprocessor-based controller for separate control to obtain uniform temperature distribution in the electrochemical cell. The electrochemica! coli was hepi in the 


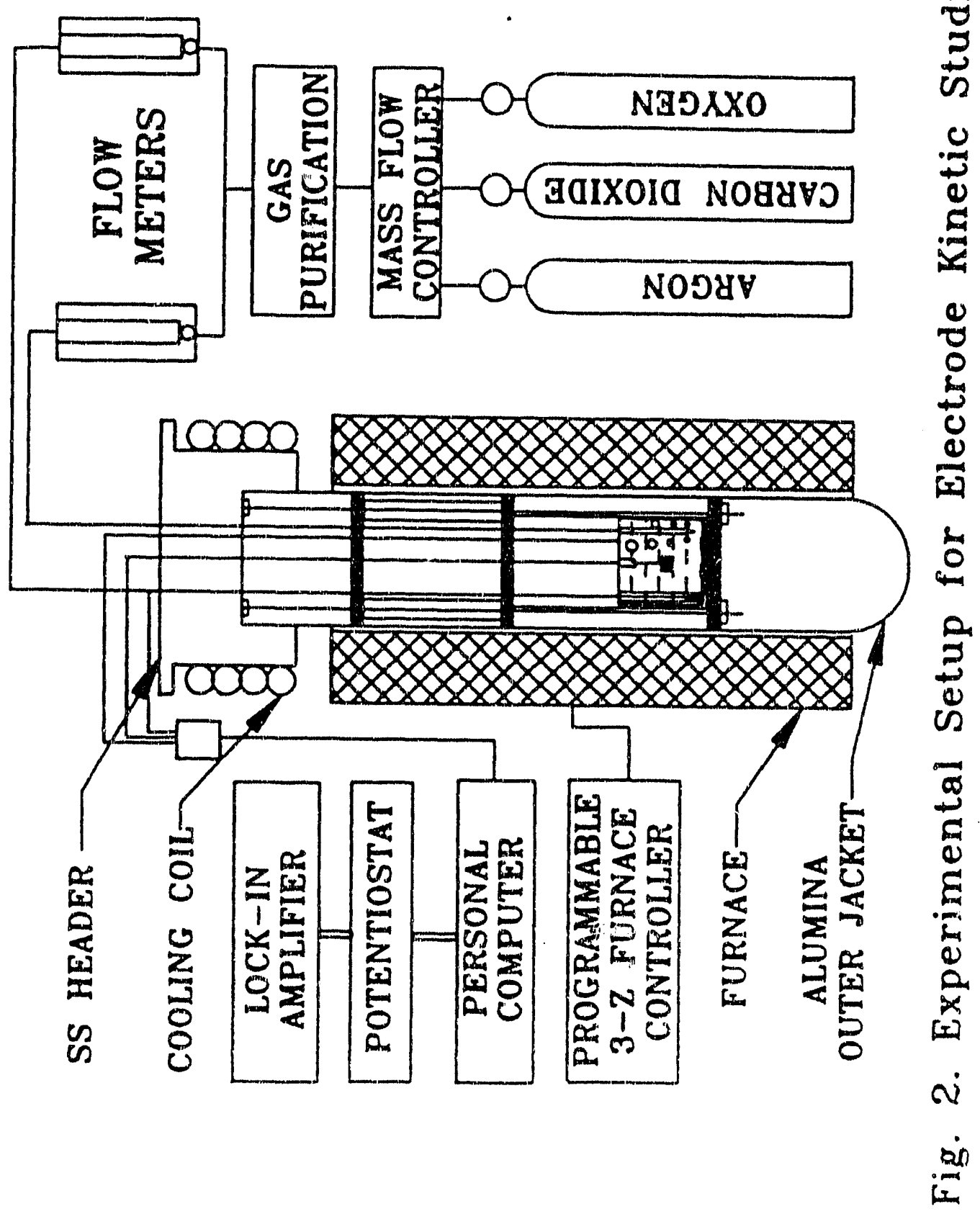


central zone of the furnace. The stainless steel header, shown in Fig. 2, served several purposes. Firstly, the electrochemical cell was suspended from its bottom into the outer alumina tube which was used as an outer jacket in the tube furnace. Secondly, the electrodes, thermocouple, and gas inlet-outlet tubes were fitted by "O" rings through the header. Lastly the header served as a croling device to protect the fittings. The electrochemical cell was suspended from a stainless steel header using alumina tubings and an alumina bottom plate connected by the gold wires. Several pierced alumina baffles with spacers were used to decrease the convective heat transfer in order to minimize the temperature gradient within the cell. The cell temperature was monitored by Type $\mathrm{K}$ Chromel-Alumel thermocouple (Omega) enclosed in a closed end alumina tube, which was firmly pressed against the bottom of the cell. The electrochemical cell and the hanging assembly were enclosed by an outer alumina jacket. The alumina jacket (outer diameter $6.25 \mathrm{~cm}$ and length 76 $\mathrm{cm}, \mathrm{McDanel}$ Refractory Co.) was held by the header using an " $\mathrm{O}$ " ring so that the electrochemical cell assembly was hermetically sealed. The " $O$ " rings used were made of Viton material (National O-rings/Technical Sales Inc.) which could withstand high temperature. The stainless steel header also had a cooling coil to protect the "O" rings.

\section{Electrochemical Cell Assembly}

The electrochemical cell was made of a recrystallized alumina cylinder of $99.8 \%$ purity; obiained from McDanel Refractory Co., with a capacity of about $90 \mathrm{~cm}^{3}$. The working electrode was made of a submerged gold flag $(0.0025 \mathrm{~cm}$ thick) and geometrical area 0 : about one square centimeter $(0.7 \mathrm{~cm} \times 0.7 \mathrm{~cm})$. It was connected to a gold current collector $(0.05 \mathrm{~cm}$ diameter) by a thin gold wire to minimize the meniscus effect 146. 72 ) because the presence of a meniscus modifies the electrochemical response considerably (65. 73). The counter electrode consisted of a large gold foil which was used as an inner liner of the cell to ensure uniform current distribution. The current collectors of the working and the counter electrodes were encased by alumina tubings (diameter $0.63 \mathrm{c}^{\circ} \mathrm{cm}$ ) and the tubings were sealed outside the stainless steel header by 
Swagelock fittings. The reference electrode was also made of a gold foil, but encased in an alumina tube (diameter $0.635 \mathrm{~cm}$ ) which was pressed against the bottom of the electrochemical cell. The Puratronic grade (99.99\%) gold foils and wires were obtained from Johnson Matthey/ÆSAR Group.

\section{Gas Flow Measurement/Purification System}

Individual mass flow controllers/meters (HFC-202, Teledyne-Hastings Raydist) were used for $\mathrm{O}_{2}, \mathrm{CO}_{2}$ and $\mathrm{Ar}$ gases to provide the gas mixtures of the desired compositions with high accuracy $( \pm 1 \%$ Full Scale). The mass flow controllers were powered by a 4-channel power supply (PR-4A) which was also used for read out. The high purity gases were obtained from Matheson Gas Products and traces of water were removed by passing the blended gas through a column of $5 \AA$ molecular sieves and Drierite (Fisher Scientific). The gas mixture was bubbled into the melt in the vicinity of the working electrode at a flow rate of about $50 \mathrm{~cm}^{3} \mathrm{~min}^{-1}$ through a long alumina tube with four pinholes to form smaller bubbles for enhanced mass transfer. The composition of the gas mixture supplied to the reference electrode compartment was the same as the one used for the working electrode, but at a flow rate of about $5 \mathrm{~cm}^{3}$ $\min ^{-1}$.

\section{Electrochemical Measurement System}

The data acquisition setup consisted of a potentiostat/galvanostat (PAR Model 273). loch-in-amplifier (PAR Model 5301A), personal computer (IBM PS/2). and software (PAR Headstart and Model 378) obtained from EG\&G Princeton Applied Research. This setup was used for cyclic voltammetry and electrochemical impedance measurements.

Prior to the experiment, all metallic and ceramic components were rinsed witl: high purity waler and cleaned with acetic acid and hydrochloric acid. The final washing was carried out by high purity water and ultrasonication. The ultra-high purity ( $18 \mathrm{M} \Omega \mathrm{cm}$ resistivity) water, used for the pretreatment of the cell components. was ohtiained by Nanopure water purification sy'stem. The electrodes, gas sparger. 
and thermocouple in an alumina tube were assembled and fitted through the header by using " $\mathrm{O}$ " rings made of Viton. The electrochemical cell was suspended from the header. The entire assembly was dried at $200^{\circ} \mathrm{C}$ for 24 hours. The high purity (99.999\%) lithium sarbonate (Alfa Products) was carefully weighed and transferred to the electrochemical cell. The outer alumina jacket was then fitted into the header by using a Viton " $\mathrm{O}$ " ring and the entire electrochemical cell assembly was hermetically" sealed. The electrochemical cell assembly was slowly heated $\left(50^{\circ} \mathrm{C} / \mathrm{hr}\right)$ to $350^{\circ} \mathrm{C}$ under an inert (e.g., argon) environment. The electrochemical cell assembly was kept at $350^{\circ} \mathrm{C}$ in a carbon dioxide environment for 24 hours before heating to $750^{\circ} \mathrm{C}$. The electrochemical cell was kept in the carbon dioxide environment for 24 hours at $750^{\circ} \mathrm{C}$. The molten lithium carbonate unuilibrated with the gas mixture of desired composition for at least 12 hours prior to the electrochemicai measurements. The potential difference between the working and the counter electrode was constantly monitored by a multimeter.

\section{Cyclic Voltammetry}

Cyclic voltammetry measurements were made in a quiescent lithium carbonate melt as a function of scan rate for the gas composition of $90 \% \mathrm{O}_{2}$ and $10 \% \mathrm{CO}_{2}$ at $850^{\circ} \mathrm{C}$ (Fig. 3). During the potential scan, gas flow through the sparger was stopped, and the gas was blanketed on top of the electrochemical cell. Between two subsequent potential scans. the electrolyte was equilibrated with the gas mixture for several minutes. The potential scans were carried out between the rest potential $(\sim 0.0 \mathrm{~V})$ of the working electrode and $-0.5 \mathrm{~V}$ vs. the reference electrode. The scan rates were varied from $10 \mathrm{mV} / \mathrm{s}$ to $200 \mathrm{mV} / \mathrm{s}$. During the forward scan, a diffusion-controlled peak. follow'ed by a limiting plateau, was observed. Appleby and Nicholson (46) observed similar behavior in their investigation of oxygen reduction in a pure lithium carbonate melt by potential scan technique. They attributed this behavior to the reduction of peroxide ions. The current densicies in the reverse scan were observed to be less cathodic than those in the forward sweep and for overpotential less negative than -0.1 I positive (anodic) current densities were observed. When the applied 
potential returned to the initial potential, a large anodic current was observed. The anodic current density, observed at the end of the sweep, subsided slowly and reached to zero in few minutes; this anodic current density was proportional to the charge passed in the forward sweep. Lu (23) made a similar observation for oxygen reduction on gold in the eutectic mixture of lithium and potassium carbonates. This behavior is due to the local accumulation of oxide ions which shifts the reversible electrode potential in negative direction. Borucka (74) suggested that the electrode potential for $\left(\mathrm{O}_{2}, \mathrm{CO}_{2} / \mathrm{CO}_{3}^{2-}(\mathrm{Au})\right)$ depends on the local activity of oxide ion at the electrodeelectrolyte interface and that the reversible electrode potential is represented by the Nernst equation:

$$
\mathrm{E}_{\mathrm{O}_{2}, \mathrm{CO}_{2} / \mathrm{CO}_{3}^{2-}}=\mathrm{E}_{\mathrm{O}_{2} / \mathrm{O}^{2-}}+\frac{\mathrm{RT}}{2 \mathrm{~F}} \ln \left(\frac{\mathrm{P}_{\mathrm{O}_{2}}^{1 / 2}}{\mathrm{a}_{\mathrm{O}^{2-}}}\right)
$$

where,

$$
\mathrm{E}_{\mathrm{O}_{2} / \mathrm{O}^{2-}}^{\mathrm{o}}=\mathrm{E}_{\mathrm{O}_{2}, \mathrm{CO}_{2} / \mathrm{CO}_{3}^{2-}}^{\mathrm{o}}+\frac{\mathrm{RT}}{2 \mathrm{~F}} \ln \mathrm{K}_{\mathrm{d}}
$$

$\mathrm{Lu}$ (23) and Ramaswami (65) showed that addition of solid $\mathrm{Li}_{2} \mathrm{O}$ pellet to the molten alkali carbonate electrolyte shifts the potential of the submerged gold electrode in a negative direction, which returns to the original value in a few minutes. The magnitude of the potential shift and time taken to return to the original value depends on the amount of oxide added, gas composition and and cations present in the melt.

As shown in Fig. 3, the peak potential value did not vary with the scan rate. The peak potential was about $40-45 \mathrm{mV}$ negative to the equilibrium potential, which corresponded to RT/2F. indicating that two electrons were involved during oxy'gen reduction reaction. Other researchers $(23,61.65)$ have made similar observation for oxygen reduction in molten alkali carbonates. Appleby and Nicholson (46) observed a negative shift in the peat potential for $\mathrm{O}_{2}$ reduction in pure $\mathrm{Li}_{2} \mathrm{CO}_{3}$ which may. have been due to the uncompensated electrolyte resistance. The uncompensatec electrolyte resistance causes the peat potential $\left(E_{p}\right)$ to be a function of the scan rale and shifts the peati potential in a regative direction with an increase in the scan rate even for a reversible electrode reaction (75). Appleby and Nicholson (46. 


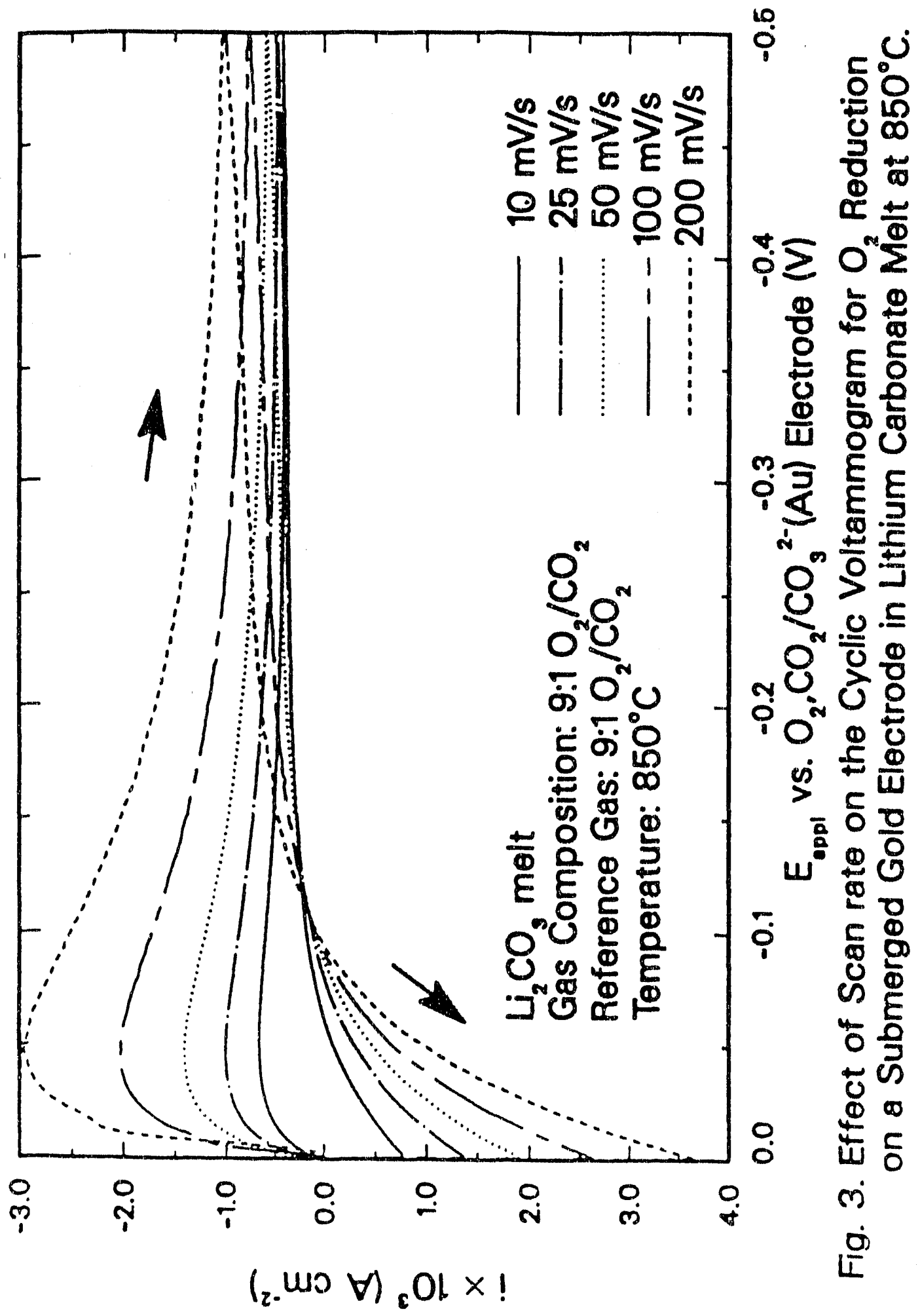


suggested that the diffusion-controlled wave for oxygen reduction in $\mathrm{Li}_{2} \mathrm{CO}_{3}$ melt can be described by the case of constant product activity because the final product is the carbonate ions. Berzins and Delahay (76) have solved the boundary value problem of continuously changing potential applied to the electrochemical system with the following conditions: (i) electrochemically reversible (very fast) reaction; (ii) linear diffusion; and (iii) the product activity is invariant and equal to unity (e.g., metal deposition). They derived the following expression for the current response as a function of potential sweep.

$$
i=\frac{2}{\pi^{1 / 2}} \frac{(\mathrm{nF})^{3 / 2}}{(\mathrm{RT})^{1 / 2}} \mathrm{C}_{\mathrm{O}} \mathrm{D}_{\mathrm{O}}^{1 / 2} \mathrm{v}^{1 / 2} \Phi\left[\left(\frac{\mathrm{nF}}{\mathrm{RT}} \mathrm{t}\right)^{1 / 2}\right]
$$

where, $\mathrm{i}$ is the current density, $\mathrm{n}$ is the number of electrons involved in the electrochemical reaction, $v$ is the scan rate, and $D_{O}$ and $C_{O}$ are the diffusion coefficient and the bulk concentration of the diffusing species, respectively. The function $\Phi[\lambda]$ is represented by the following expression (77):

$$
\Phi[\lambda]=\exp \left(-\lambda^{2}\right) \int_{0}^{\lambda} \exp \left(\mathrm{z}^{2}\right) \mathrm{d} z
$$

where $\mathrm{z}$ is an auxiliary variable. The function $\Phi$ has a maximum value of 0.541 when the argument $\lambda$ is 0.924 (78) and the peak current density is

$$
i_{p}=0.61 \frac{(\mathrm{nF})^{3 / 2}}{(\mathrm{RT})^{1 / 2}} \mathrm{C}_{\mathrm{O}} \mathrm{D}_{\mathrm{O}}^{1 / 2} \mathrm{v}^{1 / 2}
$$

According to Eqn. [51], the peak current density $\left(i_{\mathrm{p}}\right)$ should vary linearly with the square root of the scan rate $\left(r^{1 / 2}\right)$. The slope of this plot is proportional to $D_{O}^{1 / 2} C_{O}$ and knowledge of one of these quantities will yield the other. The linear behavior of in $1 \%, 1^{1 / 2}$ and invariance of the peak potential with the scan rate indicated that the oxygen reduction on a submerged gold electrode in a pure lithium carbonate is "reversibice" uf $10200 \mathrm{mV} / \mathrm{s}(\pi 9)$.

\section{Electrochemical Impedance Spectroscopy}

Electrociemical impedance analysis is a powerful spectroscopic technique based on the same principle that is fundamental to process control. When a linear sy'stem 
is perturbed by an excitation function (e.g., sinusoidal voltage signal), the response (current) is related to the input signal by a transfer function (impedance). The transfer function, also known as an impulse response function, describes the dynumic characteristics of the linear system. The system is perturbed by imposing a small amplitude, sinusoidal voltage signal of frequency $\omega$. The system respunds to this alternating voltage signal by relaxing to a new pseudo-steady state. The resultant current signal will have the same frequency $\omega$, but an amplitude different from the input signal which is phase shifted, provided that higher harmonic response is negligible. The transfer function (impedance) which relates response to the input, is defined as a ratio of the alternating voltage to the alternating current. The electrochemical impedance spectroscopy (EIS) has the following advantages over steady-state and time-domain transient techniques $(80-82)$ : (i) since the amplitude of the sinusoidal, perturbation signal is small, the electrochemical interface is virtually undisturbed, which is not the case when the steady state techniques are used and the electrode electrolyte interface changes due to a very large magnitude of the input signal; (ii) the small amplitude of the perturbation signal makes it possible to treat the output signal by a linear-response analysis. This analysis leads to important simplifications in treating kinetics and diffusion, and (iii) its ability to separate physico-chemical phenomena such as double layer charging, charge-transfer kinetics, and mass transfer process, which is the biggest advantage of the EIS technique.

The electrochemical system is perturbed by superimposing a small amplitude voltage signal. $\tilde{V}^{\prime}=|\tilde{V}| \sin (\omega t)$, of frequency $\omega ;$ the system then responds to this sinusoidal voltage by relaxing to a new pseudo-steady state. The resultant alternating current output. $\tilde{i}=|\bar{i}| \sin (\omega t-\phi)$, will have the same frequency $\omega$, but different amplitude and will be phase shifted from the input signal. The total impedance $\mathrm{Z}$ of the electrochemical system is the ratio of the alternating voltage to the current response and is described by the following equations:

$$
\begin{aligned}
Z & =\frac{\tilde{r}}{\bar{i}} \\
& =|Z| \exp (j \omega) \\
& =Z^{\prime}-j Z^{\prime \prime}
\end{aligned}
$$


The rnagnitude of the total impedance

$$
\begin{aligned}
|Z| & =\frac{|\widetilde{V}|}{\widetilde{\mid i} \mid} \\
& =\sqrt{\left(Z^{\prime}\right)^{2}+\left(Z^{\prime \prime}\right)^{2}}
\end{aligned}
$$

is expressed in $\Omega-\mathrm{cm}^{2}$, and the phase shift between the current and the potential is given by

$$
\phi=\arctan \left(\frac{Z^{\prime \prime}}{Z^{\prime}}\right) .
$$

The impedance analysis was carried out by using the equivalent circuit model shown in Fig. 4. This model is referred to as the Randles-Ershler equivalent circuit model $(83,84)$ and consists of two parallel paths for the two parallel processes occurring at the electrode-electrolyte interface. These processes are double layer charging and faradaic charge transfer. The faradaic impedance consists of the charge transfer resistance and the diffusional impedance in series. The uncompensated resistance between the reference and the working electrodes is given by $R_{s}$ which is in series with the rest of the circuit.

Impedance analysis by the Randles-Ershler equivalent circuit model is based on the following assumptions $(80,82)$ : (i) linearized current-potential characteristic is applicable because the amplitude of the sinusoidal perturbation signal is small and impedance measurements were made at the equilibrium potential of the working electrode: (ii) semi-infinite boundary condition for the mass transfer (i.e.. in the region far away. from the electrode. the bulk concentrations of the species are unperturbed!: (iii) uniform current distribution on a planar working electrode (i.e.. the working electrode is large enough so that deviations from homogeneity of the electric field at the edges is negligible and the counter electrode completely surrounds the working electrode): (iv) a priori separation of the faradaic process and the double layer structurc (i.e.. the faradaic impedance and the double layer reactance are independent of each other): (v) only the fundamental harmonic respronse is considered (i.e.. the amplitude of the perturbation signal is small enough. so that the higher harmonic response. due to the dependence of the double byer capacitance on a volt age acrose 


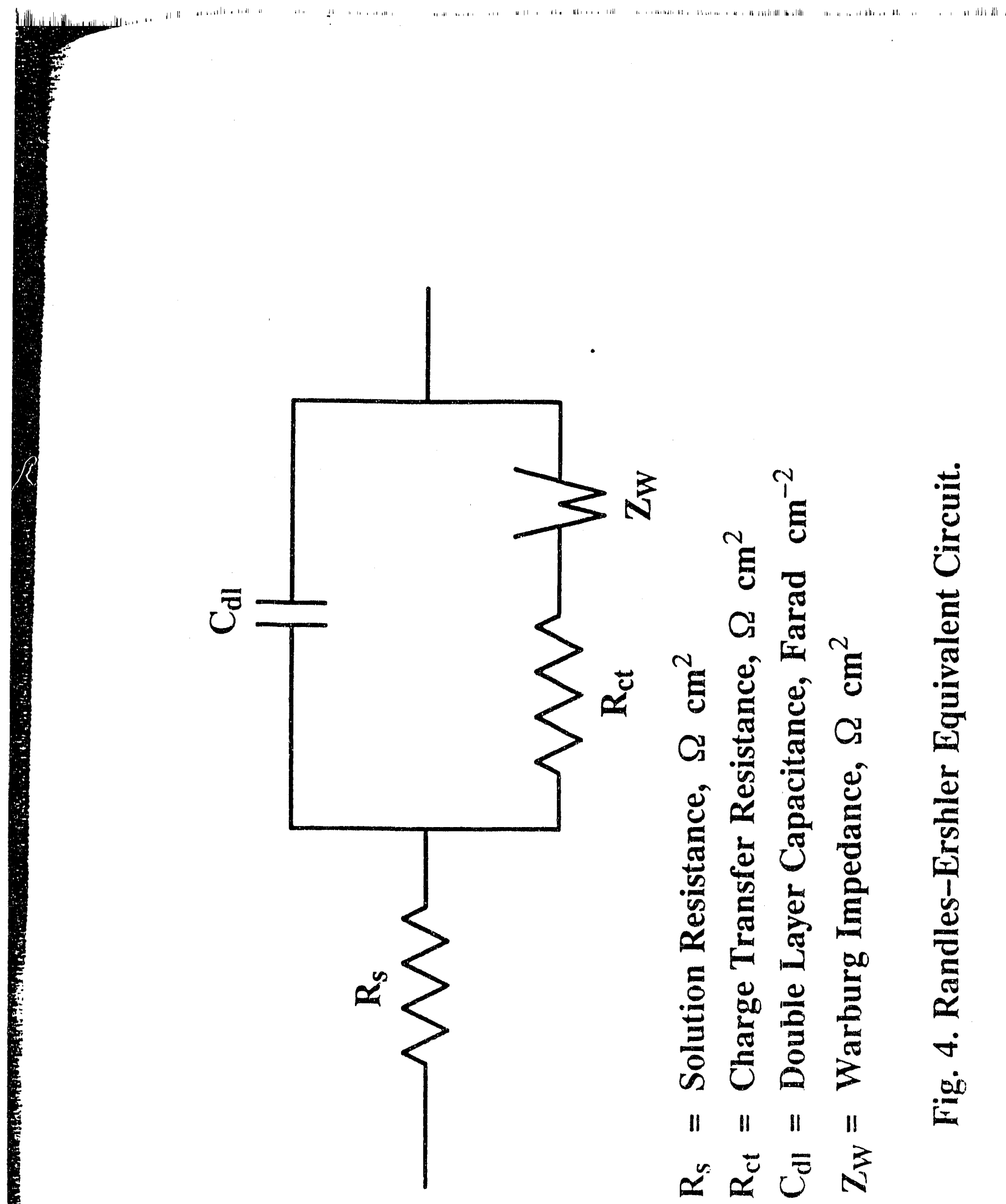


the interface and the exponential dependence of the faradaic current on the surface overpotential, is negligible); (vi) mass transfer is due to diffusion only (i.e., negligible influence of migration and convection); (vii) frequency dispersion of the double layer capacitance is negligible and (viii) charge transfer takes place at the interface where there is no specific adsorption.

The expressions for the real $\left(Z^{\prime}\right)$ and the imaginary $\left(Z^{\prime \prime}\right)$ part of the total impedance $(Z)$ are as follow (82):

$$
\begin{aligned}
Z & =R_{s}+\frac{1}{\left[\left(R_{c t}+Z_{W}\right)^{-1}+j \omega C_{d l}\right]} \\
& =Z^{\prime}-j Z^{\prime \prime}
\end{aligned}
$$

where,

$$
\begin{aligned}
& \mathrm{Z}^{\prime}=\mathrm{R}_{\mathrm{s}}+\frac{\mathrm{R}_{\mathrm{ct}}+\sigma / \sqrt{\omega}}{\left(\mathrm{C}_{\mathrm{dl} l} \sigma \sqrt{\omega}+1\right)^{2}+\omega^{2} \mathrm{C}_{\mathrm{dl}}^{2}\left(\mathrm{R}_{\mathrm{ct}}+\sigma / \sqrt{\omega}\right)^{2}} \\
& \mathrm{Z}^{\prime \prime}=\frac{\omega \mathrm{C}_{\mathrm{dl}}\left(\mathrm{R}_{\mathrm{ct}}+\sigma / \sqrt{\omega}\right)^{2}+\sigma / \sqrt{\omega}\left(\mathrm{C}_{\mathrm{dl}} \sigma \sqrt{\omega}+1\right)}{\left(\mathrm{C}_{\mathrm{d} l} \sigma \sqrt{\omega}+1\right)^{2}+\omega^{2} \mathrm{C}_{\mathrm{dl}}^{2}\left(\mathrm{R}_{\mathrm{ct}}+\sigma / \sqrt{\omega}\right)^{2}}
\end{aligned}
$$

The coinplex plane impedance plot fo: a quasi-reversible reaction is shown schematically in Fig. 5. The impedance spectrum distinguishes various phenomena because of the variation in the relaxation times of these processes. The complex plane plot yields information on phenomena such as double layer charging, charge-transfer reactions, ohmic resistance, and mass transfer process in the electrolyte. Two regions of interest are defined by the conditions: $\omega \rightarrow 0$ and $\omega \rightarrow \infty$.

As $u \rightarrow 0$, the Eqns. [56] and [57] approach the following limiting forms:

$$
\begin{aligned}
& Z^{\prime}=R_{s}+R_{c t}+\sigma / \sqrt{\omega^{\prime}} \\
& Z^{\prime \prime}=\sigma / \sqrt{\omega}+2 \sigma^{2} C_{\mathrm{d} l}
\end{aligned}
$$

Wincli upon elimination of $\omega$ yields

$$
Z^{\prime \prime}=Z^{\prime}-R_{s}-R_{c t}+2 \sigma^{2} C_{d i}
$$

Hence at low frequencies the complex plane plot yields a straight line of $45^{\circ}$ stone whose high-frequency intercept on the real axis is $R_{s}+R_{c l}-2 \sigma^{2} C_{d}$. 

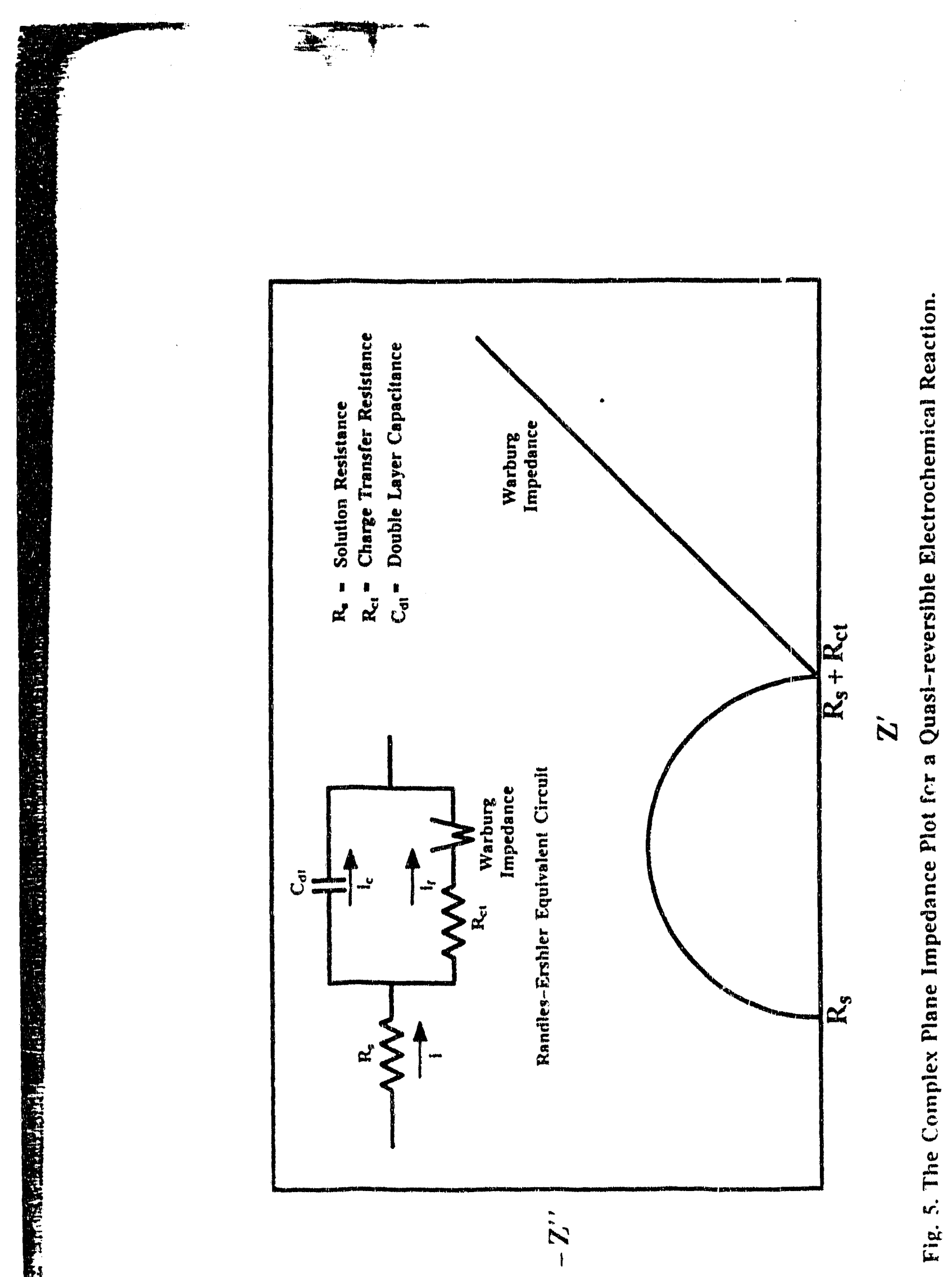
In the second case $u \rightarrow \infty$ and the real and imaginary components of the total impedance attain their limiting values,

$$
\begin{aligned}
Z^{\prime} & =R_{s}+\frac{R_{c t}}{\left(1+\omega^{2} C_{d !} R_{c t}^{2}\right)} \\
Z^{\prime \prime} & =\frac{\omega C_{d !} R_{c t}^{2}}{\left(1+\omega^{2} C_{d l} R_{c l}^{2}\right)}
\end{aligned}
$$

Again, elimination of frequency yields a following expression:

$$
\left(Z^{\prime}-R_{s}-\frac{R_{c t}}{2}\right)^{2}+\left(Z^{\prime \prime}\right)^{2}=\left(\frac{R_{c t}}{4}\right)^{2}
$$

Hence a plot of $Z^{\prime}$ vs. $Z^{\prime \prime}$ gives a semicircle centered at $Z^{\prime}=R_{s}+R_{c t} / 2$ and $Z^{\prime \prime}=0$ and having a radius of $R_{c t} / 2$.

Since oxygen reduction in molten carbonate is very facile, the charge transfer resistance is much smaller compare to the Warburg impedance and the ohmic resistance and the semicircular region is not well defined. Impedance analysis based on the Randles-Ershler equivalent circuit model estimates four parameters, namely, the charge transfer resistance $\left(R_{c t}\right)$, double layer capacity $\left(C_{d l}\right)$, Warburg coefficient $(\sigma)$, and solution resistance $\left(R_{s}\right)$.

\section{Impedance Measurements and Analyses}

The wide range of frequency, from $0.05 \mathrm{~Hz}$ to $10 \mathrm{kHz}$, was used for the small signal perturbation because the capacitive effect attributed to the double layer is significani at high frequency whereas the mass transfer related (Warburg) impedance is dominant at low frequency.

The impedance measurements for frequencies higher than $5 \mathrm{~Hz}$ were carried out using the Phase Sensitive Detection (PSD) techinique with a loch-ill-amplifier and a potentiostat. In the Phase Sensitive Detection rechnique. the impedances. are measured in the frequency domain: the voltage excitation signat is applied simultaneousiy 10 the electrochemical cell and a reference channel. The cell response fcurrent signali is compared with the perturbing signal. using a phase sensitive 
detector. Usually it is not possible to measure a cell impedance by the PSD technique when the excitation signal frequency is below $1 \mathrm{~Hz}$. Hence, for the perturbation signal of frequency below $5 \mathrm{~Hz}$, the cell impedance was measured by the Fast Fourier Transform (FFT) technique using a personal computer and a potentiostat.

The FFT is a time domain technique in which a digitally generated pseudorandom white noise signal (i.e, the algebraic sum of many individual wave forms of equal amplitude but having a different frequency and phase characteristics) is used as a perturbing signal and the complex response to this signal is resolved by an inverse Fast Fourier Transform into discrete frequency data. The FFT technique has a major advantage over frequency domain methods for low frequency measurement because the data can be obtained considerably faster. The low frequency measurements (below. $5 \mathrm{~Hz}$ ) reported here are average of 15 data cycles to improve the accuracy of the data by averaging out the noise interference.

The amplitude of a perturbation signal needs to be small to ensure linear response of the electrochemical system i.e., to decrease the influence of higher harmonics on the measured impedance. The lower limit for the amplitude is determined by the signal-to-noise ratio which can be accepted by the measuring instrument, whereas the high limit is determined by the onset of nonlinear distortion $(85,86)$. We investigated the impedance spectra for oxygen reduction, on gold in lithium carbonate melt at $750^{\circ} \mathrm{C}$, as a function of the excitation signal amplitude and observed that the effect of amplitude on the impedance spectra was insignificant when the amplitude of the perturbation signal was varied from 3 to $9 \mathrm{mV}$, indicating that measurements were in the linear domain. Hence. all the measurements reported here were obtained using an excitation signal amplitude of $5 \mathrm{mV}$. The impedance measurements were carried oui at the equilibrium potential over the frequency range of $0.05 \mathrm{~Hz} 1010 \mathrm{kHz}$. The complex plane plot for the impedances measured at $750^{\circ} \mathrm{C}$ and $90 \% \mathrm{O}$; and $10 \% \mathrm{CO}$ : gas composition is shown in Fig. 6. The absence of a semicircle in the complex plane plot indicated fast electrode kinetics (87). In the region of low frequency. the complex plane impedance plot shows a linear behavior with a slope of $45^{\circ}$ due to the mass irausfer related (Warburg impedance (88). The complex plane plot for frequencies 
higher than $100 \mathrm{~Hz}$ is shown in the inset in Fig. 6. In the region of high frequency; the imaginary part of the impedance $\left(Z^{\prime \prime}\right)$ diminished with increasing frequency and approached zero at about $10 \mathrm{kHz}$.

\section{Impedance Analysis Using Complex Plane Plots}

The uncompensated solution resistance was determined to be $0.38 \Omega$ for the impedance spectrum shown in Fig. 6 by the high frequency limits of Eqns. [56] and [57]:

$$
\text { As } \omega \rightarrow \infty
$$

$$
\begin{aligned}
& Z^{\prime}=R_{6} \\
& Z^{\prime \prime}=0
\end{aligned}
$$

The charge transfer resistance, Warburg coefficient, and double layer capacity were determined by the frequency variation of impedance and admittance spectra in a low frequency region.

As $\omega \rightarrow 0$, the Eqns. [56] and [57] approach the following limiting forms:

$$
\begin{aligned}
& \mathrm{Z}^{\prime}=\mathrm{R}_{\mathrm{s}}+\mathrm{R}_{\mathrm{ct}}+\sigma / \sqrt{\omega} \\
& \mathrm{Z}^{\prime \prime}=\sigma / \sqrt{\omega}+2 \sigma^{2} C_{\mathrm{dl}}
\end{aligned}
$$

Using Eqn. [66], the Warburg coefficient $(\sigma)$ was calculated to be $80.7 \Omega \mathrm{s}^{1 / 2}$ from the slope of a $Z^{\prime}$ vs. $\omega^{-1 / 2}$ plot in the low frequency region $(0.15 \mathrm{~Hz}$ to $30 \mathrm{~Hz}$ ), which is shown in Fig. 7. By substituting Eqn. [67] into Eqn. [66], we get:

$$
Z^{\prime \prime}=Z^{\prime}-R_{b}-R_{c t}+\sigma^{2} C_{d l}
$$

The complex plane plot for impedance data in a low frequency region is shown in Fig. 8: slope of this plot is equal to unity and the intercept is expressed by:

$$
\text { intercept }=-\mathrm{R}_{\varepsilon}-\mathrm{P}_{\mathrm{ct}}+\sigma^{2} \mathrm{C}_{\mathrm{d} l}
$$




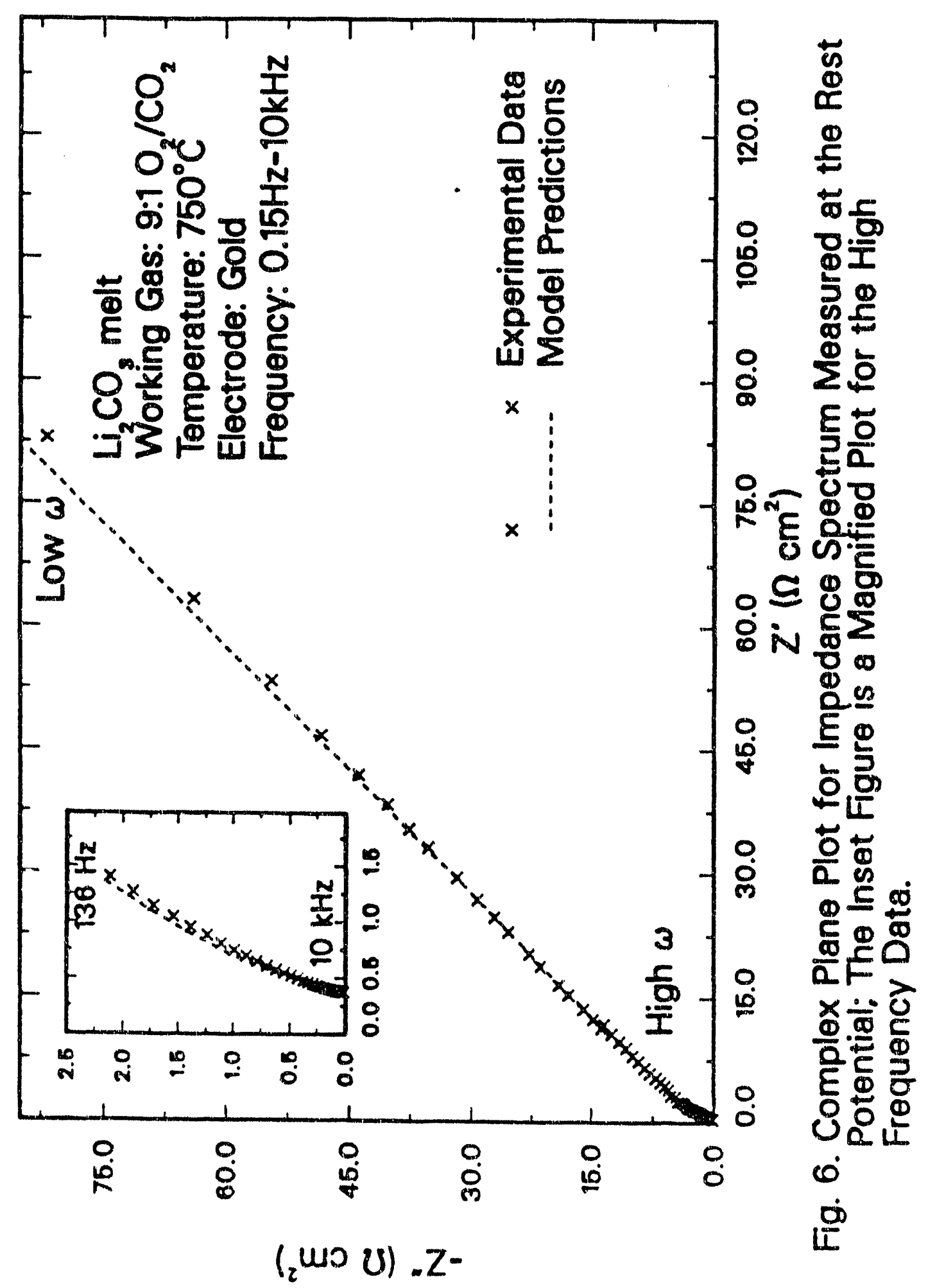




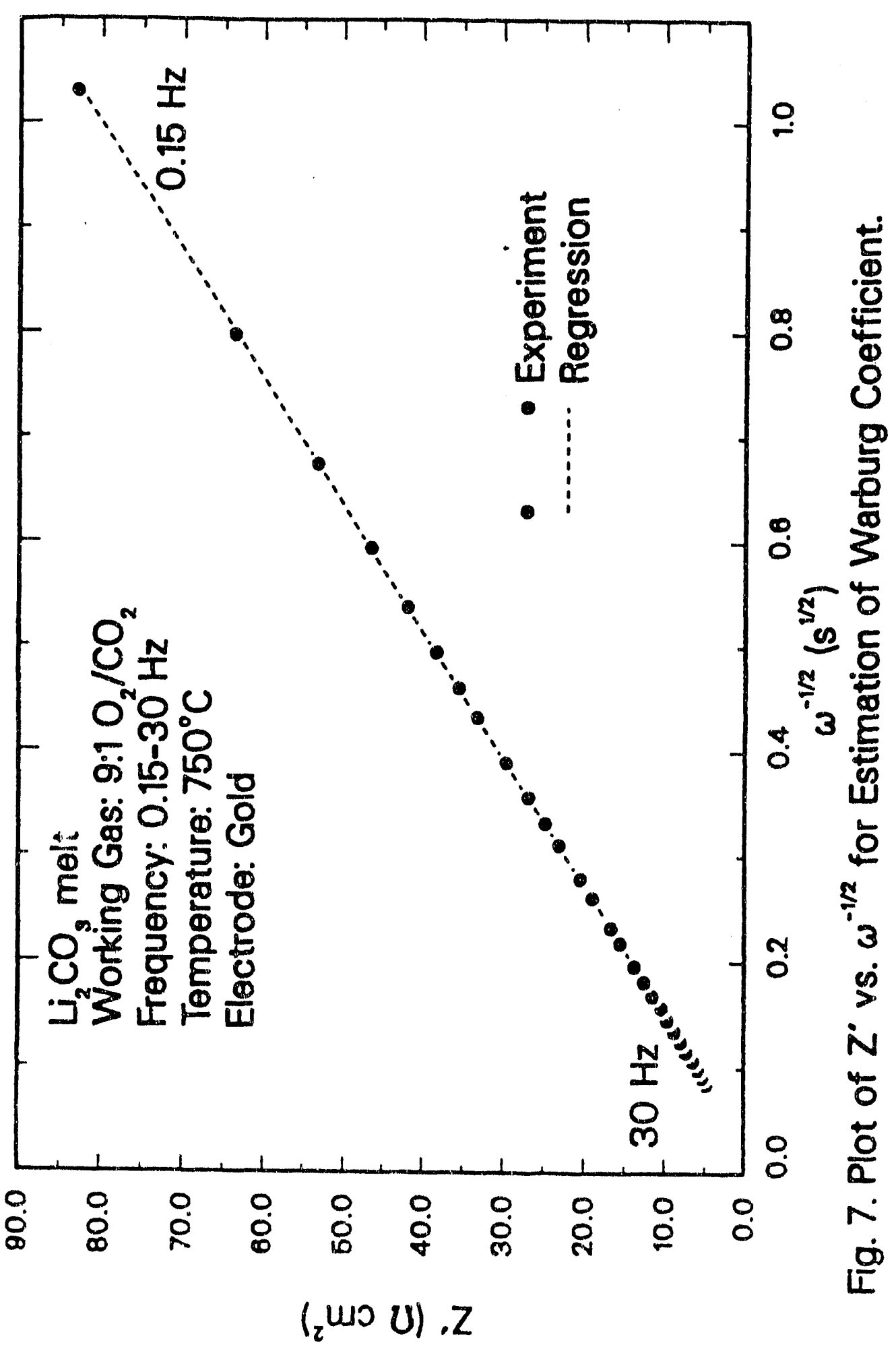


Since the uncompensated solution resistance was already determined from the high frequency limits, the interfacial admittance $\left(Y_{\text {el }}^{\prime}\right)$ can be expressed by the following expressions:

$$
\begin{gathered}
Y_{e l}=Y_{e l}^{\prime}+j Y_{e l}^{\prime \prime} \\
Y_{e l}^{\prime}=\frac{Z^{\prime}-R_{s}}{\left(Z^{\prime}-R_{s}\right)^{2}+\left(Z^{\prime \prime}\right)^{2}} \\
Y_{e l}^{\prime \prime}=\frac{Z^{\prime \prime}}{\left(Z^{\prime}-R_{s}\right)^{2}+\left(Z^{\prime \prime}\right)^{2}}
\end{gathered}
$$

By substituting Eqns. [56] and [57] into Eqns. [71] and [72] and using a parameter $\mathrm{p}=\mathrm{R}_{\mathrm{ct}} / \sigma \omega^{-1 / 2}$

$$
\begin{gathered}
Y_{\mathrm{el}}^{\prime \prime}=\frac{\omega^{1 / 2}}{\sigma} \frac{\mathrm{p}+1}{\mathrm{p}^{2}+2 \mathrm{p}+2} \\
Y_{\mathrm{el}}^{\prime \prime}=\frac{\omega^{1 / 2}}{\sigma} \frac{1}{\mathrm{p}^{2}+2 \mathrm{p}+2}+\omega \mathrm{C}_{\mathrm{dl}}
\end{gathered}
$$

By substituting Eqn.[73] into Eqn. [74]:

$$
Y_{\mathrm{el}}^{\prime \prime}=\frac{Y_{\mathrm{el}}^{\prime}}{p+1}+\omega \mathrm{C}_{\mathrm{dl}}
$$

The parameter $p$ plays an important role in the separation of charge transfer resistance from the Warburg coefficient because it indicates the mode of control over the faradaic impedance: charge transfer resistance is dominant when $\mathrm{p} \rightarrow \infty$ and mass transfer (Warburg) impedance is controlling when $p \rightarrow 0(80)$. Hence $p$ is much less than 1 in the low frequency region where the mass transfer related impedance is dominant, and Eqn. [75] can be approximated by the following expression:

$$
\frac{Y_{\mathrm{el}}^{\prime \prime}}{\omega^{\prime}}=\frac{I_{\mathrm{el}}^{\prime \prime}}{\omega^{\prime}}+C_{\mathrm{dl}}
$$

As shown in Fig. 9, plot of $Y_{e l}^{\prime \prime \prime} / u$ vs. $Y_{e l}^{\prime \prime} / \omega$ showed a linear behavior with a slope of $45^{\circ}$ and double laver capacitance was determined to be $301.4 \mu \mathrm{F} \mathrm{cm}^{-2}$ from the intercept. The charge transfer resistance was calculated to be 1.03 S. by substituting the vajues of $\sigma . R_{x}$ and $C_{d}$ into Eqn. (13). The parameters estimated by this technique are given in Table 3. 


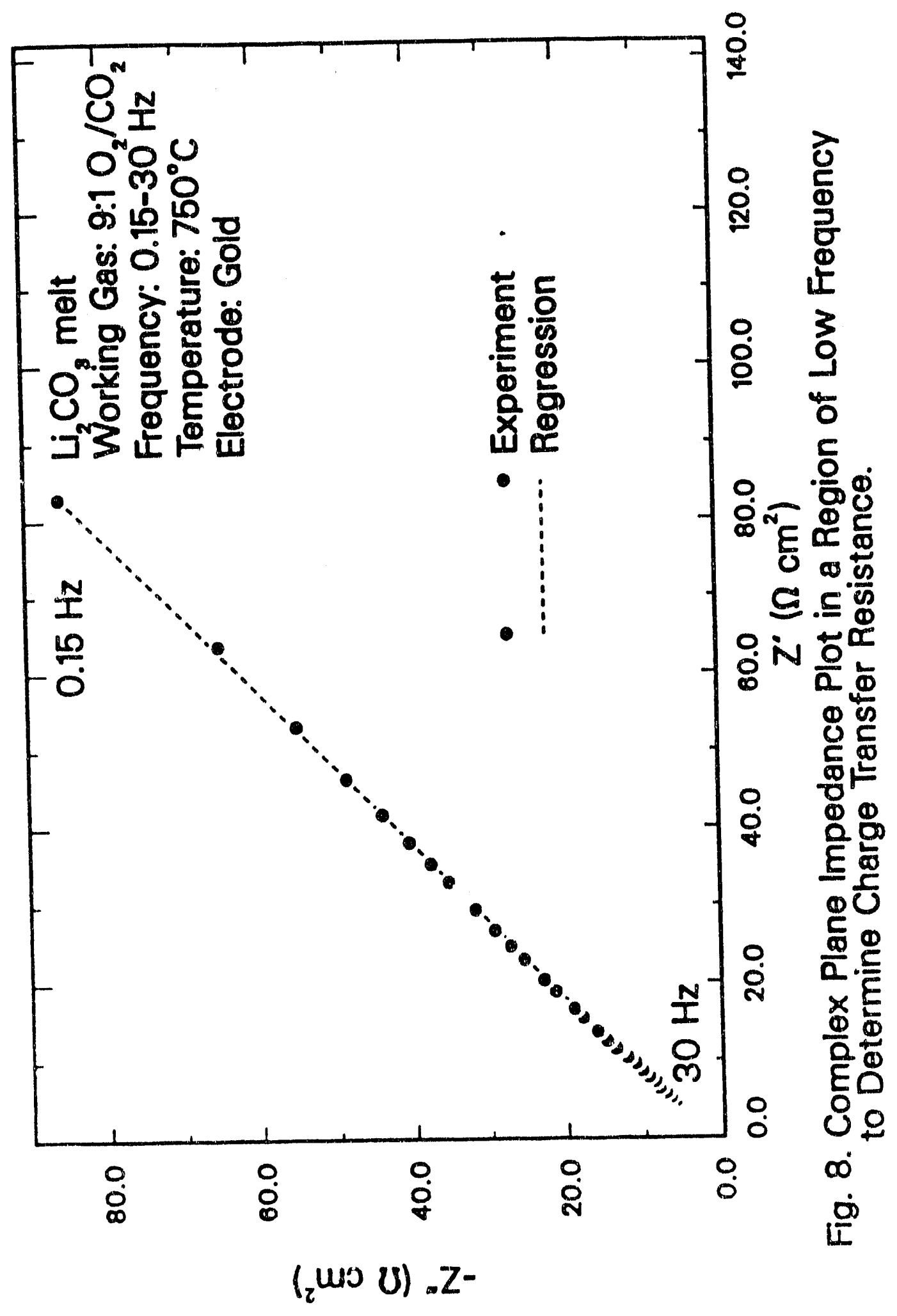




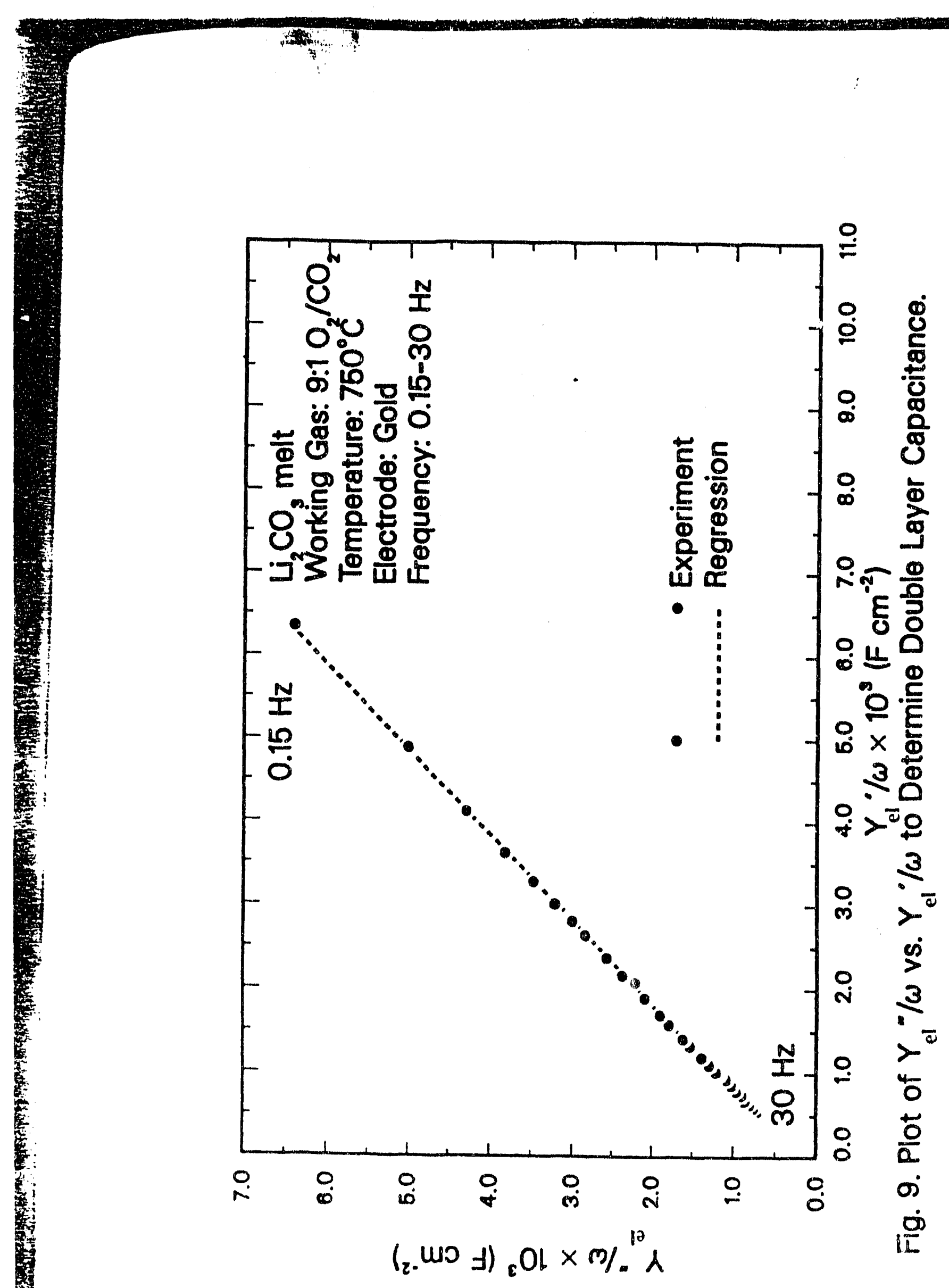


Table 3. Comparison of Kinetic and Mass Transfer Parameters Estimated by Complex Plane Plots and Complex Nonlinear Least Square Technique; Temperature: $750^{\circ} \mathrm{C}$; Gas Composition: $90 \%$ $\mathrm{O}_{2}$ and $10 \% \mathrm{CO}_{2}$.

\begin{tabular}{|c|c|c|c|c|}
\hline Method & $\begin{array}{c}\sigma \\
\Omega \mathrm{cm}^{2} \mathrm{~s}^{-1 / 2}\end{array}$ & $\begin{array}{c}\mathrm{R}_{\mathrm{ct}^{*}} \\
\Omega \mathrm{cm}^{2}\end{array}$ & $\begin{array}{c}\mathrm{C}_{\mathrm{dl}} \\
\mu \mathrm{F} \mathrm{cm}\end{array}$ & $\begin{array}{c}\mathrm{R}_{\mathrm{s}} \\
\Omega \mathrm{cm}^{2}\end{array}$ \\
\hline $\begin{array}{c}\text { Complex } \\
\text { Plane Plots }\end{array}$ & 82.5 & 0.95 & 276 & 0.38 \\
CNLS & $81.3 \pm 2.5$ & $0.95 \pm 0.48$ & $301 \pm 17$ & 0.38 \\
\hline
\end{tabular}


Impedance Data Analysis by Nonlinear Parameter Estimation

A Complex Nonlinear Least Square (CNLS) parameter estimation program (89, - 91) was used with the Randles-Ershler equivalent circuit model (Eqns. [56] and [57]) to analyze impedance spectrum and determine kinetic and mass transfer related parameters. The CNLS program is based on the modified Levenberg-Marquardt algorithm $(92,93)$. The objective function, $f(X)$ which is to be minimized, is the sum of squares of the weighted-residual error between the experimentally observed data and the values predicted by the equivalent circuit model. Mathematically, $f(X)$ is expressed as:

$$
f(X)=\sum_{i=1}^{N}\left[w_{i}^{\prime}\left(Z_{\text {exp }, i}^{\prime}-Z_{\text {mod }, i}^{\prime}\right)^{2}+w_{i}^{\prime \prime}\left(Z_{\text {exp }, i}^{\prime \prime}-Z_{\text {mod }, i}^{\prime \prime}\right)^{2}\right]
$$

where, $\mathbf{X}$ is the vector of the unknown parameters to be evaluated, $Z_{i}^{\prime}$ and $Z_{i}^{\prime \prime}$ are the real and the imaginary parts of the impedance, and $w_{i}^{\prime}$ and $w_{i}^{\prime \prime}$ are the weighting factors for the real and the imaginary parts of the impedance, respectively. In this analysis, it was found that the weighting factor (inverse of the error variance) considerably influenced the accuracy of the parameters estimated from the impedance data. In the CNLS program, the impedance data can be weigheted in various ways such as unit weighting (UWT), modulus weighting (MWT), and proportional weighting (PWT) (94). The UWT means $w_{i}^{\prime}$ and $w_{i}^{\prime \prime}$ are equal to one, and all data are weighted evenly. The MWT means $w_{i}^{\prime}$ and $w_{i}^{\prime \prime}$ are the same and equal to inverse of the modulus $(|Z|)$ of the data points. The PWT means the uncertainties associated with the real and the imaginary components of the data are proportional to their magnitudes. The selection of the weighting was carried out by computer generated impedance spectrum using the Randles-Ershler equivalent circuit model and the parameters estimated by the complex plane plots. The "synthetic" data were obtained by adding random errors. The effect of weighting factor on the accuracy of the estimated parameters was determined for the difierent levels of random errors 1 $1 \%$. $2 \%$. and $5 \%$ of the magnitudel. The accuracy of the estimatd parameters decreased with increase in the magnitude of random error: the error in the estimaled 
parameters was most pronounced for the UWT and the least for the proportional weighting. Hence, the proportional weighting factor was used to estimate the charge transfer resistance, double layer capacity and Warburg coefficient from the impedance data. As shown in a complex plane plot in Fig. 6, the model impedance data, calculated using the estimated parameters and the Randles-Ershler equivalent circuit model (Eqns. [56] and [57]), were consistent with the experimental data. Since the impedance measurements were obtained at the equilibrium potential, the charge transfer resistance can be expressed as follows (80):

$$
\mathrm{R}_{\mathrm{ct}}=\frac{\mathrm{RT}}{\mathrm{nFi_{0 }}}
$$

By using Eqn. [78], the exchange current density for oxygen reduction reaction on a gold electrode was calculated to be $44.0 \mathrm{~mA} \mathrm{~cm}^{-2}$. As shown in Table 1, the parameters estimated by the complex plane plot methods and the CNLS technique are in good agreement. The complex plane plot technique utilizes the impedance data in a low frequency region only, whereas the computer curve fitting CNLS method uses the entire impedance spectrum. Hence, the parameters estimated by the CNLS technique can be expected to be more reliable than those obtained by the complex plane plots.

\section{Conclusions}

The cyclic voltammogram showed a diffusion-limited peak followed by a limiting current plateau. The peak potential did not vary with the scan rate and the peak potential was $\sim 45 \mathrm{~m})^{\prime}$ ( $\mathrm{RT} / 2 \mathrm{~F}$ ) negative of the equilibrium potential. indicating that the oxygen reduction in a pure lithium carbonate melt involves two electrons. The Inear variation of the peak current density with the square root of the scan rate and invariance of the peat potential with respect to the scan rate showed the the oxy'gen reduction reaction in a pure lithium carbonate melt is "reversible" up to 200 $\mathrm{ml} / \mathrm{s}$. Since the complex plane impedance plot did noi show a semicircular relaxation. the electrochemicai inupedance spectrum indicaled that electrode kinetics of oxiges. 
reduction reaction in a pure lithium carbonate melt are very rapid. In a region of low frequency, the complex plane impedance plot showed a linear behavior with a slope of $45^{\circ}$ indicating that the diffusional process is dominant. The electrochemical impedance spectra were analyzed by the complex plane plots (graphical analysis) and CNLS program based on Levenberg-Marquardt algorithm. The electrode kinetic and mass transfer parameters determined by the graphical and CNLS analyses agreed well. The parameters obtained by the CNLS technique not only have better accuracy, but it also provide the confidence limits for the estimated parameters. 


\section{CHAPTER IV}

\section{EFFECTS OF TEMPERATURE}

\section{Introduction}

The oxygen reduction process in molten alkali carbonate electrolyte has been studied for the past 25 years because of its vital role in the performance and stability of the molten carbonate fuel cell. Appleby and Nicholson (45 - 47) examined the oxygen reduction reaction in molten carbonates on a submerged gold electrode using steady state and potential scan techniques. They observed that oxygen reicts with carbonate ions and forms peroxide and superoxide ions and the concentrations of these species depend on the cations present in the melt. In a pure $\mathrm{Li}_{2} \mathrm{CO}_{3}$ or a $\mathrm{Li}$ rich melt the peroxide species is dominant, whereas in a $\mathrm{K}$-rich melt the superoxide species is dominant. Hence, the oxygen reduction mechanism strongly depends on the cations present in the melt. Andersen (22) carried out a thermodynamic study on the chemical equilibria in molten alkali carbonate electrolytes and demonstrated the presence of peroxide ions by the quenching experiments followed by chemical analyses. Vogel et al. (57) studied the $(\mathrm{Li}-\mathrm{K}) \mathrm{CO}_{3}$ eutectic melt at $650^{\circ} \mathrm{C}$, using a rotating gold wire and concluded that superoxide is dominant in this melt and the amount of molecular oxygen in the melt is negligible. White and Twardoch (59) examined the ( $\mathrm{Li}-\mathrm{Na}-\mathrm{K}$ ) $\mathrm{CO}_{3}$ eutectic melt at $680^{\circ} \mathrm{C}$ by cyclic voltammetry, chronopotentiometry; and chronoamperometry and observed the simultaneous presence of peroxide and oxide ions. Dunks and Stelman (53) studied pure sodium carbonate melt at $900^{\circ} \mathrm{C}$ and proposed the presence of percarbonate ions. $L u(23)$ investigated the oxygen reduction reaction in pure $\mathrm{Li}_{2} \mathrm{CO}_{3}$ and a $\mathrm{Li}-\mathrm{K}$ (62 mol\%:38 mol\%) carbonate eutectic mixture using a potential step method. The exchange current density determined by Lu. is two orders of magnitude higher than that observed by Appleby and Nicholson. who used the potential scan technique. But the dependence of oxygen reduction kinetics on partial pressures of oxygen and carbon dioxide observed by Lu could not 
be explained by any of the mechanisms proposed in the literature. Uchida et al. (61) determined the kinetic parameters of oxygen reduction in a $(\mathrm{Li}-\mathrm{K}) \mathrm{CO}_{3}(42.7$ mol\%:57.3 mol\%) eutectic melt on a gold electrode using electrochemical impedance spectroscopy, potential step and coulostatic relaxation methods. They found that the exchange current density was about the same order of magnitude as that observed by Lu. In addition, they concluded that the electrochemical impedance spectroscopy is the most reliable of the three methods for the determination of the kinetic parameters for oxygen reduction in molten carbonates. Uchida et al. (62) examined the oxygen reduction on a lithiated $\mathrm{NiO}$ film, deposited on gold, and $\mathrm{Sb}$-doped $\mathrm{SnO}_{2}$ electrodes in $\mathrm{Li}-\mathrm{K}$ eutectic melt by impedance spectroscopy and coulostatic relaxation techniques. They (63) also determined the temperature dependence of oxygen reduction kinetics on gold in ( $\mathrm{Li}-\mathrm{K}) \mathrm{CO}_{3}$ and determined the activation energies for the kinetic and mass transfer processes.

These studies show that (i) oxygen reduclion kinetics in molten alkali carbonate strongly depends on the cations present in the melt; (ii) the mechanism for the oxygen reduction in molten carbonate is not well understood; and (iii) the results reported in the literature are contradictory. Consequently, in the present work, we used pure lithium carbonate melt to avoid the complexity of simultanecus presence of peroxide and superoxide ions. The oxygen reduction reaction on a sulmerged gold electrode was studied using electrochemical impedance spectroscopy (EIS) and cyclic voltammetry to determine the kinetic and transport parameters. Also, the influence of iemperature on the oxygen reduction kinetics was examined and the apparent activation energies were calculated.

\section{Experimental}

The experimental arrangement and the electrochemical cell assembly used for this work are shown in Fig. 2. The electrochernical cell was made of a recrystallized alumina cylinder of $99.8 \%$ purity obtained from $\mathrm{McDanel}$ Co.. with a capacity of about $90 \mathrm{~cm}^{3}$. The working electrode was made of a submerged gold fiag $10.0025 \mathrm{~cm}$ 
thick), and a geometrical area of one square centimeter, was connected to the gold current collector $(0.05 \mathrm{~cm}$ diameter) by a thin gold wire to minimize the meniscus effect $(46,72)$ because the presence of a meniscus modifies the electrochemical response considerably (73). The counter electrode consisted of a large gold foil which was used as an inner liner of the cell to ensure uniform current distribution. The reference electrode was also a gold foil, but encased in an alumina tube which was pressed against the bottom of the electrochemical cell. The Puratronic grade (99.99\%) gold foils and wires were obtained from Johnson Matthey/ESAR Group.

Digital mass flow controllers/meters manufactured by Teledyne-Hastings Raydist were used to provide the gas mixtures of the desired compositions of $\mathrm{O}_{2}, \mathrm{CO}_{2}$ and $\mathrm{Ar}$, with high precision ( $\pm 1 \%$ Full Scale). The high purity gases were obtained from Matheson Gas Products and the traces of water were removed by passing the blended gas through a column of $5 \AA$ molecular sieves and Drierite (Fisher Scientific). The gas mixture was bubbled into the melt in the vicinity of the working electrode at a flow rate of about $50 \mathrm{~cm}^{3} \mathrm{~min}^{-1}$ through a long alumina tube with four pinholes to form smaller bubbles for enhanced mass transfer. The composition of the gas mixture supplied to the reference electrode compartment was the same as the one used for the working electrode, but at a flow rate of about $5 \mathrm{~cm}^{3} \mathrm{~min}^{-1}$.

The electrochemical cell was suspended from a stainless sieel header using alumina tubings and an alumina bottom plate connected by the gold wires. Several pierced alumina baffles with spacers were used to decrease the convective heat transfer in order to minimize the temperature gradient within the cell. Also a three-zone furnace. with individual microprocessor-based controllers (Applied Test systerns. Inc.: was used to ensure uniform temperature distribution in the cell. The cell temperaiure was monitored by a Chromel-Alumel thermocouple (Omega). enclosed in a ciosed end alumina tube, which was firmly pressed against the bottom of the cell. The eicctroi hemical cell and the hanging assembly were enclosed in an outer alumina jacket. held by the header using an "Or ring so that the electrochemical cell assembly was hermetically sealed. The stainless steel hender also had a cooling coil in protect bine "O" rimgs. 
High purity (99.999\%) lithium carbonate (Alfa Products) was carefully weighed in an alumina crucible and the electrochemical cell assernbly was slowly heated $\left(50^{\circ} \mathrm{C} / \mathrm{hr}\right.$ ) to $350^{\circ} \mathrm{C}$ under an inert (argon) environment. The electrochemical cell assemoly was dried at $350^{\circ} \mathrm{C}$ in a carbon dioxide environment for 24 hours before heating to $750^{\circ} \mathrm{C}$.

The data acquisition setup, which consisted of a potentiostat/galvanostat (PAR Model 273), lock-in-amplifier (PAR Model 5301A), personal computer (IBM PS/2), and software (PAR Headstart and Model 378), supplied by EG\&G Princeton Applied Research, was used for cyclic voltammetry and electrochemical impedance measurements. A wide range of frequency, i.e. $0.05 \mathrm{~Hz}$ to $10 \mathrm{kHz}$, was used for the small signal perturbation to determine the capacitive effect attributed to the double layer which is significant at high frequency and the mass transfer related (Warburg) impedance which is dominant at low frenuency.

The impedance measurements for frequencies higher than $5 \mathrm{~Hz}$ were carried out using the Phase Sensitive Detection (PSD) technique with a lock-jn-amplifier and a potentiostat. In the Phase Sensitive Detection technique, the impedances are measured in the frequency domain and the voltage excitation signal is applied simultaneously' to the electrcchemical cell and a reference channel. The cell response (current signal) is compared with the perturbing signal, using a phase sensitive detector. Usually it is not possible to measure a cell impedance by the PSD technique when the excitation signal frequency is below $1 \mathrm{~Hz}$. Hence, for the perturbation signal of frequency below $5 \mathrm{~Hz}$, the cell impedance was measured by the Fast Fourier Iransform (FFT) technique using a personal computer and a potentiostat.

The FFT is a time domain technique in which a digitally generated pseudo randiom white noise signal (i.e, the algebraic surn of many individual wave forms of equal amplitude but having a different frequency and phase characteristics) is used as a perturbing signal and the complex response to this signal is resolved iy ar inverse Fast Fourie: Transiorn ino discrete frequency data (82). The FFT recimigut has a ma io: advantage aver frenuency domain methods for low frequency 
measurement because the data can be obtained considerably faster. The low frequency' measurements (below $5 \mathrm{~Hz}$ ), reported here are for an average of 15 data cycles in order to improve the accuracy of the data by averaging out the noise interference.

The amplitude of a perturbation signal needs to be small to ensure linear response of the electrochemical system, hence decrease the influence of higher harmonics on the measured impedance. The low limit for the amplitude is determined by the signal-to-noise ratio, which can be accepted by the measuring instrument, whereas the high limit is determined by the onset of nonlinear distortion. The impedance spectra for oxygen reduction on gold in lithium carbonate melt at $750^{\circ} \mathrm{C}$ were obtained as a function of the excitation signal amplitude; it was observed that the effect of amplitude on the impedance spectra was insignificant when the amplitude of the perturbation signal varied from 3 to $9 \mathrm{mV}$, indicating that the measurements were in the linear domain. All the measurements reported here were obtained with the excitation signal amplitude of $5 \mathrm{mV}$.

\section{Electrochemical Impedance Measurements and Analyses}

The temperature dependence of oxygen reduction reaction in lithium carbonate melt was investigated by electrochemical impedance spectroscopy to determine the activation energies of the exchange current density and the Warburg coefficient. The effect of temperature on a plot of phase angle vs. $\log \omega$ is shown in Fig. 10. In the high frequency region. all plots converged to a $0^{\circ}$ phase angle indicating that the solution resistance becomes dominant. At frequencies below $30 \mathrm{~Hz}$, the phase angle approached $-45^{\circ}$. indicating mass transfer impedance was significant. The impedance spectra. obtained as a function of temperature, were analyzed by the CNLS method and the optimized parameters are given in Table 2. The effect of temperature on $Z^{\prime}$ vs. $\omega^{-1 / 2}$ D! $t$ is shown in Fig. 11. In the low frequency region. Fig. 11 show's a linear behavior of $Z^{\prime} \cup w^{-1 / 2}$ plot indicating that the mass transfer impedance is dominant. The Marburg coefficient is proportional to the slope of the lines in Fig. 11. The lines in Fig. 11 indicate that an increase in the temperature decrease the Warburg coefficient. 


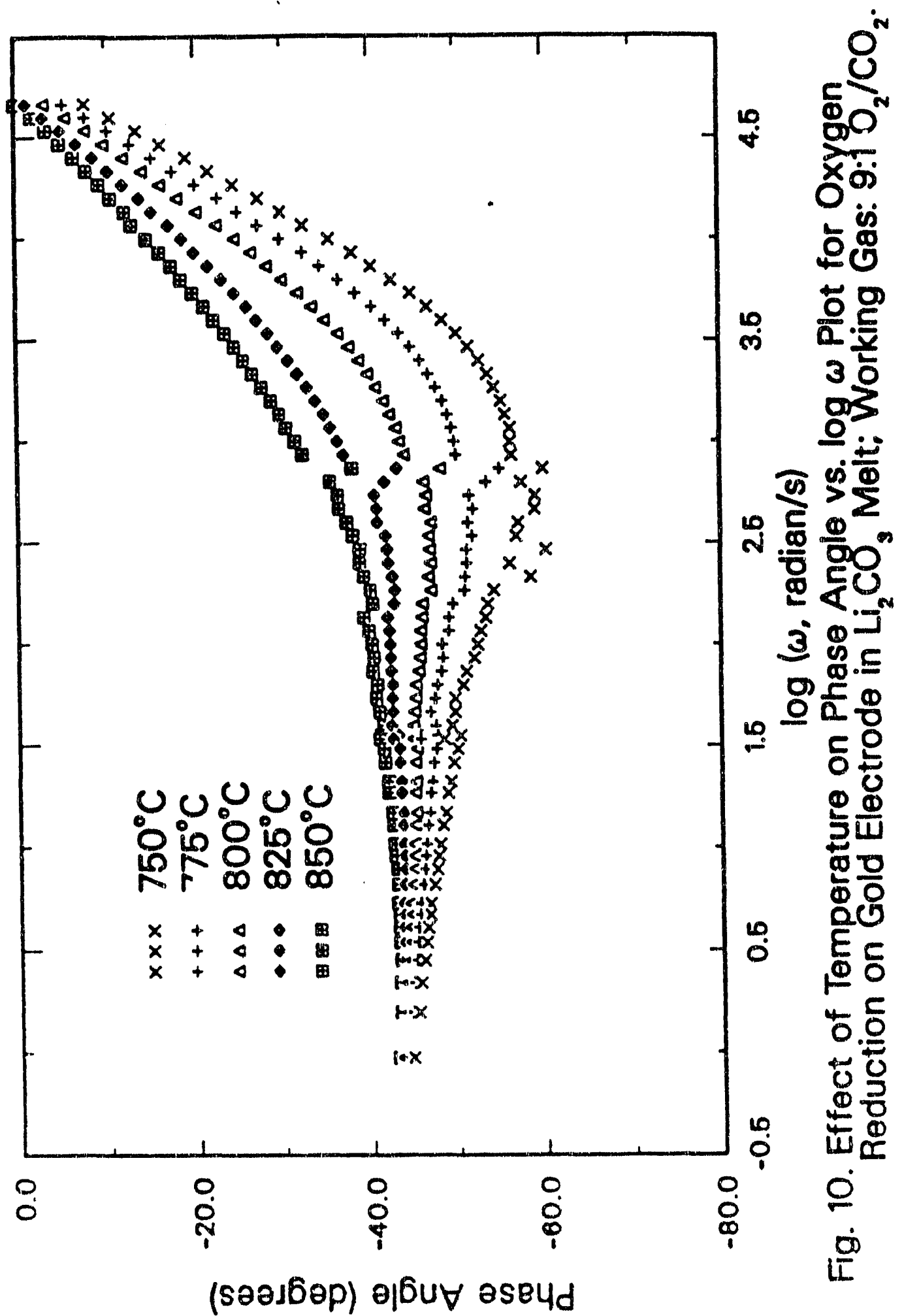




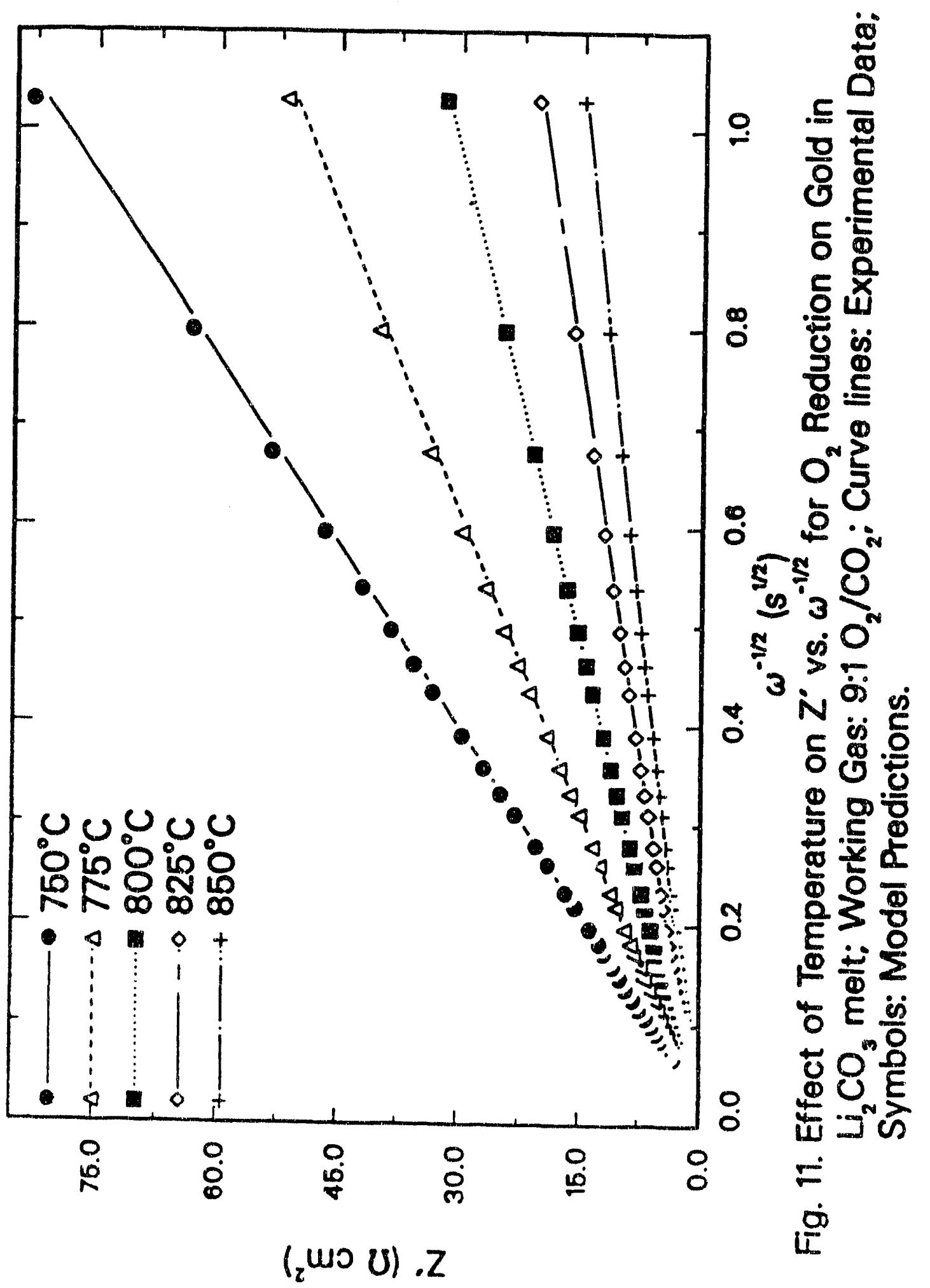


This observation is corroborated, quantitatively, by the estimated parameters shown in Table 4. An increase in temperature from 750 to $850^{\circ} \mathrm{C}$ caused more than a five fold decrease in the Warburg coefficient, whereas the decrease in the charge transfer resistance was about three fold. The double layer capacity value increased with the increase in temperature; a similar trend was observed when the partial pressure of oxygen was increased, while partial pressure of carbon dioxide was kept constant (95). The increase in double layer capacity with temperature may be due to the formation of a solid oxide film on a gold electrode. The effects of temperature on the entire impedance spectrum can be observed by $\log |Z|$ vs. $\log \omega$ plots in Fig. 12. In the high frequency region, $\log |\mathrm{Z}|$ vs. $\log \omega$ plot approached the uncompensated electrolyte resistance, $R_{s}$, which is independent of frequency. In the low frequency region, complete relaxation due to the charge transfer process $\left(\mathrm{R}_{\mathrm{ct}} \mathrm{C}_{\mathrm{dl}}\right)$ is not observed due to the Warburg impedance. As shown in Fig. 12, the experimental and model data were in good harmony for the entire frequency range of the experiment.

Since impedance measurements were obtained at the equilibrium potential, in the absence of DC polarization, the Warburg coefficient is expressed by the following equation $(81)$ :

$$
\sigma=\frac{R T}{n^{2} F^{2} A \sqrt{2}}\left(\frac{1}{D_{O}^{1 / 2} C_{O}}+\frac{1}{D_{R}^{1 / 2} C_{R}}\right)
$$

For oxygen reduction in a lithium carbonate melt, concentration of the peroxide ions $\left(C_{O}\right)$ is much smaller compared to the concentration of the carbonate ions $\left(C_{R}\right)$. Considering that $D_{O}$ and $D_{H}$ are of the same order of magnitude. then $1 / D_{R}^{J / 2} C_{R}$ is negligible compared with $1 / \mathrm{D}_{\mathrm{O}}^{1 / 2} \mathrm{C}_{\mathrm{O}}$. Thus Eqn. 179 ) can be approximated by the foliowing expression:

$$
r=\frac{R T}{n^{2}-F^{2} A \sqrt{2}}\left(\frac{1}{D_{O}^{1 / 2} C_{O}}\right)
$$

The mass transfer parameter. $\mathrm{D}_{\mathrm{O}}^{1 / 2} \mathrm{C}_{\mathrm{O}}$. and the exchange current density values were rakculated using Eqns. (80) and (81). respectively.

$$
R_{1+1}=\frac{R T}{n F i_{1}}
$$


Table 4. Parameters Estimated by Impedance Analysis Using CNLS Program; Gas Composition: $90 \% \mathrm{O}_{2}$ and $10 \% \mathrm{CO}_{2} ; \mathrm{Pa}-$ rameter $\mathrm{R}_{\mathrm{s}}$ : Constant Parameter.

\begin{tabular}{|c|c|c|c|c|}
\hline $\begin{array}{c}\text { Temperature } \\
{ }^{\circ} \mathrm{C}\end{array}$ & $\begin{array}{c}\sigma \\
\Omega \mathrm{cm}^{2} \mathrm{~s}^{-1 / 2}\end{array}$ & $\begin{array}{c}\mathrm{R}_{\mathrm{ct}} \\
\Omega \mathrm{cm}^{2}\end{array}$ & $\begin{array}{c}\mathrm{C}_{\mathrm{d} \mathrm{l}} \\
\mu \mathrm{F} \mathrm{cm}\end{array}$ & $\begin{array}{c}\mathrm{R}_{\mathrm{s}} \\
\Omega \mathrm{cm}^{2}\end{array}$ \\
\hline 750 & $81.3 \pm 2.5$ & $0.95 \pm 0.48$ & $301 \pm 17$ & 0.38 \\
775 & $49.8 \pm 2.0$ & $0.93 \pm 0.35$ & $400 \pm 26$ & 0.38 \\
800 & $30.6 \pm 1.0$ & $0.68 \pm 0.17$ & $506 \pm 29$ & 0.38 \\
825 & $19.2 \pm 0.6$ & $0.40 \pm 0.10$ & $692 \pm 42$ & 0.38 \\
850 & $13.9 \pm 0.3$ & $0.30 \pm 0.05$ & $855 \pm 44$ & 0.39 \\
\hline
\end{tabular}




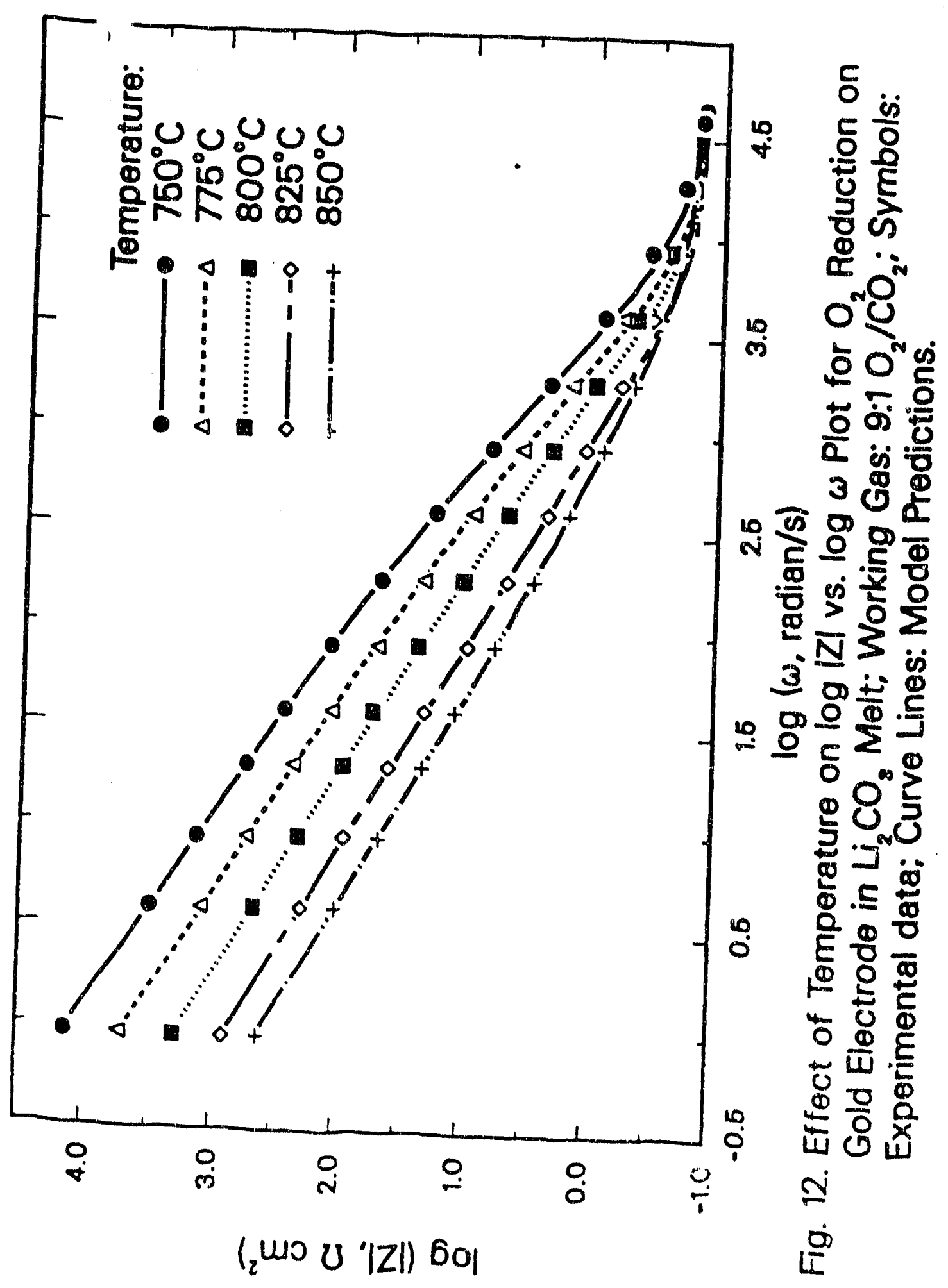


The Arrhenius plot for the exchange current density is shown in Fig. 13, and the activation energy was estimated to be $121.7 \mathrm{~kJ} \mathrm{~mol}^{-1}$. The apparent activation energy for the mass transfer parameter, $\mathrm{D}_{\mathrm{O}}^{1 / 2} \mathrm{C}_{\mathrm{O}}$, was calculated to be about $18 \mathrm{~kJ}$ $\mathrm{mol}^{-1}$ from the Arrhenius plot for it is shown in Fig. 14. The apparent activation energy for the mass transfer parameter is a sum of the activation energy for the formation of peroxide ions (Eqn. [1]) and one half of the activation energy of its diffusion coefficient. The estimated activation energy value for $D_{O}^{1 / 2} C_{O}$ is very close to that determined by Appleby and Nicholson (46) for oxygen reduction in lithium carbonate melt. Uchida et al. (61) examined the effect of temperature on oxygen reduction on a submerged gold electrode in $(\mathrm{Li}-\mathrm{K}) \mathrm{CO}_{3}$ and observed a remarkable change in these activation energies with temperature. This change in activation energy with temperature, indicates a shift in the rate controlling mechanism of oxygen reduction. The activation energies determined by Uchida et al. (63), in the region of temperature higher than $700^{\circ} \mathrm{C}$, were about 110 and $149 \mathrm{~kJ} / \mathrm{mol}$ for $i_{0}$ and $\mathrm{D}_{\mathrm{O}}^{1 / 2} \mathrm{C}_{\mathrm{O}}$, respectively. These values are close to the values obtained in this work for oxygen reduction in lithium carbonate melt, which is known to proceed via a peroxide mechanism. Also, the study conducted by Uchida et al. showed that the activation energies increased with temperature, indicating that the rate controlling mechanism has shifted to an alternate or parailel path. If the rate controlling mechanism had shifted from one of a succession of elemen ry steps to another in the series. ther the activation energy for $i_{0}$ would decrease with the increase in temperature (96). These results indicated that the oxygen reduction in $(\mathrm{Li}-\mathrm{K}) \mathrm{CO}_{3}$ eutectic melt at temperatures higher than $700^{\circ} \mathrm{C}$ proceeded via peroxide mechanism. The other rate controlling mechanism. for temperatures below $700^{\circ} \mathrm{C}$. could be the superoxide mechanism.

\section{Cyclic Voltammetry}

Cyclic voltarnmetry was carried out to study the effect of vemperature on creget. reduction on a submerged gold electrode in lithium carbonate mell for the ga- com: position of $90 \%$ ( ) and $10 \% \mathrm{CO}_{2}$. The effect of temperat ure on cyclic volummorais. 


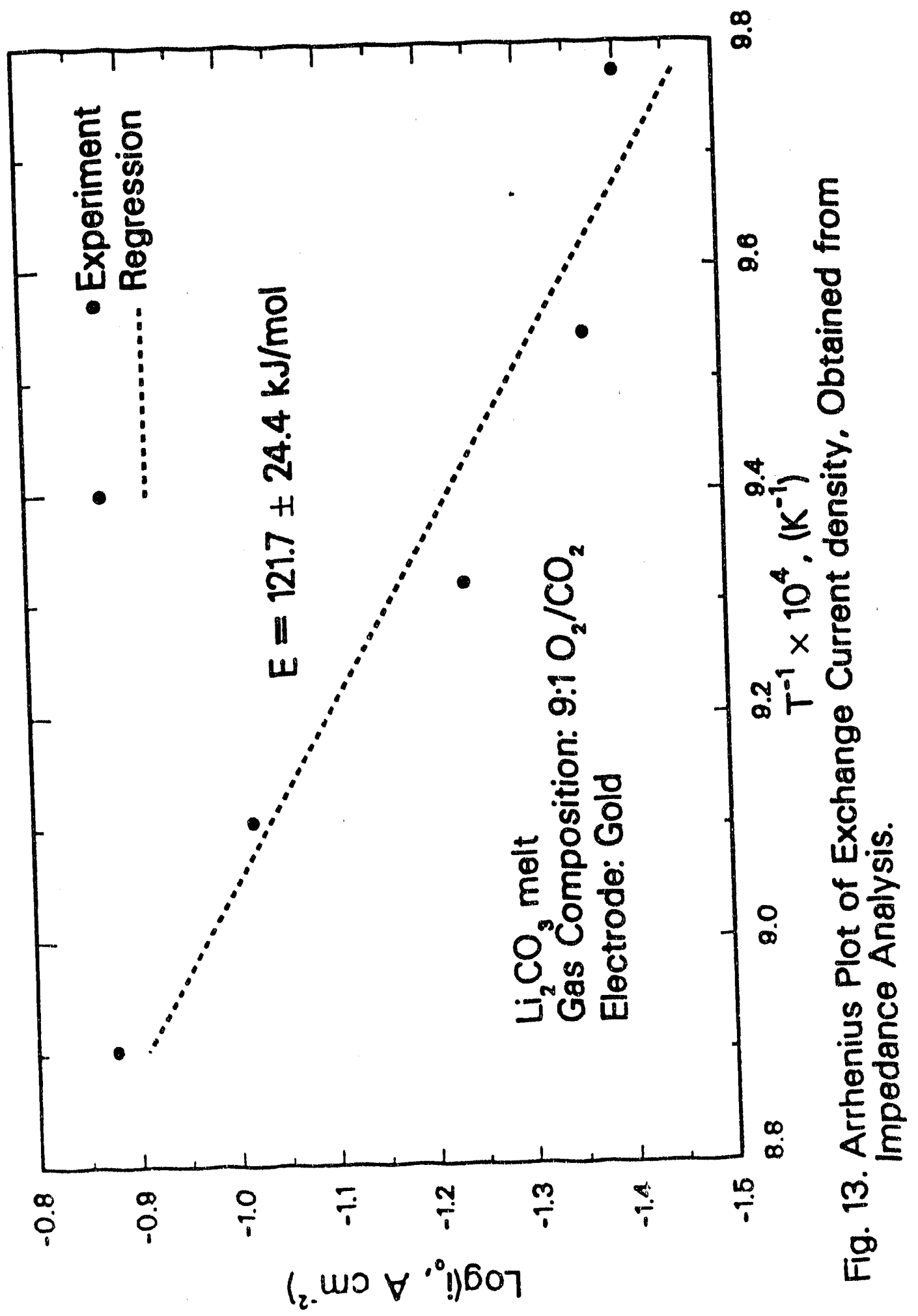




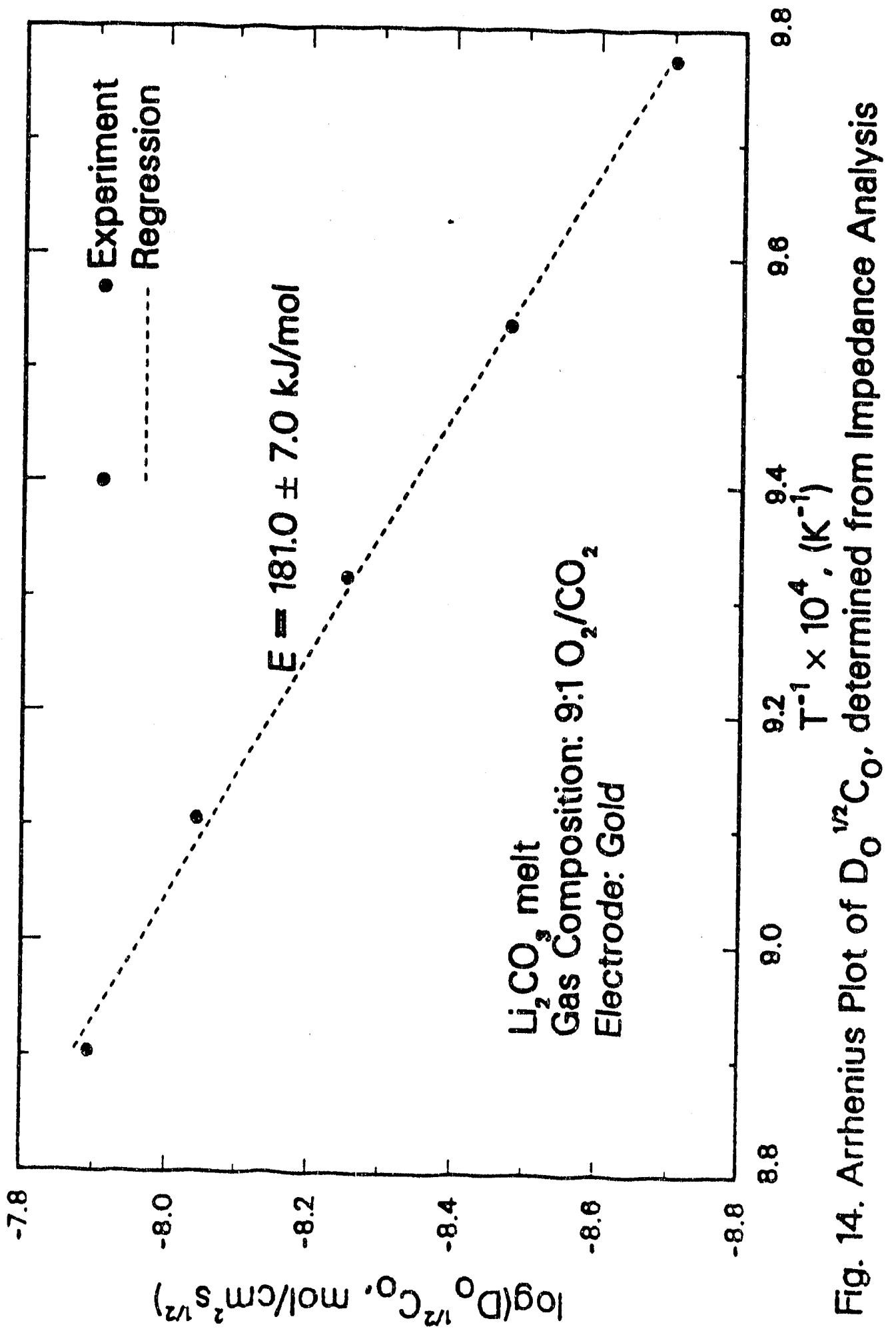


for the scan rate of $100 \mathrm{mV} / \mathrm{s}$ is shown in Fig. 15. As shown in Fig. 15, an increase in temperature increased the cathodic peak current density. The current densities in the reverse scan were less cathodic than those obtained in the forward scan and there was no peak reversal. When the applied potential returned to the initial potential, a large anodic current was observed which subsided slowly and reached zero in a few minutes. Since the cyclic voltammograms shown in Fig. 15 are for the same scan rate of $100 \mathrm{mV} / \mathrm{s}$, the area under the cathodic sweep represents the charge passed during the forward sweep. A plot of the anodic current density, observed at the end of the sweep, vs. the charge passed in the forward sweep showed a linear behavior with a slope of about 0.5 , when the potential scan rate was kept constant at $100 \mathrm{mV} / \mathrm{s}$ and temperature was varied from $750^{\circ} \mathrm{C}$ to $850^{\circ} \mathrm{C}$. Lu (23) made a similar observation for oxygen reduction on gold in a eutectic mixture of lithium carbonate and potassium carbonate. He attributed this behavior to the local accumulation of unneutralized oxide ions which shifts the reversible electrode potential in the negative direction. As suggested by Borucka. (42), the reversible electrode $\left(\mathrm{O}_{2}, \mathrm{CO}_{2} / \mathrm{CO}_{3}^{2-}\right)$ potential may depend on the local activity of oxide ion at the electrode-electrolyte interface:

$$
\mathrm{E}_{\mathrm{O}_{2}, \mathrm{CO}_{2} / \mathrm{CO}_{3}^{2-}}=\mathrm{E}_{\mathrm{O}_{2} / \mathrm{O}^{2-}}^{\circ}+\frac{\mathrm{RT}}{2 \mathrm{~F}} \ln \left(\frac{\mathrm{P}_{\mathrm{O}_{2}}^{1 / 2}}{\mathrm{a}_{\mathrm{O}^{2-}}}\right)
$$

where

$$
\mathrm{E}_{\mathrm{O}_{2} / \mathrm{O}^{2-}}^{\circ}=\mathrm{E}_{\mathrm{O}_{2}, \mathrm{CO}_{2} / \mathrm{CO}_{3}^{2-}}^{\circ}+\frac{\mathrm{RT}}{2 \mathrm{~F}} \ln \mathrm{K}_{\mathrm{d}}
$$

Lu and Selman (97) showed that oxygen electrode potential shifts in the negative direction by the addition of lithium oxide to the melt. As shown in Fig. 15, the peak potential was about $45.50 \mathrm{~m} \backslash$ negative to the reversible potential. which corresponded to $R T / n F \quad$ in $=$ ? $f($ : peroxide reductionl. The peak current density us. square root of the scan rate plots for various temperatures are shown in Fig. 16. The linear behavior of $i_{p}$, $1.1 / 2$ plots. shown in Fig. 16 . and invariance of $E_{p}$, with respect the scan rate (up to $200 \mathrm{mV} / \mathrm{s}$ ) indicates that oxygen reduction in lithium carbonate melt $i$ as fast hinetics (79). Similar behavior was observed by Lu $(23)$ and lichida et al. 11 in the eutectic mixture of lithium carbonate and potassium carbonalce. The slope 


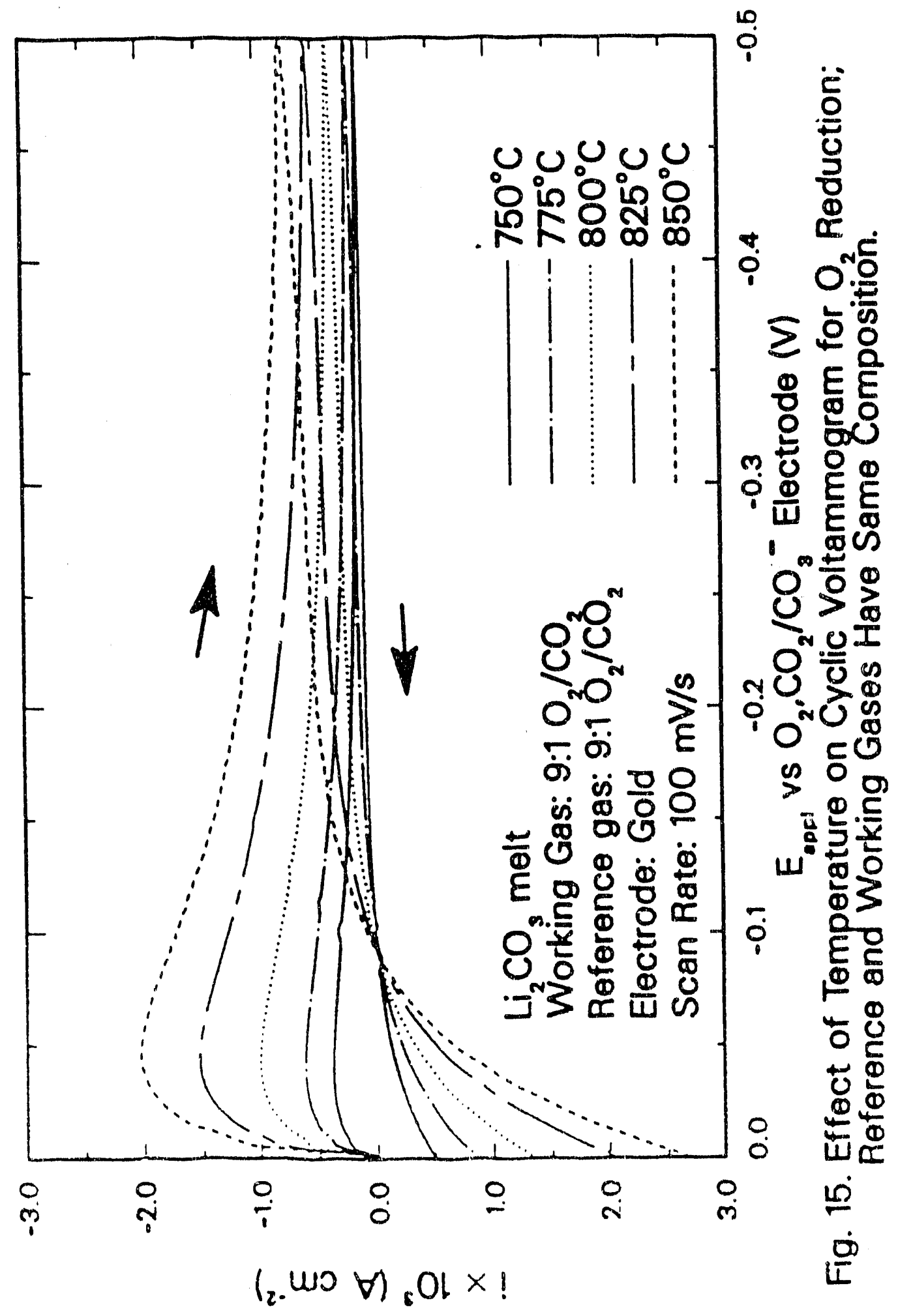


of ip vs. $1^{1 / 2}$ plot is proportional to the concentration of the diffusing species. As suggested by Appleby and Nicholson (2), the diffusion-limited peak for $\mathrm{O}_{2}$ reduction in $\mathrm{Li}_{2} \mathrm{CO}_{3}$ can be described by the theory developed by Berzins and Delahay (76) for the reversible diffusion controlled peak where the product activity is considered to be invariant and equal to unity (e.g., metal deposition) because the final product of the oxygen reduction in molten carbonate. is the carbonate ion (Eqn. [25]). The expression for the peak current density is similar to the one for the polarographic case, except the numerical coefficient is different. The proportionality between the peak current density and the concentration of the diffusing species is given below:

$$
i_{p}=0.61(\mathrm{nF} / \mathrm{RT})^{1 / 2} \mathrm{nFD}_{\mathrm{O}}^{1 / 2} \mathrm{Cov}^{1 / 2}
$$

The mass transfer parameter. $D_{O}^{1 / 2} C_{O}$, was calculated from the slope of $i_{p} v s . v^{1 / 2}$ plot by using Eqn. [84]. As shown in Table 5, the values of $\mathrm{D}_{\mathrm{O}}^{1 / 2} \mathrm{C}_{\mathrm{O}}$ obtained by cyclic voltammetry concurred well with those estimated by the electrochemical impedance spectroscopy: The product, $\mathrm{D}_{\mathrm{O}}^{1 / 2} \mathrm{C}_{\mathrm{O}}$. increased with the increase in temperature which is partly due to the increase in peroxide ion concentration. The apparent activation energy for $D_{O}^{1 / 2} C_{O}$ obtained by cyclic voltammetry was about $170 \mathrm{~kJ} /$ mole, which is consistent with the value obtained by electrochemical impedance spectroscopy:

\section{Conclusions}

The oxiges: reduchou reacti in on a submerged gold electrode in a pure lithium ca:bonate mel: was examned by electrochemical impedance spectroscopy and cyclic voliammetr lechnigues. The impedance spectro were analyzed hy the complex

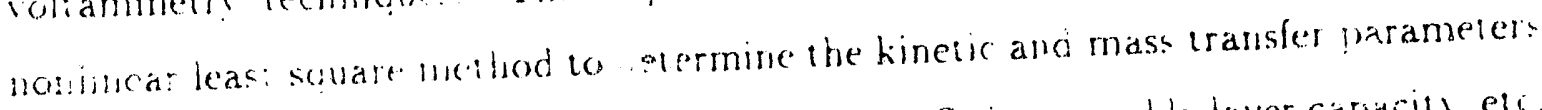

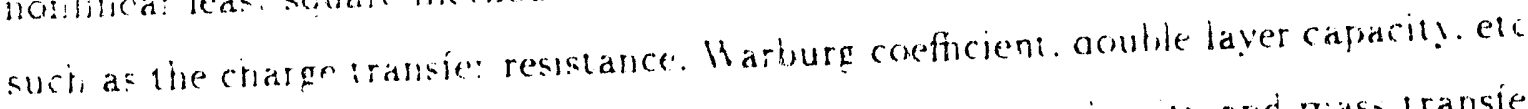

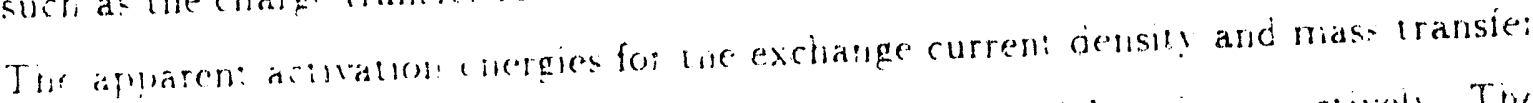

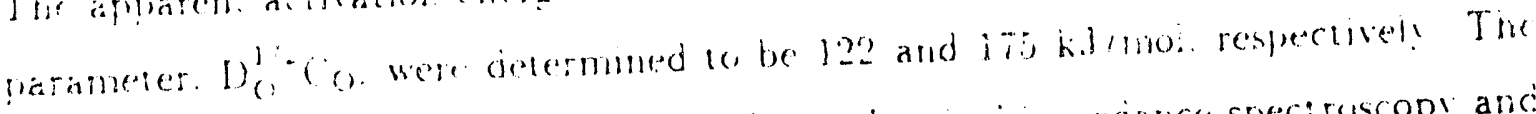

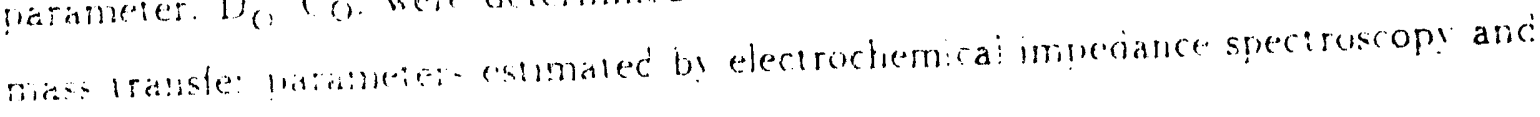

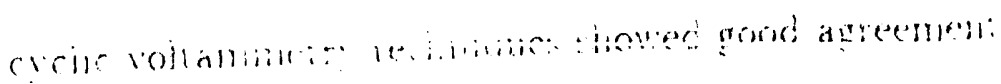




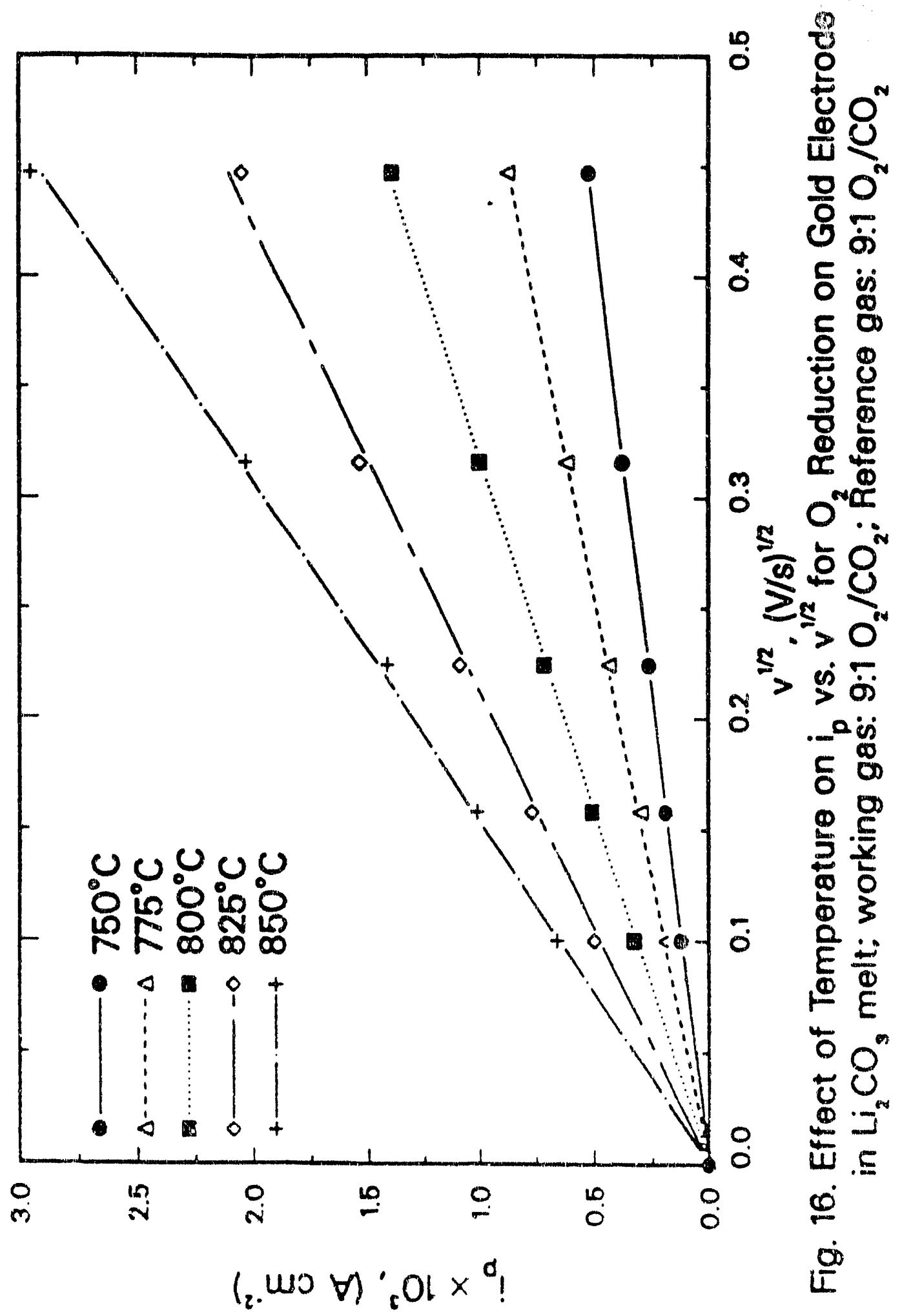


Table 5. Comparison of Product, $\mathrm{D}_{\mathrm{O}}^{1 / 2} \mathrm{C}_{\mathrm{o}}$, Estimated by Cyclic Voltammetry and Impedance Analysis; Gas Composition: $90 \% \mathrm{O}_{2}$ and $10 \% \mathrm{CO}_{2}$.

\begin{tabular}{|c|c|c|}
\hline $\begin{array}{c}\text { Temperature } \\
{ }^{\circ} \mathrm{C}\end{array}$ & \multicolumn{2}{|c|}{$\begin{array}{c}\mathrm{D}_{\mathrm{O}}^{1 / 2} \mathrm{CoX}_{\mathrm{O}} \mathrm{O}^{9} \\
\text { molcm }^{-2} \mathrm{~s}^{-1 / 2}\end{array}$} \\
\hline & Cyclic Voltammetry & Impedance Analysis \\
\hline 750 & 2.09 & $1.99 \pm 0.03$ \\
775 & 3.50 & $3.33 \pm 0.06$ \\
800 & 5.73 & $5.53 \pm 0.09$ \\
825 & 8.70 & $9.01 \pm 0.13$ \\
850 & 12.14 & $12.70 \pm 0.14$ \\
\hline
\end{tabular}




\section{CHAPTER V}

\section{EFFECTS OF PARTIAL PRESSURE OF OXYGEN}

\section{Introduction}

An elucidation of the oxygen reduction reaction in molten alkali carbonate is essential because overpotential losses in the molten carbonate fuel cell are considerably greater at the oxygen cathode than at the hydrogen anode. Appleby and Nicholson (46) examined the oxygen reduction reaction in molten carbonates on a subrnerged gold electrode, using steady state and potential scan techniques. They observed that oxygen dissolves chemically in molten carbonate as peroxide or superoxide ions depending on the cations present in the melt. In pure $\mathrm{Li}_{2} \mathrm{CO}_{3}$ and Li-rich melts, the peroxide species is dominant, whereas in a K-rich melts the superoxide species is dominant. Hence, the oxygen reduction mechanism strongly depends on the cations present in the melt. Lu (23) investigated the oxygen reduction process in pure $\mathrm{Li}_{2} \mathrm{CO}_{3}$ and in a $\mathrm{Li}-\mathrm{K}(62 \mathrm{~mol} \%: 38 \mathrm{~mol} \%)$ carbonate eutectic mixture using the potential step method. The exchange current density, determined by $\mathrm{Lu}\left(39 \mathrm{~mA} / \mathrm{cm}^{2}\right.$ for $90 \% \mathrm{O}_{2}$ and $10 \% \mathrm{CO}_{2}$ at $750^{\circ} \mathrm{C}$ in $\mathrm{Li}_{2} \mathrm{CO}_{3}$ melt), is two orders of magnitude higher than that observed b Appleby and Nicholson $\left(0.34 \mathrm{~mA} / \mathrm{cm}^{2}\right)$, who used the potential scan technique. Lu concluded that the exchange current densities. determined from the potential scan data underestimate the actual values. Lichida et al. (61. 63) determined the kinetic parameters of oxygen reduction in a Li. Fi (42.7 mol\%:57.3 mol\%) carbonate eutectic melt on a gold electrode using impedance analysis, potential step and coulostatic relaxation methods. They found that ine exchange current density was about the same order of magnitude as that observed by Lu. In addition. they concluded that impedance analysis is the most reliabie of tiv. three methods for the determination of the kinetic parameters for oxygen reduction. in molien carbonates. These studies make it clear that the mechanism of the oxige: reduction in molen carbonate is not well understord. Consequenty in the prenti: 
work, the kinetic and transport parameters are determined as a function of $\mathrm{PO}_{2}$ and temperature using cyclic voltammetry and impedance analysis.

\section{Experimental}

The experimental arrangement and the electrochemical cell assembly used in this work have been described in Chapter III. The working electrode was made of a submerged gold flag ( $0.025 \mathrm{~mm}$ thick), with a geometrical area of one square centimeter, connected to the gold current collector ( $0.5 \mathrm{~mm}$ diameter) by a thin gold wire to minimize the meniscus effect (72). The counter electrode consisted of a large gold foil, which was used as an inner liner of the cell to ensure uniform current distribution. The reference electrode was also made of a gold foil, but encased in an alumina tube which was pressed against the bottom of the electrochemical cell. The high purity $(99.9 \%)$ gold foils and wires were obtained from Johnson Matthey/ESAR Group. Digital mass fiow controllers/meters manufactured by Teledyne-Hastings Raydist were used to provide the gas mixtures of the desired compositions $\left(\mathrm{O}_{2}, \mathrm{CO}_{2}\right.$ and $\left.\mathrm{Ar}\right)$ with high precision ( $\pm 1 \%$ full scale). The high purity gases were obtained from Matheson Gas Products and the traces of water were removed by passing the blended gas through a column of $5 \AA$ molecular sieves and Drierite (Fisher Scientific). The gas mixture was bubbled into the melt in the vicinity of the working electrode at a flow rate of $50 \mathrm{~cm}^{3} \mathrm{~min}^{-1}$ by a long alumina tube with four holes. The composition of the gas mixture supplied $t 0$ the reference electrode compartment was the same as the onf

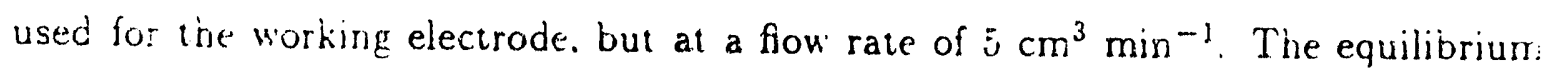
betweer the gas and the carbonate melt was achieved by bubbling the gas for at leasi 12 hours prior to the experiment. For this study. Po: was varied from 0.1 to 0.8 at $\mathrm{m}$.. while PCO, was kept constant at 0.2 atm. The total pressure was hept consioni ai I atm. by varying the partial pressure of argon. The Puratronic grade $199.999 \%$. litiium carbonate (Alfa Products) was carefully weighed in an alumina crucible ( $9(1$ nit capacing, and the electrochemical cell was slowly heated $\left(50^{\circ} \mathrm{C} / \mathrm{hr}\right)$ i. $350^{\circ} \mathrm{C}$ un!

oc: incri envirumeni. The electrochemical cell assembly was dried at $350{ }^{\circ} \mathrm{C}$ in . 
carbon dioxide environment for 24 hours before heating to $800^{\circ} \mathrm{C}$. The data acquisition set-up consisted of a potentiostat/galvanostat (Model 273), lock-in-amplifier (Model 5301A), personal cothputer (IBM PS/2), and software (Model 378) supplied by EG\&G PAR.

\section{Cyclic Voltammetry}

Cyclic voltammetry measurements were made for oxygen reduction on a gold electrode in a quiescent $\mathrm{Li}_{2} \mathrm{CO}_{3}$ melt as a function of scan rate, temperature, and $\mathrm{P}_{\mathrm{O}_{2}}$. The working electrode potential was scanned between the rest potential and $-0.5 \mathrm{~V}$ vs. reference electrode; the scan rate was varied from 10 to $200 \mathrm{mV} / \mathrm{s}$. The effect of $\mathrm{PO}_{2}$ on the cyclic voltammogram, recorded at the scan rate of $100 \mathrm{mV} / \mathrm{s}$ at $800^{\circ} \mathrm{C}$ temperature is shown in Fig.17. During the forward scan, a diffusion-limited peak, followed by a limiting plateau, was observed. The peak potential $\left(E_{p}\right)$ was found to be independent of the scan rate (up to $200 \mathrm{mV} / \mathrm{s}$ ) and the position of this peak was 40-45 $\mathrm{mV}$ negative to the rest potential. Appleby and Nicholson (46) made a similar observation and attributed it to peroxide reduction in a $\mathrm{Li}_{2} \mathrm{CO}_{3}$ melt, as shown in the following mechanism:

$$
\begin{aligned}
1 / 2 \mathrm{O}_{2}+\mathrm{CO}_{3}^{2-} & =\mathrm{O}_{1}^{2-}+\mathrm{CO}_{2} \\
\mathrm{O}_{2}^{2-}+\mathrm{e}^{-} & =\left(\mathrm{O}^{-}\right)+\mathrm{O}^{2-} \\
\left(\mathrm{O}^{-}\right)+\mathrm{CO}_{2}+\mathrm{e}^{-} & =\mathrm{CO}_{3}^{2-} \\
\mathrm{O}^{2-}+\mathrm{CO}_{2} & =\mathrm{CO}_{3}^{2-}
\end{aligned}
$$

The overali reaction is

$$
1 / 2 \mathrm{O}_{2}+\mathrm{CO}_{2}+2 \mathrm{e}^{-}=\mathrm{COO}_{3}^{--}
$$

where $\left(\mathrm{O}^{-} \mathrm{l}\right.$ is a trarsient species. In this study. it was concluded that the first charge transfer reaction (Eqn. [S6] is the rate determining step for an immersed electrode. The current densities in the reverse scan were fowe: than those in the forward scall 


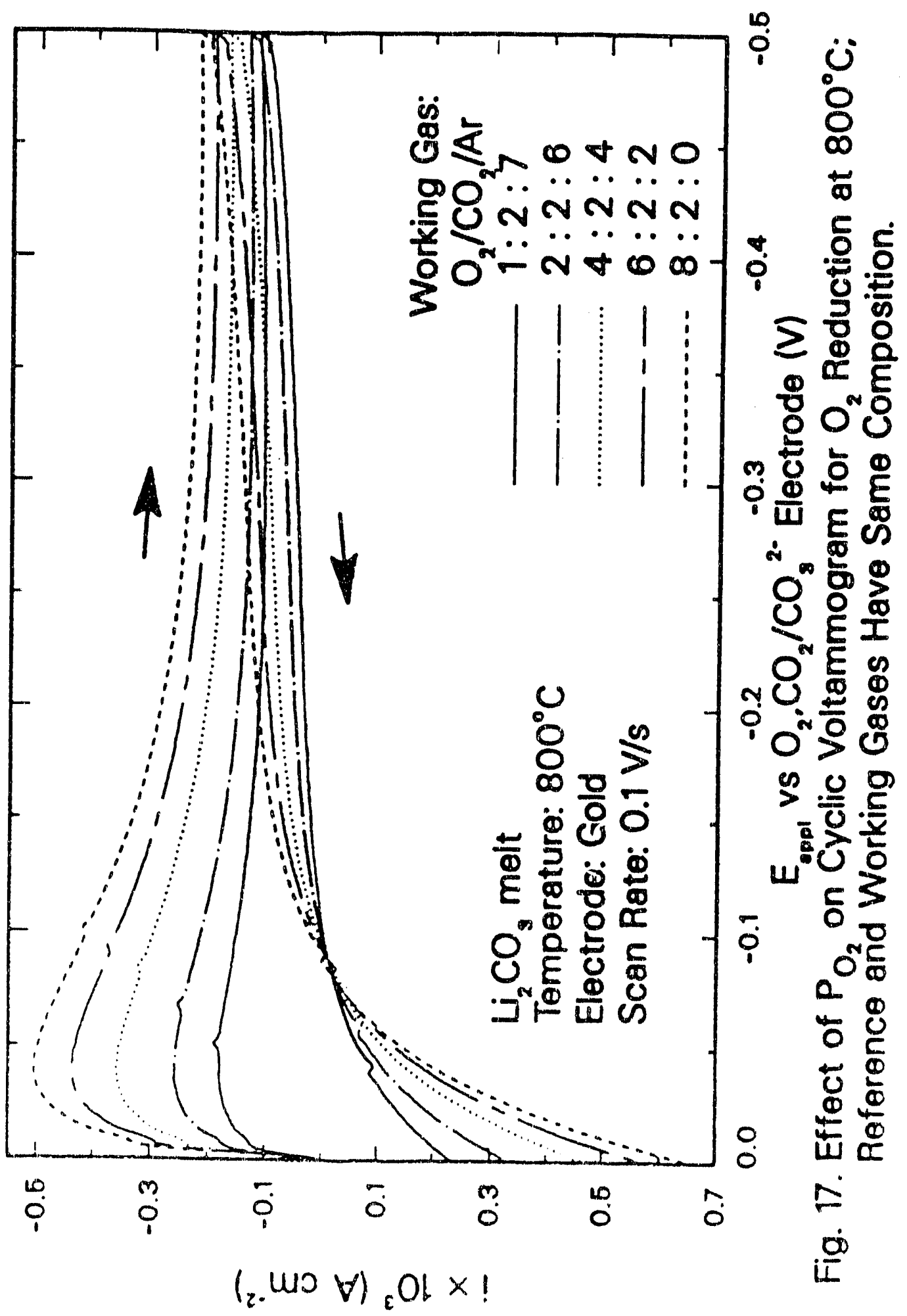


and at the end of the cycle, large anodic current densities, which subsided slowly and reached zero in a few minutes, were observed. Lu (23) observed similar behavior for $\mathrm{O}_{2}$ reduction in $\mathrm{Li}-\mathrm{K}$ melt and attributed it to an increase in the basicity of the melt near the working electrode due to an accumulation of oxide ions produced during the forward sweep, which shifts the equilibrium potential in the negative direction.

A plot of the effect of $\mathrm{P}_{\mathrm{O}_{2}}$ on the peak current density $\left(\mathrm{i}_{\mathrm{p}}\right)$ vs. square root of the scan rate $\left(v^{1 / 2}\right)$ at $800^{\circ} \mathrm{C}$ is shown in Fig. 18. The linear behavior of $i_{p} v s . v^{1 / 2}$, shown in Fig. 18, and the invariance of $E_{p}$ with respect to the scan rate (Fig. 17) indicate that oxygen reduction in a $\mathrm{Li}_{2} \mathrm{CO}_{3}$ melt is reversible up to $200 \mathrm{mV} / \mathrm{s}$ (79). As shown in Fig. 18, an increase in partial pressure of oxygen increases the slope of the $i_{p} v s$. $r^{1 / 2} \mathrm{plc}$ As suggested by Appleby and Nicholson (46), the diffusion-limited peak for $\mathrm{O}_{2} \mathrm{r}$ ducior in $\mathrm{Li}_{2} \mathrm{CO}_{3}$ can be described by the theory developed by Berzins and Delahay (76) for the reversible diffusion controlled peak where the product activity is considered to be invariant and equal to unity (e.g. metal deposition). According to Berzins and Delahay, the peak current density is given by the following expression:

$$
i_{p}=0.61 \frac{(n \mathbf{F})^{3 / 2}}{(R T)^{1 / 2}} C_{O} D_{O}^{1 / 2} v^{1 / 2}
$$

The transport parame er $\mathrm{D}_{\mathrm{O}}^{1 / 2} \mathrm{C}_{\mathrm{O}}$ was calculated from the slope of $\mathrm{i}_{\mathrm{p}}$ vs. $v^{1 / 2}$ plot using Eqn. [90]. The calculated values of this transport parameter for various $P_{O}$; are given in Table 6. Increase in partial pressure of oxygen increased the product $\mathrm{D}_{\mathrm{O}}^{1 / 2} \mathrm{CO}$. mainly due to increase in peroxide ion concentration. Plots of the effect of $\mathrm{PO}_{2}$ on the cyclic voltammogram and on the $i_{p}$ vs. $v^{1 / 2}$ plots at $850^{\circ} \mathrm{C}$ are shown in Figs. 19 and 20 respectively: estimated values of $\mathrm{D}_{\mathrm{O}}^{1 / 2} \mathrm{C}_{\mathrm{O}}$ are given in Table 6 . The lemperature change caused a two fold increase in $\mathrm{D}_{\mathrm{O}}^{1 / 2} \mathrm{C}_{0}$. Reaction order plots for

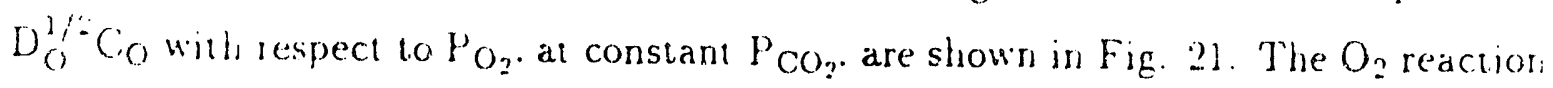
order obrained by linear regression analysis is close to +0.5. Which agreed well witi. the pesoxide formation step (Equ. [85]) in the reaction mechansm described earlie: 


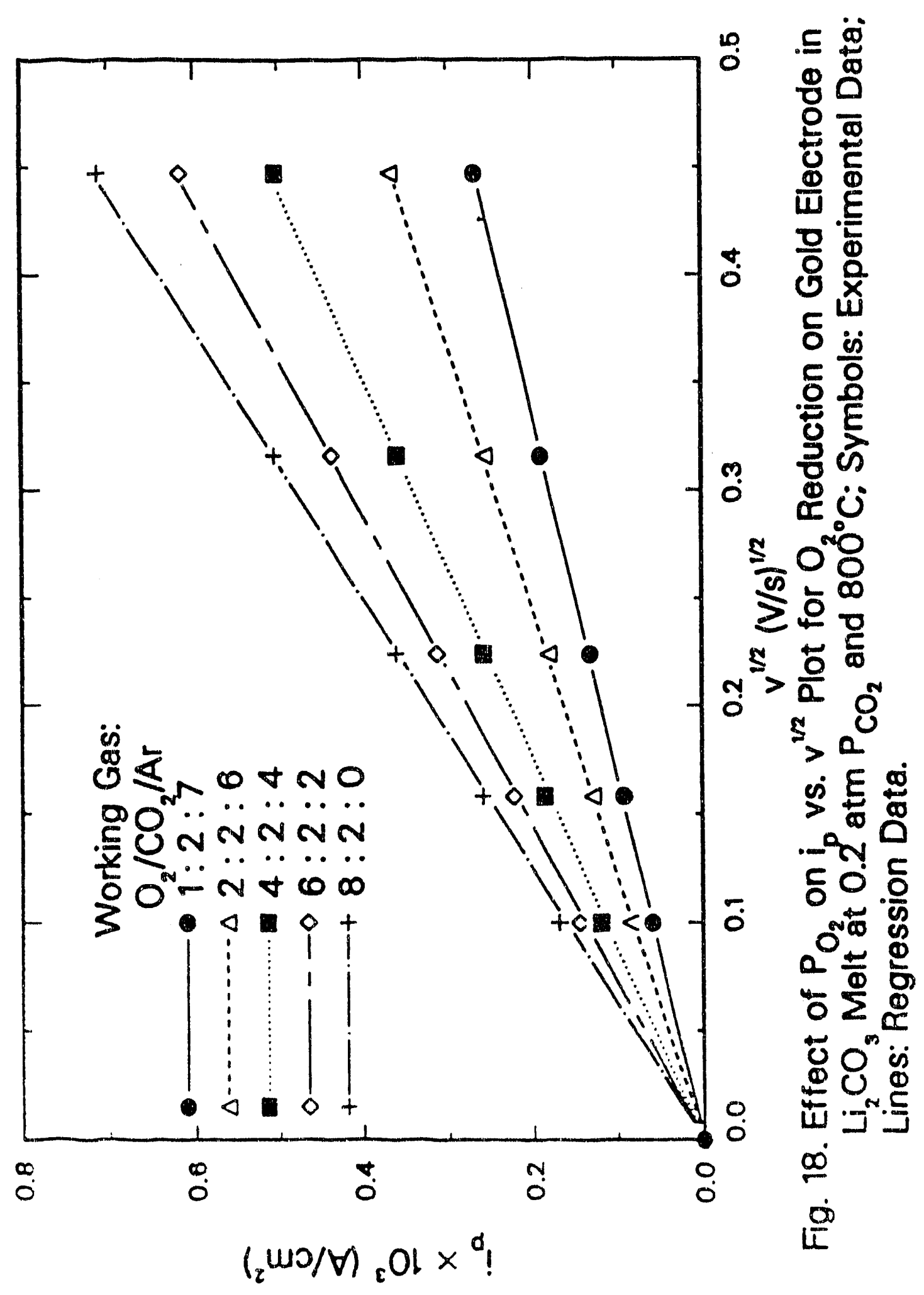




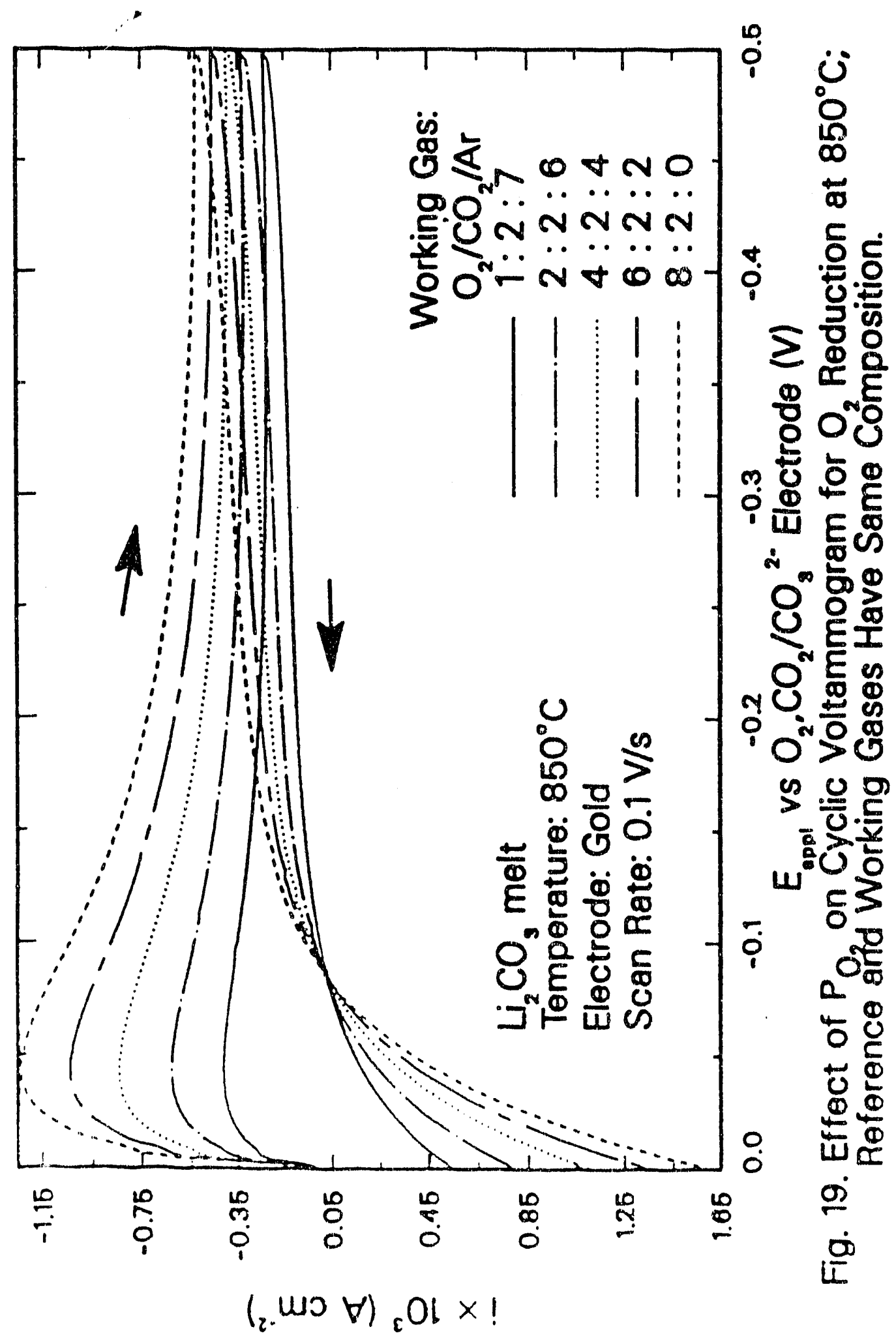




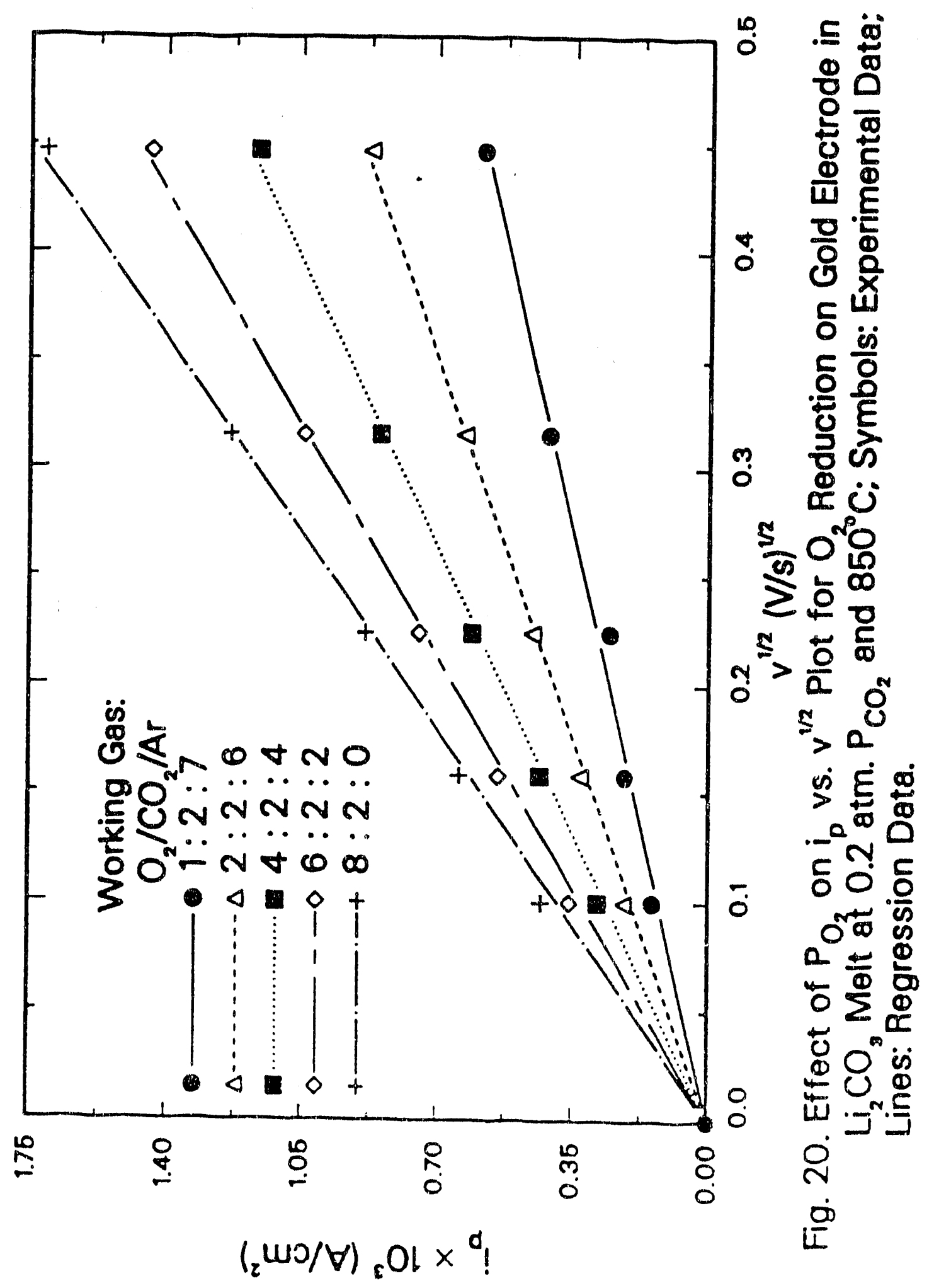


Table 6. Influence of $\mathrm{P}_{\mathrm{O}_{2}}$ on Product $\mathrm{D}_{\mathrm{O}}^{1 / 2} \mathrm{C}_{\mathrm{O}}$ Estimated by Cyclic Voltammetry and Electrochemical Impedance Spectroscopy at 0.2 atm $\mathrm{P}_{\mathrm{CO}_{2}}$.

\begin{tabular}{|c|c|c|c|c|}
\hline & \multicolumn{4}{|c|}{$\begin{array}{l}\mathrm{D}_{\mathrm{O}}^{1 / 2} \mathrm{C}_{\mathrm{O}} \times 10^{9} \\
\mathrm{~mol} \mathrm{~cm} \mathrm{~cm}^{-2} \mathrm{sec}^{-1 / 2}\end{array}$} \\
\hline $\begin{array}{l}\text { Temperature } \\
{ }^{\circ} \mathrm{C}\end{array}$ & \multicolumn{2}{|c|}{800} & \multicolumn{2}{|c|}{850} \\
\hline $\begin{array}{l}\mathrm{P}_{\mathrm{O}_{2}} \\
\text { atm }\end{array}$ & $\begin{array}{c}\text { Cyclic } \\
\text { Voltammetry }\end{array}$ & $\begin{array}{c}\text { Impedance } \\
\text { Analysis }\end{array}$ & $\begin{array}{c}\text { Cyclic } \\
\text { Voltammetry }\end{array}$ & $\begin{array}{c}\text { Impedance } \\
\text { Analysis }\end{array}$ \\
\hline 0.1 & 1.08 & $1.03 \pm 0.04$ & 2.41 & $2.53 \pm 0.06$ \\
\hline 0.2 & 1.49 & $1.49 \pm 0.03$ & 3.71 & $3.08 \pm 0.09$ \\
\hline 0.4 & 2.07 & $2.12 \pm 0.07$ & 4.95 & $5.25 \pm 0.17$ \\
\hline 0.6 & 2.53 & $2.70 \pm 0.09$ & 6.12 & $6.60 \pm 0.22$ \\
\hline 0.8 & 2.92 & $3.08 \pm 0.10$ & 7.26 & $7.65 \pm 0.28$ \\
\hline
\end{tabular}




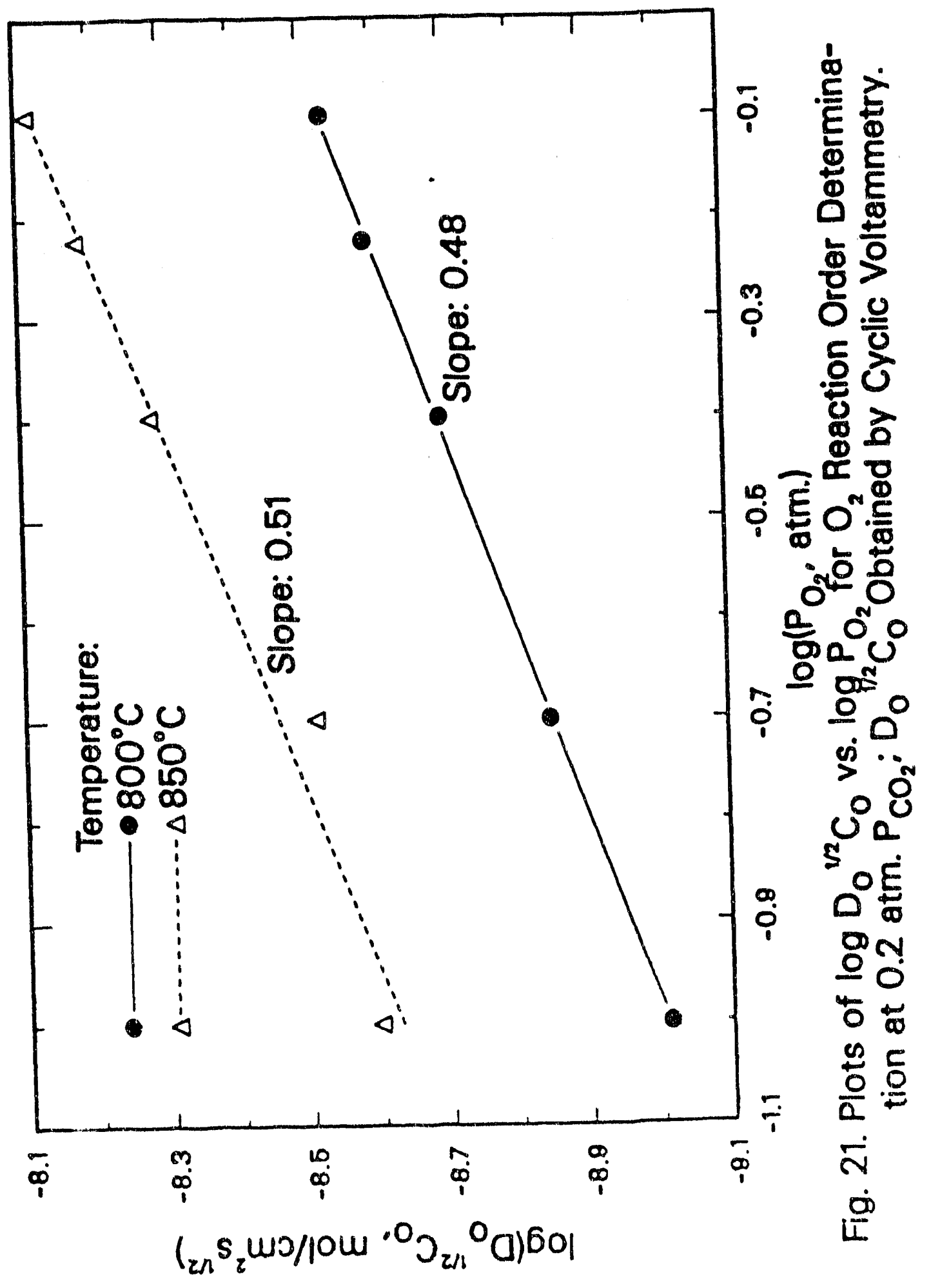




\section{Electrochemical Impedance Measurements and Analyses}

The impedance measurements were carried out for oxygen reduction in $\mathrm{Li}_{2} \mathrm{CO}_{3}$ melt at the rest potential as a function of $\mathrm{P}_{\mathrm{O}_{2}}$, temperature and frequency $(0.05 \mathrm{~Hz}-10$ $\mathrm{kHz}$ ). For frequencies higher than $10 \mathrm{kHz}$, an inductive behavior (positive imaginary impedance) was observed; hence the high frequency measurements were limited to 10 kHz. Figs. 22 and 23 show the effect of $\mathrm{P}_{\mathrm{O}_{2}}$ on the Bode plot (phase angle vs. $\log \omega$ ) for $800^{\circ} \mathrm{C}$ and $850^{\circ} \mathrm{C}$ respectively. For high frequencies, the phase angle approached $0^{\circ}$, indicating a purely resistive behavior of the impedance. The impedance at $0^{\circ}$ phase angle is a measure of the solution resistance $\left(R_{s}\right)$ between the working and reference electrodes. At low frequencies, the phase angle approached $-45^{\circ}$, indicating that mass transfer (Warburg) impedance was dominant. The effect of $\mathrm{P}_{\mathrm{O}_{2}}$ on oxygen reduction kinetics is evident at intermediate frequencies, reflecting an increase of charge transfer resistalice $\left(\mathrm{R}_{\mathrm{cl}}\right)$ with decrease in $\mathrm{P}_{\mathrm{O}_{2}}$. The effect of temperature can be observed by comparison of Figs. 22 and 23; an increase of temperature decreases the charge transfer resistance and the mass transfer resistance became dominant at relatively higher frequencies. The sharp deviations in the data near $110 \mathrm{~Hz}$ frequency are due to the measurement system.

A Complex Nonlinear Least Square (CNLS) parameter cstimation program (89. 90), based on the Randles-Ershler equivalent circuit $(83,84)$, was used for the impedance analysis. This analysis provides estimates of the charge transfer resistance $\left(\mathrm{K}_{\mathrm{cl}}\right)$. double layer capacity $\left(\mathrm{C}_{\mathrm{dl}}\right)$, Warburg coefficient $(\sigma)$, and solution resistance $\left(F_{*}\right)$. In our analysis, we found that the weighting factor (inverse of the error variance) infivenced the accuracy of the parameters estimated from the impedance data. Thus 111 this work. we used a proportional weighting factor (94) to estimate kinetic and mass transier parameters from the impedance data. Figs. 24 and 25 show the effeci of $\mathrm{P}_{\mathrm{O}}$ : on sed impedance $(Z)$ is. the inverse square root of angular frequency $\left(\omega^{-1 / 2}\right)$ for lemperatures $800^{\circ} \mathrm{C}$ and $850^{\circ} \mathrm{C}$. respectively. In a low frequency region. $Z$ is. $\omega^{-1 / 2}$ plois showed a linear behavior with a slope proportional to the Viarburg Coefficien: ic: As shown in Figs. 24 and 25.0 dreceaned with increase in $\mathrm{P}_{\mathrm{O}_{2}}$ and $t$ mmperature. 


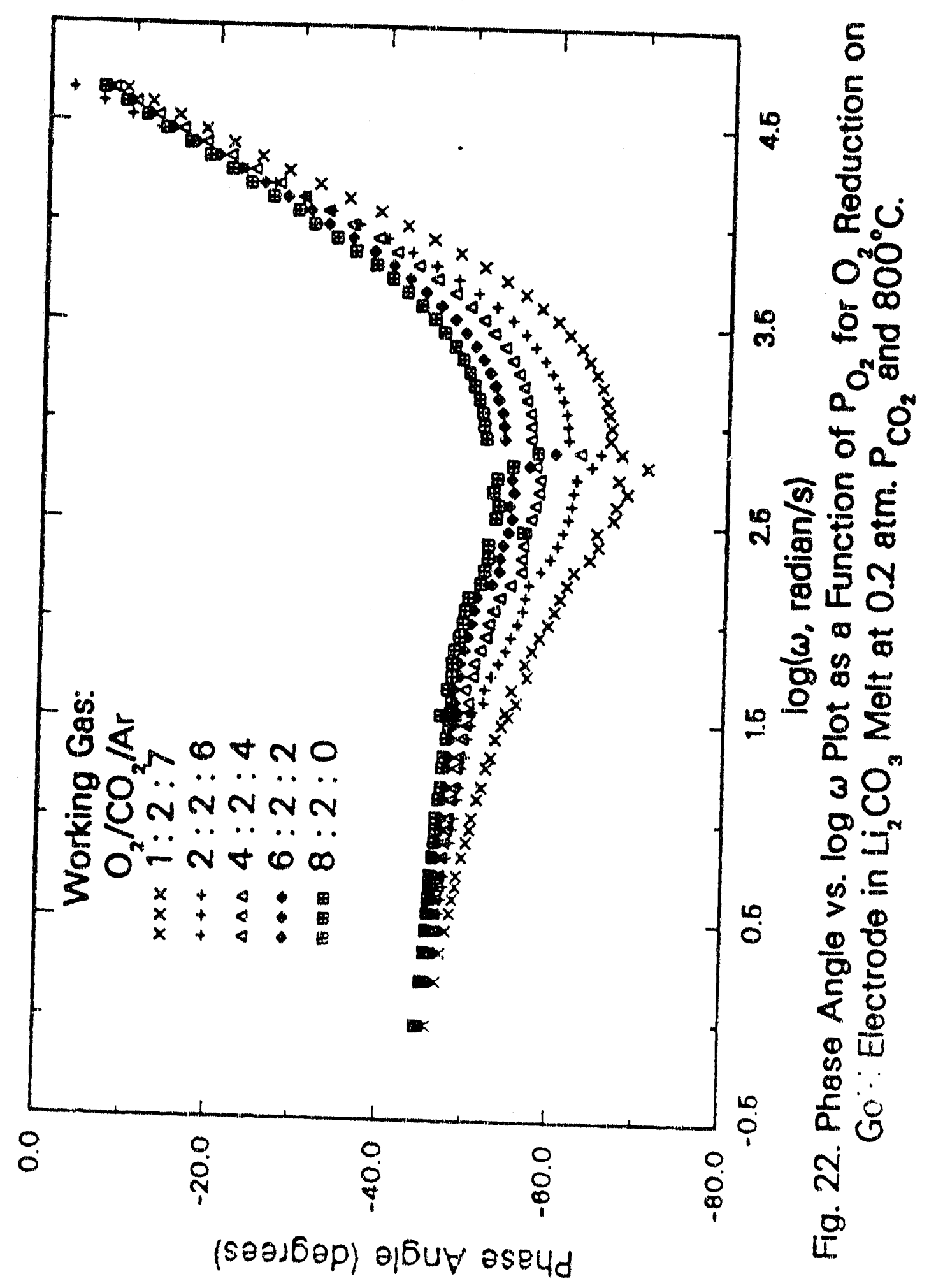




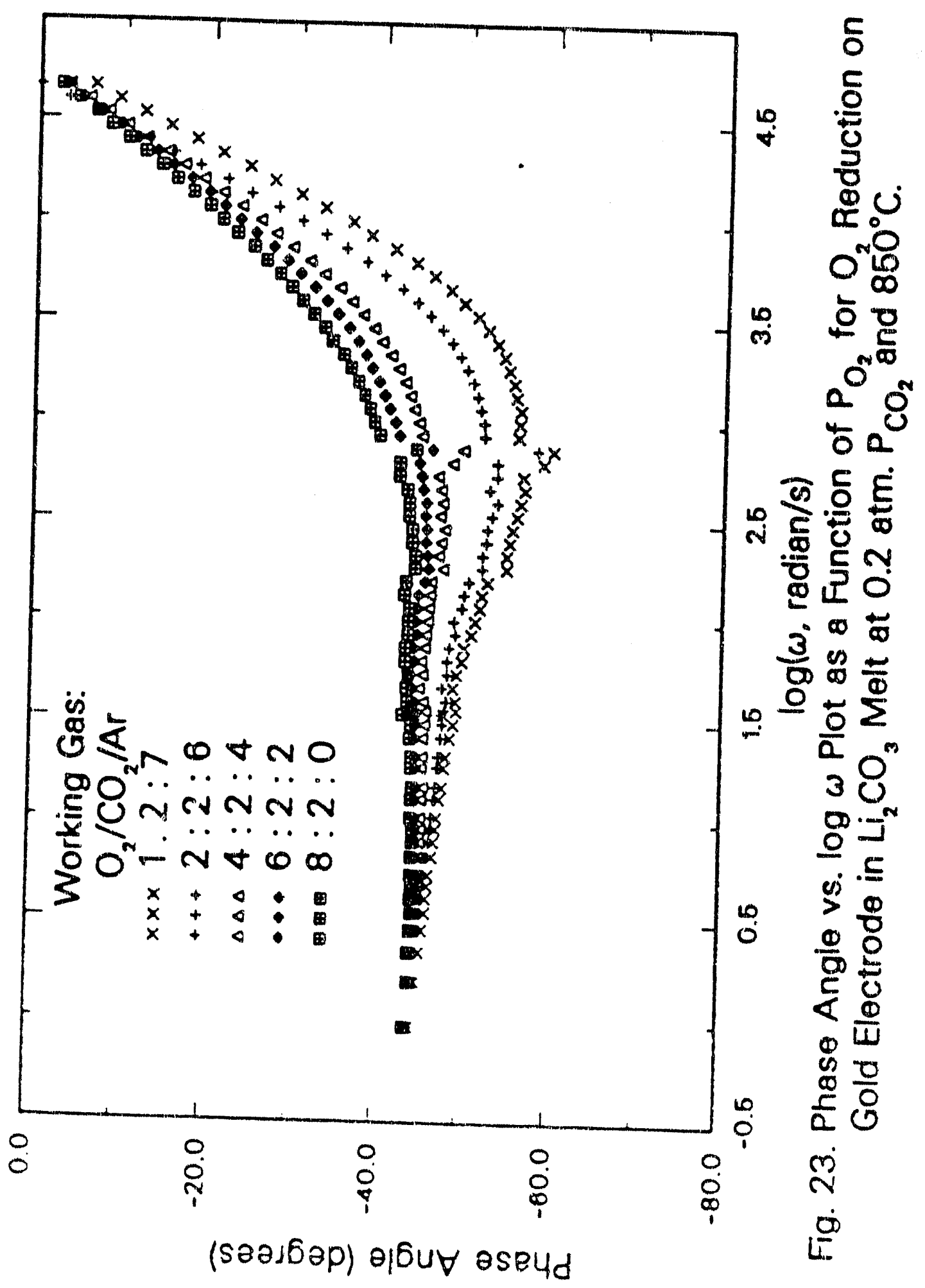


due to an increase in peroxide ion concentration. The curved lines in Figs. 24 and 25 show $Z^{n}$ vs. $w^{-1 / 2}$ plots for the data computed by the model using estimated parameters. The estimated parameters for various partial pressures of oxygen are given in Tables 7 and 8 . These tables show that increase in $\mathrm{PO}_{2}$ and temperature decreases $R_{C l}$ and $\sigma$, whereas the change in $R_{6}$ is negligible. The effects of $\mathrm{PO}_{2}$ and temperature on the impedance spectrum can be observed from $\log |Z|$ vs. $\log w$ plots shown in Figs. 26 and $2 i$.

Since impedance measurements were obtained at the rest potential, the following expressions can be used for the charge transfer resistance and the Warburg coefficient (S0):

$$
\begin{gathered}
R_{c t}=\frac{R T}{n F i_{c}} \\
\sigma=\frac{R T}{n^{2} F^{2} A \sqrt{2}}\left(\frac{1}{D_{O}^{1 / 2} C_{O}}+\frac{1}{D_{R}^{1 / 2} C_{R}}\right)
\end{gathered}
$$

For peroxide reduction in $\mathrm{Li}_{2} \mathrm{CO}_{3}$ melt, $\mathrm{CO}_{\mathrm{O}}$ is rnuch smaller than $\mathrm{C}_{\mathrm{R}}$ because the final product is carbonate jon. Therefore $1 / D_{R}^{1 / 2} C_{R}$ is negligible compared with $1 / D_{O}^{1 / 2} C_{O}$. Thus Eqn. [92] can be approximated by the following expression:

$$
\sigma=\frac{\mathrm{RT}}{\mathrm{n}^{2} \mathrm{~F}^{2} \mathrm{~A} \sqrt{2}}\left(\frac{1}{\mathrm{D}_{\mathrm{O}}^{1 / 2} \mathrm{C}_{\mathrm{O}}}\right)
$$

['sing Equ. [91] (where $n=2$, fo: peroxide reduction). exchange current densities (io) arculated for several values of $\mathrm{PO}_{0}$, and temperature. are shown in Tables $T$ and 8 . I... esmanies values of the exchange current densigy are closer to those obtained 1. 1.1. 2.3 and lichida al al. (6i) but two orders of magnitude higher than those (1) served Appleby and Nicholson (46). who used potential sweep technique. Lu wed the potential sweep and potential step techriques to study the oxygen reduc. ilon: in a Li-li (62 mol\%:38 mol\%) carbonate eutectic mixiure on a gold electrode. Iie showed that the exchange current densities determined by the potential sweep

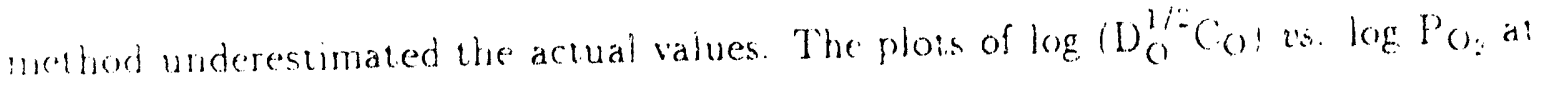
in. temperatures are shown in Fig. 28 . From the slopes of these lines. the reaction:

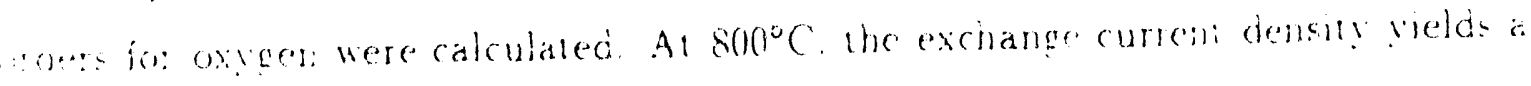




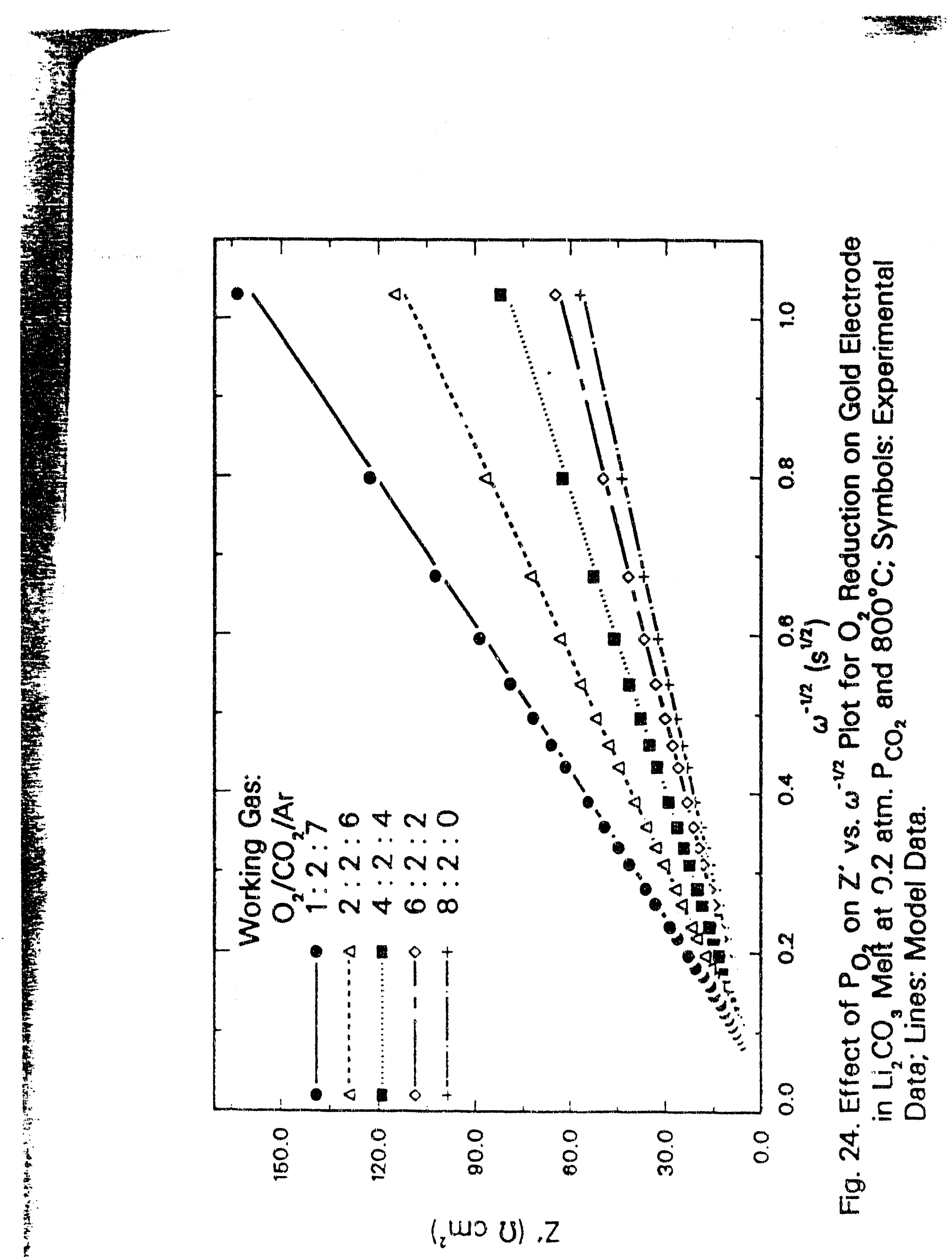




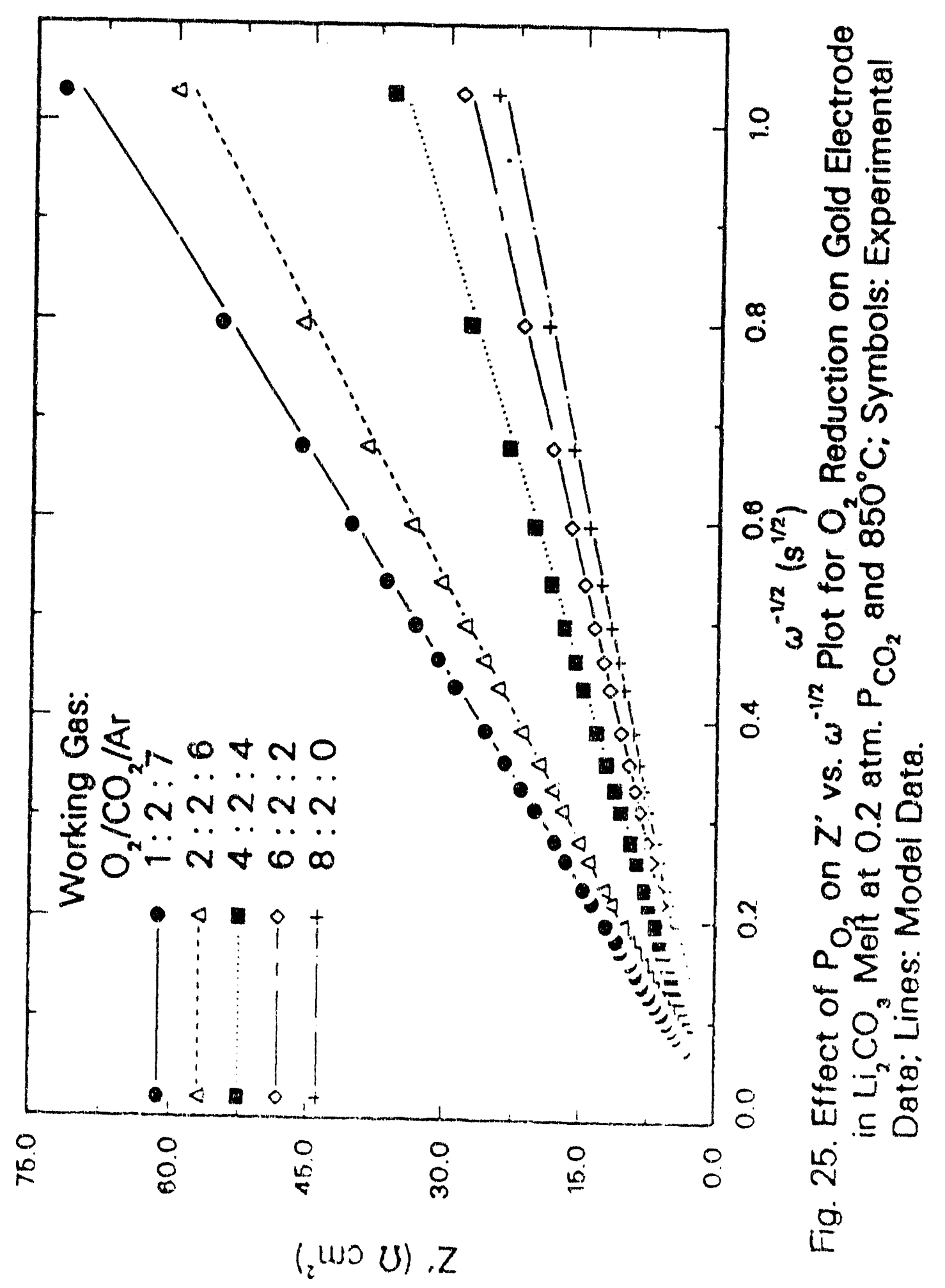


Table 7. Electrode Kinetic and Mass Transfer Parameters Estimated by Electrochemical Impedance Spectroseopy Technique at $800^{\circ} \mathrm{C}$ and 0.2 atm $\mathrm{PCO}_{2}$.

\begin{tabular}{|c|c|c|c|c|c|}
\hline $\begin{array}{c}\mathrm{PO}_{3} \\
\mathrm{~atm}\end{array}$ & $\begin{array}{c}\sigma \\
\Omega \mathrm{cm}^{2} \mathrm{~s}^{-1 / 2}\end{array}$ & $\begin{array}{c}\mathrm{R}_{\mathrm{cl}} \\
\Omega \mathrm{cm}^{2}\end{array}$ & $\begin{array}{c}\mathrm{i}_{0} \times 10^{3} \\
\mathrm{~A} \mathrm{~cm}\end{array}$ & $\begin{array}{c}\mathrm{C}_{\mathrm{dl}} \times 10^{6} \\
\mathrm{~F} \mathrm{~cm}\end{array}$ & $\begin{array}{c}\mathrm{R}_{\mathrm{s}} \\
\Omega \mathrm{cm}^{2}\end{array}$ \\
\hline 0.1 & $164.4 \pm 6.3$ & $1.79 \pm 1.47$ & $25.9 \pm 21.3$ & $270.5 \pm 14.7$ & 0.35 \\
0.2 & $114.0 \pm 2.5$ & $1.49 \pm 0.57$ & $31.1 \pm 11.9$ & $292.6 \pm 11.0$ & 0.40 \\
0.4 & $79.8 \pm 2.7$ & $1.17 \pm 0.52$ & $39.3 \pm 17.3$ & $324.3 \pm 17.5$ & 0.36 \\
0.6 & $62.8 \pm 2.1$ & $1.07 \pm 0.39$ & $43.3 \pm 15.7$ & $348.8 \pm 18.3$ & 0.37 \\
0.8 & $55.1 \pm 1.9$ & $0.95 \pm 0.34$ & $48.7 \pm 17.3$ & $366.0 \pm 20.8$ & 0.37 \\
\hline
\end{tabular}




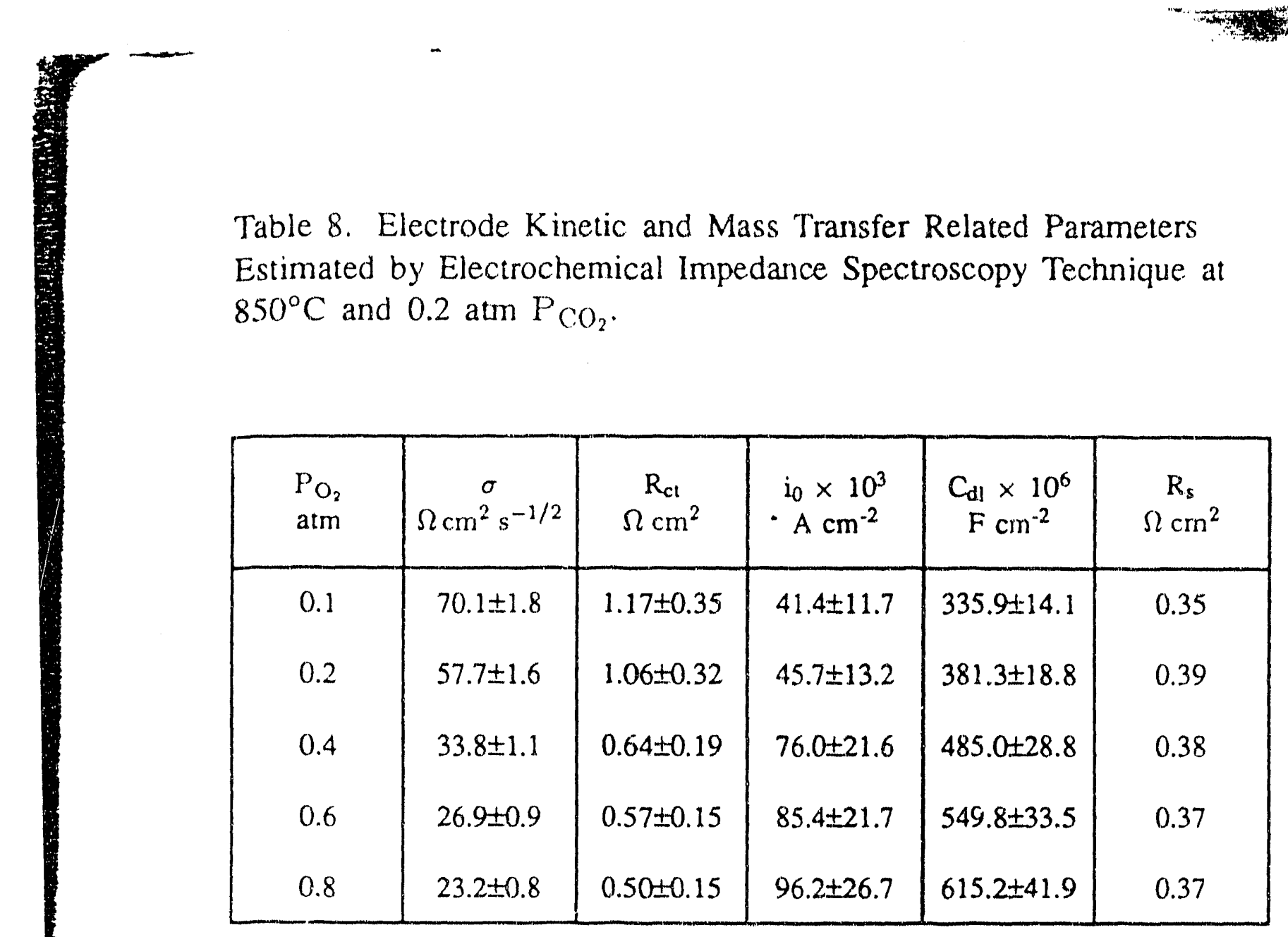




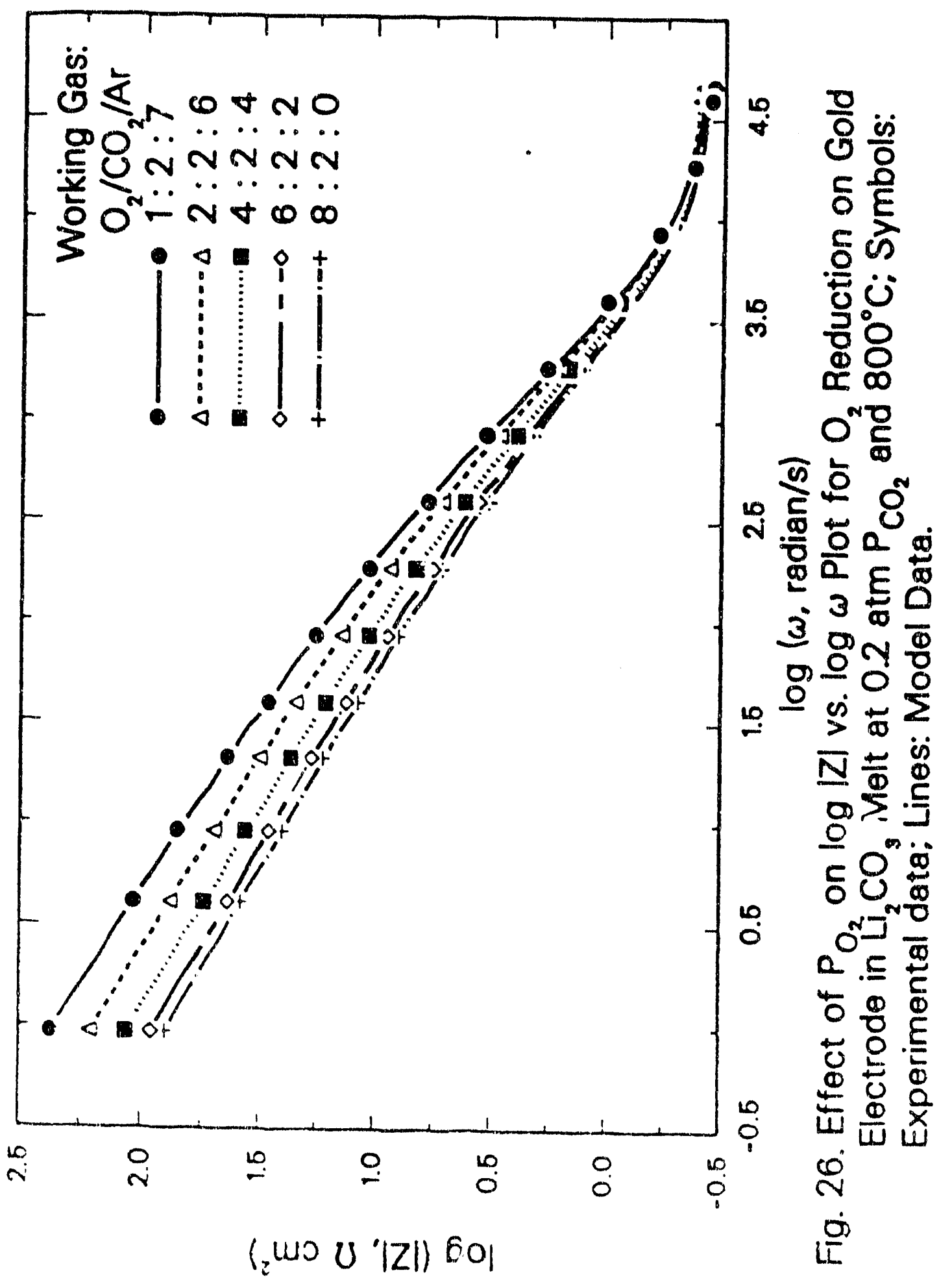




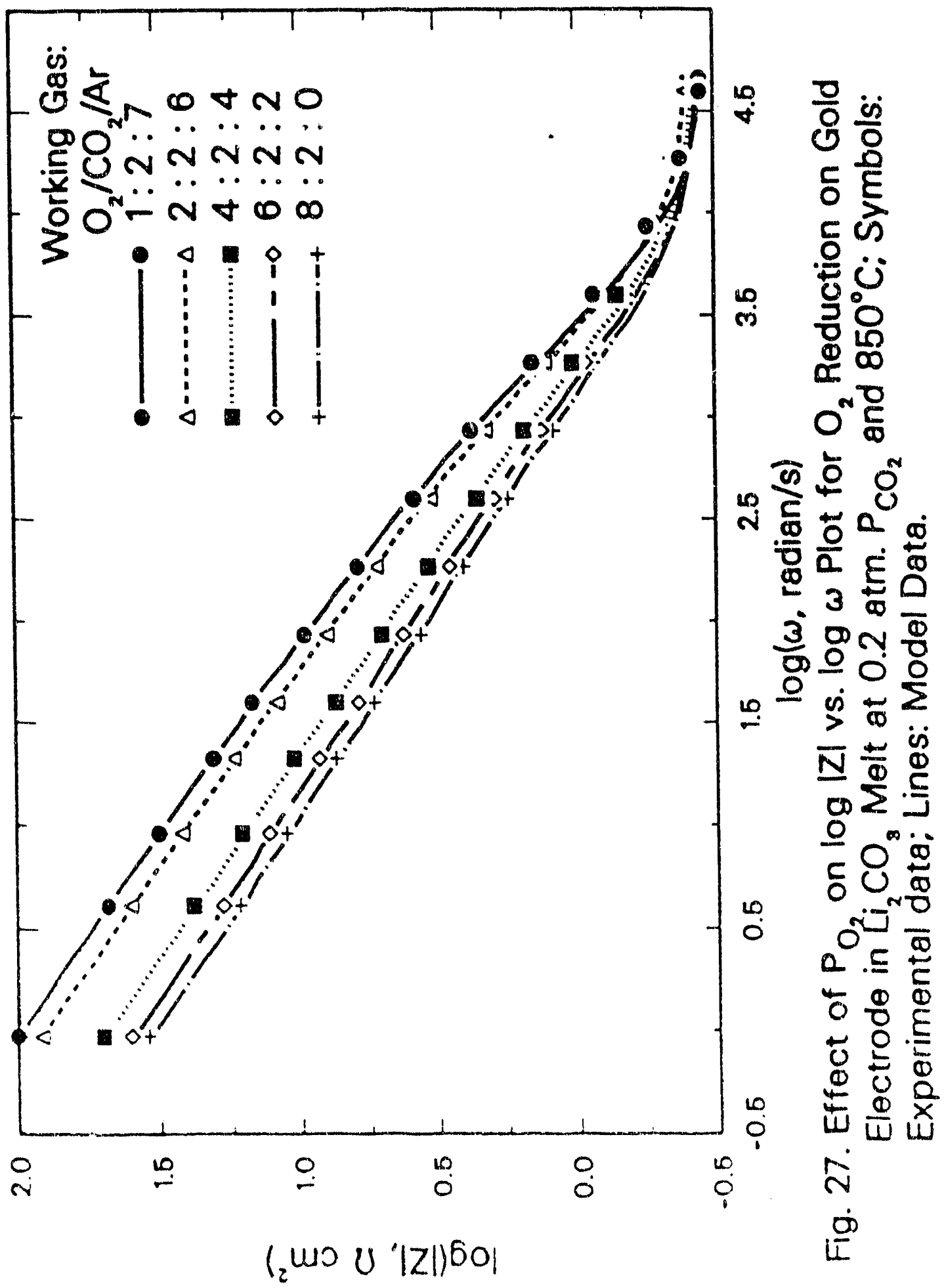


positive reaction order of walue 0.30 with respect to l'o., which is consistent with the peroxide reaction mechanisn. proposed by Appleby and Nicholson (46). when the first charge transfer (Eqn. [86]) is the rate determining step (r.d.s) and the symmetry factor $(\beta)$ has a value of 0.5 . As shown in Tables $\tau$ and $\delta$. the capacitance increases with an increase in $\mathrm{P}_{\mathrm{O}_{2}}$ and this increase is more noticeable at higher temperature. The mass transfer parameter $\mathrm{D}_{\mathrm{O}}^{1 / 2} \mathrm{C}_{\mathrm{O}}$ was calculated from the expression for the Warburg coefficient (Eqn. [93]). As shown in Table 6, the mass transfer parameters estimated by impedance analysis and cyclic voltammetry techniques are in good agreement. For comparison with the data available in literature, the concentration of peroxide $\left(\mathrm{C}_{O}\right)$ was calculated from the mass transfer parameter $\mathrm{D}_{\mathrm{O}}^{1 / 2} \mathrm{C}_{\mathrm{O}}$ for the diffusion coefficient of about $1 \times 10^{-5} \mathrm{~cm}^{2} \mathrm{~s}-1$. As shown in Table 9, the estimated concentrations of peroxide compare well with those determined from the oxygen solubility measurements of Appleby and Van Drunen (56) and Ramaswami (65). The theoretical values of peroxide concentration in pure lithium carbonate melt, estimated from thermodynamic data (22) are much smaller than those determined by experiment. The discrepancy bitween the theoretical and experimental data is due to large uncertainty involved in the thermodynamic data for the molten alkali carbonates. The plots to determine reaction order with respect to oxygen for the product $\mathrm{D}_{\mathrm{O}}^{1 / 2} \mathrm{C}_{\mathrm{O}}$ are shown in Fig. 29. The reaction orders obtained are consistent with those obtained from cyclic voltammetric measurements. As demonstrated in Table 10. the oxygen reaction orders for the peroxide formation and the exchange current density for oxygen reduction. determined ix cyclic voltammetric and electrochemical impedance spectroscopic techniques. are compared in good agreement with the theoretical values.

\section{Conclusions}

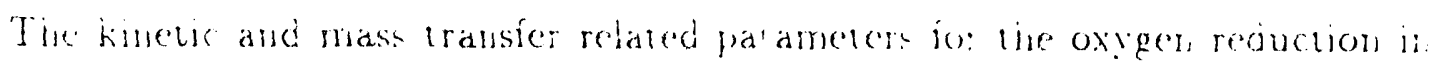

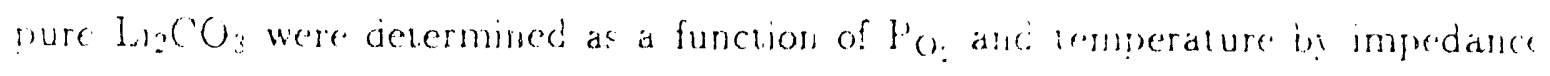

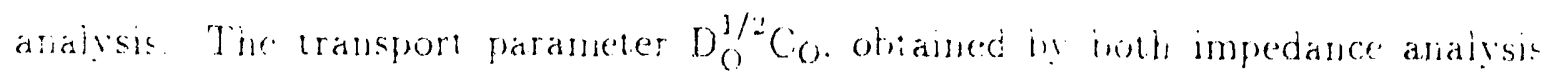

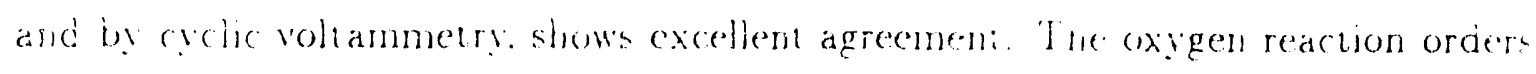




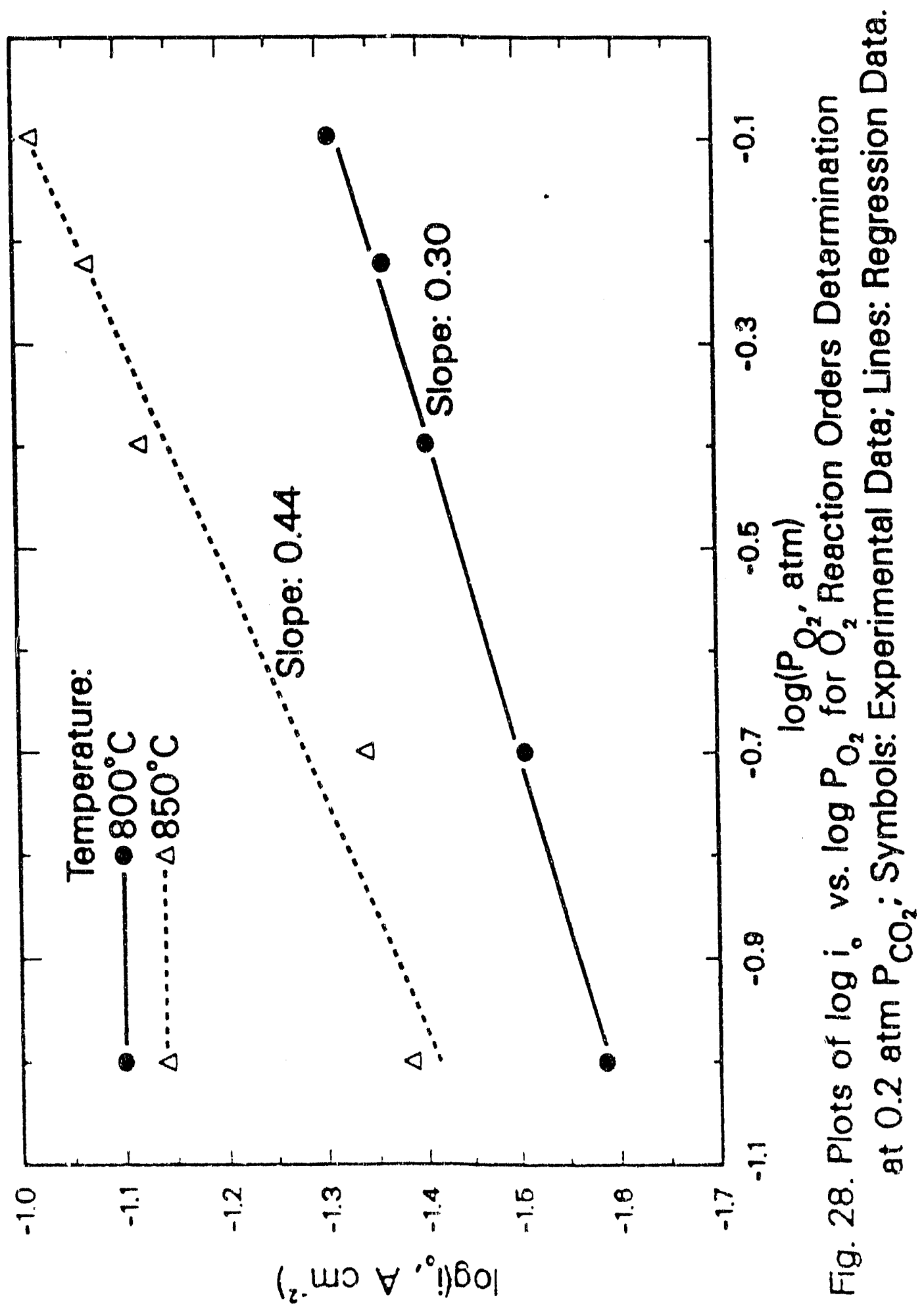




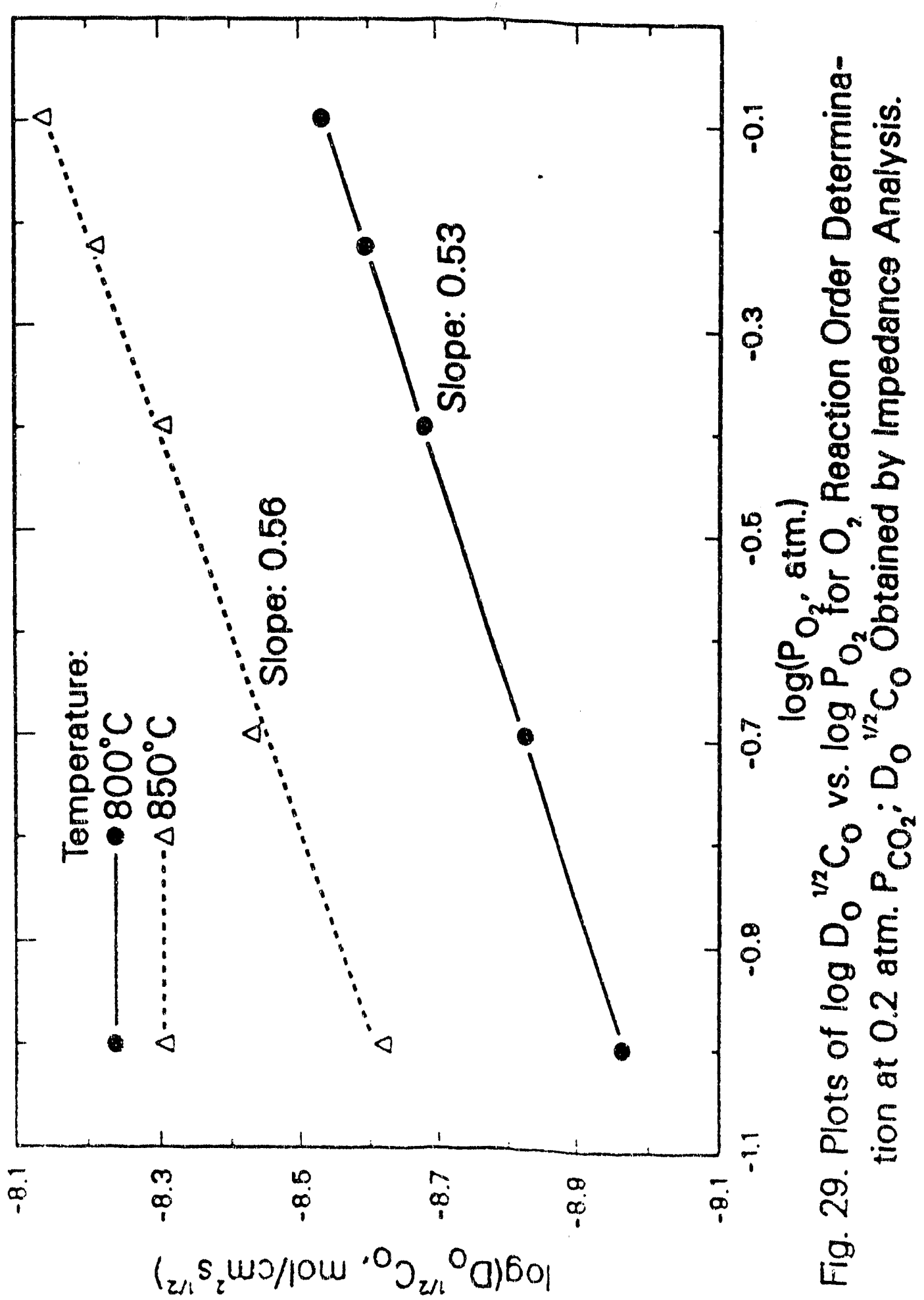


Table 9. Comparison of the Peroxide Concentration Determined from $D_{O}^{1 / 2} C_{O}$ Values (for $D_{O}=1 \times 10^{-5} \mathrm{~cm}^{2} \mathrm{~s}^{-1}$ ) with Literature Values and Thermodynarnic Data at $800^{\circ} \mathrm{C}$ Temperature and 0.2 atm $\mathrm{P}_{\mathrm{CO}_{2}}$.

\begin{tabular}{|c|c|c|c|c|}
\hline & \multicolumn{4}{|c|}{$\begin{array}{c}\mathrm{CO}_{0} \times 10^{7} \\
\text { mol cm }\end{array}$} \\
\hline $\begin{array}{c}\mathrm{P}_{\mathrm{O}_{2}} \\
\text { atm }\end{array}$ & $\begin{array}{c}\text { Electrochemical } \\
\text { Impedance } \\
\text { Spectroscopy }\end{array}$ & $\begin{array}{c}\text { Ramaswami } \\
(20)\end{array}$ & $\begin{array}{c}\text { Appleby and } \\
\text { Van Drunen } \\
(19)\end{array}$ & $\begin{array}{c}\text { Thermodynamic } \\
\text { Data } \\
(21)\end{array}$ \\
\hline 0.1 & 3.41 & 3.50 & 2.90 & 0.72 \\
0.2 & 4.71 & 4.95 & 4.10 & 1.02 \\
0.6 & 6.55 & 7.00 & 5.80 & 1.44 \\
0.8 & 8.53 & 8.57 & 7.10 & 1.76 \\
\hline 0.74 & 9.89 & 8.20 & 2.03 \\
\hline
\end{tabular}


Table 10. The Reaciior Order with Respect to Oxygen for the Exchange Current Density and $D_{O}^{1 / 2} C_{O}$ Estimated by Cyclic Voltammetry and Electrochemical Impedance Spectroscopy.

\begin{tabular}{|c|c|c|c|c|}
\hline Parameter & Techrique & $\begin{array}{l}\text { Temperature } \\
{ }^{\circ} \mathrm{C}\end{array}$ & $\begin{array}{l}\text { Estimated } \\
\mathrm{O}_{2} \text { Reaction } \\
\text { Order }\end{array}$ & $\begin{array}{c}\text { Theoretical } \\
\mathrm{O}_{2} \text { Reaction } \\
\text { Order }\end{array}$ \\
\hline \multirow{4}{*}{$D_{0}^{1 / 2} C_{0}$} & \multirow{2}{*}{$\begin{array}{l}\text { Electrochemical } \\
\text { Impedance } \\
\text { Spectroscopy }\end{array}$} & 800 & $0.53 \pm 0.02$ & \multirow{4}{*}{0.50} \\
\hline & & 850 & $0.56 \pm 0.11$ & \\
\hline & \multirow{2}{*}{$\begin{array}{c}\text { Cyclic } \\
\text { Voltammetry }\end{array}$} & 800 & $0.48 \pm 0.01$ & \\
\hline & & 850 & $0.51 \pm 0.07$ & \\
\hline \multirow{2}{*}{$i_{1}$} & \multirow{2}{*}{$\begin{array}{c}\text { Electrochemical } \\
\text { Impedance } \\
\text { Spectroscopy }\end{array}$} & 800 & $0.30 \pm 0.03$ & \multirow{2}{*}{0.38} \\
\hline & & 850 & $0.44 \pm 0.18$ & \\
\hline
\end{tabular}


resulting from the mass transfer parameters and the exchin... current densities at $800^{\circ} \mathrm{C}$, were determined to be 0.5 and 0.30 respectively. Thesic values are consistent with the peroxide reduction mechanisn proposed by Applaty and Nicholson. 


\section{CHAPTER VI}

\section{EFFECTS OF PARTIAL PRESSURE OF CARBON DIOXIDE}

\section{Introduction}

The oxygen reduction reaction in molten alkali carbonate electrolytes has been studied for the past quarter century because of its vital role in the performance of the molten carbonate fuel cell. Borucka and Sugiyama $(43,44)$ studied the $\mathrm{O}_{2} / \mathrm{CO}_{2} / \mathrm{Au}$ electrode in a ternary $\left(43.5 \mathrm{~mol} \% \mathrm{Lj}: 31.5 \mathrm{~mol} \% \mathrm{Na}: 25.0 \mathrm{~mol}^{2}\right) \mathrm{CO}_{3}$ eutectic melt in the temperature range of $550-800^{\circ} \mathrm{C}$ and concluded the following: (i) the effects of the partial pressures of oxygen and carbon dioxide on the equilibrium potential show that the over-all reaction at equilibrium is:

$$
1 / 2 \mathrm{O}_{2}+\mathrm{CO}_{2}+2 e^{-}=\mathrm{CO}_{3}^{2-}
$$

and the equilibrium potential obevs the Nernst equation

$$
\mathrm{E}_{\mathrm{O}_{2}, \mathrm{CO}_{2} / \mathrm{CO}_{3}^{2-}}=\mathrm{E}_{\mathrm{O}_{2}, \mathrm{CO}_{2} / \mathrm{CO}_{3}^{2}-}^{\mathrm{O}}+\frac{\mathrm{RT}}{2 \mathrm{~F}} \ln \left(\mathrm{P}_{\mathrm{O}_{2}^{2}}^{1 / 2} \mathrm{P}_{\mathrm{CO}_{2}}\right)
$$

liil the micropolarization tests at near-equilibrium indicate that the electrode is under "nixed" control. due to charge transier and the mass transport processes even close 16. the equilibrium potentiai: and (iii) the exchange densily for the electrocie reaction

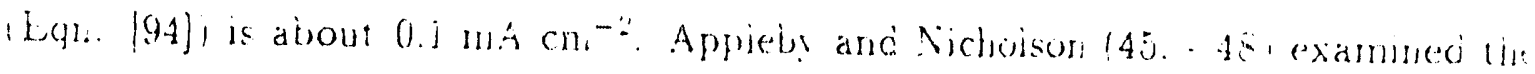

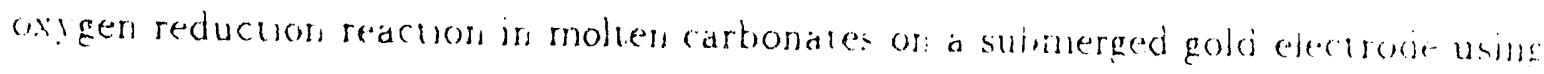

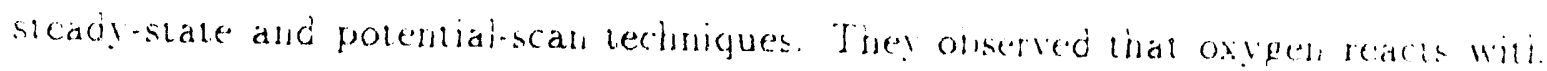
cartionate ions and forms peroxide and /or superoxice bons and the concentanano of

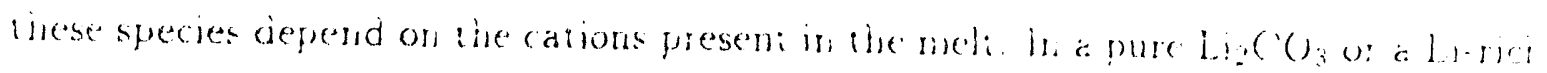

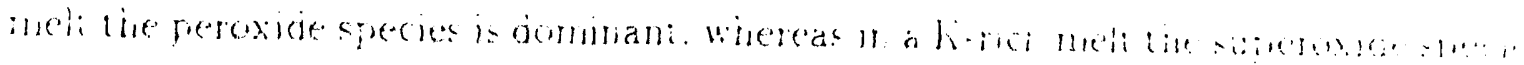




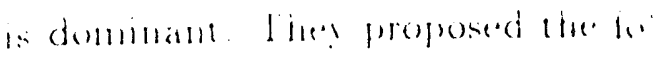

in pure litidun carbonate melt:

The overall reaction is

$$
\begin{aligned}
& 1 / 20: \cdot 1 \cdots=0 ?-(1): \\
& \text { () } \quad \cdots^{-}=\left(0^{-}\right)+()^{2-} \\
& \left(\mathrm{O}^{-}\right)+\left(\mathrm{C}^{\prime}\right): \mathrm{C}^{-}=\mathrm{CO} \mathrm{O}_{3}^{2} \\
& 0^{2} \quad 1^{\prime}()_{2}=\mathrm{CO}:
\end{aligned}
$$

$$
1 / 2 \mathrm{O}_{2}+\mathrm{C}(1) \quad 1 \ldots-\mathrm{CO}_{3}^{2-}
$$

where $\left(\mathrm{O}^{-}\right)$is a transient species. $\Lambda_{1} \ldots$.'ding to this raction mechanism, the first charge transfer step (Eqn. [97]) ' ' '.1. determininf. for an immersed electrode.

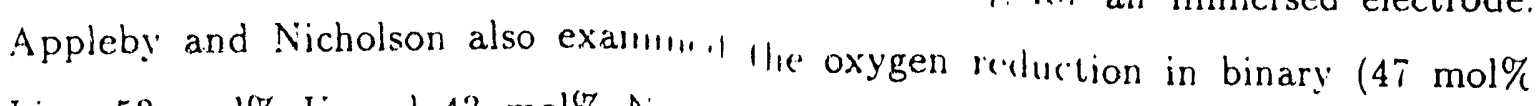
$\mathrm{Li}: 53 \mathrm{~mol} \% \mathrm{~K}$ and $43 \mathrm{~mol} \% \mathrm{~N}_{\text {. }} \quad$ ii mol\% $\mathrm{h}$ ) and ternary $(43.5 \mathrm{~mol} \% \mathrm{Li}$ : $31.5 \mathrm{~mol} \% \mathrm{Na}: 25 \mathrm{~mol} \% \mathrm{~K}$ ) $\mathrm{cul} .1$, in the temprelature range of $700-800{ }^{\circ} \mathrm{C}$ and concluded that: (i) the elect......... species is no the oxygen molecule: (ii) both peroxide and superoxide ion...." l...sent and are loduced in the parallel steps: and (iii) the neutralization of the ".... "ms by carben dicxide (Eqn. [99]) is slow. Andersen (22) carried out a them.... nimic study on the chemical equilibria in molten alkali carbonate electrolyı. .... l.mnonstrated /he presence of peroxide ions 11. quenching experimemts follower: : . ". mical anaigse Appleby an Van Drunen

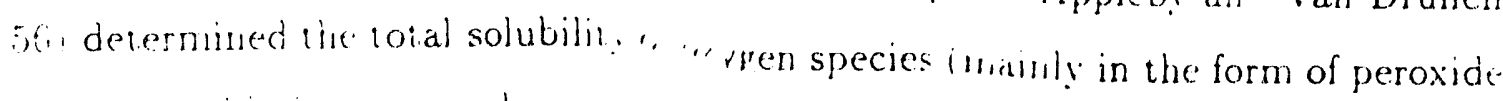

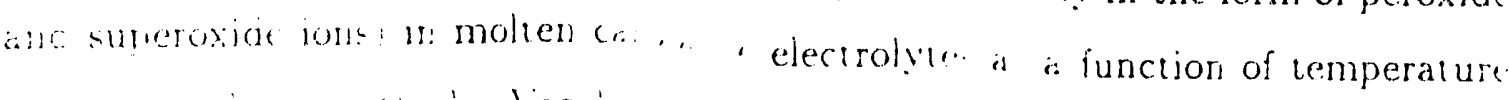

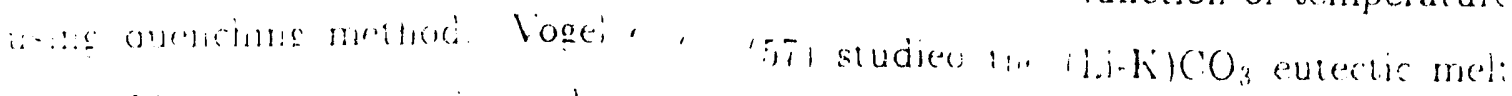

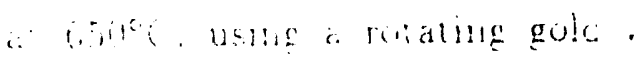
- " concluder lia' superoxicie is domrian:

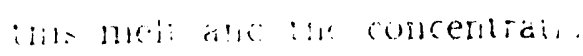

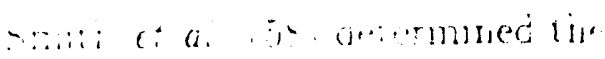

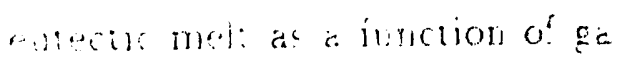

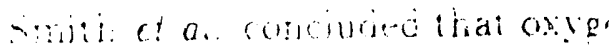

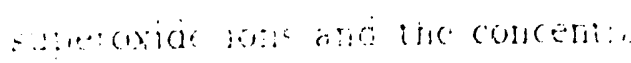

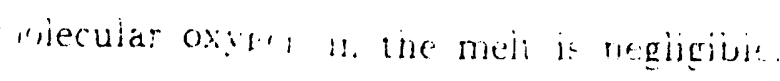

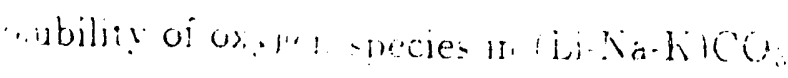

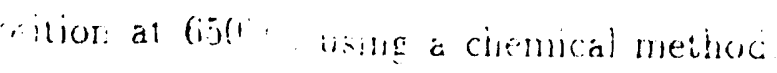

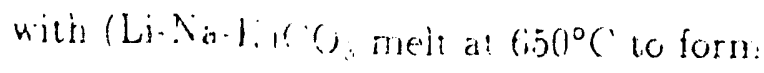

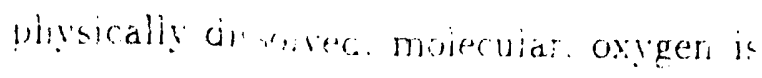


Dunks and Stelman (53) studied the oxygen reduction mechanism in pure sodium carbonate at $900^{\circ} \mathrm{C}$, using cyclic voltammetric and computer-curve Fuing and proposed the existence of percarbonate jons. They also confirmed the wence of superoxide ion in the frozen electrolyte by Electron Spin Resonance (ESR) anctrum at $77 \mathrm{~K}$ temperature. Lu (23) investigated oxygen reduction kinetics in $\mathrm{Li}_{2} \mathrm{CO}_{3}$ and a $\mathrm{Li}-\mathrm{K}(62 \mathrm{~mol} \%: 38 \mathrm{~mol} \%)$ carbonate eutectic mixture using the fotential step method. 'The exchange current density, determined by $\mathrm{Lu}\left(39 \mathrm{~mA} / \mathrm{cm}^{2}\right.$ $90 \% \mathrm{O}_{2}$ and $10 \% \mathrm{CO}_{2}$ at $750^{\circ} \mathrm{C}$ in $\mathrm{Li}_{2} \mathrm{CO}_{3}$ melt), is two orders of magnitude ther than that reported by Appleby and Nicholson $\left(0.34 \mathrm{~mA} / \mathrm{cm}^{2}\right)$, who used the Folential scan technique. But the dependence of oxygen reduction kinetics on partial presures of oxygen and carbon dioxide observed by Lu could not be explained by Sor of the mechanism proposed in the literature. Uchida et al. (61) determined the elecirode kinetic parameters for oxygen reduction on a gold electrode in a ( $\mathrm{Li}$ (3)C.O, 4.42 .7 mol\%:57.3 mol\%) eutectic melt using impedance analysis, potential and coulostatic relaxation techniques. They found that the exchange current densily was about the same order of magnitude as that reported by Lu. In addition, Fuse concluded that of the three methods for the determination of the electrode Hnelic parameters for oxygen reduction in molten carbonates, the electrochemical mpedance analysis is the most reliable. Uchida et al. (62) examined the oxygen Foduction mechanism on a lithiated $\mathrm{NiO}$ film, deposited on gold, and $\mathrm{Sb}$-doped $\mathrm{SnO}_{2}$ Sectrodes in Li-K eutectic melt by impedance spectroscopy and coulostatic relaxation Zeconsque: They (63) also determined the temperature dependence of the electrode Funcus and miss transfer related parameters for oxygen reduction on gold in ( $\mathrm{Li}$ -

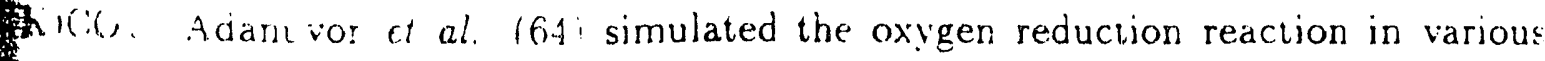
Har. cathate melts: this mathematical model considered the simulianeous presence

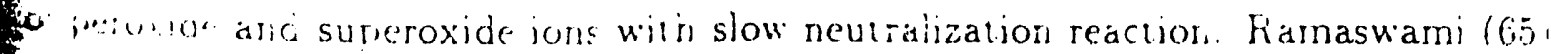
Su-c a ruabure dist electrode made of gold to study the oxygen reciuction reaction! 75. pure lisisum cartonate melt at $800^{\circ} \mathrm{C}$. and determined the difiusion coefficieni Enderila: lon concentration as a function of the partial pressure of oxygen 
Even though these studies have yielded valuable information, the mirchaof oxygen reduction in molten carbonate is still not well understoml: fursome of the results reported in the literature are not consistent. Provious $(22,46,56,58)$ show that the presence of physically dissolved nolecuaxygen in molten carbonate electrolyte is insignificant. This is true liccause zen reacts with the molten alkali carbonates to form peroxide and/or superoxions, the concentrations of which depend on the calions present in thr melt. mormodynamic data (22) indicate that the equilibrium concentration of the supaxide ion decreases with a decrease in the ionic radii of the alkali cations (i.e., - decreases in the order $\mathrm{K}_{2} \mathrm{CO}_{3}>\mathrm{Na}_{2} \mathrm{CO}_{3}>\mathrm{Li}_{2} \mathrm{CO}_{3}$ ), and in a pure lithium carmale melt the superoxide ion is unstable. Consequently. in the this work, we have Fed a pure lithium carbonate melt to avoid the complexity of simultaneous cxistence peroxide and superoxide ions. The effects of the partial pressure of oxygen and annerature on electrode kinetics and mass transfer parameters for oxygen reducfon in pure lithium carbonate melt were descrilied in the previous chapters. In this Hapter. the influence of partial pressure of carlion dioxide on the oxygen reduction Finetics was investigated using electrochemical impedance spectroscopy (VIS) and Fyclic voltammetry. Also, the temperature dependence of oxygen reduction kinetic was examined.

F.xpi imental

The experimental setup for high temperature electrode kinetic study and methodolog! arr as described in Chapter III. The working electrode was made of a submrrged gold Pag $(0.0 \mathrm{mi}$ thich). with a geometrical are of one square centimeter, connected to we gold current collector $\left(0^{5}=\mathrm{nm}\right.$ diameles) by a thin gold wire to minimize the

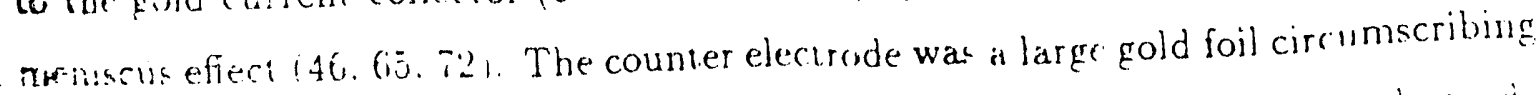
the working electrode consure uniform current distritution. Tise reference electrode

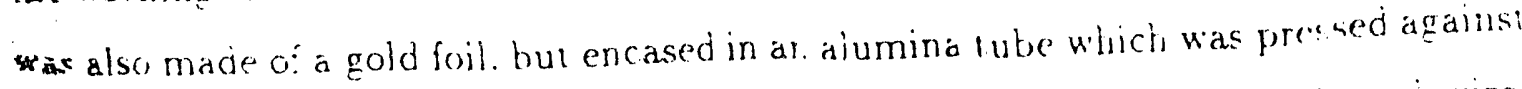
the houm of the electrochemical cell. The high purity (99.9\%) gold foil- and wires tore ohained irom Johnson Matthey/ ESAL Group, 
Digital mass flow controllers/meters manufactured by Teledyne-Hastings Raywere used to provide the gas mixtures of the desired compositions $\left(\mathrm{O}_{2}, \mathrm{CO}_{2}\right.$, and ) with high precision ( $\pm 1 \%$ Full Scale). The high purity gases were obtained from Butheson Gas Products and the traces of water were removed by passing the blended L through a column of $5 \AA$ molecular sieves and Drierite (Fisher Scientific). The gas Finure was bubbled into the melt in the vicinity of the working electrode at a flow of $50 \mathrm{~cm}^{3} \mathrm{n: \textrm {in } ^ { - 1 }}$ through a long alumina tube with four holes. The composition the gas mixture supplied to the reference electrode compartment was the same as we used for the working electrode, but at a lower flow rate $\left(5 \mathrm{~cm}^{3} \mathrm{~min}^{-1}\right)$. In this Aody, $\mathrm{PCO}_{2}$ was varied from 0.02 to 0.4 atm, while $\mathrm{PO}_{2}$ was maintained constant at $76 \mathrm{sm}$. The total pressure was $1 \mathrm{~atm}$, by varying the partial pressure of argon. The High purity (99.999\%) lithium carbonate (Alfa Products) was carefully weighed in alumina crucible $(90 \mathrm{ml}$ capacity) and the electrochemical cell was slowly heated

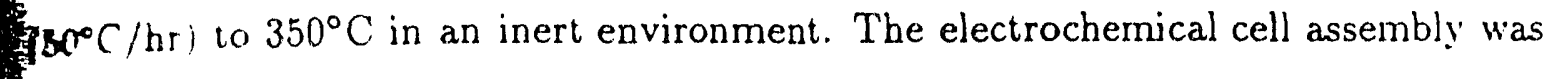
tried at $350^{\circ} \mathrm{C}$ in a carbon dioxide environment for 24 hours prior to increasing its gemperature to $800^{\circ} \mathrm{C}$.

The data acquisition set-up consisting of a potentiostat/galvanostat (Model 3, lock-in-amplifier (Model 5301A), personal computer (IBM PS/2), and software Wodel 378) supplied by EG\&G Princeton Applied Research was used for the cyclic Toltammetric and electrochemical impedance spectroscopic experiments. The EIS Fxasurements were made over a wide range of frequencies $(0.05 \mathrm{~Hz}$ to $10 \mathrm{kHz})$ for Gtir suusoidal excitation signal ( $5 \mathrm{mV}$ rms), because the capacitive effect, attributed we lim: doubie laver, is significant at high frequency while the diffusional (Warburg) wr: wance is o minant ai low frequency. The impedance measurements for frequenFors ligher than $5 \mathrm{~Hz}$ were carried out by the Phase Sensitive Detection (PSD) techF... using the loch-in-amplifier and the potentiostat. For frequencies below $5 \mathrm{~Hz}$ the Er? inpeance was measured by the Fast Fourier Transform (FFT) technque using. Etorsonai computer and potentiostat. The low frequency measurements (bejow j Eir refresen: the average values of 15 data cycles. which were necessary to improve 
accurac! of the data by averaging out the noisc interference. The amplitude of excitation signal was kept at $5 \mathrm{mV}$ to ensure a linear electrochemical response.

rochemical Impedance Measurements and Analyses

impedance spectra, for oxygen reduction on the submerged gold electrode in hium carbonate melt at the equilibrium potential, were obtained as a function $\mathrm{PCO}_{3}$ and temperature. As described in the previous chapters, the absence of micircle in the complex plane impedance plot indicates fast oxygen reduction ipetics (98). In the region of low frequency, the complex plane plot showed a linear hevior with a slope of $45^{\circ}$ due to the Warburg impedance (88). The effect of arial pressure of carbon dioxide on the Bode plot, phase angle vs. log $\omega$, at 30. 800. and $850^{\circ} \mathrm{C}$ are shown in Figs. 30, 31, and 32, respectively. In the high requency region, the phase angle approached $0^{\circ}$ for all plots, indicating a purely existive behavior of the cell impedance. The impedance at $0^{\circ}$ phase angle is a mosure of the uncompensated electrolyte resistance, $R_{s}$, between the working and the reference electrodes. At frequencies below $30 \mathrm{~Hz}$, the phase angle approached $4 \%$, . indicating that the diffusional impedance is significant. The influence of partial pressure of carbon dioxide on oxygen reduction kinetics is evident at the intermediate freoucncies, i.e., the charge transfer resistance increases with increase of $\mathrm{PCO}_{2}$. The thary deviations in the Bode plots at about $120 \mathrm{~Hz}(\log \omega \approx 2.88)$ can not be explained this time. It may be possible that a flaw exists in the experimental equipment.

The impedance spectra were resolved by using the Randles-Ershler equivalent forr:ui: (83. 84) model shown in Fig. 4. The Randles-Ershler equivalent circuit retherl: i wo paralle! process occurring at the electrode-electrolyte interface, namely: fu:" noutufe layn charging and the faradaic reaction. The faradaic impedance conf:- : : : we chatec ransier resistance which is in series with the Warburg (difiusionali

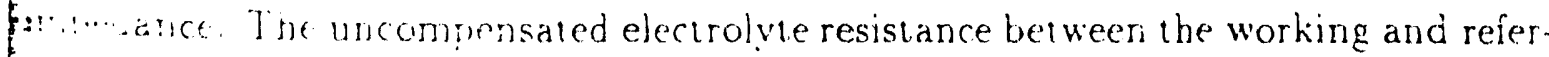

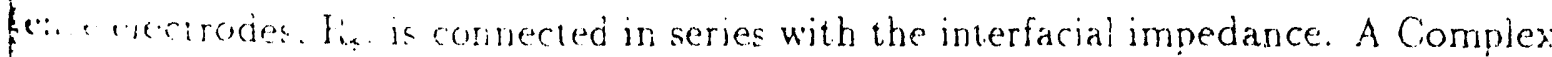
t.

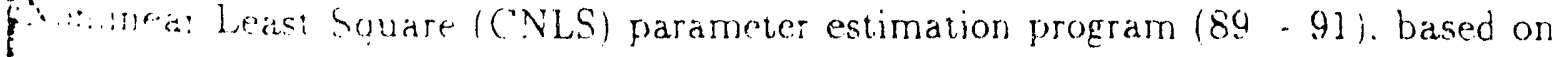
Areatere Marquardi ajgcrithmi. was used to resolve the impedance spectra. In our 


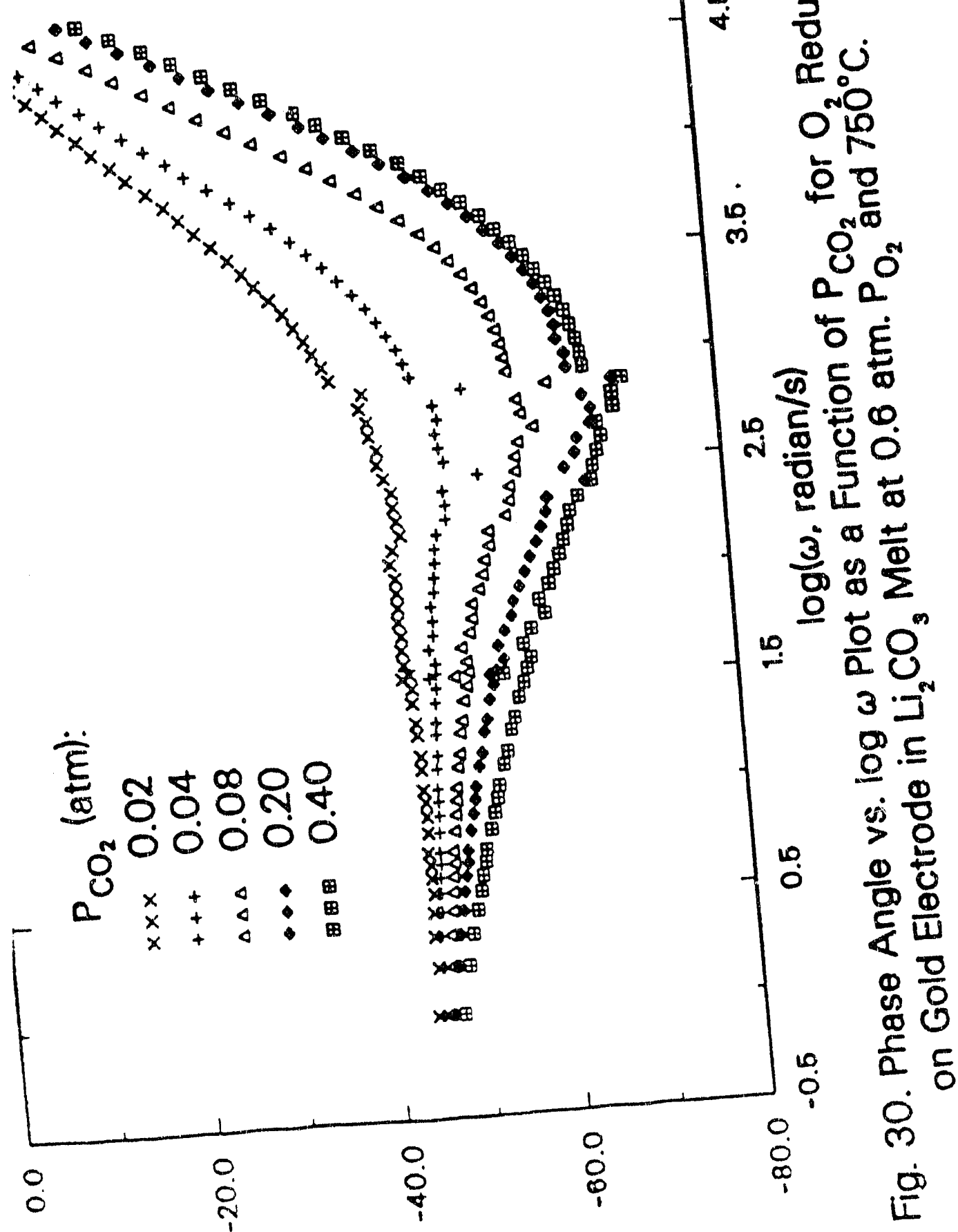

(sәaлbap) өןbur aseud 


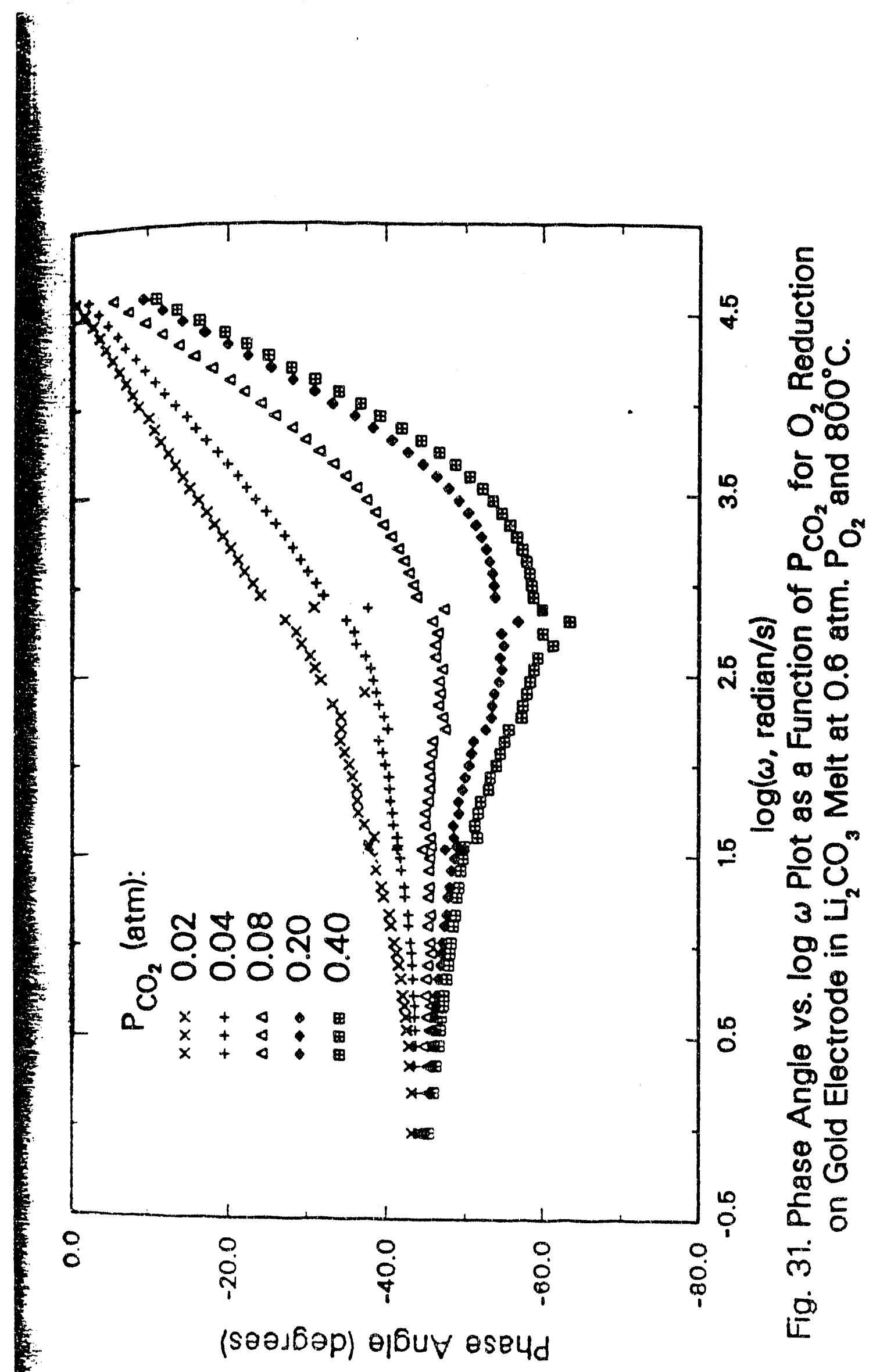




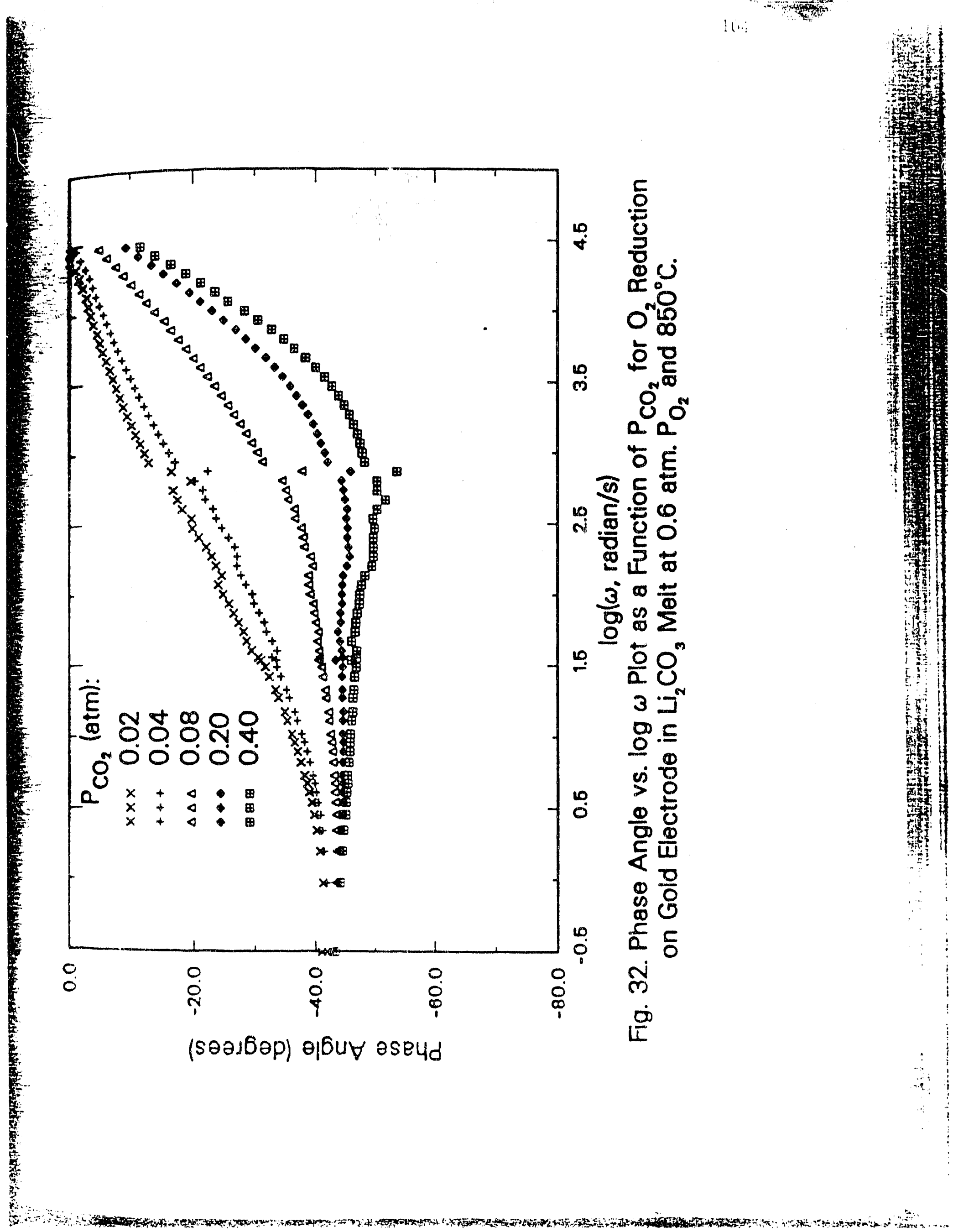


we found that the weighting factor (inverse of the error variance) considerinfluenced the accuracy of the parameters estimated from the impedance data. we have used the proportional and functional proportional weighting factors to determine the electrode kinetic and the mass transfer parameters This analvields parameters such as the charge transfer resistance, double layer capacity, burg coefficient, and uncompensated electrolyte resistance. The parameter esftion by the complex nonlinear least square method also provides the standarc fation of the estimated parameters.

The effects of partial pressure of carbon dioxide on real part of impedance $\left(Z^{\prime}\right)$ inverse square root of angular frequency $\left(\omega^{-1 / 2}\right)$ at $750,800,850^{\circ} \mathrm{C}$ temperatures show'n in Figs. 33, 34, and 35, respectively. In the low frequency region, $Z^{\prime}$ .$^{-1 / 2}$ plots showed a linear behavior with a slope proportional to the Warburg efficient $(\sigma)$. As demonstrated in Figs. 33, 34, and 35, the Warburg coefficient treases with an increase of $\mathrm{P}_{\mathrm{CO}_{2}}$. This result can be rationalized easily because ah increase of $\mathrm{PCO}_{2}$, there is a decrease in the peroxide ion concentration (Equ. 3] : and the Warburg coefficient is inversely proportional to the concentration of 3. diffusing species. The predicted impedance values in Figs. 33, 34, and 35, Aculated using the estimated parameters values given in Tables 11- 13 and the Indies. Ershler equivalent circuit model, agree well with the experimental data. The oxtrode kinetic and mass transfer parameters as function of $\mathrm{P}_{\mathrm{CO}_{2}}$. for temperatures o. 80 : and $850^{\circ} \mathrm{C}$, are presented in Tables $11-13$, respectively. As shown in ese tables. a decrease in $\mathrm{P}_{\mathrm{CO}_{2}}$ from 0.4 to 0.02 atm caused a ...n fold decrease in nirgnitucie of the Warburg coefficient. A similar trend was observed when the minaviure was increased from 750 to $850^{\circ} \mathrm{C}$. The charge transfer resistance also ten.... witi: 1: rease in temperature and decrease in partial pressure of carbon Fu:.... T1: acuitite laver capacity for the smooth gold electrode in a pure lithiun

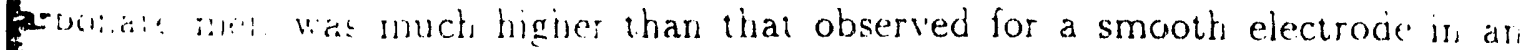

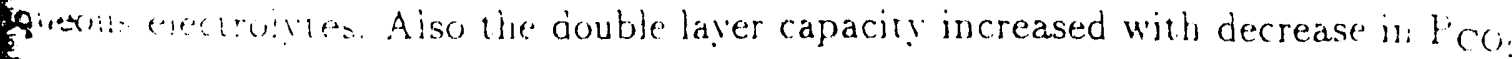
pe tim mercies was more significant at higher temperature. This dependence of

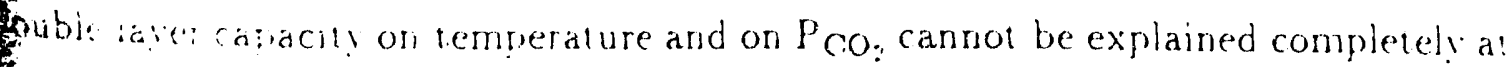


In point but it may be due to the formation of a solid oxide layer on the electrode. the change in the uncompensated electrolyte resistance with temperature and $\mathrm{P}_{\mathrm{CO}}$ : megligible. The effects of partial pressure of carbon dioxide on the plots of log 1 s. $\log \omega$ are shown in Figs. 36, 37, and 38. The $\log |Z|$ vs. $\log \omega$ plots averge to the value of uncompensated electrolyte resistance at high frequencies. the low frequency region, complete relaxation of the charge transfer process was observed due to the diffusional impedance. Also, it is evident from Fig. 4 that Te experimental data concurr with the model predictions for the entire frequency unge of the experiment. Since impedance measurements were obtained at the rest Fotential, the following expressions were used for calculations of the charge transfer Fesistance and the Warburg coefficient (80):

$$
\begin{gathered}
R_{c l}=\frac{R T}{n F i_{o}} \\
\sigma=\frac{R T}{n^{2} F^{2} A \sqrt{2}}\left(\frac{1}{D_{O}^{1 / 2} C_{O}}+\frac{1}{D_{R}^{1 / 2} C_{R}}\right)
\end{gathered}
$$

For peroxide reduction in $\mathrm{Li}_{2} \mathrm{CO}_{3}$ melt, $\mathrm{C}_{\mathrm{O}}$ is much smaller than $\mathrm{C}_{\mathrm{R}}$ because the final pproduct is carbonate ion. Therefore $1 / D_{R}^{1 / 2} C_{R}$ is negligible compared with $1 / D_{O}^{1 / 2} C_{O}$. Tbus Eqn. [102] can be approximated by the following expression:

$$
\sigma=\frac{\mathrm{RT}}{\mathrm{n}^{2} \mathrm{~F}^{2} \mathrm{~A} \sqrt{2}}\left(\frac{1}{\mathrm{D}_{\mathrm{O}}^{1 / 2} \mathrm{C}_{\mathrm{O}}}\right)
$$

The calculated values of the exchange current density and product. $\mathrm{D}_{0}^{1 / 2} \mathrm{C}_{\mathrm{O}}$. as functions of $\mathrm{FCO}_{2}$ and temperature, are given in Tables 11-14. The increase in partial fres-ur: or-bon dioxide decreases the electrode kinetics. e.g. the exchange current ucns:: aecreased more than five fold when the partial pressure of carbon dioxide was

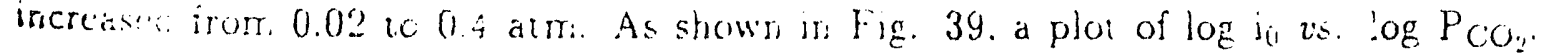
io: dition: iemperatures showed a linear henavior and the carbon dioxide reaction

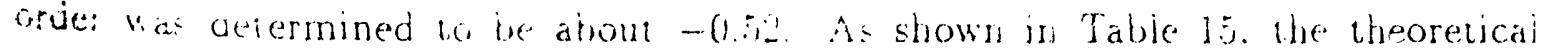

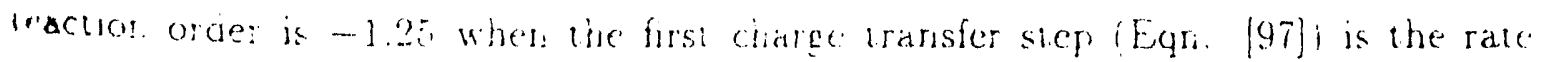
Acteming slep and the symetry factor $\beta$ is 0.5 . Thus. the reaction order of the

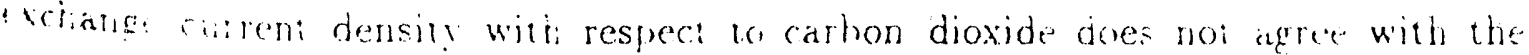



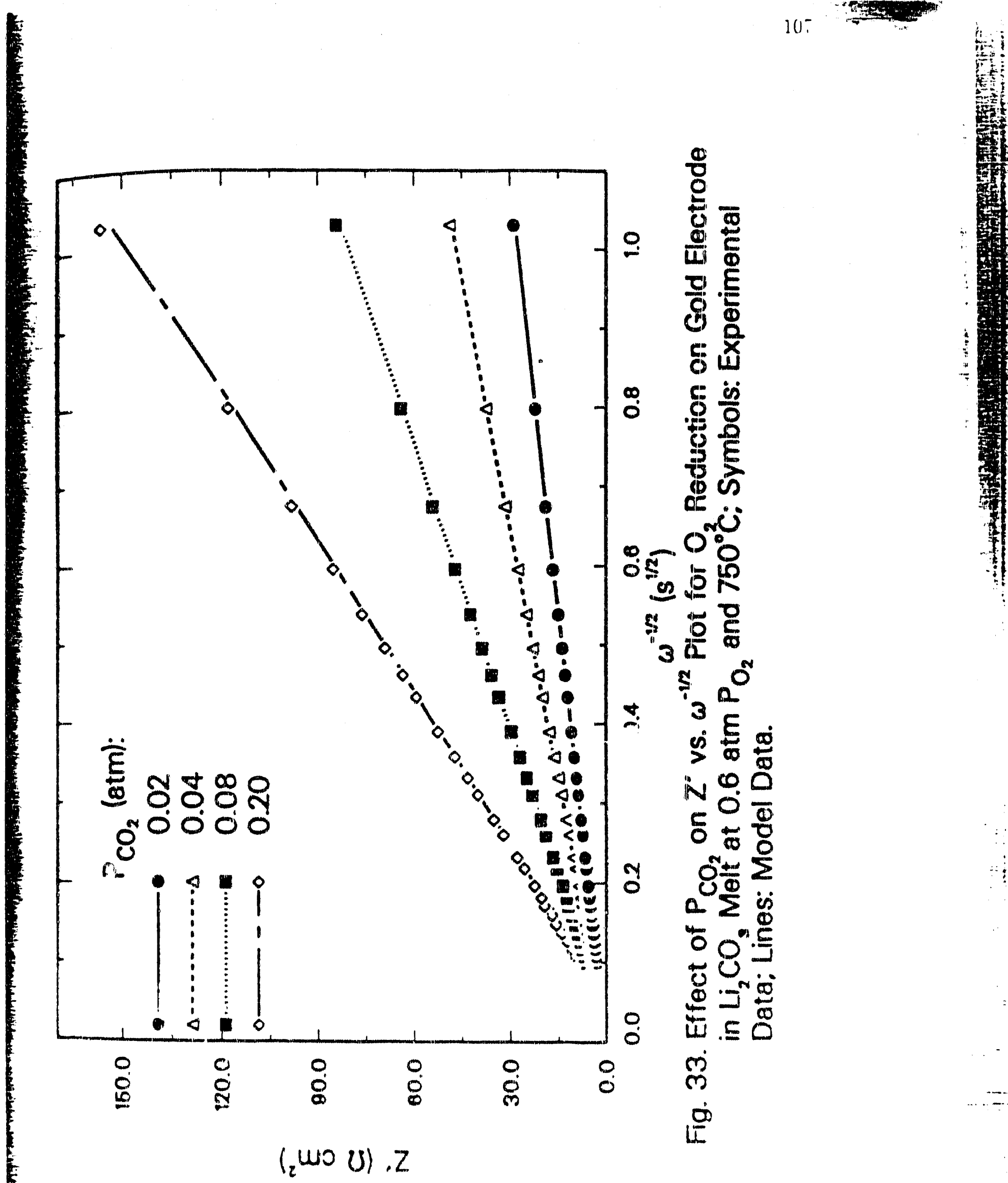

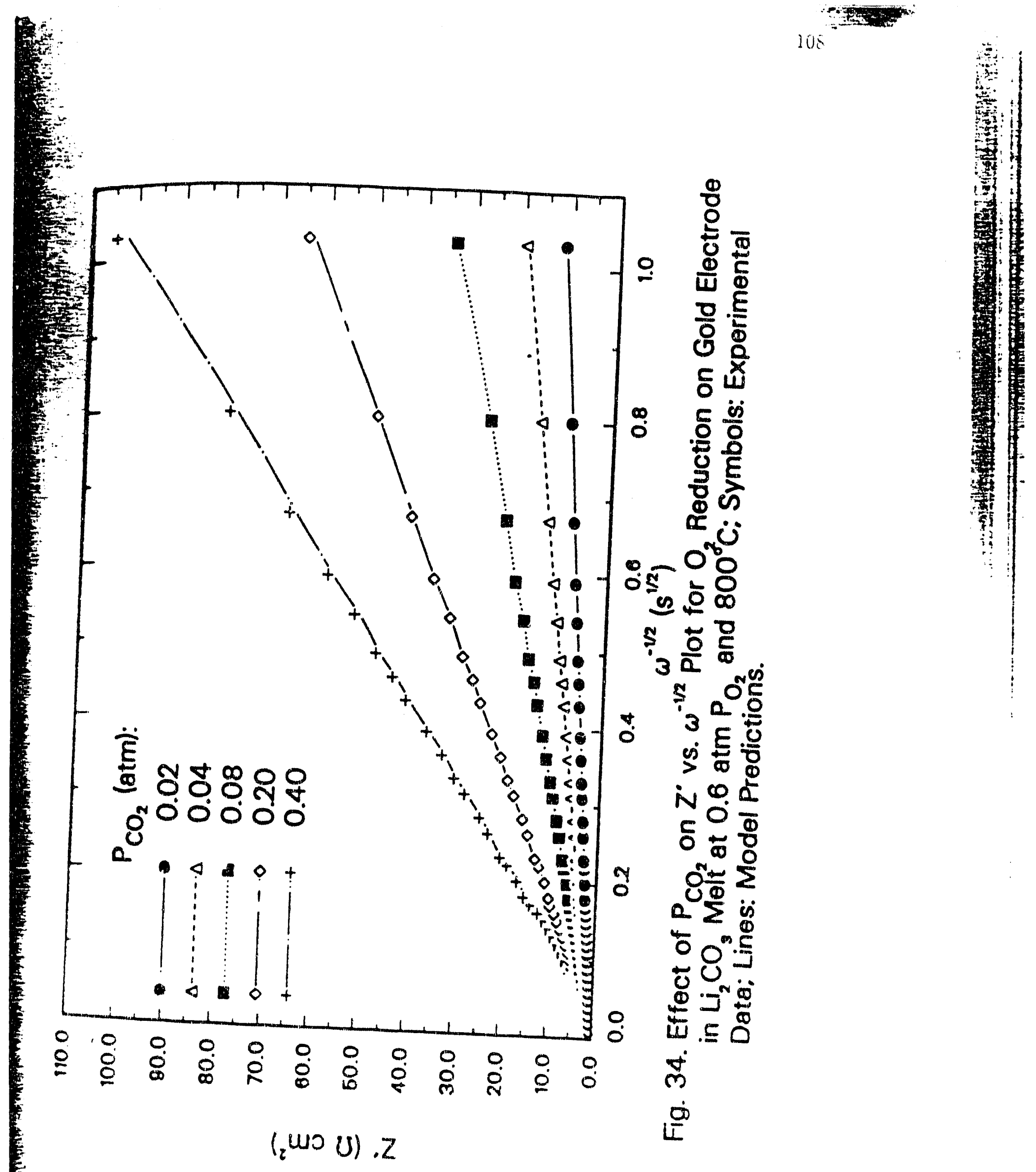

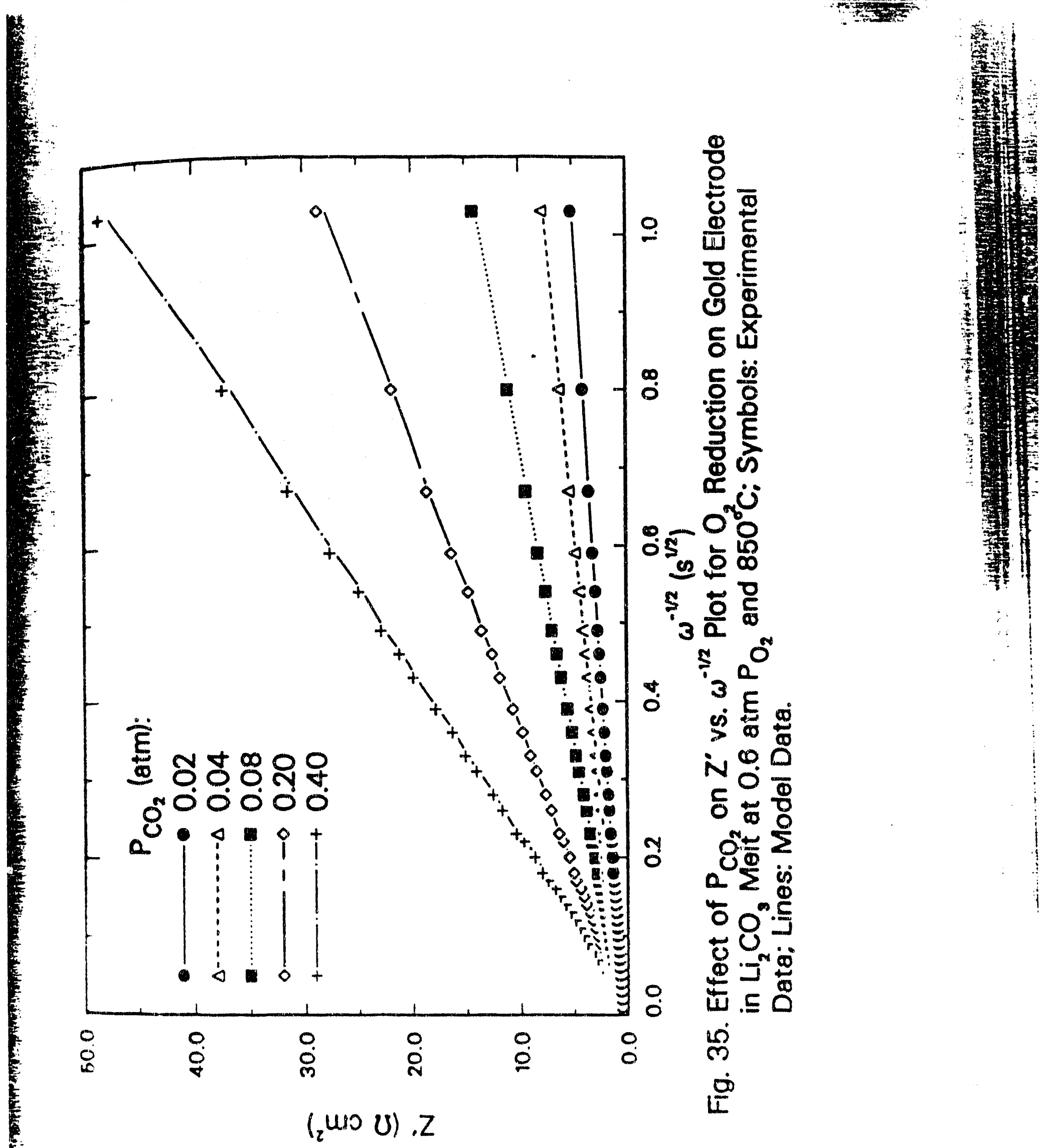


\begin{tabular}{|c|c|c|c|c|c|}
\hline \multicolumn{6}{|c|}{$\begin{array}{l}\text { Table 11. Effect of } \mathrm{PCO}_{2} \text { on Electrode Kinetic and Mass Transfer } \\
\text { Parameters Estimated by Electrochemical Impedance Spectroscopy a } \\
750^{\circ} \mathrm{C} \text { Temperature and } 0.6 \text { atm } \mathrm{PO}_{2} \text {. }\end{array}$} \\
\hline $\begin{array}{l}\mathrm{PCO}_{2} \\
\mathrm{~atm}\end{array}$ & $\begin{array}{c}\sigma \\
\Omega \mathrm{cm}^{2} \mathrm{~s}^{-1 / 2}\end{array}$ & $\begin{array}{c}R_{\mathrm{cl}} \\
\Omega \mathrm{cm}^{2}\end{array}$ & $\begin{array}{l}\text { io }_{0} \times 10^{3} \\
\mathrm{~A} \mathrm{~cm}\end{array}$ & 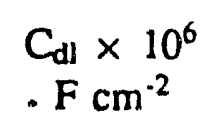 & $\begin{array}{c}\mathbf{R}_{\mathrm{b}} \\
\Omega \mathrm{cm}^{2}\end{array}$ \\
\hline 0.02 & $27.2 \pm 0.66$ & $0.53 \pm 0.06$ & $86.5 \pm 19.3$ & $560 \pm 27.6$ & 0.51 \\
\hline 0.04 & $47.1 \pm 0.85$ & $0.66 \pm 0.08$ & $70.1 \pm 17.2$ & $395 \pm 15.9$ & 0.50 \\
\hline 0.08 & $82.9 \pm 2.52$ & $1.07 \pm 0.26$ & $43.4 \pm 20.5$ & $313 \pm 17.0$ & 0.38 \\
\hline 0.20 & $156 \pm 9.35$ & $2.67 \pm 1.03$ & $17.4 \pm 13.1$ & $271 \pm 18.5$ & 0.36 \\
\hline
\end{tabular}


Table 12. Effect of $\mathrm{PCO}_{2}$ on Electrode Kinetic and Mass Transfer Parameters Estimated by Electrochemical Impedance Spectroscopy at $800^{\circ} \mathrm{C}$ Temperature and 0.6 atm $\mathrm{Po}_{2}$.

\begin{tabular}{|c|c|c|c|c|c|}
\hline $\begin{array}{c}\mathrm{PCO}_{\mathrm{Cm}} \\
\mathrm{atm}\end{array}$ & $\begin{array}{c}\sigma \\
\Omega \mathrm{cm}^{2} \mathrm{~s}^{-1 / 2}\end{array}$ & $\begin{array}{c}\mathrm{R}_{\mathrm{cl}} \\
\Omega \mathrm{cm}^{2}\end{array}$ & $\begin{array}{c}\mathrm{i}_{0} \times 10^{3} \\
\mathrm{~A} \mathrm{~cm}^{-2}\end{array}$ & $\begin{array}{c}\mathrm{C}_{\mathrm{dl}} \times 10^{6} \\
\mathrm{~F} \mathrm{~cm}\end{array}$ & $\begin{array}{c}\mathrm{R}_{\mathrm{s}} \\
\Omega \mathrm{cm}^{2}\end{array}$ \\
\hline 0.02 & $10.3 \pm 0.34$ & $0.25 \pm 0.06$ & $187 \pm 46.2$ & $1250 \pm 83.4$ & 0.50 \\
0.04 & $18.3 \pm 0.52$ & $0.42 \pm 0.09$ & $111 \pm 24.7$ & $729 \pm 41.5$ & 0.53 \\
0.08 & $31.7 \pm 1.06$ & $0.58 \pm 0.18$ & $79.4 \pm 24.6$ & $509 \pm 31.6$ & 0.37 \\
0.20 & $63.2 \pm 1.37$ & $0.84 \pm 0.25$ & $55.3 \pm 16.8$ & $330 \pm 14.1$ & 0.37 \\
0.40 & $100 \pm 4.56$ & $1.43 \pm 0.91$ & $32.3 \pm 20.5$ & $282 \pm 19.3$ & 0.40 \\
\hline
\end{tabular}


Trable 13. Effect of $\mathrm{PCO}_{2}$ on Electrode Kinetic and Mass Transfer Parameters Estimated by Electrochemical Impedance Spectroscopy at $850^{\circ} \mathrm{C}$ Temperature and 0.6 atm $\mathrm{PO}_{2}$.

\begin{tabular}{|c|c|c|c|c|c|}
\hline $\begin{array}{c}P_{\mathrm{CO}_{2}} \\
\mathrm{~atm}\end{array}$ & $\begin{array}{c}\sigma \\
\Omega \mathrm{cm}^{2} \mathrm{~s}^{-1 / 2}\end{array}$ & $\begin{array}{c}\mathrm{R}_{\mathrm{cl}} \\
\Omega \mathrm{cm}^{2}\end{array}$ & $\begin{array}{c}\mathrm{i}_{0} \times 10^{3} \\
\mathrm{~A} \mathrm{~cm}\end{array}$ & $\begin{array}{c}\mathrm{C}_{\mathrm{dl}} \times 10^{6} \\
\mathrm{~F} \mathrm{~cm}\end{array}$ & $\begin{array}{c}\mathrm{R}_{\mathrm{s}} \\
\Omega \mathrm{cm}^{2}\end{array}$ \\
\hline 0.02 & $4.31 \pm 0.16$ & $0.14 \pm 0.02$ & $337 \pm 75.1$ & $3220 \pm 225$ & 0.51 \\
0.04 & $6.88 \pm 0.23$ & $0.18 \pm 0.02$ & $265 \pm 62.3$ & $1880 \pm 132$ & 0.59 \\
0.08 & $13.3 \pm 0.30$ & $0.27 \pm 0.03$ & $177 \pm 32.5$ & $891 \pm 48.1$ & 0.39 \\
0.20 & $27.0 \pm 0.57$ & $0.47 \pm 0.05$ & $103 \pm 20.1$ & $411 \pm 23.8$ & 0.37 \\
0.40 & $46.2 \pm 1.65$ & $0.71 \pm 0.11$ & $67.8 \pm 20.3$ & $390 \pm 19.3$ & 0.40 \\
\hline
\end{tabular}




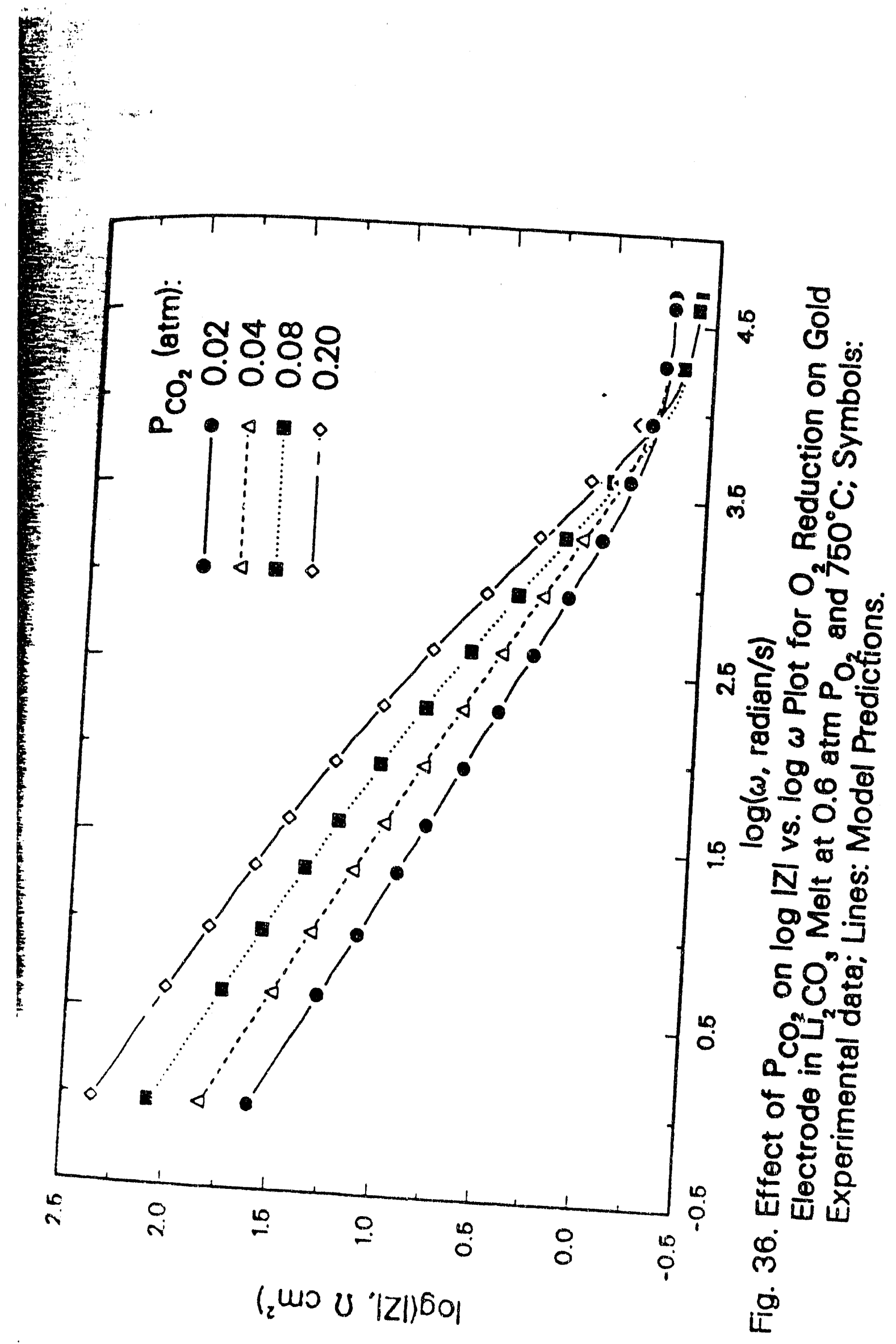





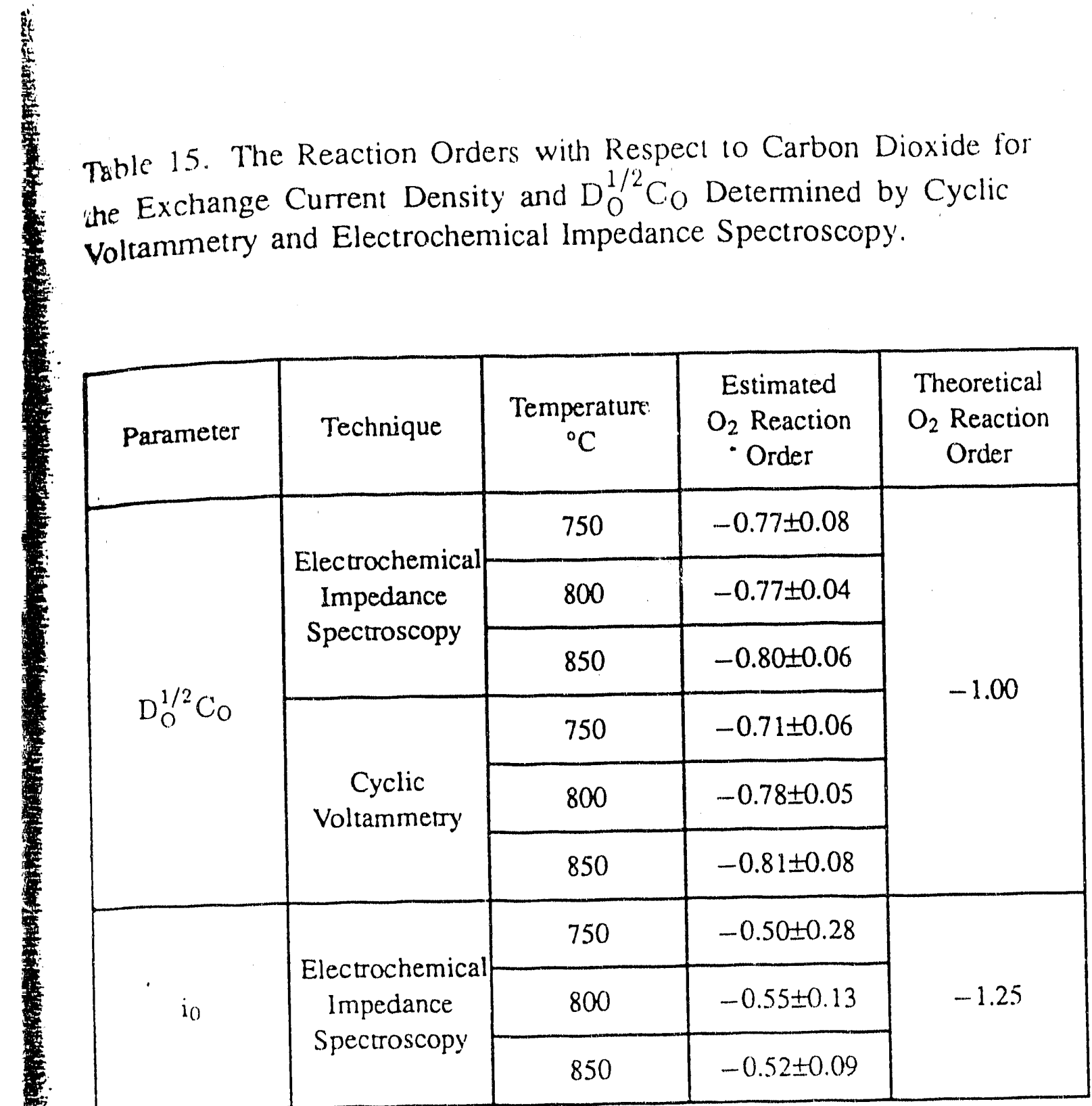



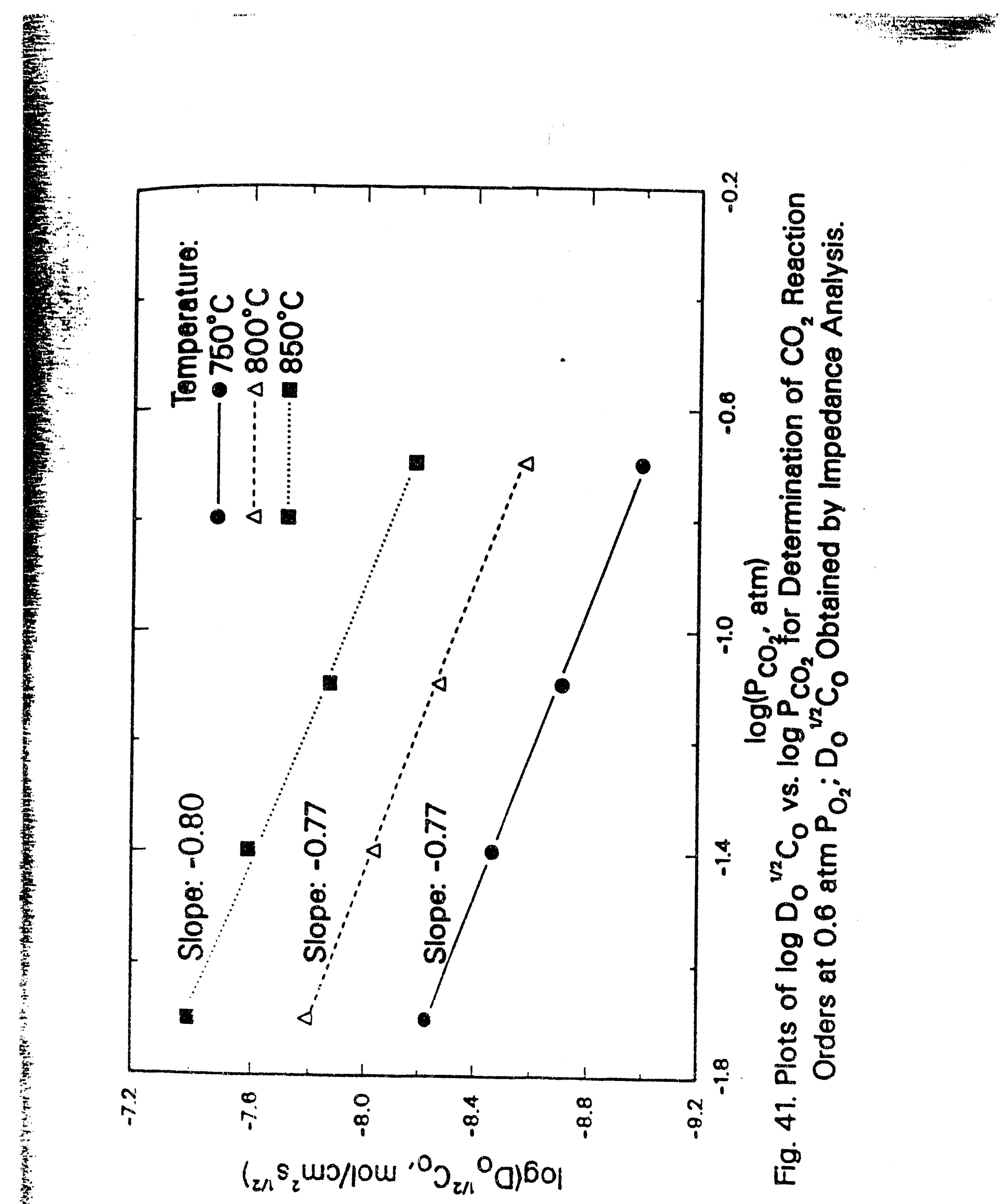
phenomenon is attributed to the local accumulation of the unneutralized oxide ions which shifts the reversible electrode potential in negative direction (9i). The effects of $\mathrm{PCO}_{2}$ on the peak current density $\left(i_{p}\right)$ vs. square root of the scan rate $\left(v^{1 / 2}\right)$ plot at 750,800 , and $850^{\circ} \mathrm{C}$ are shown in Figs. 46, 47, and 48 . A linear behavior of $i_{p}$ ws. $v^{1 / 2}$ and invariance of $E_{p}$ with respect to the scan rate indicate that oxygen reduction in $\mathrm{Li}_{2} \mathrm{CO}_{3}$ melt is "reversible" up to $200 \mathrm{mV} / \mathrm{s}(79)$. An increase in partial pressure of carbon dioxide decreases the slope of $i_{p}$ vs. $v^{1 / 2}$ plot, because the slope is directly proportional to $D_{O}^{1 / 2} C_{O}$, where $D_{O}$ is the diffusion coefficient and $C_{0}$ is the bulk concentration of the diffusion limiting reactant species, peroxide ions. Appleby and Nicholson (45) auggested that the diffusion-controlled peali for $\mathrm{O}_{2}$ reduction in $\mathrm{Li}_{2} \mathrm{CO}_{3}$ can be described by the theory developed by Berzins and Delahay (76) for inc reversible diffusion controlled peak where the product activity is considered to w' invariant and equal to unity (e.g., metal deposition). According to Berzins and Ilelahay: the peak current density is given by the following expression:

$$
i_{p}=0.61 \frac{(\mathrm{nF})^{3 / 2}}{(\mathrm{RT})^{1 / 2}} \mathrm{C}_{O} \mathrm{D}_{O}^{1 / 2} \mathrm{v}^{1 / 2}
$$

The transport parameter. $D_{O}^{1 / 2} C_{O}$, was calculated from the slope of $i_{n}$ vs. $r^{1 / 2}$ plot using Eqn. [104]. As shown in Table 4. the calculated values of the transport parameter for various $\mathrm{PCO}_{2}$ and temperatures are compared with those estimated by the electrochemical impedance spectroscopy: An iricrease in partial pressure of carbor woxide decreases the product. $\mathrm{D}_{\mathrm{O}}^{1 / \mathrm{C}_{0}} \mathrm{C}_{\mathrm{O}}$. which is mainly due to the decrease in peroxide 10: concentrailot. Temperature has a significant efiect on the product. $D_{O}^{1 / 2} \mathrm{Co}$. for example al (1.02 atm partial pressure of carbon dioxide. aimost an order of magnitude Hercase $\|, \mathrm{D}_{\mathrm{C}}^{1 /} \mathrm{C}$. o was observed when temperature was increased from 750 to $850^{\circ} \mathrm{C}$. tiumere: the utivence of temperature on $\mathrm{D}_{\mathrm{O}}^{1 / 2} \mathrm{CO}$ was les significant at higher $\mathrm{P}_{\mathrm{CO}}$. The reaction orcier and apparent activation energ! for $D_{O}^{1 / 2} C_{0}$. estimated using cyclic voliammetry technique. concurrec with those abtained by impedance araly'sis. 
phenomenon is attributed to he local accumulation of the unneutralized oxide ions which shifts the reversible electrode potential in negative direction (97). The effects of $\mathrm{PCO}_{2}$ on the peak current density $\left(i_{p}\right)$ vs, square root of the scan rate $\left(v^{1 / 2}\right)$ plor at 750,800 , and $850^{\circ} \mathrm{C}$ are shown in Figs. 46, 47, and 48. A linear behavior of $i_{p}$ us. $v^{1 / 2}$ and invariance of $E_{p}$ with respect to the scan rate indicate that oxygen reduction in $\mathrm{Li}_{2} \mathrm{CO}_{3}$ melt is "reversible" up to $200 \mathrm{mV} / \mathrm{s}$ (79). An increase in partial pressure of carbon dioxide decreases the slope of $i_{p}$ is. $v^{1 / 2}$ plot, because the slope is directly proportional to $\mathrm{D}_{O}^{1 / 2} \mathrm{C}_{O}$, where $\mathrm{D}_{O}$ is the diffusion coefficient and $\mathrm{C}_{O}$ is the bulk concentration of the diffusion limiting reactant species, peroxide ions. Appleby and Nicholson (46) suggested that the diffusion-controlled peak for $\mathrm{O}_{2}$ reduction in $\mathrm{Li}_{2} \mathrm{CO}_{3}$ can be described by the theory developed by Berzins and Delahay (76) for the reversible diffusion controlled peak where the product activity is considered to be invariant and equal to unity (e.g., metal deposition). According to Berzins and Delahay, the peak current density is given by the following expression:

$$
i_{p}=0.61 \frac{(n F)^{3 / 2}}{(R T)^{1 / 2}} C_{O} D_{O}^{1 / 2} v^{1 / 2}
$$

The transport parameter, $D_{O}^{1 / 2} C_{O}$, was calculated from the slope of $i_{p}$ vs. $v^{1 / 2}$ plot using Eqn. [106]. As shown in Table 4, the calculated values of the transport parameter for various $\mathrm{PCO}_{2}$ and temperatures are compared with those estimated by. the electrochemical impedance spectroscopy. An increase in partial pressure of carbon droxide decreases the product, $\mathrm{D}_{\mathrm{O}}^{1 / 2} \mathrm{C}_{\mathrm{O}}$. which is mainly due to the decrease in peroxide 10r. concent allor. Temperature has a significant effect on the product. $\mathrm{D}_{\mathrm{O}}^{1 / 2} \mathrm{C}_{\mathrm{O}}$. jo: exiample. at 0.02 atm partial pressure of carbon dioxide. almost an oroier of magnitude macrass in. $D_{C}^{1} C_{O}$ was observed when temperature was increased from 750 to $850^{\circ} \mathrm{C}$. Huweves. the infiuence of temperature on $D_{O}^{1 / 2} \mathrm{C}_{\mathrm{O}}$ was less significant at higher $\mathrm{P}_{\mathrm{CO}}$. Tue reaciion order and apparent activation energy for $\mathrm{D}_{\mathrm{O}}^{1 / 2} \mathrm{C}$ o. estimated using cyclic voltanmeiry technique concurred with those obtained by impedance analysis. 


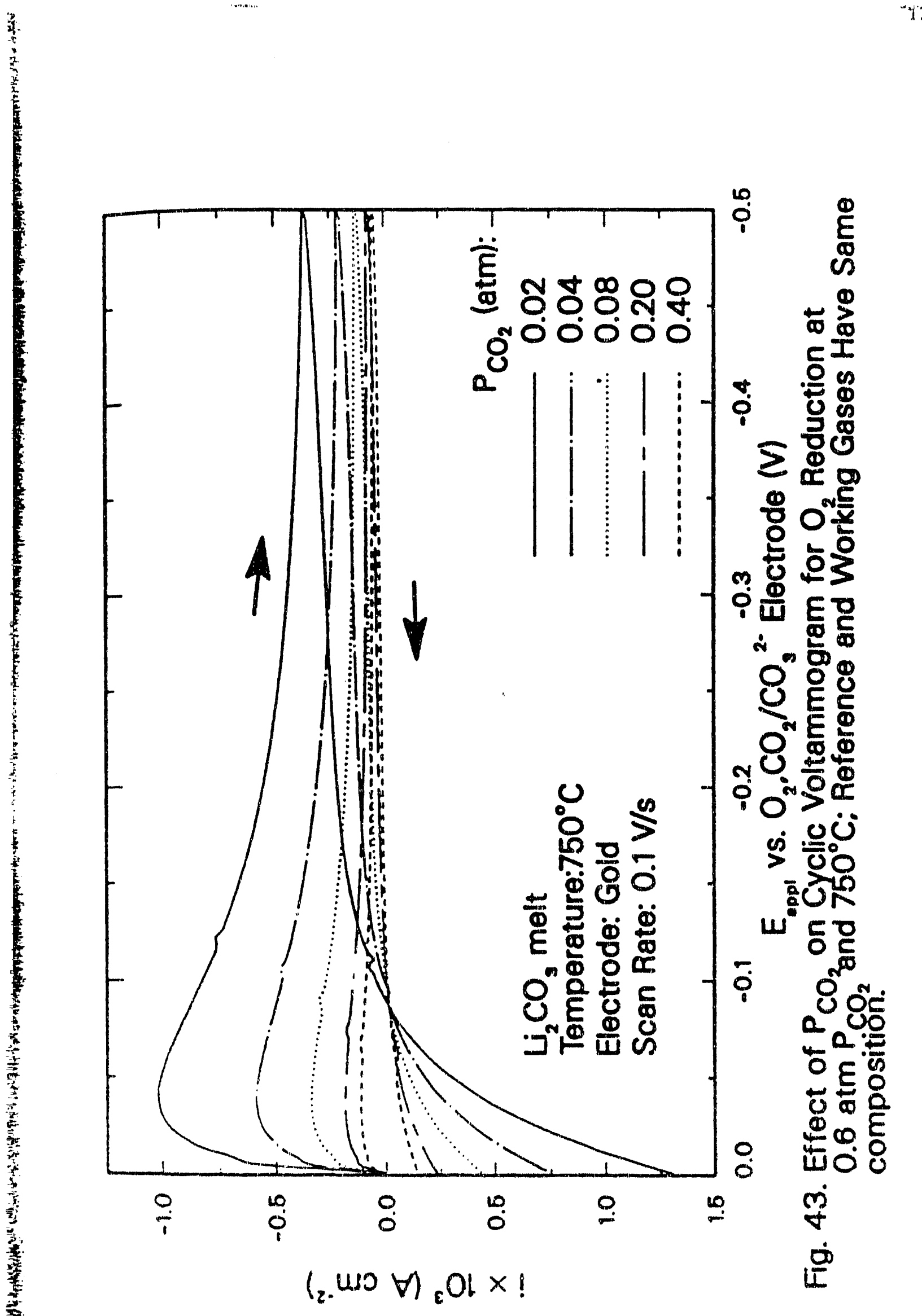


$\stackrel{\circ}{\circ}$

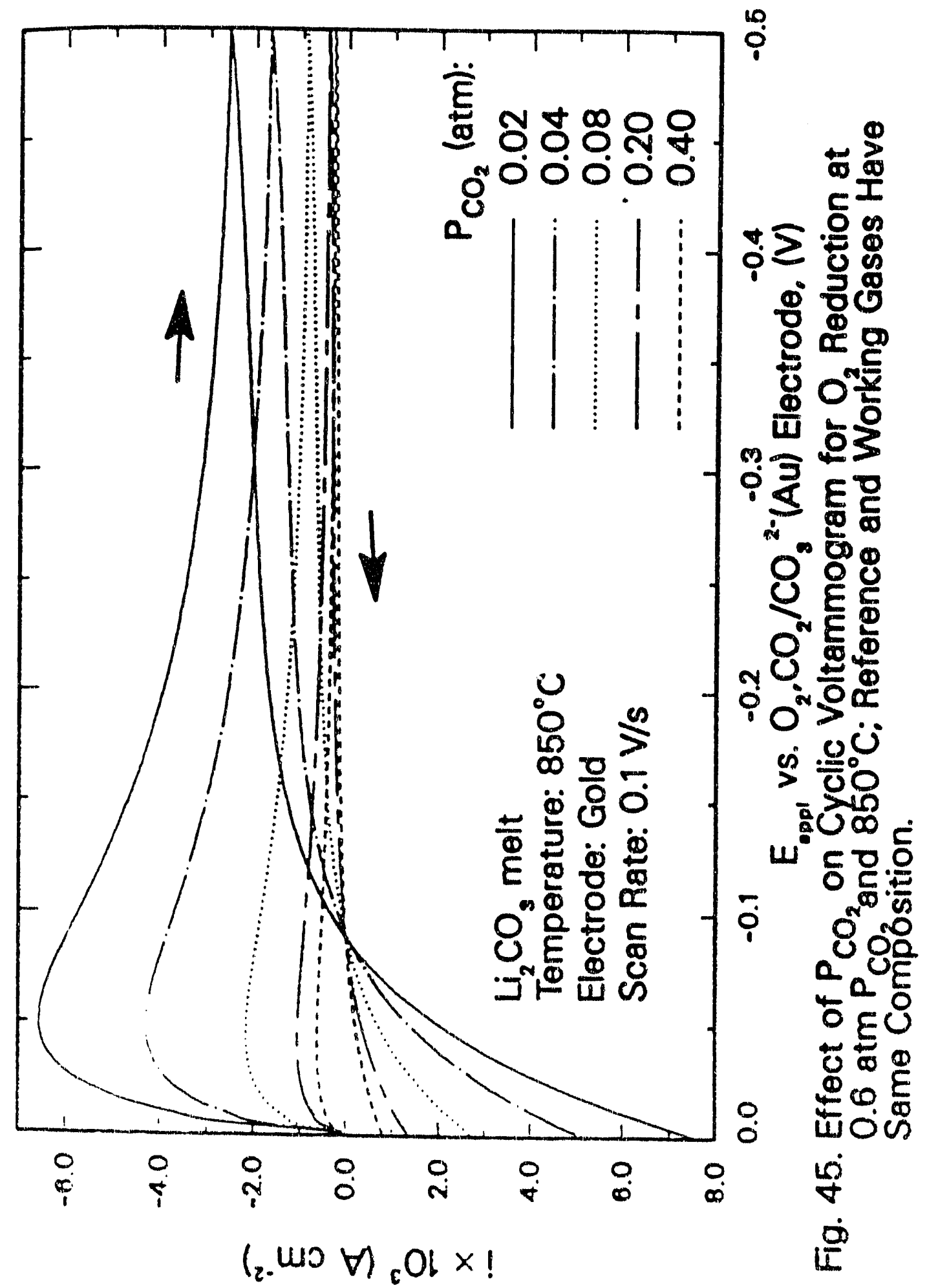
ه००0 


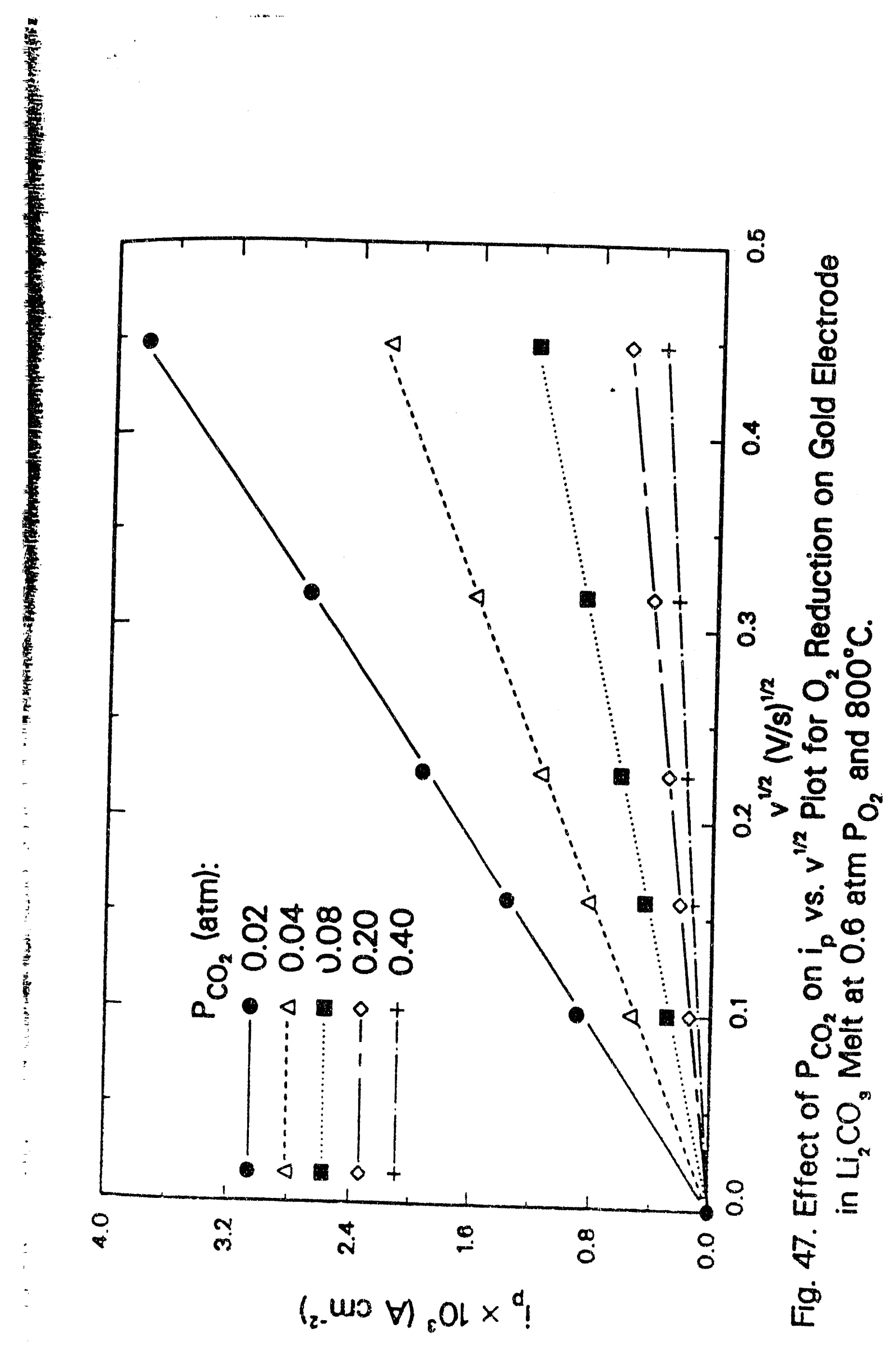




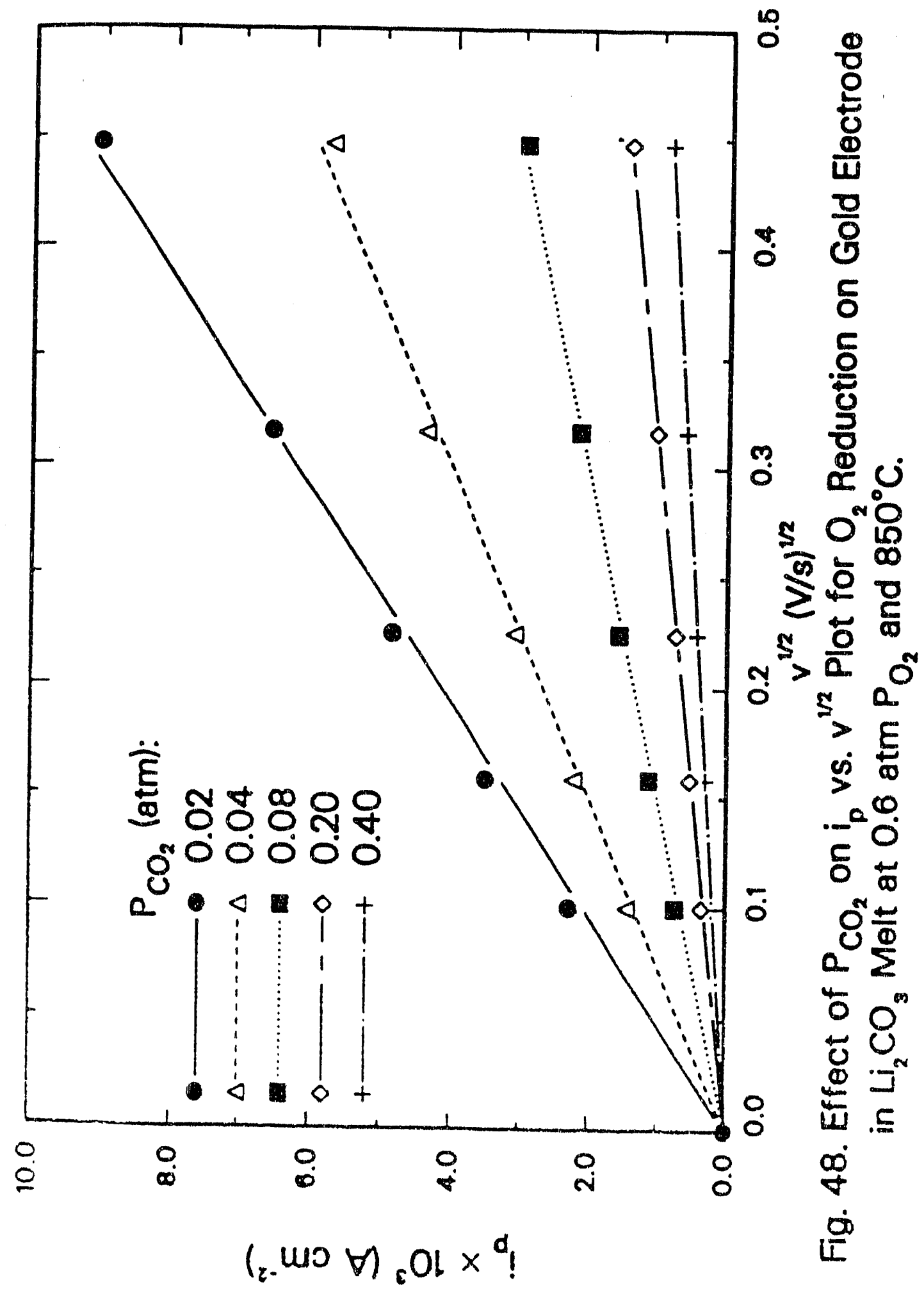




\section{Conclusions}

The kinetic and mass transfer related parameters for the oxygen reduction in pure $\mathrm{Li}_{2} \mathrm{CO}_{3}$ were determined as a function of $\mathrm{P}_{\mathrm{CO}_{2}}$ and temperature by electrochemical impedance spectroscopy and cyclic voltammetry. The impedance spectra were analyzed by the Randles-Ershler equivalent circuit model using a complex nonlinear least square parameter estimation technique. The impedance data analy'sis yielded the electrode kinetic and mass transfer parameters such the charge transfer resistance, Warburg coefficient, double layer capacitance, and uncompensated solution resistance. The influence of carbon dioxide on the Warburg coefficient was examined and its reaction order was estimated to be about -0.8 , which is consistent with the theoretical value of -1.0 for the formation of peroxide species (Eqn. [96]). The values for $\mathrm{D}_{\mathrm{O}}^{1 / 2} \mathrm{C}_{\mathrm{O}}$ obtained by impedance analysis and by cyclic voltammetry agree well. The decrease in the exchange current density with increase in partial pressure of carbon dioxide is due to the decrease in the concentration of peroxide ions with an increase in the partial pressure of carbon dioxide (Eqn. [96]). The carbon dioxide reaction order for the exchange current density was determined to be -0.52 . This value does not agree with the predicted theoretical reaction order of -1.25 when whe first charge transfer step (Eqn. [97]) is rate determining. This inconsistency in the reaction order may be due to slow neutralization kinetics (Eqn. [99]). since the rartial pressure of carbon dioxide was as low as 0.02 atm. The activation energy for the exchange current density was determined to be about $132 \mathrm{~kJ} / \mathrm{mol}$. Also. the renction order with respect to carbon dioxide and the activation energy for $\mathrm{D}_{O}^{1 / 2} \mathrm{C}_{\mathrm{O}}$

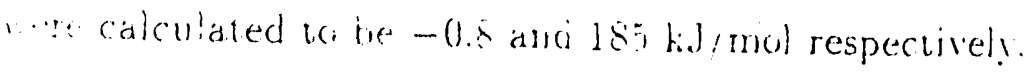

An examination of a difiusion-comirolled peati indicales that the oxygent redur.

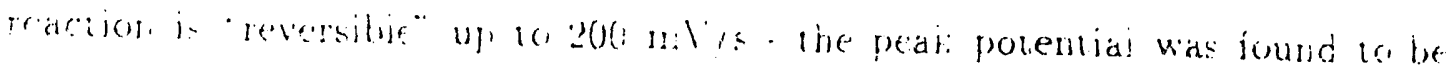

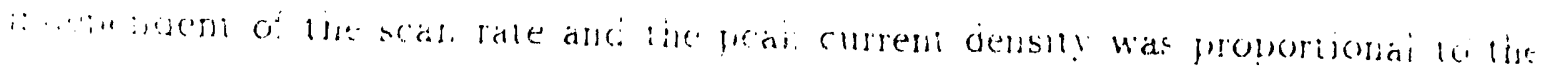

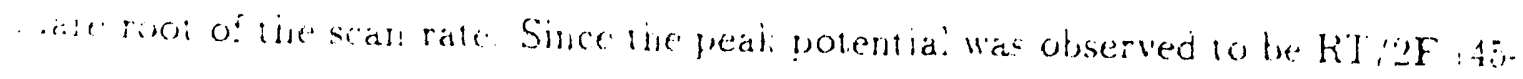

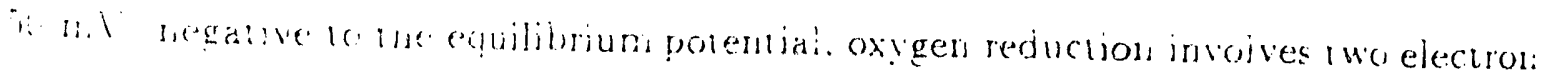

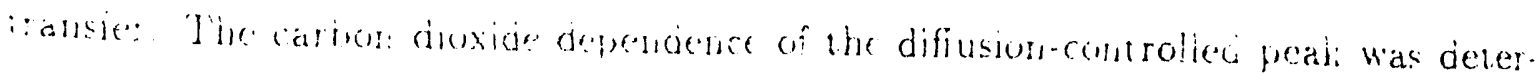

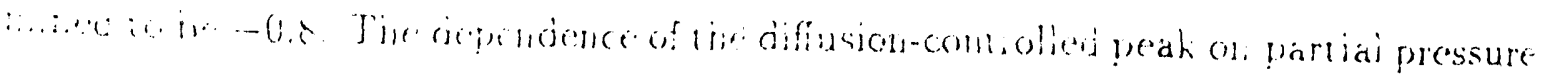


of oxy'gen was determined to be +0.5 by cyclic voltammetry and EIS techriques in the previous chapter. These results clearly indicates that the oxygen reduction reaction : on a submerged gold electrode in a pure lithium carbonate is diffusion controlled and t the peroxide is the diffusing species. The temperature dependence of the diffusion† controlled peak was also examined and the activation energy was calculated to be about $176.6 \mathrm{~kJ} \mathrm{~mol}^{-1}$; this activation energy value agrees with that obtained from EIS data. 


\section{CHAPTER VII}

\section{CONCLUSIONS AND RECOMMENDATIONS}

\section{Conclusions}

The oxygen reduction reaction on a fully-submerged gold electrode in a pure lithium carbonate was investigated to determine electrode kinetic and mass transfer parameters. The electrode kinetic and mass transfer parameters were determined using Electrochemical Impedance Spectroscopy (EIS) and cyclic voltammetry. The electrochemical impedance spectra were analyzed using the Randles-Ershler equivalent circuit model and Complex Nonlinear Least Square (CNLS) program to determine the charge transfer resistance, Warburg coefficient, double layer capacity, and uncompensated electrolyte resistance. The electrode kinetic parameters were determined as a function of temperature and partial pressures of oxygen and carbon dioxide to estimate the activation energies and the reaction orders. The estimation of the reaction orders for oxygen carbon dioxide are essential for the determination of oxygen reduction mechanism.

- The literature review indicates that oxygen electrode reaction in molten carbonate electrolyte is very complex. The physical solubility of oxygen in nolt $n$ alkali carbonate electrolyte is negligible. The chemical equilibria involving oxygen and carbon dioxide form species such as peroxide and superoxide ions which participate in the oxygen reduction mechanism. The concentrations of the peroxide and/or superoxide species depend on the cations present in the melt. temperature. and partial pressures of oxigen and carbon dioxice.

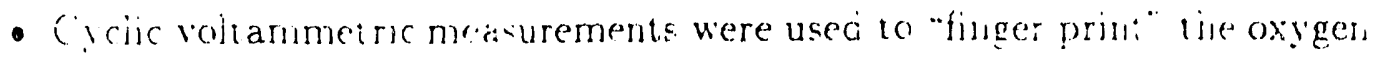
renuction reaction. Tine cyclic voltammograms showed difusion-limited peats foljowed by liming current plateaus. The uxygen reduction reaction in a pure lithium rarbonate melt is "reversible" ub $102010 \mathrm{~m}$ 'is. 
since a plot the peak current density vs, square root of the scan rate was linear and the peak potential did not change with the scan rate. Also, oxygen reduction reaction in a pure lithium carbonate melt involved two electrons because the peak potential was $\mathrm{RT} / 2 \mathrm{~F}(\sim 45 \mathrm{mV})$ negative to the equilibrium potential.

- The peak current density showed a linear behavior with respect to the square root of the scan rate and the slope of this plot is proportional to the product of the concentration $\left(\mathrm{CO}_{\mathrm{O}}\right)$ and the square root of the diffusion coefficient $\left(D_{O}\right)$ of the limiting species. The product $D_{O}^{1 / 2} C_{O}$ obtained from the cyclic voltammetric measurements agreed well with those obtained by EIS technique. The reaction orders for oxygen and carbon dioxide were determined to be +0.5 and -0.8 , respectively; these reaction orders agree with the theoretical reaction orders for formation of peroxide ions.

- The electrochemical impedance spectra indicate that electrode kinetics for oxygen reduction in a pure lithium carbonate melt are very rapid, because of the absence of semicircle in a complex plane impedance plot. The complex plane impedance plot showed a linear behavior with a slope of $45^{\circ}$ in a region of low frequency, indicating that the diffusion process is dominant. The electrochemical impedance spectra were analyzed by the complex plane plots (graphical analysis) and CNLS program based on Levenberg-Marquardt algorithm. The electrode kinetic and mass transfer parameters determined by the graphical and CNLS analyses are consistent. The CNLS method uses the entire frequency spectrum. whereas the graphica! analysis uses the impedance date in a region of jow ireguersy only. Hence. the parameters esimaied by the graphica: andresis should ue considered approximate compared in those obtained by the CNLS meinod. The parameters obtained by the CNLs lechnique no: only have befler accuracy but also provide the confidence limits fo: the estimalec paraneters 
- The product $\mathrm{D}_{\mathrm{O}}^{1 / 2} \mathrm{C}_{\mathrm{O}}$ determined from the values of the Warburg coefficient agreed well with those determined from the cyclic voltammetric measurements. The reaction orders of +0.5 and -0.8 were determined for partial pressures of oxygen and carbon dioxide, respectively. The values of the reaction orders clearly showed that the diffusing species is the peroxide ions. The apparent activation energy of the product $\mathrm{D}_{\mathrm{O}}^{1 / 2} \mathrm{C}_{\mathrm{O}}$ was estirnated to be $175 \mathrm{~kJ} / \mathrm{mol}$; this value is a function of the activation energies of the peroxide formation and the diffusion coefficient.

- The exchange current density values were obtained from the values of the charge transfer resistance. The value of $i_{0}$ was estimated to be $44 \mathrm{~mA}$ $\mathrm{cm}^{-2}$ at $750^{\circ} \mathrm{C}$ and $90 \% \mathrm{O}_{2}$ and $10 \% \mathrm{CO}_{2}$; this value agreed well with the data available in the literature. The reaction order for oxygen was determined to be 0.3-0.4 indicating that the first charge transfer step for the peroxide path may be the rate determining step. The reaction order for carbon dioxide was determined to be -0.5 . The apparent activation energy for the exchange current density was estimated to be about 110 $\mathrm{kJ} / \mathrm{mol}$ : this value of the apparent activation energy agree with that cited in the literature for the $(\mathrm{Li}, \mathrm{K})_{2} \mathrm{CO}_{3}$ eutectic melt in a region of high temperature.

- The double layer capacitance value increased with a decrease in partial pressure of carbon dioxide and an increase in temperature and partia! pressure of oxygen. This behavior indicated formation of an oxide laver on the gold electrode. The uncompensated electrolyte resistance did no: show a dependence on temperature. $\mathrm{P}_{\mathrm{O}_{2}}$. or $\mathrm{P}_{\mathrm{CO}_{2}}$.

f.rcommendations

- Appiicalor of the EIS technique to study oxygen reduction hinei. irs in oiver mels such as $\mathrm{Na}_{2} \mathrm{CO}_{3}$. (Li. $\mathrm{Na}_{2} \mathrm{CO}_{3}$. (LiK) $\left.{ }_{2} \mathrm{CO}\right)_{3}$ and (Li. $\mathrm{Na} \cdot \mathrm{K}$ ), $\mathrm{CO}_{3}$ for the following objectives: (i) to elucidate oxvgen re. duction mechanism in other melts. for example. in a poiassium-ricl meli 
the superoxide species may play an important role; (ii) to establish the data base for electrode kinetic and mass transfer parameters; (iii) to determine the effects of additives which are known to promote formation of peroxide/superoxide and/or to suppress the cathode dissolution; and (iv) ultimately, to determine the optimum composition of the electrolyte for the molten carbonaie fuel cell.

- Development of a mathematical model based on the phenomenological equations to describe electrochemical impedance spectra for oxygen reduction reaction in molten alkali carbonate electrolytes. The kinetic model should not include an assumption of a single rate determining step.

- The double layer capacitance at a gold electrode in a pure lithium carbonate has a high value and shows a strong dependence on temperature. $\mathrm{P}_{\mathrm{O}_{2}}$, and $\mathrm{P}_{\mathrm{CO}_{2}}$. This behavior requires further investigation. 


\section{LIST OF SYMBOLS}

a

$\mathrm{a}^{2-}$

${ }^{a} \mathrm{CO}_{3}^{2--}$

A

b

$C_{\mathrm{dl}}$

$\mathrm{C}_{\mathrm{j}}$

$D_{j}$

E

$E^{\circ}$

Eappl

$\mathrm{F}$

f

i

$i_{c}$

if

$i_{0}$

$i_{0}^{c}$

$i_{r}$

$K_{d}$

i.

$x$

10.

!n.

$\therefore$

1.

reaction order for oxygen

activity of oxide

activity of carbonate

electrode area, $\mathrm{cm}^{2}$

reaction order for carbon dioxide

double layer capacitance, $\mu \mathrm{F} / \mathrm{cm}^{2}$

bulk concentration of species $j, \mathrm{~mol} / \mathrm{cm}^{3}$

bulk diffusion coefficient of species $j, \mathrm{~cm}^{2} / \mathrm{s}$

electrode patential, $\mathrm{V}$

standard electrode potential, $\mathrm{V}$

applied electrode potential, $\mathrm{V}$

Faraday's constant, 96,487 C/equiv.

objective function for minimization, $\Omega \mathrm{cm}^{2}$

current density, $\mathrm{A} / \mathrm{cm}^{2}$

charging current density, $\mathrm{A} / \mathrm{cm}^{2}$

faradaic current density, $\mathrm{A} / \mathrm{cm}^{2}$

exchange current density, $A / \mathrm{cm}^{2}$

kinetic parameter, $\mathrm{A} / \mathrm{cm}^{2}$

peak current density, $\mathrm{A} / \mathrm{cm}^{2}$

dissociation constant. atm

number of electrons transferred in electrode reaction

lotal number of observation

partial pressure of axygen

partial pressure of carbon dioxide

umversa gat consiant. $8.3143 \mathrm{~J} \mathrm{~mol}^{-1} \mathrm{~K}^{-2}$

cunge trausier resistance. $\Omega \mathrm{cm}^{2}$

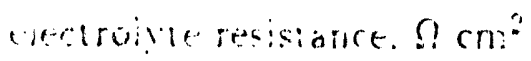

icmperature l: 
I elecctrode potential relative to given reierence electrode

placed just outside double layer, $V$

$\hat{\imath}$

sinusoidal potential perturbation, $V$

$|\bar{V}|$ amplitude of the potential perturbation, $\mathrm{V}$

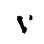

scan rate, $\mathrm{V} / \mathrm{s}$

'

weighting factor

$\mathrm{X}$

vector of model parameters

$Y_{\text {el }} \quad$ interfacial admittance, $\Omega^{-1} \mathrm{~cm}^{-2}$

$2 \quad$ impedance, $\Omega \mathrm{cm}^{2}$

|Z| modulus of impedance, $\Omega \mathrm{cm}^{2}$

$z_{i} \quad$ charge number of species $i$

$\mathrm{Z}_{W^{\prime}} \quad$ complex Warburg impedance, $\Omega \mathrm{cm}^{2}$

Greek letters

$a_{6} \quad$ anodic transfer coefficient

$a_{c} \quad$ cathodic transfer coefficient

3 symmetry factor for elecctrochemical reaction

$\lambda$ dummy variable

$\sigma \quad$ Warburg coefficient, $\Omega \mathrm{cm}^{2} \mathrm{~s}^{-1 / 2}$

$\Phi$ current function

c phase angle

Superscripts

real part

iniaginary part

iusiscrimt:

lik measurement poin:

ieroxide o: superoxice ions

cartionats ins 


\section{REFERENCES}

1 A. J. Appleby and F. R. Foulkes, "Fuel Cell Handbook," Van Nostrand Reinhold, New York, NY, (1989).

2 W. R. Grove, Phil. Mag., 14, 127, (1839).

3 i. Mond and C. Langer, Proc. Roy. Soc., 46, 296, (1889).

4 F. T. Bacon, Beama J., 61, 6, (1954).

5 E. Baur, W. D. Treadwell, and G. Trumpler, Z. Elektrochem., 27, 199, (1921).

6 J. A. A. Ketelaar and G. H. J. Broers, Ind. Eng. Chem., 52, 303, (1960).

7 G. H. J. Broers, Ph. D. Dissertation, University of Amsterdam, Amsterdam, The Netherlands, (1958).

$\delta$ E. Gorin and H. L. Recht, Chem. Eng. Progr., 55, 51, (1959).

9 E. Gorin and H. L. Recht. Ind. Eng. Chem., 52, 306, (1960).

10 H. H. Chambers and A. D. S. Trantram, Ind. Eng. Chem., 52, 295, (1960).

11 H. H. Chambers and A. D. S. Trantram, in "Fuel Cells, ${ }^{n}$ G. J. Young, Editor. p. 94. Reinhold, New York, (1960).

12 K. Kinoshita, F. R. McLarnon, and E. J. Cairns, "Fuel Cells: A Handbook," DOE/METC-88/6096. L.S. Dept. of Energy, Morgantown, WV (1988).

13 J. R. Selman. Energu. 11. 153. (1986).

14 R. Brrnarc. "Sth Workshop on Molten Carbonate Fuel Cells." EPRI/DOE worisnof. Morganowt. MV. (1987).

1: A Mnonc. ( ) Jur. anci H. C. Maru. "Optimization of Molten Carbonate Fu Cel. Eiectuvlyce" Vaiona! Fuel Celi Seminar Abstracts. 1.193 (1985.

ii I : Konds. M H Jiawe. A. W. Schnake and L. W. Spradir. "Fuel Cell

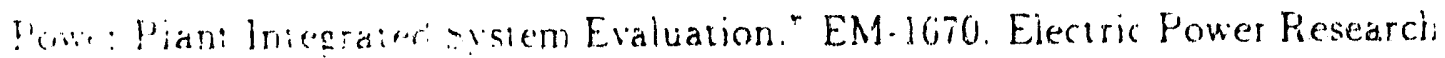

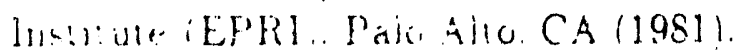


17 J. Brown. B. Nazar, and V. Varwa, "Site-Specific Assessment of a $511 \mathrm{Ml}$ " Coal Gasification Air-Cooled Fuel Cell Power Plant, ${ }^{\circ}$ RP1091-11. Electric Power Research Institute (EPRI), Palo Alto, CA (1983).

18 DOE/METC-87/0257, "Fuel Cells Technology Status Reports", (1986).

19 H. Ide, T. Yoshida, H. Ueda, and N. Horiuchi, 24th Intersociety Energy Con. version Engineering Conference Proceedings, vol. 3, 1517, (1989).

20 P. G. P. Ang and A. F. Sammells, J. Electrochem. Soc., 127, 1287, (1980).

21 "Fuel Cell Research on Second-Generation Molten Carbonate Systems," J'roject 8984. Quarterly and Final Status Reports, July 1, 1976-Sept. 30, 197i, Vol. 2. IGT, Chicago, IL, (1977).

22 B. Kr. Andersen, $\mathrm{Ph}$. D. Dissertation, The Technical University of Demmark, Lyngby, Denmark, (1975).

23 S. H. Lu, Ph. D. Dissertation, Illinois Institute of Technology, Chicagu, Il, (1985).

24 E. J. King. "Qualitative Analysis and Electrolytic Solutions," Harcourt, Brare \&: World, Inc., New York (1959), p. 242.

25 H. Lux, Z. Elektrochem., 45, 303, (1939).

26 H. Flood and T. Forland, Acta Chem. Scand., 1, 781. (1947).

27 E. Baur and R. Brunner, Z. Elektrochem., 41, 794, (1935).

28 G. J. Janz, F. Colom, and F. Saegusa, J. Electrochem. Soc.. 107. 581. (1960).

24 A. M. Trunov and G. K. Stepanor. Akad. Nauk SSSR liral. Fil. Prue Iust. Elcitokhim.. 3. 64. (1962).

3i. (i. . Jarza and I. Soegusa. Electrochrm. Acto. 7. 393. 1196i2..

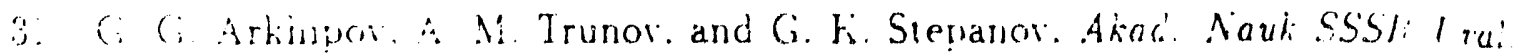

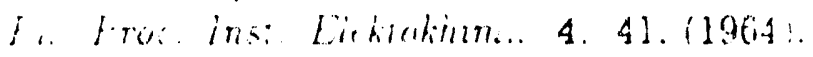

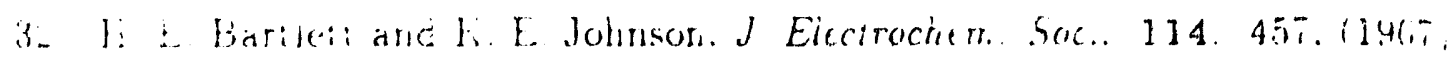

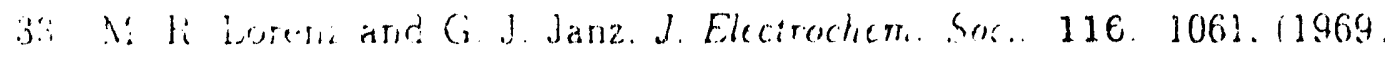


34 G. K. Stepanor and A. M. Trunor. Akad. Aauk. SSSR liral. Fil. Proc. Inst. Elektrokhim, 2. 9T, (1961).

35 G. K. Stepanor and A. M. Trunor, Tr. 6, Ural'sk fil. Akad. Nauk. (USSR). $3,73,(1965)$.

36 H. Flood, T. Forland, and K. Motzfeldt, Acta Chim. Scand., 6, 257, (1952).

37 J. J. Scheer, A. E. van Arkel, and R. D. Heyding, Can. J. Chem., 33, 683, (1955).

38 N. Busson, S. Palous, R. Buvet, and J. Millet, C. R. Acad. Sc. Paris, 260, 6097, (1965).

39 N. Busson, S. Palous, R. Buvet, and J. Millet, C. R. Acad. Sc. Paris, 261, $720,(1965)$.

40 N. Busson, S. Palous, J. Millet, and R. Buvet, Electrochim. Acta, 12, 1609, (1967).

41 A. Z. Borucka. Electrochim. Acta, 13, 295, (1968).

42 A. Z. Borucka, in "Fuel Cell Systems, Vol. II, Advan. Chem. Ser., 90," B. Baker, Editor, p. 242, American Chemical Society, Washington D. C., (1969).

43 A. Borucka and C. M. Sugiyama, Electrochim. Acta, 13, 1887, (1968).

44 A. Borucka and C. M. Sugiyama, Electrochim. Acta, 14, 871, (1969).

45 A. J. Appleby and S. B. Nicholson, J. Electroanal. Chem., 38. App. 14, (1972).

40 A. J. Appleby and S. B. Nicholson, ibid., 53. 105. (1974).

4: A. J. Appleby and S. B. Nicholson. ibid.. 83. 309. (197i).

4: A. A Appleby and S. B. Nicholson. ibid. 112. ii. $11950 \mathrm{i}$.

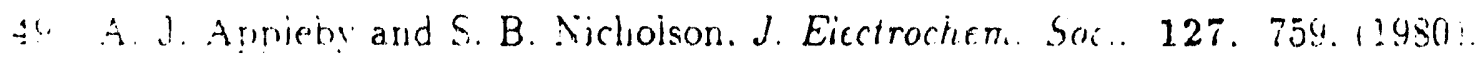

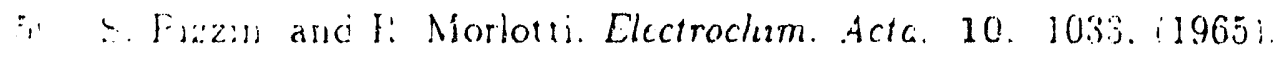

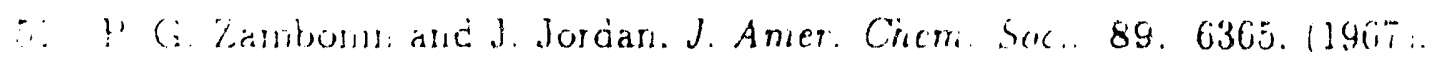

5: X. S Mrench and D. Inmar. J. Electroanal. Chemi. 17. 319. 11968: 
53 G. B. Dunks and D. Sielinan, Inorg. Chem., 22, 2168, (1983).

54 T. E. Tang, J. R. Selman, T. D. Claar. and L. g. Marianwoski, Abstract 127, p.348. The Electrochemical Society Extended Abstracts, Vol. 80-2, Hollywood, FL, Oct. 5-10, (1980).

55 J. Winnick and P. N. Ross, J. Electrochem. Soc., 128, 991, (1981).

56 A. J. Appleby and C. Van Drunen, J. Electrochem. Soc., 127, 1655, (1980).

57 W. M. Vogel, S. W. Smith, and L. J. Bregoli, J. Electrochem. Soc., 130, 575, (1983).

$5 \delta$ S. W. Smith, W. M. Vogel, and S. Kapelner, J. Electrochem. Soc., 129, 1668, (1982).

59 S. H. White and U. M. Twardoch, Electrochim. Acta, 27, 1599, (1982).

60 C. Y'. Yuh, Ph. D. Dissertation, Illinois Institute of Technology, Chicago, IL, (1985).

61 1. Uchida, T. Nishina, Y. Mugikura and K. Itaya, J. Electroanal. Chem., 206, $229,(1986)$.

62 1. Uchida, Y'. Mugikura, T. Nishina and K. Itaya. ibid., 206, 241, (1986).

63 I. Uchida, T. Nishina, Y'. Mugikura and K. Itaya, ibid., 209, 125, (1986).

64 P. K. Adanuvor. R. E. White, and A. J. Appleby. J. Electrochem. Soc., 137. 2095, (1990).

65 K. Ramaswami, Ph. D. Dissertation, Illinois Institute of Technology, Chicago. IL, (1990).

66. T. Nishina and 1. Lichida. Molten Carbonate Fuel Cells. J. R. Selman. I. Lichida. and D. A. Shores. Editors. p. 438. the Electrochemical Society Proceedings Vol. 9(1-16. Princetor. $\mathrm{NJ},(1990)$.

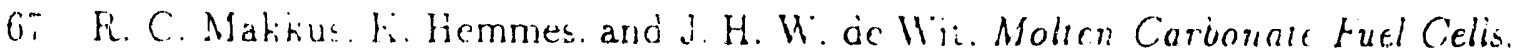

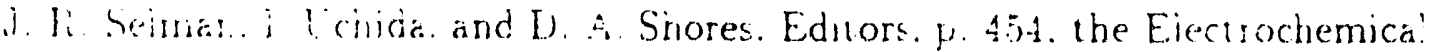

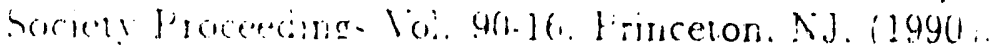

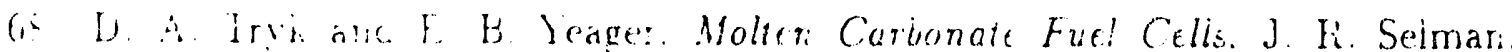

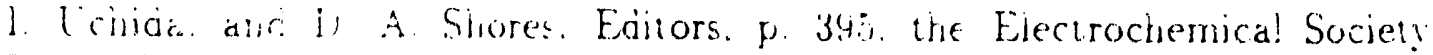

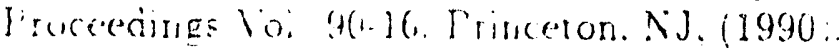


69 G. J. Janz, "Molten Salts Handbook." Academic Press, New York (1967). 70 A. V. Silakov, G. S. Tyurikov, and N. P. Vasilistor, Soviet Electrochem.. 1.
$541,(1965)$.

71 P. K. Lorenz and G. J. Janz, Electrochem. Soc., 118, 1550, (1971).

72 T. Nishina, M. Takahashi, and I. Uchida, ibid., 137, 1112, (1990).

73 S. H. White and U. M. Twardoch, ibid., 135, 893, (1988).

74 A. Borucka, J. Electrochem. Soc., 124, 972, (1971).

75 A. J. Bard and L. R. Faulkner, "Electrochemical Methods," John Wiley and Sons, New York (1980), p. 221.

76 T. Berzins and P. Delahay, J. Amer. Chem. Soc., 75, 555, (1953).

77 W. L. Miller and A. R. Gordon, J. Phys. Chem., 35, 2785, (1931).

78 P. Delahay: "New Instrumental Methods in Electrochemistry," John Wiley Interscience Publishers, Inc., New York (1954), p. 122.

79 R. S. Nicholson and I. Shain, J. Amer. Chem. Soc., 36, 706, (1964).

80 M. Sluyters-Rehbach and J. H. Sluyters, in "Electroanalytical Chemistry," Vol. 4. A. J. Bard, Editor, p. 1, Marcel Dekker, New York, (1970).

81 M. Sluyters-Rehbach and J. H. Sluyters, in "Comprehensive Treatise of electrochemistry," Vol. 9. E. l'eager, J. O'M. Bockris, and B. E. Conway. Editors. p. 177, Plenum Press, New York, (1984).

82 D. D. Macdonald and M. C. H. Mckubre, in "Modern Aspects of Electrochem. istry." Vol. 14. J. O'M. Bockris. B. E. Conway. and R. E. White. Editors. p. 61, Plenum Press. New York. (1982).

8.3 J. E. B Randies. Discuss. Faraday Soc.. 1. 11. 119471.

B B Ersher ibid.. 1. 269. (194i).

$\therefore$ (. Ciabrieli: "Identification of Electrochemica! I'roseses by Freouency lie. spome Analysis." Solariron lnstruments. Farnborougi. Engiarad. 1998

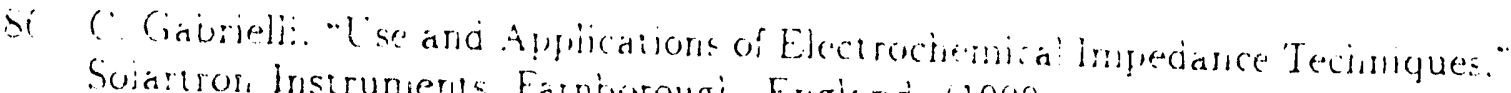

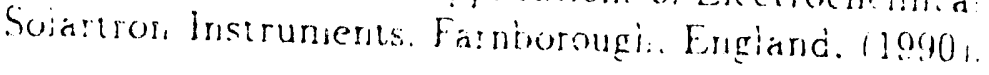


Si R. De Levije and L. Pospisil. J. Electroanal

88 E. Warburg, Ann. Phys. Chem., 67, 493. $1^{\prime \prime \prime 1 . ~}$

89 J. R. Macdonald, J. Electroanal. Chem., 2\%" ¿i, (1987).

90 J. R. Macdonald, in "Impedance Spectrosı"l ' Emphasizing Solid Materials and Systems," J. R. Macdonald, Editor, p. 1 1.hin Wiley \& Sons, New York, (1987).

91 J. R. Macdonald, Electrochim. Acta, 35, f A I (1990).

92 K. Levenberg, Quarterly of Appl. Math., 2. III. (1944).

93 D. W. Marquardt, J. Soc. Ind. Appl. Math, 11 431, (1963).

94 J. R. Macdonald and L. D. Potter, Jr., Solid "wılt lonics, 23, 61, (1987).

95 B. B. Dave, R. E. White, S. Srinivasan, anıl a J. Appleby, J. Electrochem. Soc., 138, 673, (1991).

96 O. Levenspiel, "Chemical Reaction Engineer."'" " p. 32, John Wiley \& Sons, Inc., New York (1972).

97 S. H. Lu and J. R. Selman, J. Electrochem. 4, 137, 1125, (1990).

98 R. De Levie and L. Pospisil, J. Electroanal. I\%, 1... 22, 277, (1969).

99 B. B. Dave, R. E. White, S. Srinivasan, and A I Appleby, "Impedance Analysis for Oxygen Reduction in a Lithium Carborin" lilectrolyte. submitted to $\mathrm{J}$. Electrochem. Soc., (1990).

\section{Supplementary Sources 1 ,.ısulted}

3 J. S. Newmar. "Electrochemical Systems." r.untice Hall. Inc.. Englewood Cliffs. N.l (1973) p. 172.

¿K. J. Vente: Electrochemical hinencs 7 . . Mical and Experinenta! As. pecis." Academic P'ress. New lork $1196 i 1$. "

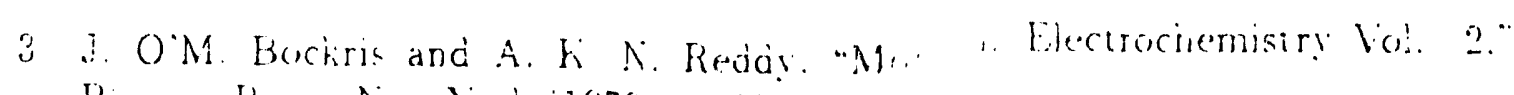
Pienum Fress New York i 1970 \% p. 99 : 


\section{APPENDIX A}

\section{DERIVATION OF ELECTRODE KINETIC EXPRESSIONS}

The electrode kinetic expressions, which include theoretical reaction orders and transfer coefficients for oxygen reduction in molten alkali carbonate electrolytes, are derived for different reaction mechanisms. The reaction mechanisms consider the oxyanions such as peroxide (46), superoxide (4i, 48), and percarbonate (53) ions. As shown below for the peroxide mechanism. each reaction mechanism is assumed to proceed by a sequence of elementary steps.

\section{Peroxide Path}

$$
\begin{aligned}
1 / 2 \mathrm{O}_{2}+\mathrm{CO}_{3}^{2-} & =\mathrm{O}_{2}^{2-}+\mathrm{CO}_{2} \\
\mathrm{O}_{2}^{2-}+\mathrm{e}^{-} & =\left(\mathrm{O}^{-}\right)+\mathrm{O}^{2-} \\
\left(\mathrm{O}^{-}\right)+\mathrm{CO}_{2}+\mathrm{e}^{-} & =\mathrm{CO}_{3}^{2-} \\
\mathrm{O}^{2-}+\mathrm{CO}_{2} & =\mathrm{CO}_{3}^{2-}
\end{aligned}
$$

()verall Reaction

$$
1 / 2 \mathrm{O}_{2}+\mathrm{CO}_{2}+2 e^{-}=\mathrm{CO}_{3}^{2-}
$$

Where $\left(\mathrm{O}^{-}\right)$is a transient species.

The ejecircie kinetic expressions are derived with the following assumptions 16.4: (i) ont: one o: the elememan steps is considered to be the rate determining

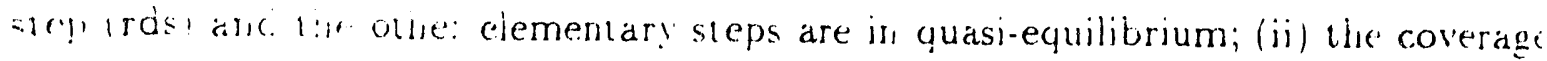

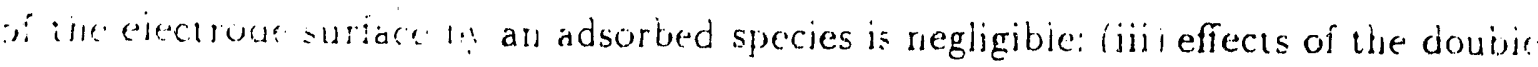

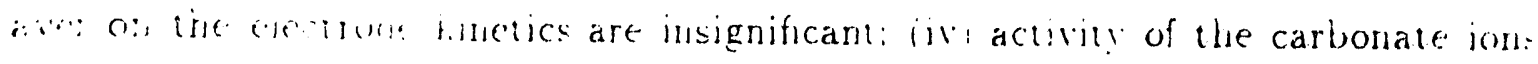

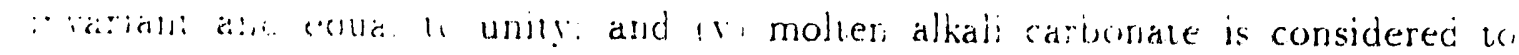

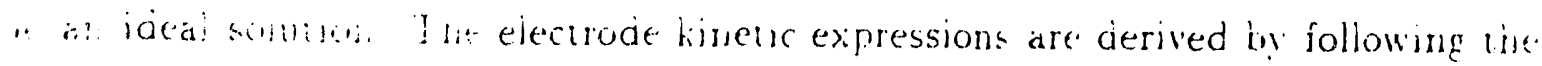

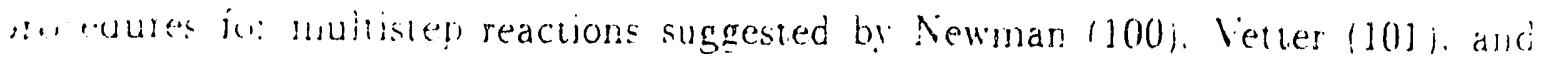


Bockris and Reddy (1012). According to Newman (100), an elementary step can be represented by the general equation

$$
\sum_{i} s_{j} M_{i}^{z_{1}}=n e^{-}
$$

where, $\mathrm{n}$ is the number of electrons transferred and $\mathrm{z}_{\mathrm{i}}$ is the charge number of species i. The kinctic expression for the elementary step is given by the following expression:

$$
\begin{aligned}
r= & \frac{i}{n F} \\
= & k_{a} \exp \left[\frac{(1-\beta) n F}{R T} v\right] \prod_{i} C_{i}^{p_{1}} \\
& -k_{c} \exp \left[\frac{-\beta n F}{R T} V\right] \prod_{i} C_{i}^{q_{1}}
\end{aligned}
$$

where, $\beta$ is a symmmetry factor, $V$ is the difference in potential between that of the electrode and the solution just outside the double layer, $k_{\mathrm{a}}$ and $k_{\mathrm{c}}$ are the rate constants, and $\mathrm{p}_{\mathrm{i}}$ and $\mathrm{q}_{\mathrm{i}}$ are the reaction orders in the anodic and cathodic directions. respectively. For the elementary step which does not involve charge transfer. $\mathrm{n}$ is zero. ot herwise it is unity since multiple electron transfers are improbable in an elementary. step. The rate expressions for the elementary steps of the peroxide mechanism are given below:

$$
\begin{aligned}
& r_{1}=k_{a 1} C_{\mathrm{O}_{2}^{2}} P_{\mathrm{CO}_{2}}-k_{\mathrm{c} 3} \mathrm{P}_{\mathrm{O}_{2}}^{1 / 2} \\
& r_{2}=\frac{i_{2}}{\bar{F}} \\
& =k_{a_{2}} C_{(O-1}, C_{O^{\prime}-} \exp \left[\frac{\left(1-\beta_{2}\right) F}{\left.R^{\prime}\right]} V^{\prime}\right]-k_{c_{2}} C_{O}:-\exp \left[\frac{-B_{2} F}{R T} V^{\prime}\right] \\
& r_{:}=\frac{i: 3}{\bar{F}}
\end{aligned}
$$

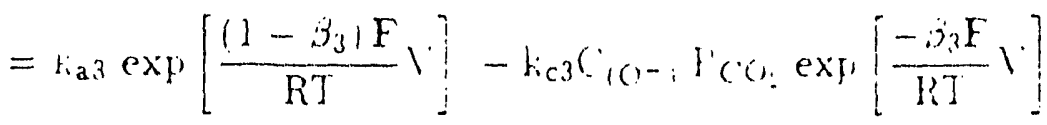

$$
\begin{aligned}
& i_{i}=i_{a i}-i_{c 4}\left(i_{C}-P_{C(1)}\right.
\end{aligned}
$$

Wiri, the assumpuion that the rates of the ciementary steps ci a simple reaction are aiways propormonal to one another. total currem dessity is expressed as the follow:

$$
=i_{1}-i_{i}=2 i=2
$$


The curren density can also be given by the Eutler-Volmer equation as function of the surface overpotential and the composition at the electrode surface:

$$
i=i_{0}\left[\exp \left(\frac{a_{a} F}{R^{\prime} T} \eta_{s}\right)-\exp \left(\frac{a_{c} F}{R T} \eta_{s}\right)\right]
$$

where, $a_{a}$ and $a_{c}$ are the anodic and the cathodic transfer coefficients, respectively, and surface overpotential is

$$
\eta_{\mathrm{s}}=\mathrm{V}-\mathrm{V}_{0} \cdot
$$

Rate Determining Step : Eqn. [106]

The steps represented by Eqns. [105], [107], and [108] are in equilibrium, hence $\mathrm{r}_{1}, \mathrm{r}_{3}$, and $\mathrm{r}_{4}$ are equated to zero to obtain expressions for $\mathrm{C}_{\mathrm{O}_{2}^{2-}}, \mathrm{C}_{\left(\mathrm{O}^{-}\right)}$, and $\mathrm{C}_{\mathrm{O}^{2-}}$, respectively:

$$
\begin{aligned}
& \mathrm{C}_{\mathrm{O}_{1-}^{2-}}=\mathrm{K}_{1} \mathrm{P}_{\mathrm{O}_{2}}^{1 / 2} \mathrm{P}_{\mathrm{CO}}^{-1} \\
& \mathrm{C}_{\left\{\mathrm{O}^{-1}\right.}=\frac{1}{\mathrm{~K}_{3}} \mathrm{P}_{\mathrm{CO}_{2}}^{-1} \exp \left[\frac{\mathrm{F}}{\mathrm{RT}} \mathrm{V}\right] \\
& \mathrm{C}_{\mathrm{O}^{2-}}=\frac{1}{\mathrm{~K}_{4}} \mathrm{P}_{\mathrm{CO}_{2}}^{-1}
\end{aligned}
$$

where.

$$
K_{i}=\frac{k_{c i}}{k_{a j}}
$$

Substituting Eqns. [119]-[121]. and [116] into Eqn. [113] to get

$$
\frac{i}{2 \mathrm{~F}}=\frac{k_{\mathrm{a}}}{K_{3} K_{4}} \mathrm{P}_{\mathrm{CO}_{2}}^{-2} \exp \left[\frac{\left(2-\beta_{2}\right) \mathrm{F}}{\mathrm{RT}} \mathrm{V}\right]-k_{\mathrm{c}^{\prime}} K_{1} \mathrm{P}_{\mathrm{O}_{2}}^{1 / 2} \mathrm{P}_{\mathrm{CO}_{2}}^{-1} \exp \left[\frac{-\beta_{2} F}{\mathrm{RT}} \mathrm{V}\right]
$$

Ai equilibriun.

$$
i=0 \text { and } l^{\prime}=V_{i}
$$

àb

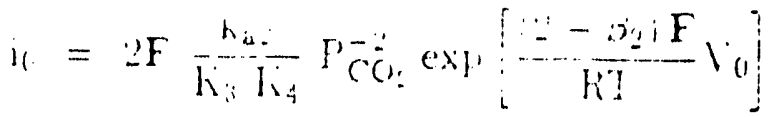

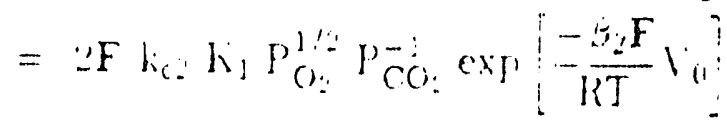


Lising Eqns. (123) and $(124)$.

$$
v_{0}=\frac{\mathrm{RT}}{2 \mathrm{~F}} \ln \left(\prod_{i=1}^{4} \mathrm{~K}_{\mathrm{i}} \mathrm{P}_{\mathrm{O}_{2}}^{1 / 2} \mathrm{P}_{\mathrm{CO}_{2}}\right)
$$

Substituting Eqn. [127] into Eqn. [125],

$$
i_{0}=2 \mathrm{~F} \frac{k_{\mathrm{a} 2}}{\mathrm{~K}_{3} \mathrm{~K}_{4}} \prod_{i=1}^{4} \mathrm{~K}_{\mathrm{i}}^{\left(2-\beta_{2}\right) / 2} \mathrm{P}_{\mathrm{O}_{2}}^{\left(2-\beta_{2}\right) / 4} \mathrm{P}_{\mathrm{CO}_{2}}^{-\left(2+\beta_{2}\right) / 2}
$$

Eqn. [128] can be also derived by substituting Eqn. [127] into Eqn. [126]. The exchange current density can be given as a function of $\mathrm{P}_{\mathrm{O}_{2}}$ and $\mathrm{P}_{\mathrm{CO}_{2}}$ :

$$
i_{0}=i_{0}^{0} \mathrm{P}_{\mathrm{O}_{2}}^{\mathrm{a}} \mathrm{P}_{\mathrm{CO}_{2}}^{\mathrm{b}}
$$

where, $\mathrm{i}_{0}^{0}$ is a temperature-dependent kinetic parameter, $\mathrm{a}$ is a reaction order for $\mathrm{PO}_{2}$. and $b$ is a reaction order for $\mathrm{PCO}_{2}$. Comparison of Eqns. [128] and [129] provides the expressions for the reaction orders:

$$
\mathrm{a}=\frac{2-\beta_{2}}{4} \text { and } \mathrm{b}=-\frac{2+\beta_{2}}{2}
$$

Substitution of Eqns. [118], [125], [126], and [127] into [123] and comparison with Eqn. [117] provide the Iransfer coefficients:

$$
a_{\dot{a}}=2-\beta_{2} \text { and } a_{c}=\beta_{2}
$$

\section{Rate Determining Siep : Eqn. [107:}

Ian. $\quad 105 j$ ! $106 \%$ and 1108 are in quasi-equilibrium. hence $r_{1} .1 \%$ and $r_{4}$ are

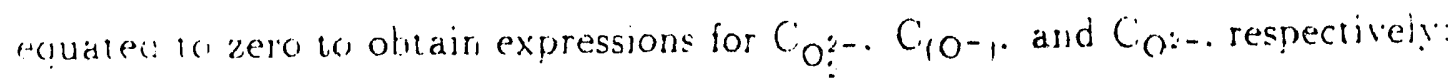

$$
\begin{aligned}
& c_{c:-}=K, \mathrm{P}_{0}^{1 /-} \mathrm{I}^{1-1} \mathrm{CO}
\end{aligned}
$$

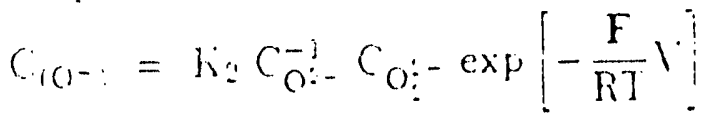

$$
\begin{aligned}
& C_{O-2}=\frac{i}{K_{i}} P_{C O}^{-1}
\end{aligned}
$$


Substitute Eqns. (116j and [132]-[134\} 1111/114] 1.0 obtain

$$
\begin{aligned}
\frac{i}{2 F}= & k_{\mathrm{a} 3} \exp \left[\frac{\left(1-\beta_{3}\right)}{\mathrm{RT}} \backslash\right] \\
& -k_{\mathrm{c} 3} k_{1} k_{2} k_{4} I_{1}^{\prime \prime} \mathrm{P}^{\prime} \mathrm{CO}_{2} \exp \left[\frac{-\left(1+\beta_{2}\right) \mathrm{F}}{\mathrm{RT}} \mathrm{V}\right] .
\end{aligned}
$$

At equilibrium,

$$
i=0 \text { and } V=V_{0}
$$

and

$$
\begin{aligned}
i_{0} & =2 F k_{\mathrm{a} 3} \exp \left[\frac{\left(1-\beta_{3}\right) F}{\mathrm{RT}^{\prime}} \mathrm{V}_{0}\right] \\
& =2 F \mathrm{k}_{\mathrm{c} 3} \mathrm{~K}_{1} \mathrm{~K}_{2} \mathrm{~K}_{4} \mathrm{P}_{()^{\prime:}}^{1 / 2} \mathrm{PCO}_{\mathrm{CO}_{2}} \exp \left[-\frac{\left(1+\beta_{3}\right) \mathbf{F}}{\mathrm{RT}} \mathrm{V}_{0}\right]
\end{aligned}
$$

Substituting [127] into Eqn. [137],

$$
i_{0}=2 \mathrm{~F} k_{\mathrm{a} 3} \prod_{i=1}^{4} \mathrm{~K}_{\mathrm{i}}^{\left(1-k_{3}\right) / 2} \mathrm{P}_{\mathrm{O}_{2}}^{\left(1-\beta_{3}\right) / 4} \mathrm{P}_{\mathrm{CO}_{2}}^{\left(1-\beta_{3}\right) / 2}
$$

As described earlier, expressions for the ruaction orders and the transfer coefficients are determined from Eqn. [139]:

$$
\begin{aligned}
& \mathrm{a}=\frac{1-\beta_{3}}{4} \text { and } \mathrm{b}=\frac{1-\beta_{3}}{2} \\
& a_{\mathrm{a}}=1-\beta_{3} \text { and } a_{\mathrm{c}}=1+\beta
\end{aligned}
$$

Kare Leremining Siep : Equ. [108]

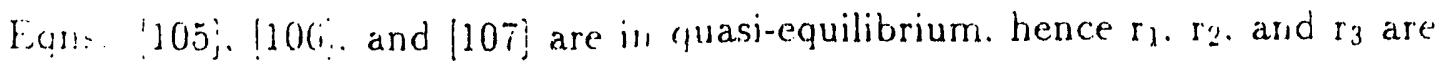

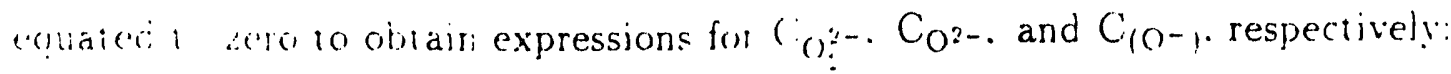

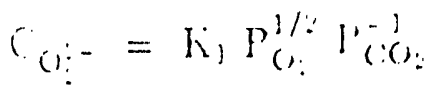

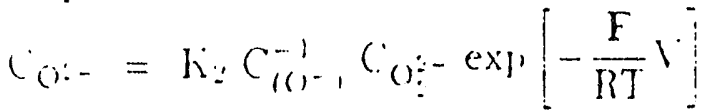

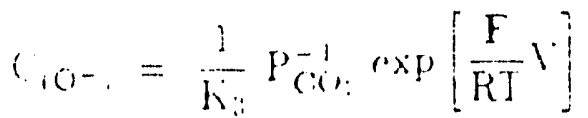


Substitute Eq11s. [116] and [142] ? 144? into [115] to ubtain

$$
\frac{i}{2 F}=k_{a 4}-k_{c 4} \prod_{i=1}^{3} k_{i} P_{O_{2}}^{1 / 2} P_{C O_{:}} \exp \left[-\frac{2 F}{R T} V\right]
$$

At equilibrium.

$$
i=0 \text { and } I^{\prime}=V_{0}
$$

and

$$
\begin{aligned}
\mathrm{i}_{0} & =2 \mathrm{~F} k_{\mathrm{a} 4} \\
& =2 \mathrm{~F} k_{\mathrm{c} 4} \prod_{\mathrm{i}=1}^{3} \mathrm{~K}_{\mathrm{i}} \mathrm{P}_{\mathrm{O}_{2}}^{1 / 2} \mathrm{P}_{\mathrm{CO}_{2}} \exp \left[-\frac{2 \mathrm{~F}}{\mathrm{RT}} \mathrm{V}_{0}\right]
\end{aligned}
$$

Substituting [127] into Eqn. [148],

$$
\mathrm{i}_{0}=2 \mathrm{~F} \mathrm{k}_{\mathrm{a} 4}
$$

As described earlier, expressions for the reaction orders and the transfer coefficients are determined from Eqn. [145]:

$$
\begin{gathered}
a=0 \text { and } b=0 \\
a_{a}=0 \text { and } a_{r}=2
\end{gathered}
$$

The similar procedure was used to determine the reaction orders and the transfer coefficients for the oxy'gen reduction mechanisms, involving superoxide and percarbonate ions. described below.

Superaxide Pati

$$
\begin{aligned}
& 3 / 4 \mathrm{O}_{2}+1 / 2 \mathrm{CO}_{3}^{2-}=\mathrm{O}_{z}^{-}+1 / 2 \mathrm{CO}_{2} \\
& \mathrm{O}_{2}^{-}+\mathrm{e}^{-}=\mathrm{O}^{:-} \\
& 0^{--}+0^{-}=10^{-},-()^{--} \\
& \mathrm{C}^{-}+\mathrm{CO}_{3}+\mathrm{t}^{-}=\mathrm{CO}_{3}^{--} \\
& \left(1:-+C O_{2}=\mathrm{CO}_{3-}^{-}\right.
\end{aligned}
$$

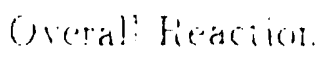




$$
344(1)-320:+3 e^{-}=3 / 2 \mathrm{CO}_{3}^{-}
$$

\section{Percarbonate Path}

$$
\begin{aligned}
1 / 2 \mathrm{O}_{2}+\mathrm{CO}_{3}^{2-} & =\mathrm{CO}_{4}^{2-} \\
\mathrm{CO}_{4}^{2-}+\mathrm{e}^{-} & =\mathrm{CO}_{3}^{2-}+\left(\mathrm{O}^{-}\right) \\
\left(\mathrm{O}^{-}\right)+\mathrm{e}^{-} & =\mathrm{C}^{2-} \\
\mathrm{O}^{2-}+\mathrm{CO}_{2} & =\mathrm{CO}_{3}^{2-}
\end{aligned}
$$

Overall Reaction

$$
1 / 2 \mathrm{O}_{2}+\mathrm{CO}_{2}+2 \mathrm{e}^{-}=\mathrm{CO}_{3}^{2-}
$$

The symmetry factor $\beta$ represents the fraclion of the applied potential which promules the cathodic reaction. lisually a value of $\beta$ lies between zero and one, and it has a value of 0.5 for a system which has symmetrical intersection in a "Morse Plot". The reaction orders and the transfer coefficients were calculated for $\beta$ equal to 0.5 and the values are given in Table 16 . 
Table 16. Theoretical Reaction Orders for the Exchange Current Density and the Transfer Coefficients for Oxygen Reduction Reaction.

\begin{tabular}{|c|c|c|c|c|c|}
\hline Mechanism & $\begin{array}{c}\text { Rate } \\
\text { Determining } \\
\text { step }\end{array}$ & $\mathrm{a}$ & $\mathrm{b}$ & $\alpha_{\mathrm{a}}$ & $\alpha_{\mathrm{c}}$ \\
\hline \multirow{3}{*}{ Peroxide } & $1 \mathrm{e}^{-}$ & 0.375 & -1.25 & 1.5 & 0.5 \\
& $2 \mathrm{e}^{-}$ & 0.125 & 0.25 & 0.5 & 1.5 \\
& Recomb. & 0.000 & 0.00 & 0.0 & 2.0 \\
\hline \multirow{3}{*}{ Superoxide } & $1 \mathrm{e}^{-}$ & 0.625 & -0.75 & 2.5 & 0.5 \\
& $2 \mathrm{e}^{-}$ & 0.375 & -1.25 & 1.5 & 1.5 \\
& $3 \mathrm{e}^{-}$ & 0.125 & 0.25 & 0.5 & 2.5 \\
& Recomb. & 0.000 & 0.00 & 0.0 & 3.0 \\
\hline \multirow{3}{*}{ Percarbonate } & $1 \mathrm{e}^{-}$ & 0.375 & -0.25 & 1.5 & 0.5 \\
& $2 \mathrm{e}^{-}$ & 0.125 & -0.75 & 0.5 & 1.5 \\
& Recomb. & 0.000 & 0.00 & 0.0 & 2.0 \\
\hline
\end{tabular}


Bhasker B. Davé was burn: :! iłar-Es-Salaam. Tanzania (East Africa), on Febr. 1961. to Bhagirath Prabtia-iraker and Triguna Laxmishanker Davé. He gra from Jawaharlal Nehru Hir: School at Surendranagar, India in May 197 attended M. P. Shah Art: : Sicience College (Saurashtra University, India) fro: to 1978. He attended Rerinal Engineering College, Tiruchchirapalli and $\mathrm{r}=$ Bachelor of Technolog! degree in Chemical Engineering (First Class with Disti= from University of Madras. India in August, 1983. He received Master of degree in Engineering from Southern Illinois University at Carbondale in Dec 1985. He married Sandra Maria Burke of Dublin, Ireland, on July 4. 1986.

The permanent mailing address for reaching $\mathrm{Mr}$. Davé is:

3. Vivekanand Society, Area-4

Surendranagar, Gujarat

India 363001 

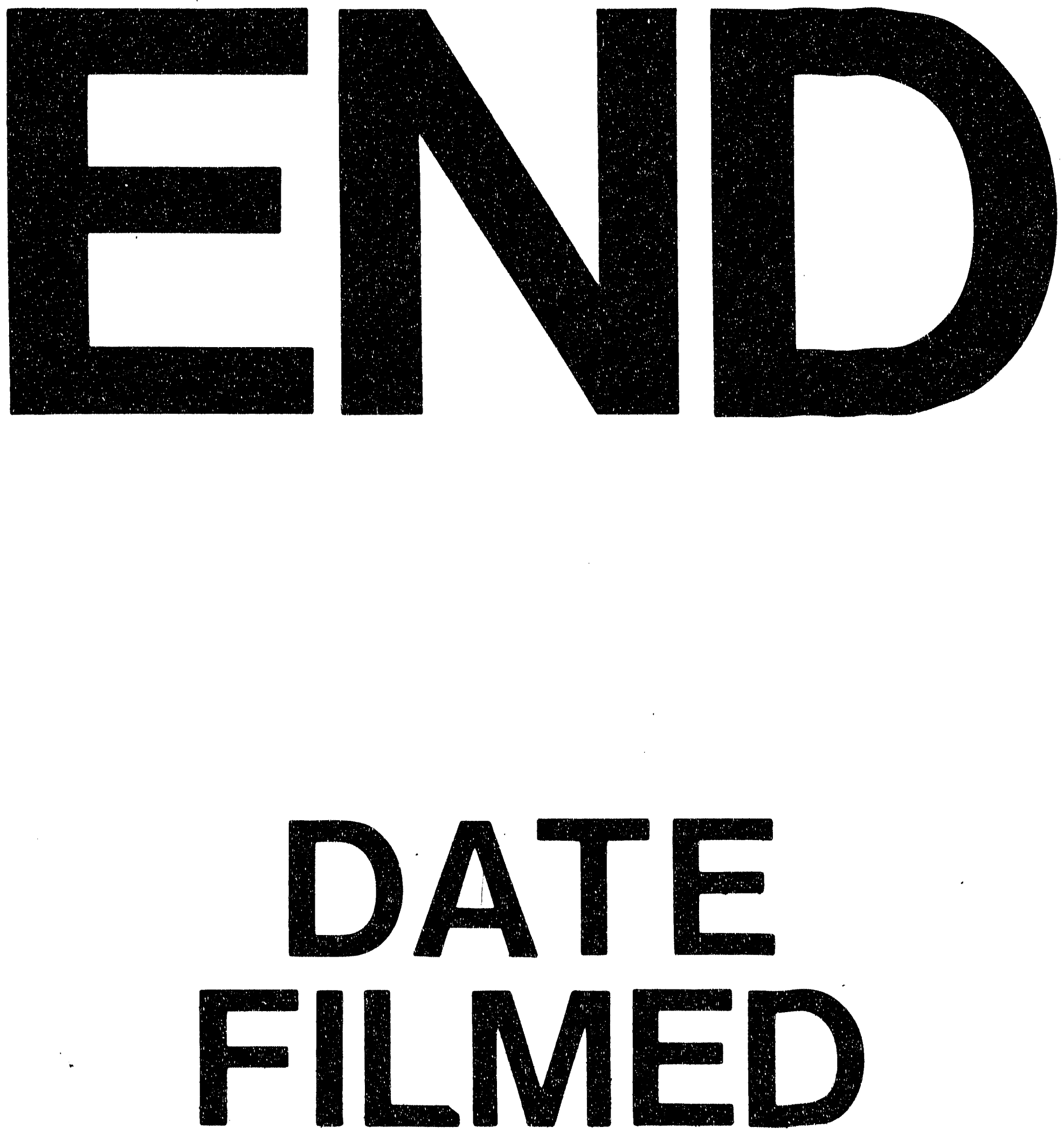

事

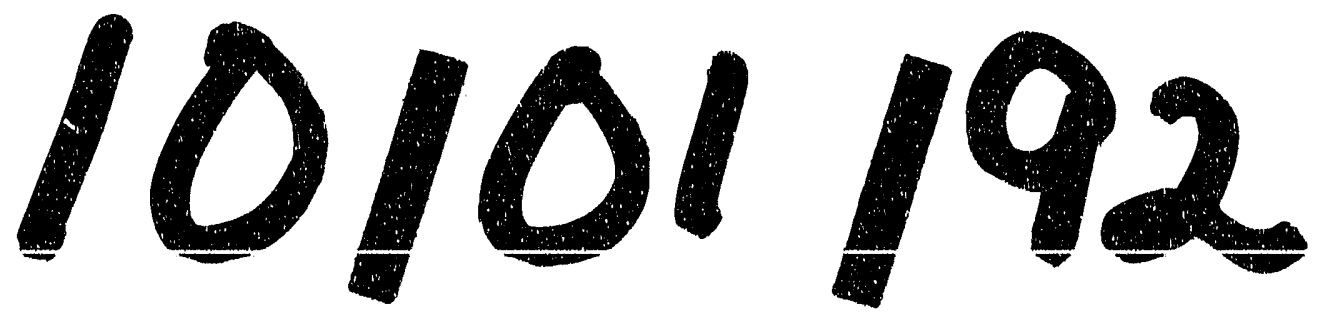


